\title{
MŁODZIEŻ I JEJ ŚWIAT: PRACA, EKOLOGIA, WYCHOWANIE, MAŁŻEŃSTWO I RODZINA
}

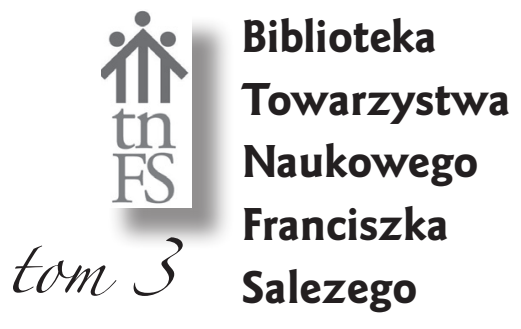




\section{Ryszard F. Sadowski SDB}

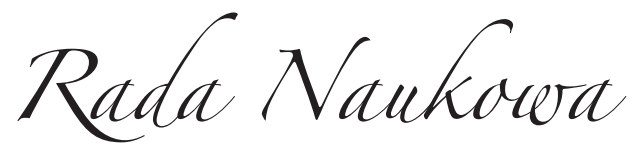

bp prof. dr hab. Andrzej F. Dziuba prof. dr hab. Jadwiga Kuczyńska-Kwapisz prof. dr Carlo Nanni SDB prof. dr hab. Michał Seweryński prof. dr hab. Henryk Skorowski SDB (przewodniczący) prof. dr hab. Marian Śnieżyński prof. dr hab. Stanisław Wilk SDB

T. 1

Wychowanie w stużbie praw czlowieka red. Jerzy Gocko SDB, Ryszard F. Sadowski SDB

T. 2

Młodzież w przestrzeni wolności.

W poszukiwaniu odpowiedzi na zmiany ustrojowe po roku 1989

red. Ryszard F. Sadowski SDB

Towarzystwo Naukowe Franciszka Salezego

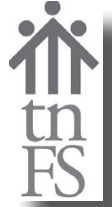

skr. poczt. 26; 05-092 Łomianki

tel. (22) 73273 80; e-mail: tnfs@tnfs.pl

www.tnfs.pl 


\section{MtODZIEŻ I JEJ ŚWIAT: PRACA, EKOLOGIA, WYCHOWANIE, MAtŻEŃSTWO I RODZINA}

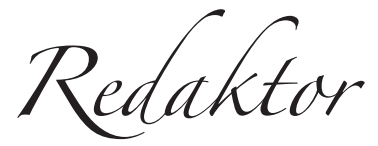

Jan Niewęgłowski SDB

Towarzystwo Naukowe Franciszka Salezego Warszawa 2017 


\section{Recensie wydawnice}

ks. prof. dr hab. Kazimierz Misiaszek SDB

ks. prof. UPJPII dr hab. Janusz Mączka SDB

Korekta edytorska

Joanna Wójcik

Projekt oktadki

Magdalena Joanna Chudzicka

Opracowanie Komputerowe
Marcin Izdebski

(c) Copyright by TNFS, Warszawa 2017

\section{Mydarea}

Towarzystwo Naukowe Franciszka Salezego

skr. poczt. 26; 05-092 Łomianki

tel. 2273273 80; e-mail: tnfs@tnfs.pl

www.tnfs.pl

ISBN 978-83-61451-32-7

Druk i oprawa

Poligrafia Salezańska

30-318 Kraków, ul. Bałuckiego 8, tel./fax (012) 2528500 


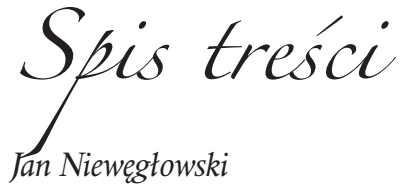

Wprowadzenie

MŁODZIEŻ I JEJ ŚWIAT: AKSJOLOGIA PRACY

Janusz Szulist

Kulturowa wartość pracy

13

Magda Urbańska

Społeczna wartość pracy

w kontekście pracy zawodowej

kobiet i mężczyzn

MŁODZIEŻ WOBEC WYZWAŃ EKOLOGICZNYCH

Dominika Dzwonkowska

Cnoty i wady środowiskowe

w edukacji ekologicznej

Anita Ganowicz-Baczyk

Spór o etykę środowiskową

i jego znaczenie dla edukacji

ekologicznej

61

Ryszard Sadowski

Ekofilozoficzne elementy

chrześcijańskiej promocji życia

79

\section{System WychowaWczy ŚW. Jana Bosko}

Jan Piskurewicz

Kształtowanie się systemu

prewencyjnego w okresie

działalności Jana Bosco - kontekst

społeczny i polityczny 
Zenon Latawiec

Jan Niewegłowski
Aktualność systemu prewencyjnego św. Jana Bosko w szkołach salezjańskich 111

Teologiczno-pedagogiczne

uwarunkowania sportu

salezjańskiego

\section{MŁODZIEŻ WOBEC MAŁŻEŃSTWA I RODZINY}

Henryk Stawniak

Magda Urbańska

Stanistaw Wilk
Małżeństwo w nauczaniu papieża Franciszka - aspekt kanoniczny 131

Preferowany model rodziny w opiniach młodzieży 151

Kard. August Hlond wobec zagrożeń małżeństwa i rodziny 167 


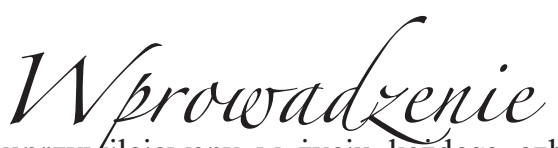

Młodość to czas uprzyy filejowany w życiu kazdego człowieka i zarazem wielkie jego bogactwo. W tym okresie człowiek odkrywa własne ja, własne zdolności i możliwości w nim tkwiące. Odkrywa ponadto ważny fakt, że jest jednostką jedyną i niepowtarzalną w istnieniu. Bogactwo młodości przejawia się również w odkrywaniu nowych rzeczy, dokonywaniu wyborów i podejmowaniu ważkich decyzji niekiedy na całe życie. Jan Paweł II w Liście do młodych pisze: „człowiek jest podstawową i zarazem codzienną drogą Kościoła, zatem pozostaje sprawą zrozumiałą, iż Kościół przywiązuje szczególną wagę do okresu młodości jako kluczowego etapu życia każdego człowieka”.

Młody człowiek ma przed sobą bogatą i wielobarwną przyszłość, która jednak związana jest z konsekwencjami jego wyborów. Dzięki wielkiemu rozwojowi nauki i odkryciom naukowym współczesne społeczeństwa dysponują licznymi środkami ułatwiającymi poznanie rzeczywistości i jej przekształcanie. Prowadząc młodego człowieka do takiego świata, nie można jednak odwoływać się do niepewnych i niebezpiecznych złudzeń. Zmiany po 1989 roku sprawiły, że polskie społeczeństwo znalazło się w totalnie nowej rzeczywistości. Pojawiły się nowe wyzwania i zadania intelektualne, społeczne, moralne, ekonomiczne, kulturalne i wychowawcze. Z łatwością stwierdzamy fakt, że po upływie prawie trzech dekad odczuwamy wciąż poważne problemy $\mathrm{z}$ ich rozwiązywaniem.

Na życie każdego człowieka, a zwłaszcza młodego, ma wpływ kultura, którą buduje współczesne społeczeństwo. Coraz częściej staje się ona kulturą grup i jednostek, które realizują jedynie własne interesy. Używając 
przy tym różnorodnych metod i narzędzi nie baczą, że stoją one bardzo często w sprzeczności z dobrem wspólnym. Kultura współczesna wydaje się zaspokajać potrzeby odczuwalne tu i teraz, czyli „mieć” nad „być”. Współczesny człowiek staje wobec dylematu wyboru. I wybór ten często jest niewłaściwy. Wobec takiej rzeczywistości staje również młody człowiek. Obecna rzeczywistość pozbawiona jest coraz częściej historii tradycji i zdrowych relacji rodzinnych; wspólnotę zbudowaną na właściwych relacjach osobowych, zajmuje zbiór anonimowych jednostek, które zajęte są sobą i realizacją własnych marzeń i celów. W tak rozumianej rzeczywistości nie ma celów wykraczających poza nasze ziemskie życie. Ich miejsce zajęły cele utylitarystyczne, pragmatyczne i nie rzadko hedonistyczne.

Jan Paweł II nazywał młodzież „najdroższą cząstką społeczeństwa” i widział w niej symbol przyszłości. Przyszłość świata i każdej społeczności związany jest ściśle z życiem człowieka i jego humanizmem. Rzeczy właściwie układają się, gdy uznaje on i uwzględnia wartość i znaczenie osoby. Aby tak było, należy w centrum formacji młodzieży postawić Prawdę. Jej obecność natomiast wskaże na głęboki sens poszczególnym momentom w życiu człowieka. Do nich zaliczamy narodziny, pracę, cierpienie, śmierć, religię. W takiej optyce należy postrzegać rolę i odpowiedzialność osób dorosłych w procesie wychowania i towarzyszenia młodemu człowiekowi. Wychowanie to proces bardzo długi, złożony i wymagający dużego zaangażowania ze strony rodziców, nauczycieli i wychowawców. Powinni oni z dużym ładunkiem wiary i nadziei kształtować w młodym człowieku osobowość dojrzałą i odpowiedzialną. Głównym zadaniem osób dorosłych jest wytrwałe, cierpliwe i nieustanne towarzyszenie młodemu pokoleniu, zwłaszcza wtedy, kiedy młody człowiek potrzebuje przewodnika i prawdziwego przyjaciela. Dyskretna, ale autentyczna obecność, ułatwi mu zająć właściwą postawę w życiu społecznym i wskaże mu wartości, na których ma budować swoją egzystencję.

Święty Jan Bosko (1815-1888), był turyńskim księdzem, który poświęcił całe swoje życie młodzieży biednej, potrzebującej i przez wszystkich opuszczonej. Swoim wychowankom dawał nie tylko chleb i dach nad głową, ale przede wszystkim wykształcenie. Działał w bardzo trudnym okresie historii Piemontu i Włoch. Były to czasy wojen, złożonych przemian politycznych, kulturowych i społecznych, ruchów rewolucyjnych, masowej migracji ludności wiejskiej do miast za chlebem. Wydarzenia te odcisnęły bolesne znamiona na życiu warstw najuboższych. Liczni ubo- 
dzy, a zwłaszcza ludzie młodzi, stłoczeni na peryferiach miast stawali się przedmiotem wyzysku, ofiarami bezrobocia i przestępczego życia. Ludzie młodzi wrażliwi na wszelkie przemiany, czuli się tym bardziej zagubieni i niepewni. Wobec tych potrzeb nie wystarczał tradycyjny model pracy z młodzieżą. Ksiądz Jan Bosko, wspierany przez innych filantropów, rzucił wyzwanie nowym potrzebom. Jego chrześcijańska inspiracja, odważne i roztropne inicjatywy, szybki i prężny rozwój dzieł, zmieniły diametralnie sytuację piemonckiej młodzieży. Natomiast jego autentyczne zaangażowanie i długoletnie doświadczenie pracy z młodzieżą umożliwiło mu stworzenie niepowtarzalnego stylu odwołującego się do rozumu, religii, dobroci, dialogu, klimatu rodzinnego, obecności wśród wychowanków i kształtowaniu w wychowankach wyższych wartości. Tradycja nazwała powyższą metodę systemem prewencyjnym.

Sto lat po śmierci ks. Jana Bosko, sytuacja młodzieży w dzisiejszym świecie zmieniła się w sposób znaczący. Pomimo licznych osiągnięć na wielu płaszczyznach, także dzisiaj pozostają aktualne te problemy, którymi żył dziewiętnastowieczny Turyn, a ks. Jan Bosko próbował zrozumieć i rozwiązać. Kim jest młody człowiek? Do czego dąży? Jakie ma potrzeby? Są to problemy, jak zawsze trudne, lecz nieuniknione, którym rodzic, nauczyciel czy wychowawca musi stawić czoło. $Z$ jednej strony należy również pamiętać, że wśród dzisiejszej młodzieży nie brak wrażliwych osób na duchowe wartości, poszukujących pomocy i wsparcia w procesie formowania ich osobowości. Z drugiej strony zauważamy, że najczęściej młode pokolenie jest narażone na negatywne oddziaływania poglądów ideologicznych. Roztropny wychowawca winien studiować $\mathrm{z}$ uwagą sytuację młodzieży i reagować z niezawodną kompetencją.

Prezentowana publikacja, ukazująca się jako trzeci tom serii „Biblioteki Towarzystwa Naukowego Franciszka Salezego", zostanie wydana pod auspicjami Towarzystwa Naukowego Franciszka Salezego. Niniejszy tom podejmuje w sposób szczególny próbę ukazania rzeczywistości współczesnej młodzieży polskiej na czterech obszarach: nowe ujęcie pracy, znaczenie ekologii, aktualność wychowawczego systemu ks. Jana Bosko, miejsce i rola małżeństwa i rodziny $\mathrm{w}$ XXI wieku. Czyni to z różnych punktów widzenia. Jest więc obecna pedagogika, socjologia, psychologia, historia, katolicka nauka społeczna, teologia, prawo. Na interesujące tematy dotyczące sytuacji młodzieży wypowiadają się badacze reprezentujący różne dyscypliny i środowiska naukowe. Bez wątpienia wszystkim leży na sercu 
dobro i przyszłość polskiego młodego pokolenia. Można mieć nadzieję, że niniejsza publikacja będzie pomocną i przydatną w kontynuacji kolejnych poszukiwań naukowych na tych płaszczyznach.

Publikacja podzielona jest na cztery części. W pierwszej części noszącej tytuł „Młodzież i jej świat: aksjologia pracy” zaprezentowano dwa rozdziały. Ukazują one personalistyczny charakter pracy w perspektywie Katolickiej Nauki Społecznej oraz społeczną wartość pracy w kontekście pracy zawodowej kobiet i mężczyzn. Praca zawodowa jest jedną z istotnych wartości uznawanych przez Polaków i najważniejszym komponentem udanego i szczęśliwego życia. Część druga „Młodzież wobec wyzwań ekologicznych" zawiera trzy rozdziały. Prezentują one cnoty i wady człowieka w etyce cnót środowiskowych, które mogą z kolei stać się narzędziem ochrony albo destrukcji środowiska naturalnego. Mogą one również stać się pewnym wskazaniem dla edukacji ekologicznej, której celem jest ukształtowanie właściwego systemu wartości dla relacji człowieka z przyrodą. Ostatnim zagadnieniem tej części są ekofilozoficzne elementy chrześcijańskiej promocji życia. Stosunkowa młoda dyscyplina filozoficzna poszukuje odpowiedzi na pytanie o wartość przyrody pozaludzkiej, na zrozumienie współczesnych wyzwań ekologicznych, a także zajmuje się problematyką degradacji środowiska naturalnego, szybkiego wymierania gatunków, rosnącej populacji ludzkiej czy konsumpcyjnego stylu życia współczesnego społeczeństwa.

Na trzecią część publikacji zatytułowaną „System wychowawczy św. Jana Bosko" składają również trzy rozdziały. Pierwszy stara się przybliżyć czytelnikowi proces kształtowania się systemu prewencyjnego, który dokonywał się w długiej działalności wychowawczej ks. Jana Bosko. Analiza pedagogiczna uwzględnia realia społeczne i polityczne tamtego okresu i ich wpływ na taką, a nie inną formę propozycji wychowawczej ks. Jana Bosko. Rozdział drugi ukazuje systemy prewencyjny w rzeczywistości polskiej i we współczesnym szkolnictwie salezjańskim. Wydaje się, że metoda opracowana w połowie XIX w. nie tylko się nie zdezaktualizowała, ale wciąż może stanowić żywy wzorzec wychowania młodzieży, szczególnie w dzisiejszych czasach kryzysu wartości i autorytetów. Jednym z ważnych elementów tego systemu jest sport. Trzeci rozdział jest próbą ukazania sportu i jego znaczenia w systemie wychowawczym ks. Bosko. Wychowawca turyński jako baczny obserwator życia społecznego, a szczególnie życia młodego człowieka w czasach wielkiego kryzysu przejawiającego się w postaci ubóstwa materialnego, duchowego, kradzieży, bandytyzmu, prostytucji i in- 
nych, uznał że jest on ważny w pracy z młodzieżą jako środek, który może odegrać ważną rolę w procesie wychowania i służyć holistycznemu rozwojowi młodego człowieka i jego dobru.

Czwarta część książki „Młodzież wobec małżeństwa i rodziny” zawiera trzy rozdziały. Pierwszy z nich przedstawia małżeństwo w aspekcie prawa kanonicznego oraz w nauczaniu papieża Franciszka. Papież odwołując się do nauczania Jana Pawła II w tym zakresie oraz wystąpienia kardynała Waltera Kaspera na Konsystorzu Kardynałów w 2014 roku, opowiada się za nierozerwalnością małżeństwa. Nauczanie papieskie o małżeństwie porusza również trudną problematykę związków «nieregularnych» w perspektywie włączenia ich we wspólnotę Kościoła. Uzupełnieniem powyższego zagadnienia jest rozdział następny mówiący o preferowanych modelach rodziny w opiniach współczesnej młodzieży. Szybkie przemiany kulturowe dokonujące się we współczesnym świecie rzutują również na rodzinę. Do niedawna podstawą rodziny było małżeństwo, dzisiaj coraz częściej, pojawiają się obok rodziny nuklearnej, różnorodne formy życia małżeńskiego i rodzinnego. Coraz częściej związki te nie są formalizowane, a kohabitacja staje się formą alternatywną dla tradycyjnie rozumianego małżeństwa. Ponadto wzrasta liczba rozwodów i rodziców samotnie wychowujących potomstwo. Zmienia się model życia rodzinnego, który stara się dopasować do indywidulanych potrzeb i oczekiwań jednostek. Publikację zamyka przywołana nauka kardynała Augusta Hlonda na temat małżeństwa i rodziny. Prymas Polski poświęcał tej instytucji bardzo wiele miejsca i czasu w swojej pracy duszpasterskiej, jak również w nauczaniu. Dzisiejsza Europa staje wobec lawiny nowych wyzwań takich jak: szybki proces starzenia się, laicyzacja, wprowadzanie do państwowych nowych systemów prawnych kolejnych przepisów i norm, które burzą tradycyjne pojęcie i funkcje małżeństwa i rodziny, wzrastająca liczba rozwodów oraz rodzin nie posiadających dzieci. Wydaje się, że nauka kardynała August Hlonda podkreślająca sakramentalny charakter małżeństwa i jego wielkie znaczenie dla życia społecznego, może stanowić punkt odniesienia dla dzisiejszych małżeństw i rodzin.

Jan Niewęgłowski 


\section{ks. Janusz Syulist}

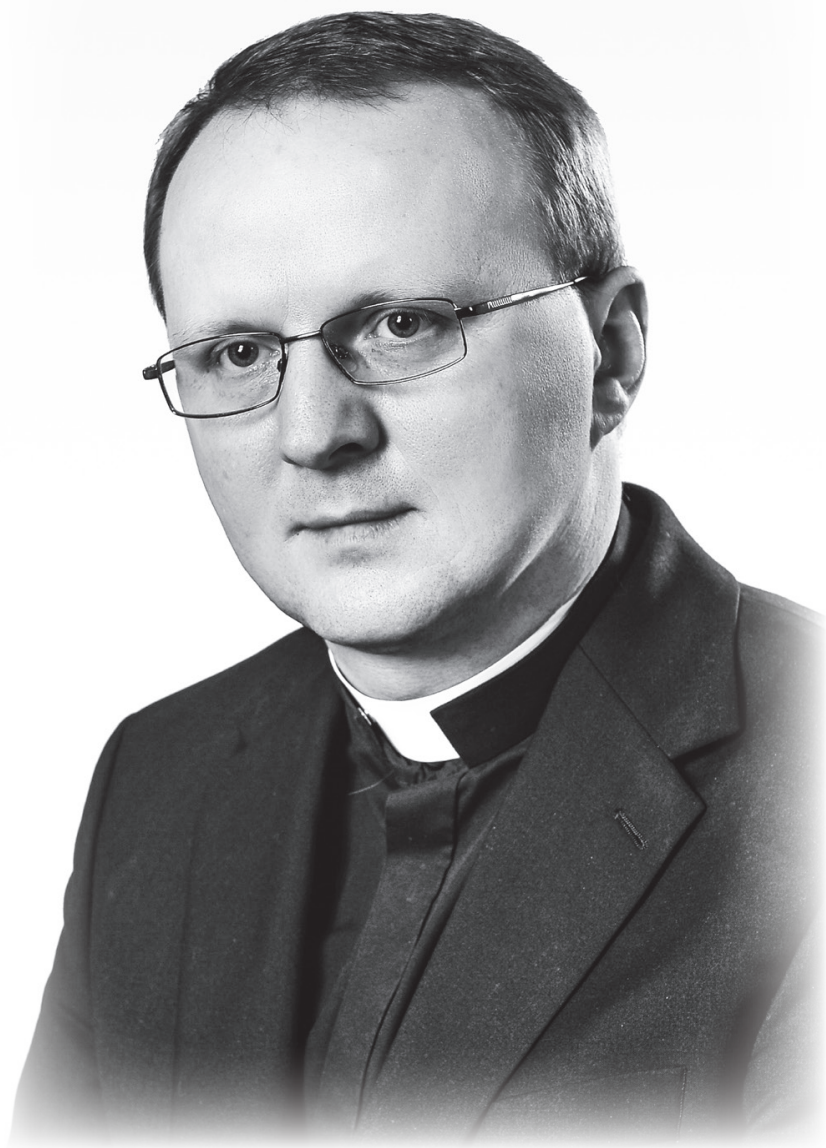

Ks. Janusz Szulist (ur. 1973 r.) doktor habilitowany nauk teologicznych w zakresie katolickiej nauki społecznej.

Profesor Uniwersytetu Mikołaja Kopernika w Toruniu.

Adiunkt Katedry Pedagogiki,

Katolickiej Nauki Społecznej

i Prawa Kanonicznego Wydziału Teologicznego Uniwersytetu

Mikołaja Kopernika w Toruniu. 


\section{Kulturowa wartość pracy}

Wstęp

Kompendium nauki społecznej Kościoła w następujący sposób wyraża personalistyczny charakter pracy: „Praca jest podstawowym prawem i dobrem człowieka: dobrem pożytecznym, godnym człowieka, ponieważ odpowiednim właśnie do wyrażania i pomnażania ludzkiej godności"1. Godności człowieka nie można zatem zakrywać, alienować, a tym bardziej kwestionować. Powinno się natomiast czynić z niej wartość, która nie tylko nadaje charakter ludzkim działaniom, ale poprzez dzieła osoby aktywnie wpływa na jego środowisko. W wyniku poszerzania znaczenia elementów natury osobowej człowiek staje się bardziej wartościowy, a otaczający go świat, uporządkowany według kryterium personalistycznego, zyskuje status narzędzia szerzenia modelu kultury przyporządkowanej dobru ludzkości. Można zatem wskazać na dwie prawidłowości: 1. kultura stanowi bezpośrednią konsekwencję pracy ludzkiej; 2. zarówno praca, jak i kultura służą wyrażaniu dobra osobowego.

Materiał źródłowy niniejszej publikacji stanowią dokumenty nauczania społecznego Kościoła, a także publikacje z zakresu etyki społecznej. Zaprezentowane wnioski zostały sformułowane na podstawie analizy tychże tekstów. Publikacja jest podzielona na trzy części. Pierwsza z nich dotyczy istotowej zależności pomiędzy pracą a kulturą na poziomie określeń zawartych w nauczaniu społecznym Kościoła. Treść drugiej części stanowi zagadnienie personalistycznego charakteru pracy, dotyczące w równym stopniu podmiotowego i przedmiotowego aspektu działalności zawodowej oraz otwarcia człowieka na osobowo pojmowanego Boga. Trzecia, ostatnia

\footnotetext{
1 Kompendium nauki społecznej Kościoła, red. Papieska Rada „Iustitia et Pax”, Wydawnic-
} two „Jedność”, Kielce 2005, 287 [dalej: KNSK]. 
część zawiera omówienie problemu treści kultury przynależących do istoty pracy człowieka.

\section{Istotowa zależność kultury i pracy}

Jednym z założeń nauczania społecznego Kościoła jest istotowa zależność kultury i pracy. Ojcowie soborowi w Konstytucji duszpasterskiej o Kościele w świecie wspótczesnym „Gaudium et spes” następująco określają sens zjawiska kultury: „Słowem kultura w znaczeniu ogólnym określa się wszystko, za pomocą czego człowiek doskonali i rozwija różnorodne dary ducha i ciała, usiłuje dzięki poznaniu i pracy podporządkować swojej władzy świat, zaś przez postęp obyczajów i różnych instytucji czyni bardziej ludzkim życie społeczne zarówno w rodzinie, jak i w całej społeczności obywatelskiej, a na przestrzeni dziejów wyraża, przekazuje i zachowuje w swoich dziełach wielkie doświadczenia duchowe i pragnienia po to, by służyły rozwojowi wielu, a nawet całego rodzaju ludzkiego" ${ }^{2}$. Kultura stanowi powszechne zjawisko, którego wyznacznikiem jest dobro osoby. $Z$ tego względu Ojcowie soborowi stwierdzają, iż za pośrednictwem kultury jednostka odkrywa swoje człowieczeństwo i jednocześnie wzmacnia proces transponowania do świata dóbr o charakterze osobowym ${ }^{3}$. Czynnikiem sprzyjającym rozwojowi kultury jest praca, która została w następujący sposób określona przez św. Jana Pawła II w encyklice Laborem exercens: „[...] praca zaś oznacza każdą działalność, jaką człowiek spełnia, bez względu na jej charakter i okoliczności, to znaczy każdą działalność człowieka, którą za pracę uznać można i uznać należy pośród całego bogactwa czynności, do jakich jest zdolny i dysponowany poprzez samą swoją naturę, poprzez samo człowieczeństwo"4. Praca w koncepcji papieskiej stanowi sposób bytowania człowieka, wykraczający poza sferę regulowania potrzeb egzystencjalnych mającego na celu zachowanie przy życiu gatunku ludzkiego. Zakres transcendencji realizowanej w ramach pracy wyznacza jej charakter osobowy.

Zbieżność pojęć w zakresie kultury i pracy jest wyznaczana szczególnie przez dwa określenia: godność osobowa jako istota człowieczeństwa

\footnotetext{
2 Sobór Watykański II, Konstytucja duszpasterska o Kościele w świecie współczesnym „Gaudium et spes”, w: Sobór Watykański II, Konstytucje. Dekrety. Deklaracje. Tekst Polski. Nowe Tłumaczenie, Pallottinum, Poznań 2002, 53 [dalej: KDK].

3 Por. tamże.

4 Jan Paweł II, Encyklika „Laborem exercens” (14 września 1981), wstęp [dalej: LE].
} 
oraz działanie. Analiza godności osobowej na podstawie danych Objawienia, jak też w perspektywie filozofii personalistycznej, pozwala wyodrębnić dwa wymiary omawianego czynnika. Po pierwsze, należy wyróżnić tzw. godność naturalną, na którą składają się takie elementy, jak samoświadomość, wolność, kognitywność, wolitywność oraz wyróżnienie przez Boga spośród innych stworzeń. Drugi wymiar godności stanowi godność nadprzyrodzona, dotycząca relacji człowieka z Bogiem. Ludzie stają się godni, by być adresatami, czyli odbiorcami Bożych darów. Ponadto Bóg jednoczy się w Chrystusie z każdym człowiekiem, ubogacając tym samym w sposób nieskończony ludzką naturę 5 .

Poprzez działanie osoba ludzka wyraża własną indywidualność. Karol Wojtyła pisał:

„[...] będąc sprawcą czynu, człowiek równocześnie spełnia w nim siebie”6. Przenosząc powyższą zależność w rzeczywistość pracy, należy stwierdzić w pierwszej kolejności wyjątkowość tego typu działalności. Również w toku pracy człowiek wyciska piętno na owocach swoich czynów

Zarówno praca, jak i kultura są dobre same w sobie, jednakże nie można przypisać im przymiotu absolutności. Odnosząc się w tym momencie rozważań do interpretacji prawa do pracy - per analogiam również do prawa do bycia twórcą i odbiorcą kultury - należy wyróżnić dwa ograniczenia działalności ludzkiej. Pierwszym z nich jest zasada racjonalności. Nie można bowiem nazwać pracą działania bezrozumnego, sprzecznego z postulatami sfery ratio. Drugie ograniczenie stanowi dobro wspólne. Nie jest pracą postępowanie, które koliduje z dobrem wspólnym i jest skierowane przeciwko bliźnim, a w efekcie także przeciwko osobie działającego. Dobro wspólne w istocie posiada bowiem charakter personalistyczny ${ }^{8}$.

W ramach krótkiego podsumowania pierwszej części rozważań należy wskazać na dwa wnioski. Po pierwsze, człowiek kulturalny jest jed-

5 Por. J. Kupny, Podstawowe zasady życia społecznego, w: Katolicka nauka społeczna. Podstawowe zagadnienia z życia społecznego i politycznego, red. S. Fel, J. Kupny, Księgarnia św. Jacka, Katowice 2007, s. 80-81.

${ }^{6}$ K. Wojtyła, Osoba i czyn, Polskie Towarzystwo Teologiczne, Kraków 1985, s. 185.

7 Por. KDK 67. W tejże części dokumentu Ojcowie soborowi charakteryzują niektóre zasady życia społeczno-gospodarczego.

8 Por. J. Majka, Rozważania o etyce pracy, Wydawnictwo Wrocławskiej Księgarni Archidiecezjalnej, Wrocław 1986, s. 157-158. 
nocześnie pracowity. Powyższa zasada obowiązuje również w odniesieniu do form odpoczynku przy założeniu, że czas wolny stanowi konsekwencję okresu pracy (por. Rdz 2,2). Druga prawda dotyczy kwestii kompleksowości. Zarówno kultura, jak i praca posiadają znamiona integralności, a więc podobnie jak byt osobowy - obejmują elementy natury materialno-duchowej.

\section{Personalistyczny charakter pracy}

Wartość działania człowieka wynika z godności osobowej, a więc z podobieństwa do Boga. Godność człowieka dotyczy także aktywności zawodowych i pracy w ogólności. Ów prymat osoby wyznacza istotę pracy $\mathrm{i}$ jest ujmowany $\mathrm{w}$ aspekcie podmiotowym oraz przedmiotowym. Również człowiek pracujący pozostaje w naturalny sposób otwarty na Boga, co potwierdzają dane Objawienia, a w szczególności stworzenie i odkupienie. W Bogu bowiem osoba ludzka znajduje źródło motywacji. Za sprawą naśladowania Jezusa akty jej autorstwa zyskują walor świętości.

\subsection{Praca w aspekcie podmiotowym i przedmiotowym}

Ogólny charakter określeń kultury i pracy, przedstawiony powyżej, stanowi fundament analizy specyfiki zagadnienia pracy w kontekście wielorakich aktywności człowieka w świecie. Ów wyjątkowy charakter ludzkich działań znajduje wyraz w definicjach szczegółowych pracy, obecnych w refleksji różnych autorów: poprzez pracę realizowany jest udział w procesie wytwórczym (M.-D. Chenu); praca sprzyja „tworzeniu wartości użytecznych społecznie, wartości duchowych i materialnych” (Cz. Strzeszewski); dzięki pracy świat jest w stanie regulować jak najpełniej ludzkie potrzeby (J. W. Gałkowski); praca stanowi wartość samą w sobie, umożliwiającą wymianę dóbr (KDK 67) ${ }^{9}$. Należy zatem stwierdzić, iż dzięki pracy człowiek wchodzi w relację ze światem. Ów proces jest realizowany za sprawą wytwarzania dóbr, wzrostu zdolności nabywczej i związanej z nim wymiany dóbr oraz zdobywanej możliwości zaspokajania potrzeb wynikających z natury jednostki i środowiska społecznego. We wszystkich wspomnianych definicjach pracy człowiek funkcjonuje jako autor aktów o niepodważalnym autorytecie pośród świata stworzeń. Sugerowana w tychże definicjach god-

9 Por. za: J. Gocko, Praca, w: Słownik społeczny, red. B. Szlachta, Wydawnictwo WAM, Kraków 2004, s. 943. 
ność pracy, będąca niezmiennym principium, przejawia się w podmiotowym i przedmiotowym charakterze aktywności pracowniczej. Podmiotowy aspekt pracy człowieka został następująco scharakteryzowany w encyklice Laborem exercens św. Jana Pawła II: „Człowiek dlatego ma czynić sobie ziemię poddaną, ma nad nią panować, ponieważ jako «obraz Boga» jest osobą, czyli bytem podmiotowym uzdolnionym do planowego i celowego działania, zdolnym do stanowienia o sobie i zmierzającym do spełnienia siebie. Jako osoba jest tedy człowiek podmiotem pracy"10. Aspekt podmiotowy określa jednocześnie personalistyczny charakter pracy. Praca stanowi działanie, poprzez które człowiek wyraża swoją wolność i rozumność. Aktywność zawodowa jest więc przestrzenią emanacji własności decydujących o byciu osobą. Pytanie o człowieka w świecie pracy ma zatem status pytania o niepodważalność czynnika osobowego $\mathrm{w}$ dziele produkcji ${ }^{11}$.

Drugi aspekt pracy nosi miano przedmiotowego. Oznacza on relację do świata w sensie porządkowania rzeczywistości stworzonej, przyjmując osobę ludzką za jedyny układ odniesienia. Współcześnie przedmiotowy charakter pracy dotyczy technologii, które powinny być wykorzystywane w służbie człowiekowi. Technika stanowi zapis dokonań ludzkości, a jej rozwój jest jednym z głównych czynników wyznaczających momenty przełomowe w dziejach cywilizacji. Technicyzacja świata nie może jednak nigdy przesłonić perspektywy ludzkiej, gdyż to właśnie technologia istnieje dla człowieka, a nie odwrotnie ${ }^{12}$. Podmiot funkcjonuje bowiem w relacji nadrzędności wobec przedmiotu. Działaniem nieludzkim i sprzecznym z naturą jest więc redukcja podmiotu do przedmiotu ${ }^{13}$.

Społeczny charakter pracy łączy w jedno podmiotowy i przedmiotowy aspekt zaangażowania człowieka. Współczesny robotnik funkcjonuje zwykle w systemach, w których działanie w pojedynkę byłoby skazane na niepowodzenie. Istnieje w ich ramach niemalże nakaz współdziałania, aby skutecznie i efektywnie produkować dobra oraz wypracowywać stosunkowo wysoki zysk. Nowoczesne technologie skłaniają człowieka do współdzia-

\footnotetext{
10 LE 6.

11 Por. J. Szulist, Perspektywy ludzkiego rozwoju. Kluczowe zagadnienia encykliki „Caritas in veritate", Bernardinum, Pelplin 2009, s. 71-71; T. Borutka, Wielowymiarowość ludzkiej pracy, w: Praca kluczem polityki społecznej. Materiały sympozjum w 25-lecie wydania encykliki „Laborem exercens" Jana Pawła II, reda. J. Towarzystwo Naukowe KUL, Mazur, Lublin 2007, s. 67; J. Gocko, Praca, dz. cyt., s. 949.

12 Por. LE 5; KNSK 270.

13 Zob. J. Gocko, Praca, dz. cyt., s. 949-950.
} 
łania w celu realizowania postulatów natury społecznej ${ }^{14}$. Otwartość na bliźnich kształtowana jest również w aspekcie charakteru własności. Otóż powszechne przeznaczenie dóbr jest bardziej pierwotną zasadą niż idea własności prywatnej. Tego typu zależność określa opis stworzenia pierwszych ludzi (por. Rdz 1,28-31). Hipoteka społeczna stanowi postulat, aby w sytuacji kryzysu czy niesprawiedliwości społecznej wykazać gotowość pomocy biedniejszym i znajdującym się we wcześniejszej fazie rozwoju cywilizacyjnego. Oferowana i przekazywana realnie pomoc kształtuje poczucie braterskiej więzi będącej bezpośrednią konsekwencją społecznej natury osoby ${ }^{15}$. Ostatni element społecznego charakteru pracującego podmiotu dotyczy zjednoczenia z innymi robotnikami. W tymże aspekcie kluczowe znaczenie ma przede wszystkim potrzeba wspólnej ochrony zagrożonych dóbr, realizowana w ramach działalności związkowej ${ }^{16}$. Istotne jest również współdziałanie na rzecz pogłębiania świadomości społecznej i wspólnotowego wkładu w dorobek kulturowy rodzaju ludzkiego ${ }^{17}$.

\subsection{Teologiczny aspekt pracy}

Praca określa sposób bytowania człowieka w tak wysokim stopniu, iż można ją charakteryzować w kategorii powołania. Jak podaje autor natchniony Księgi Rodzaju, człowiek został stworzony, by między innymi „czynić sobie ziemię poddaną” (por. Rdz 1,28). Osoba powinna zatem kształtować porządek stworzenia, aby ten jak najpełniej odpowiadał jej uwarunkowaniom ${ }^{18}$.

Realizacja powołania do pracy zachodzi wówczas, kiedy człowiek w praktyce czyni świat lepszym, to znaczy uświęca i doskonali rzeczywistość stworzoną. W ramach owego procesu oddziaływania na świat Bóg objawia się w dwojaki sposób. Po pierwsze, poprzez swoje czyny człowiek

14 Por. KNSK 273.

15 Zob. KDK 69; Jan Paweł II, Encyklika „Centesimus annus” (1 maja 1991), nr 31 [dalej: CA].

16 Por. LE 20.

17 Zob. tamże, nr 10; tenże, Adhortacja „Christifideles laici” (30 grudnia 1988), nr 44 [dalej: $\mathrm{ChL}$, za: S. Fel, Społeczno-etyczny wymiar pracy ludzkiej, w: Katolicka nauka społeczna. Podstawowe zagadnienia z życia gospodarczego, red. J. Kupny, S. Fel, Księgarnia św. Jacka, Katowice 2003, s. 33.

18 Por. S. Olejnik, Teologia moralna życia społecznego, Włocławskie Wydawnictwo Diecezjalne, Włocławek 2000, s. 435-436; T. Borutka, Wielowymiarowość ludzkiej pracy..., dz. cyt., s. 71. 
partycypuje w dziele kształtowania ładu Bożego. Pod drugie, Bóg nieustannie udziela swoich łask, które wpływają na skuteczność przemian realizowanych przez człowieka. Można zatem stwierdzić, iż zarówno osoba ludzka, jak i świat są otwarte na transcendencję. Zdolność współdziałania z Bogiem stanowi nie tylko postulat wynikający z natury, ale jest obowiązkiem mającym swoje źródło w powołaniu człowieka ${ }^{19}$.

Zapis stworzenia wskazuje również na genezę trudu związanego z wykonywaniem pracy (por. Rdz 3,17-19). Znój towarzyszący pracującemu człowiekowi w żadnym przypadku nie upoważnia do obarczania pracy mianem czynności przeklętej. Praca wiąże się wprawdzie z wyrzeczeniami, niemniej należy pamiętać, iż celem tychże wyrzeczeń jest doskonalenie ducha, nauka postawy ofiarności oraz opanowanie żądz i pokus drzemiących w człowieku ${ }^{20}$.

Zmysł sprawiedliwości, ukształtowany dzięki przestrzeganiu prawa Bożego, znajduje zastosowanie w relacjach typowych dla świata pracy. Wymogiem sprawiedliwości jest zatem nakaz płacy za wykonane dzieło (por. Kpł 19,13), zakaz wyzysku i okrucieństwa wobec pracujących (por. Wj 1,11.14), szacunek dla każdego człowieka pracującego, nawet niewolnika (por. Pwt 23,15-16;24,14) ${ }^{21}$, oraz kształtowanie instytucji zabezpieczenia społecznego wobec osób marginalizowanych (por. Pwt 15,4)22. Analiza danych Objawienia pozwala na stwierdzenie, iż wyznacznikiem stosowania zasad sprawiedliwości względem pracujących jest posiadana przez nich godność (por. Rdz 1,27) ${ }^{23}$. Wyróżnienie człowieka w akcie stworzenia stanowi wystarczającą przyczynę szczególnej troski ze strony Boga dotyczącej bezpośrednio ludzkiego jestestwa.

Teologiczny wymiar pracy jawi się w całej pełni w Nowym Testamencie, a ściślej w wydarzeniach paschalnych (por. Mt 26,1-28,20); w ich kontekście następuje reinterpretacja trudu związanego z pracą, będącego jak już zaznaczono powyżej - skutkiem grzechu. Za sprawą pracy człowiek

\footnotetext{
19 Por. Cz. Strzeszewski, Praca ludzka. Zagadnienie społeczno-moralne, Towarzystwo Naukowe KUL, Lublin 1978, s. 137-138.

20 Por. KNSK 256.

21 Por. Cz. Strzeszewski, Praca ludzka..., dz. cyt., s. 139-142.

22 Por. T. Borutka, Propedeutyka katolickiej nauki społecznej, w: T. Borutka, J. Mazur, A. Zwoliński, Katolicka nauka społeczna, Wydawnictwo Zakonu Paulinów „Paulinianum”, Częstochowa 1999, s. 33.

23 Por. KNSK 108.
} 
musi przezwyciężać swoje słabości, podejmować trud podporządkowania sobie przyrody i zmagać się z różnego rodzaju przeciwnościami. Wytrwanie w realizacji tego typu działań jest możliwe tylko i wyłącznie przy założeniu istnienia zasady ofiarności, która znajduje swój wzór w wydarzeniach Paschy. Św. Jan Paweł II akcentuje, iż dla człowieka pracującego absolutny punkt odniesienia stanowi ofiara Chrystusa. Naśladując Jezusa w znoszeniu cierpień i przezwyciężaniu śmierci, ludzie pracy dostrzegają w trudzie zawodowym drogę ku doskonałości chrześcijańskiej. Dążenie ku niej sprawia ponadto, że pracujący pogłębiają swoje uczestnictwo w Chrystusowym odkupieniu ${ }^{24}$.

Dane biblijne w kwestii pracy dowodzą, iż człowiek poprzez realizowane dzieła może współpracować z Bogiem. Owo współdziałanie jest nie tylko kontynuacją porządku stworzenia, ale przede wszystkim przyczynia się do budowania Królestwa Bożego, którego wyznacznik stanowi świętość wynikająca z nadprzyrodzonej miłości Boga i człowieka. Poprzez pracę wpisaną w kanon zasad moralnych - pochodzących z prawa Bożego - jest objawiana w świecie chwała Boża; ponadto rzeczywistość stworzona staje się lepiej przygotowana na powtórne przyjście Mesjasza i bardziej godna spotkania z Nim. Etos pracy wyraża zatem zasadnicze posłannictwo chrześcijan w świecie.

\section{Elementy treści kultury w pracy}

Analizując kulturowy wymiar pracy, należy przedstawić zagadnienie elementów kulturowych, generowanych poprzez działalność ludzką. Na podstawie danych socjologicznych można wyróżnić cztery czynniki funkcjonujące $w$ ramach kultury wyznaczające jej treści i znajdujące równocześnie odniesienie w pracy człowieka. Są to wartości, zasady, wzory oraz sankcje ${ }^{25}$.

Pierwszą grupę tychże elementów stanowią wartości ${ }^{26}$. Praca jest wartością samą w sobie. Ów aspekt, przedstawiony powyżej, wyma-

${ }^{24}$ Por. LE 27; T. Borutka, Wielowymiarowość ludzkiej pracy..., dz. cyt., s. 71-72.

25 Zob. B. Szacka, Wprowadzenie do socjologii, Oficyna Naukowa, Warszawa 2008, s. 81-85.

26 Wartość oznacza coś cennego i stanowi walor danej rzeczy. Odnoszona do osoby, potwierdza jej niepowtarzalność i jedyność. Zob. Wartość, w: Słownik języka polskiego, red. W. Doroszewski, PWN, Warszawa 1967, t. 9, s. 855. W znaczeniu filozoficznym wartość oznacza sposób istnienia dobra. Jest więc tożsama z dobrocią, na którą ukierunkowuje się poznanie, urzeczywistniane następnie za sprawą aktów woli. Wartościom przyporządkowane są rzeczy, które mogą stać się przedmiotem pragnień, a niekiedy - w ramach konsekwencji tychże pragnień - także posiadania. Zob. J. B. Lotz, Wert, w: Lexikon fuer Theologie und Kirche, hrsg. V. J. Hoefer, K. Rahner, Freiburg i. Breisgau 1965, kol. 1058-1059. 
ga pewnego dookreślenia. Mianowicie, wartość pracy wynika z faktu, iż praca jest wykonywana przez osobę i stanowi sposób istnienia człowieka. $\mathrm{Z}$ tego względu praca oraz jej owoce muszą być obiektami społecznego szacunku. Pietyzm wobec różnorodnych wytworów pracy stanowi najlepszy środek wychowawczy, skutecznie skłaniający obywateli do zaangażowania w produkcję dóbr. Druga z wymienionych wartości, pracowitość, jest określana przez stopień zamiłowania względem wykonywania danego zawodu lub produkcji dóbr. Miłość do pracy nie może być umniejszana za sprawą towarzyszącego jej trudu i znoju. Skuteczne oddziaływanie miłości w omawianym obszarze jest możliwe przy uwzględnieniu ofiarności i związanej $\mathrm{z}$ nią bezinteresowności. $\mathrm{Z}$ tejże perspektywy wykonywanie pracy nie będzie nosiło znamion cierpiętnictwa, ale stanie się formą kreatywnego zaangażowania, w ramach którego element znoju zostanie udoskonalony - czy nawet przezwyciężony - przez piękno owoców pracy. Do tak określonej pracowitości nawiązują dwie inne, w pewnym stopniu z nią tożsame wartości, a mianowicie wytrwałość ć $^{77}$ i cierpliwość ${ }^{28}$.

Kolejną istotną w kontekście pracy wartością jest odpowiedzialność, wynikająca z odpowiedniości pomiędzy obiektywnymi i subiektywnymi celami działalności człowieka. Innymi słowy, praca wykonywana przez jednostkę nie tylko powinna być wkomponowana w przyjęty kanon norm, ale musi także stanowić formę osobistej partycypacji człowieka w szerszej społeczności, istniejącej w celu przymnażania dobra wspólnego. Partycypacja w dobru wspólnotowym wyraża jednocześnie troskę o godne warunki bytowania ogółu społeczeństwa wedle wskazań redystrybucji. Podział części dóbr wypracowanych przez jednostkę dokonuje się głównie poprzez różnego rodzaju instytucje życia publicznego. Nie można w tym kontekście pomijać znaczenia indywidualnych aktów pomocy, mających najczęściej formę doraźnych reakcji na stan biedy lub niesprawiedliwości społecznej. Realizacja odpowiedzialności poprzez pracę sprzyja ostatecznie kształtowaniu więzi społecznej, dla której wyznacznik stanowi dobro osobowe,

\footnotetext{
27 Wytrwałość wyraża upór i konsekwencję w dążeniu do celu. W aspekcie pracy owa cecha oznacza realizację powołania zawodowego pomimo trudu związanego z działalnością wytwórczą człowieka. Zob. Wytrwałość, w: Słownik języka polskiego, red. W. Doroszewski, PWN, Warszawa 1967, t. 10, s. 301.

${ }^{28}$ Cierpliwość nawiązuje w swojej treści do zachowania spokoju, szczególnie w sytuacjach doświadczania jakichkolwiek przeciwności. Konieczność owej wewnętrznej równowagi jest postulowana również przy długotrwałym wysiłku. Zob. Cierpliwość, w: Słownik języka polskiego, red. W. Doroszewski, PWN, Warszawa 1967, t. 1, s. 998.
} 
a ściślej pragnienie zachowania tego dobra w kontekście uwarunkowań społecznych ${ }^{29}$.

Kolejnym elementem kultury generowanym przez pracę są zasady, określane mianem „nakazów rozumu praktycznego tworzenia wartości wspólnych, jako środków do realizacji zarówno celów osobowych, jak i wspólnotowych (Cz. Strzeszewski)"30. W kulturowym aspekcie pracy istotne są dwie zasady, a mianowicie sprawiedliwość oraz solidarność. Zasada sprawiedliwości w klasycznej koncepcji wyraża się w „trwałej i niezmiennej woli oddawania każdemu tego, do czego ma on prawo” (,iustitia est constans et perpetua voluntas ius suum cuique tribuendi" - koncepcja autorstwa rzymskiego prawnika Ulpiana). W przytoczonym określeniu sprawiedliwości pojawia się element należności, której wyznacznikiem jest stosowna miara $^{31}$. W perspektywie tradycji, powstałej na fundamencie starożytnego określania sprawiedliwości, oraz przy uwzględnieniu nauki chrześcijańskiej można wyróżnić dwa kryteria decydujące o określaniu czynów ludzkich i reakcji wspólnot mianem sprawiedliwych. Pierwsze z tych kryteriów stanowi człowiek. Zachowanie jego godności, integralności, a przede wszystkim wyjątkowości rozstrzyga o właściwym uporządkowaniu świata. Drugim zaś kryterium są prawa, które pośrednio lub bezpośrednio pochodzą od Boga. Własnością praw jest ich komunikowalność, a więc funkcjonowanie w przestrzeni międzyosobowej. Warto zaakcentować, iż sprawiedliwość w swojej istocie stanowi pojęcie relacyjne. Realizacja kryteriów sprawiedliwości sprzyja kształtowaniu środowiska przychylnego człowiekowi, a tym samym rozwojowi stosownej kultury. Zasada sprawiedliwości w takiej właśnie perspektywie znajduje zastosowanie w świecie pracy, co odpowiada podmiotowości człowieka pracującego. Osoba w ramach konstrukcji prawnych stanowi fundament, na którym kształtowane są prawa ludzi pracy chroniące człowieka przed tendencjami redukującymi osobę ludzką do poziomu materii, rzeczy i przedmiotu ${ }^{32}$.

Poczucie sprawiedliwości utwierdzane w jednostce jest stymulowane szczególnie za sprawą przestrzegania postulatu sprawiedliwego wynagrodzenia jako jednego z kluczowych praw pracownika. Konstytucja Gau-

29 Por. J. Gocko, Praca, dz. cyt., s. 951-952.

30 Cyt. za: J. Kupny, Podstawowe zasady życia społecznego, dz. cyt., s. 77.

31 Por. za: B. Szlachta, Sprawiedliwość, w: Słownik społeczny, red. B. Szlachta, Wydawnictwo WAM, Kraków 2004, s. 1343.

32 Por. KNSK 271. 
dium et spes w następujący sposób określa sprawiedliwą płacę: „Praca [...] powinna być tak wynagradzana, by człowiek posiadał możliwości godnego kształtowania egzystencji materialnej, społecznej, kulturalnej i duchowej zarówno siebie samego, jak i swoich bliskich, z uwzględnieniem funkcji oraz wydajności każdego, sytuacji przedsiębiorstwa, a także dobra wspólnego"33. Relacja adekwatności pomiędzy trudem robotnika a płacą nie stanowi jedynego wyznacznika wysokości wynagrodzenia. Istnieje potrzeba uwzględnienia szerszej perspektywy, a więc sytuacji panującej w kraju, możliwości przedsiębiorstwa itd. Usytuowanie społeczne osoby pracującej staje się z kolei filarem postulatu płacy rodzinnej, którą Karta Praw Rodziny określa następująco: „Wynagrodzenie za pracę winno być wystarczające do założenia i godnego utrzymania rodziny, czy to dzięki odpowiedniej płacy, określonej jako «płaca rodzinna», czy też dzięki innym środkom społecznym, jak zasiłki rodzinne bądź wynagrodzenie pracy domowej jednego z rodziców; powinno być ono takie, aby matka nie była zmuszona do pracy poza domem ze szkodą dla życia rodziny, a zwłaszcza wychowywania dzieci" ${ }^{34}$. Wysokość płacy musi zatem być narzędziem zapewnienia wolności w realizacji powołania rodzicielskiego, a więc przede wszystkim w wypełnianiu funkcji prokreacyjnej i socjalizacyjno-wychowawczej. Wywiązywanie się z zadań właściwych rodzinie poprzez odpowiedni dopływ środków uzyskiwanych z pracy zarobkowej rzutuje na skalę udziału ogółu społeczności w dobru wspólnym, obejmującym w równym stopniu dobra natury materialnej i duchowej. Partycypacja w dobru wspólnoty siłą rzeczy wiąże się ze sprawiedliwą redystrybucją dóbr. Kształtowane w tenże sposób poczucie sprawiedliwości najskuteczniej oddziałuje na zmysł prawości obywateli ${ }^{35}$.

Drugą zasadą, będącą elementem pracy w jej wymiarze kulturowym, jest solidarność. Jej określenie znajduje się w encyklice Sollicitudo rei socialis: „[... ] jest to [tzn. solidarność - J.S.] mocna i trwała wola angażowania się na rzecz dobra wspólnego, czyli dobra wszystkich i każdego, wszyscy bowiem jesteśmy naprawdę odpowiedzialni za wszystkich"36. W nauczaniu społecznym Kościoła zasada solidarności dotyczy pierwszoplanowej troski o osobę, zdolną na mocy swojej natury do kształtowania więzi społecznej pochodzącej z przykazania miłości Boga

\footnotetext{
${ }^{33}$ KDK 67.

${ }^{34}$ Karta Praw Rodziny przedłożona przez Stolicę Apostolską wszystkim ludziom, instytucjom i władzom zainteresowanym misją rodziny w świecie współczesnym, Warszawa 1983, art. 10.

35 Por. LE 19; KNSK 302-303; T. Borutka, Wielowymiarowość ludzkiej pracy..., dz. cyt., s. 65-66.

${ }^{36}$ Jan Paweł II, Encyklika „Sollicitudo rei socialis” (30 grudnia 1987), nr 38 [dalej: SRS].
} 
i bliźniego (por. Mt 22,37-38). Solidarność oznacza zatem braterskie współdziałanie mające na celu promocję osoby. W ramach realizacji postulatów solidarności kluczową rolę odgrywa zdolność wczucia się w sytuację drugiego człowieka. Owa postawa transcendowania siebie w kierunku potrzeb bliźniego jest warunkiem koniecznym skutecznego zapobiegania tendencjom indywidualistycznym w społeczeństwie ${ }^{37}$.

Kryteria solidarności znajdują zastosowanie w ramach związków zawodowych, które stanowią formy zjednoczenia robotników mające na celu ochronę własnego dobra ${ }^{38}$ oraz zwiększenie współudziału robotników w dobru społeczności. Nauka Kościoła w zakresie związków zawodowych zawiera przestrogę przed polityzacją lub partykularyzacją ich działalności. Kluczowy winien być zawsze interes robotnika, a także jego najbliższych, gdyż właśnie dla nich miejsce pracy jest przestrzenią humanizacji. Współpraca robotników kształtuje ducha współodpowiedzialności za cały rodzaj ludzki ${ }^{39}$.

Współcześnie solidarne zjednoczenie jest rozwijane także poprzez pewne formy własności, obejmujące akcjonariat, zależności mieszane dóbr publicznych i prywatnych oraz własność spółdzielczą. Celem owego poczucia solidarności jest gromadzenie dóbr przy ciągłym odniesieniu do relacji międzyludzkich. Własność staje się w tymże układzie stymulatorem więzi społecznej ${ }^{40}$.

Kolejny element kultury związany z pracą stanowią wzorce postępowania. Odwołując się do świata pracy, należy wyróżnić dwa typy owych idealnych układów odniesienia. Pierwszy typ obrazują ideologie proponujące wizję rzeczywistości gwarantującą sukces gospodarczy i społeczny. W encyklice Laborem exercens jest mowa o dwóch tego typu ideologiach, a mianowicie o liberalizmie i marksizmie. Ideologia liberalizmu hołduje wolności negatywnej, w imię której pragnienie indywidualnego kumulowania własności, czyli generowania zysku, stanowi jedyny wyznacznik gospodarowania. Natomiast ideologia marksistowska uznaje za jedyną dopuszczalną formę organizacji taki model gospodarki, w ramach którego wyłącznie własność wspólna jest w stanie zapewnić sprawiedliwość społeczną, rozumianą jako kres wyzysku robotników przez przedsiębiorców. Obie ideologie, mimo

\footnotetext{
37 Por. T. Borutka, Propedeutyka katolickiej nauki społecznej..., dz. cyt., s. 63-64.

38 Formą ochrony przed naruszaniem praw ludzi pracy jest strajk, traktowany zawsze jako ostatecznie rozwiązanie w obronie sprawiedliwości społecznej. Zob. LE 20.

39 Por. KNSK 305-309; J. Szulist, Perspektywy ludzkiego rozwoju..., dz. cyt., s. 74-75.

40 Zob. Cz. Strzeszewski, Własność. Zagadnienie społeczno-moralne, Wydawnictwo ODISS, Warszawa 1981, s. 241-242, 246-252.
} 
iż różnią się diametralnie w kwestii przyjętej formy własności, posiadają jeden punkt wspólny; czynią bowiem z człowieka element składowy materialistycznie pojmowanego systemu gospodarowania ${ }^{41}$. „Błąd antropologiczny" leży zatem u podstaw nieludzkich, a więc również antykulturowych, systemów gospodarczych. $Z$ tego względu w gospodarce funkcjonującej we właściwy sposób na pierwszym planie powinien znajdować się człowiek. Osobie ludzkiej musi być podporządkowany kapitał, a więc środki materialne służące realizacji powołania zawodowego. Przesłanka pochodząca z nauczania społecznego Kościoła w powyższym zakresie jest dość jednoznaczna i polega na takim reformowaniu istniejących systemów, by w centrum produkowania i zarządzania dobrami materialnymi znajdowała się właśnie osoba ludzka. Wzór gospodarowania skoncentrowany wokół dobra osoby jest następstwem przyjęcia założenia o prymacie pracy przed kapitałem ${ }^{42}$.

Drugi typ omawianego ideału stanowi zachowanie duchowości pracy. Św. Jan Paweł II podkreśla, iż praca to nie tylko formy aktywności fizycznej, ale także w równej mierze udział ducha, za sprawą którego człowiek ma możliwość uczestniczenia w dziele zbawczym. Duch bowiem udoskonala ciało; jest również adresatem Bożych darów, dzięki którym następuje dalszy proces stworzenia i staje się możliwe przepełnianie świata wartościami ewangelicznymi. Wzór takiego postępowania stanowi Chrystus jako Syn Cieśli (por. Mt 13,55), jednoczący się z ludźmi podejmującymi codzienne wysiłki (por. Mt 11,28). Nieskończona miłość Boża obejmuje wszystkich bez wyjątku, a jej potęga objawiła się na Krzyżu (por. J 19,25-37). Z tego względu człowiek, ponosząc wysiłek związany z pracą, odnajduje w Chrystusie źródło i wzór do realizacji w procesie uświęcania ${ }^{43}$.

Postulat doskonałej jedności pomiędzy fizycznym i duchowym charakterem pracy znalazł swoją najpełniejszą kontynuację w średniowiecznej sentencji „ora et labora” zawartej w regule św. Benedykta. W myśl tejże reguły ideałem życia chrześcijanina jest łączenie wysiłku z kontemplacją. Oba wskazane działania tworzą komplementarną całość sprzyjającą oddawaniu chwały Bogu. Połączenie elementu wysiłku fizycznego i kontemplacji gwarantuje również skuteczność aktywności, owocującą wspaniałymi pomnikami kultury ${ }^{44}$.

\footnotetext{
41 Por. LE 11,13.

42 Por. KNSK 276-280.

${ }^{43}$ Zob. LE 24-27.

${ }_{44}$ Zob. J. Majka, Rozważania o etyce pracy, dz. cyt., s. 14-15.
} 
Ostatni element kultury obecny w wymiarze pracy dotyczy sankcji jako konsekwencji ludzkich czynów. Wywiązywanie się z obowiązków zawodowych i wewnętrzna satysfakcja z pracy skutkują różnymi formami gratyfikacji; są to sankcje pozytywne. Wydajni pracownicy otrzymują dodatkowe premie sprzyjające wzrostowi poziomu dobrobytu, a specjaliści mają przy tym możliwość podnoszenia własnych kwalifikacji. Innymi słowy, gratyfikacja za pracę umożliwia realizację szeroko pojmowanego prawa do rozwoju ${ }^{45}$. Istnieją jednak również sankcje negatywne, stosowane w sytuacjach, kiedy człowiek działa na szkodę przedsiębiorstwa lub nie realizuje właściwego sobie powołania. Owe niekorzystne konsekwencje oznaczają pogłębianie ubóstwa, wyłączenie społeczne i odpowiedzialność karną. Bezpośrednim i znamiennym skutkiem sankcji negatywnych w świecie pracy jest bezrobocie ${ }^{46}$.

\section{Zakończenie}

Kultura wyraża fundamentalny charakter pracy ludzkiej. Wspólny obszar kultury i aktywności zawodowej wyznacza człowiek posiadający nienaruszalną godność i niezbywalne prawa. Podważenie wartości człowieka skutkuje destrukcją porządku stworzenia. Relacja z Bogiem gwarantuje rozwój świata na drodze humanizacji, a więc czynienia świata w większym stopniu odpowiadającym wymogom ludzkiej natury, czyli jeszcze bardziej kulturalnym.

Element godności osobowej, a także praw człowieka, znajduje zastosowanie w świecie pracy. W owym aspekcie jest jednak mowa o godności i podmiotowym charakterze pracy zajmującej nadrzędną pozycję w stosunku do rzeczy materialnych, technologii, a także organizacji miejsca produkcji. Konsekwencją zachowania godnych warunków pracy jest respektowanie praw pracowniczych, służących ochronie człowieka jako uczestnika procesu produkowania i zarządzania dobrami.

Aktywności zawodowej nie można jednak ograniczyć tylko i wyłącznie do sfery produkcyjności. Istota ludzkiego zaangażowania obejmuje wartości, zasady, wzorce i sankcje. Wymienione powyżej treści są elementami składowymi kultury w jej istocie. Poprzez pracę owe elementy nabierają realnego charakteru, optymalizując tym samym relacje międzyludzkie.

45 Por. Paweł VI, Encyklika o popieraniu rozwoju ludów (Populorum progressio) (26 marca 1967), nr 14-15; KNSK 155.

46 Zob. LE 27; zob. również: M. Duda, Bezrobocie przyczyną destrukcji życia rodzinnego, w: Praca kluczem polityki społecznej, dz. cyt., s. 223-224. 
$\$$ 


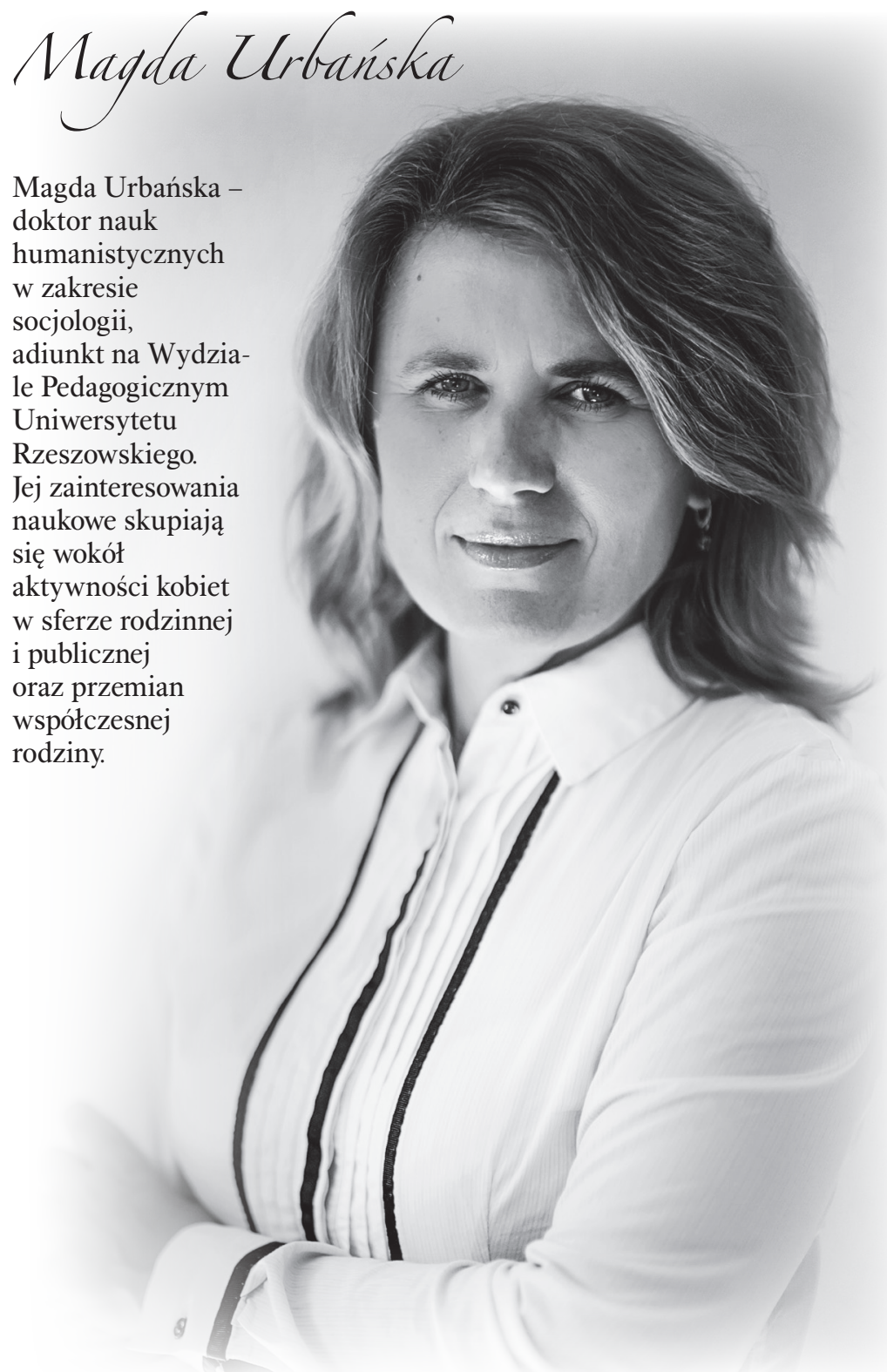




\section{Społeczna wartość pracy w kontekście pracy zawodowej kobiet i mężczyzn}

Wstęp

Praca jest jedną z najważniejszych dziedzin życia człowieka. Wpływa na standard codziennego funkcjonowania, a osiagane z jej tytułu wynagrodzenie pozwala na zaspokojenie indywidualnych i rodzinnych potrzeb. Praca umożliwia realizację zdolności, wpływa na rozwój osobisty oraz zapewnia, w wielu przypadkach, satysfakcję i zadowolenie. Pośród wartości uznawanych przez Polaków za istotne, praca zawodowa znajduje się wśród najważniejszych komponentów udanego i szczęśliwego życia, obok pieniędzy, zdrowia i rodziny ${ }^{1}$.

Według A. Giddensa, praca to zajęcie wymagające wysiłku umysłowego i fizycznego, którego celem jest wytworzenie dóbr i świadczenie usług służących zaspokojeniu ludzkich potrzeb, zarówno o charakterze płatnym w zamian za wynagrodzenie (zawód), jak również o charakterze niepłatnym (prace domowe kobiet, prace społeczne w organizacjach charytatywnych) ${ }^{2}$. F. Adamski wskazuje, że praca jest przypisana naturze człowieka, pozostaje jego prawem oraz obowiązkiem. Na treść pojęcia praca składa się świadome działanie mające na celu zaspokojenie potrzeb przez tworzenie dóbr, trud podejmowany przez pracującego oraz ciężar towarzyszący wysiłkowi fizycznemu, względnie umysłowemu, pracującego człowieka. Z pracą zwią-

\footnotetext{
1 Por. CBOS, Co stanowi o udanym życiu? Komunikat z badań, Nr 167/2014, Warszawa 2014, s. 1-2; CBOS, Wartości i normy. Komunikat z badań, BS/111/2013, Warszawa 2013, s. 1-2.

2 Por. A. Giddens, Socjologia, tłum. A. Szulżycka, Wydawnictwo Naukowe PWN, Warszawa 2004 , s. 397.
} 
zany jest rozwój fizyczny, psychiczny, duchowy i moralny pracującego podmiotu $^{3}$. Encyklopedia socjologii zwraca uwagę, że we współczesnych systemach rynkowych praca definiowana jest jako aktywność skutkująca wymiernymi społecznie korzyściami wycenianymi na rynku w postaci dochodu ${ }^{4}$. Cechą konstytutywną pracy ludzkiej jest jej cel, odnoszący się do pozyskiwania środków służących podtrzymaniu egzystencji gatunku ludzkiego i świata, który stworzył i przyswoił, oraz zwiększanie szans przeżycia w danym środowisku przez jego opanowanie i przetworzenie ${ }^{5}$. Definicja słownikowa odnosi pracę do ogółu świadomie wykonywanych czynności i podejmowanych działań, których celem jest wytworzenie określonych dóbr materialnych lub kulturalnych, warunkujących egzystencję i rozwój społeczeństwa, oraz do pracy jako zajęcia będącego źródłem zarobku .

Wyróżnia się trzy nastawienia do pracy:

- postrzeganie pracy jako instytucji narzuconej pod przymusem. Praca traktowana jest w tym wymiarze jako tragiczne fatum (nastawienie punitywne);

- praca ceniona jest dla korzyści, jakie przynosi jednostce i społeczeństwu. W tym ujęciu praca to konieczność życiowa, podstawa egzystencji (nastawienie instrumentalne);

- praca jako cel sam w sobie, źródło człowieczeństwa i podstawa rozwoju osobistego, a także służba wartościom społecznym (nastawienie autoteliczne $)^{7}$.

W wymiarze jednostkowym praca stanowi bardzo ważny element poczucia własnej wartości. Można ją rozpatrywać w kilku aspektach: wynagrodzenia, czyli źródła utrzymania; poziomu aktywności, jako możliwość nabycia i wykorzystania umiejętności i zdolności; urozmaicenia, jako szansa na wyjście z domu i zmianę otoczenia; struktury czasu, czyli rytmu pracy zawodowej, który reguluje dzień, nadając strukturę codziennym zajęciom; poczucia własnej tożsamości, czyli poczucia stabilnej tożsamości społecznej, poczucia własnej wartości, ekonomicznego wkładu w utrzymanie gospodarstwa domowego oraz kontaktów społecznych, czyli uczestnictwa w życiu społecznym

3 Por. F. Adamski, Praca, w: Encyklopedia pedagogiczna XXI wieku, t. 4, red. T. Pilch, Wydawnictwo Akademickie „Żak”, Warszawa 2005 , s. 781.

${ }^{4}$ Por. W. Kozek, Praca, w: Encyklopedia socjologii, t. 3, red. H. Domański, Oficyna Naukowa, Warszawa 2000, s. 175.

5 Por. tamże, s. 174.

6 Por. Praca, w: Słownik współczesnego języka polskiego, Wydawnictwo Wilga, Warszawa 1996, s. 845.

7 Por. W. Kozek, Praca, dz. cyt., s. 176. 
i kontaktów interpersonalnych ${ }^{8}$. Wymienione wyżej doświadczenia są wspólne dla wszystkich osób pracujących, bez różnicy ze względu na wiek, płeć, stopień sprawności czy doświadczenie zawodowe. Tym samym, jak wskazuje A. Giddens, brak pracy może zachwiać wiarę jednostki w jej społeczną wartość9

W Polsce widoczne są dwa podejścia do pracy. Z badań CBOS wyni$\mathrm{ka}$, że praca jest traktowana w wymiarze autotelicznym oraz wymiarze instrumentalnym ${ }^{10}$. W pierwszym $\mathrm{z}$ nich praca jest wartością samą $\mathrm{w}$ sobie, wiążącą się z przekonaniem, że nadaje sens życiu oraz że warto być pracowitym. Praca traktowana jest wtedy jako wartość autoteliczna i wiąże się odczuciem, że dobre wykonywanie obowiązków wcześniej czy później przyniesie nagrodę czy sukces, że pracowitość jest koniecznym warunkiem sukcesów w życiu oraz że pracę należy wykonywać $\mathrm{z}$ sercem, nawet jeśli nie jest specjalnie znacząca, dlatego że jest ona moralnym obowiązkiem człowieka wobec samego siebie $\mathrm{i}$ innych ludzi. Drugim spojrzeniem na pracę jest spojrzenie poprzez wymiar instrumentalny. W tym przypadku ważnym aspektem pracy jest czynnik ekonomiczny związany $\mathrm{z}$ instrumentalnym traktowaniem wykonywanej pracy, czyli przekonaniem, że praca nie musi sprawiać satysfakcji, a najważniejsze jest, aby przynosiła odpowiednie korzyści materialne, a jeśli ich nie przynosi, to nie warto się $\mathrm{w}$ nią angażować. $\mathrm{W}$ tym ujęciu praca jest przede wszystkim sposobem na zdobycie pieniędzy. W badaniu CBOS z 2013 r. pierwszy z wymiarów określony został mianem samorealizacyjnym, na który składają się takie elementy jak: możliwość pełnego wykorzystania posiadanych kwalifikacji, zgodność zatrudnienia z wykształceniem, zainteresowanie pracą oraz poczucie wagi i znaczenia wykonywanych zadań. Wymiar drugi objęto nazwą stabilizacyjny, przypisując mu satysfakcję z zarobków, zadowolenie ze świadczeń socjalnych oraz pewność zatrudnienia ${ }^{11}$.

\section{Rynek pracy a płé́}

W Polsce przekonanie o potrzebie i wartości społecznej pracy zawodowej kobiet zrodziło się na przełomie XIX i XX wieku. Do tego czasu pra-

\footnotetext{
8 Por. A. Giddens, Socjologia, dz. cyt., s. 396.

9 Por. tamże, s. 397.

10 Por. CBOS, Stosunek Polaków do pracy i pracowitości. Komunikat z badań, BS/38/2011, Warszawa 2011, s. 4-5.

11 Por. CBOS, Zadowolenie z pracy i jej oceny. Komunikat z badań, BS/10/2013, Warszawa 2013, s. 4.
} 
ca kobiet odbywała się jedynie w sferze domowej, zaś praca zawodowa, jako praca przynosząca dochód, była domeną mężczyzn. Istniał kulturowy podział według płci na pracę zarobkową, wykonywaną przez mężczyzn oraz pracę na rzecz rodziny, pozostającą w gestii kobiet. Postulaty prawa kobiet do pracy zawodowej pojawiły się w Polsce w XIX wieku. Orędowniczkami prawa do pracy zawodowej stały się najbardziej znane pisarki tamtego czasu: Klementyna z Tańskich Hoffmanowa, Narcyza Żmichowska, Eliza Orzeszkowa i Maria Konopnicka. Spełnienie ich postulatów nastąpiło w 1921 r., kiedy konstytucja marcowa potwierdziła m.in. prawo kobiet do pra$\mathrm{cy}^{12}$. Za prawem nie szła jednak praktyka dnia codziennego dyskryminująca kobiety w wielu dziedzinach życia zawodowego. Dopiero po II wojnie światowej wprowadzono regulacje prawne, które zapewniły kobietom równe mężczyznom szanse zawodowe. Stopniowo coraz więcej kobiet podejmowało pracę zawodową, kierując się nie tylko względami materialnymi, ale również powodami pozaekonomicznymi, związanymi z coraz wyższym poziomem wykształcenia, aspiracjami zawodowymi czy potrzebą kontaktów społecznych.

Współczesny rynek pracy otwarty jest dla kobiet i mężczyzn, jednak zauważalne stają się różnice w sytuacji pracujących kobiet i mężczyzn. Płeć staje się bowiem jednym z czynników utrudniających lub ograniczających szanse na rynku pracy. $Z$ badań wynika, że kobiety są niżej opłacane niż mężczyźni, częściej zatrudniane w niepełnym wymiarze godzin, pracują w zawodach o niskim prestiżu, zajmując głównie niskie pozycje ${ }^{13}$. Źródeł tego zjawiska można upatrywać w stereotypach płci ${ }^{14}$, które wiążą kobietę ze sferą domową i realizacją roli rodzinnej i macierzyńskiej, a nie z pracą w sferze zawodowej, zarezerwowanej dla mężczyzn. Konsekwencją takiej stereotypizacji jest obarczenie mężczyzny odpowiedzialnością za byt materialny rodziny, a kobiety - za obowiązki domowe. Powoduje to przeciążenie pracujących kobiet pracą domową, wykonywaną obok pracy zawodowej. Stereotypy płci w zakresie aktywności zawodowej zakładają, że kobiety nie mają ambicji zawodowych, gdyż zaspokajają potrzebę samorealizacji

\footnotetext{
12 Ustawa z 17 marca 1921 r. Konstytucja Rzeczypospolitej Polskiej (Dz. U. R.P. nr 44, poz. 267; nr 79, poz. 550; nr 101, poz. 935). Art. 96: „Wszyscy obywatele są równi wobec prawa. Urzędy publiczne są w równej mierze dla wszystkich dostępne na warunkach, prawem przepisanych". 13 Por. B. Szacka, Wprowadzenie do socjologii, Oficyna Naukowa, Warszawa 2008, s. 355.

14 Stereotypy związane z płcią (ang. gender stereotypes) są jednostronnym, zniekształconym obrazem kobiety i mężczyzny, stale pojawiającym się w życiu potocznym. Por. Słownik socjologii i nauk społecznych, red. G. Marshall, tłum. A. Kapciak, Wydawnictwo Naukowe PWN, Warszawa 2006, s. 360.
} 
poprzez wykonywanie prac domowych i opiekę nad dziećmi, mężczyźni zaś muszą osiągać sukces zawodowy, ponieważ nie są w stanie realizować ambicji na płaszczyźnie rodzinnej. Stereotypy dotyczą również przebiegu kobiecej i męskiej kariery, pozostając w ścisłym związku ze stereotypami cech psychicznych oraz fizycznych, określanych jako „kobiece” i „męskie”. Cechy „kobiece” związane są z uczuciowością, ciepłem, wrażliwością, opiekuńczością, zdolnością do poświęceń oraz uległością. Cechy „męskie” odnoszą się do pewności siebie, skłonności do ryzyka, niezależności, agresywności, kompetencji i racjonalności. Cechy te predysponują zatem do wyboru określonych zawodów związanych z tymi cechami oraz nieprzydatność w innych, np. kobiet w zawodach kierowniczych i mężczyzn w zawodach opiekuńczych ${ }^{15}$. Wskazane wyżej stereotypy sprzyjają praktykom dyskryminacyjnym, znacznie ograniczając aktywność zawodową kobiet. Innymi barierami utrudniającymi szanse kobiet na rynku pracy są m.in.: niższe wynagrodzenie, feminizacja zawodów kobiecych, mniejsze możliwości awansu zawodowego i rozwoju zawodowego oraz wyższe bezrobocie.

W Polsce kobiety częściej niż mężczyźni nie pracują, pozostając bierne zawodowo. W 2013 r. współczynnik aktywności zawodowej ${ }^{16}$ wśród kobiet wynosił 48,5\%, wśród mężczyzn 64,4\%, nieznacznie wzrastając od $2010 \mathrm{r}$.

Tabela 1. Współczynnik aktywności zawodowej według płci w latach 2010-2013.

\begin{tabular}{|c|c|c|c|c|}
\hline & \multicolumn{2}{|c|}{ Ogółem (\%) } & \multicolumn{2}{c|}{ W wieku produkcyjnym (\%) } \\
\hline Rok & Kobiety & Mężczyźni & Kobiety & Mężczyźni \\
\hline 2010 & 47,5 & 63,9 & 66,8 & 76,2 \\
\hline 2011 & 48,0 & 64,2 & 67,9 & 76,6 \\
\hline 2012 & 48,3 & 64,4 & 68,8 & 77,2 \\
\hline 2013 & 48,5 & 64,4 & 69,7 & 77,6 \\
\hline
\end{tabular}

Źródło: GUS, Kobiety i mężczyźni na rynku pracy, Warszawa 2014, s. 3.

15 Por. D. Zaworska-Nikoniuk, Stereotyp płci społeczno-kulturowej, w: Encyklopedia pedagogiczna XXI wieku, t. 5, red. T. Pilch, Wydawnictwo Akademickie „Żak”, Warszawa 2006, s. 991-998.

16 Współczynnik aktywności zawodowej to udział osób aktywnych zawodowo (pracujący i bezrobotni), liczony ogółem lub w danej grupie w liczbie ludności (ogółem lub w danej grupie). 
Z badań GUS dotyczących sytuacji kobiet i mężczyzn na rynku pracy wynika, że w IV kwartale 2013 r. wśród kobiet w wieku powyżej 15 lat największą grupę stanowiły kobiety bierne zawodowo $(51,5 \%)$. Kobiety pracujące stanowity $43,4 \%$, bezrobotne $5,1 \%$. W przypadku mężczyzn sytuacja wyglądała odmiennie - mężczyźni najczęściej należą do grupy pracujących (58,5\%), bierni zawodowo stanowią 35,6\%, bezrobotni 5,9\%17. Najwięcej kobiet było aktywnych zawodowo w wieku 40-44 lat, kiedy to na 1000 kobiet 841 pracowało lub poszukiwało pracy, w przypadku mężczyzn najbardziej aktywnym przedziałem wiekowym był wiek 35-39 lat (na 1000 mężczyzn 937 pracowało lub poszukiwało pracy) ${ }^{18}$. Aktywność zawodowa kobiet jest niższa niż mężczyzn we wszystkich grupach wieku. Największe różnice występują jednak w okresie, gdy większość kobiet rodzi dzieci (25-34 lata) oraz w wieku 60-64 lat, w których kobiety mają już prawa emerytalne, a mężczyźni jeszcze ich nie nabyli. Kobiety także częściej niż mężczyźni zmniejszają swoją aktywność zawodową po przejściu na emeryturę ${ }^{19}$. Jeśli przyjrzeć się wskaźnikowi zatrudnienia ${ }^{20}$, widać, że jest on niższy dla kobiet niż mężczyzn, mimo iż od 2010 r. stopniowo wzrastał.

Tabela 2.

Wskaźnik zatrudnienia według płci w latach 2010-2013.

\begin{tabular}{|c|c|c|c|c|}
\hline & \multicolumn{2}{|c|}{ Ogółem (\%) } & \multicolumn{2}{c|}{ W wieku produkcyjnym (\%) } \\
\hline Rok & Kobiety & Mężczyźni & Kobiety & Mężczyźni \\
\hline 2010 & 42,8 & 58,2 & 60,0 & 69,4 \\
\hline 2011 & 42,8 & 58,5 & 60,4 & 69,7 \\
\hline 2012 & 43,0 & 58,4 & 60,9 & 69,9 \\
\hline 2013 & 43,4 & 58,5 & 62,2 & 70,4 \\
\hline
\end{tabular}

Źródło: GUS, Kobiety i mężczyźni na rynku pracy, Warszawa 2014, s. 6.

17 Por. GUS, Kobiety i mężczyźni na rynku pracy, Warszawa 2014, s. 4 . Z danych Głównego Urzędu Statystycznego wynika, że w I kwartale 2015 r. 15,8 mln Polaków pracowało zawodowo, 1,5 mln było bezrobotnych. Aktywnych zawodowo było 17331 tys. osób, z czego mężczyzn - 9525 tys., kobiet -7805 tys. Biernych zawodowo pozostawało 5291 tys. mężczyzn i 8341 tys. Kobiet. Por. GUS, Kwartalna informacja o aktywności ekonomicznej ludności w I kwartale 2015 r. Opracowanie sygnalne, Warszawa 2015, s. 2.

18 Por. GUS, Kobiety i mężczyźni..., dz. cyt., s. 4.

19 Por. Diagnoza społeczna 2013. Warunki i jakość życia Polaków, red. J. Czapiński, T. Panek, Rada Monitoringu Społecznego, Warszawa 2013, s. 127.

20 Wskaźnik zatrudnienia to udział pracujących (ogółem lub danej grupy) w liczbie ludności (ogółem lub danej grupy). 
Pracujące kobiety najczęściej posiadają wykształcenie wyższe (40,3\% ogółu pracujących) lub średnie (31,6\%). Mężczyźni najczęściej posiadają wykształcenie średnie $(35,5 \%)$ oraz zasadnicze zawodowe $(32,6 \%)$. Kobiety częściej niż mężczyźni pracują w sektorze prywatnym, a także ze względu na strukturę statusu zatrudnienia - częściej są pracownikami najemnymi oraz pomagającymi członkami rodzin a rzadziej niż mężczyźni pracują na własny rachunek lub jako pracodawcy ${ }^{21}$.

Kobiety zarabiają mniej niż mężczyźni. W 2013 r. różnica ta wynosiła średnio 17\%, w 2010 r. - 15\%, w 2008 r. - 23\%. Wynagrodzenia kobiet są niższe od wynagrodzenia mężczyzn we wszystkich grupach zawodowych, choć skala ta jest nierównomierna. Rozpiętość przeciętnego wynagrodzenia kobiet i mężczyzn waha się, w zależności od grupy zawodowej, od 1,9\% do 33,7\% na niekorzyść kobiet. Nawet w dziedzinach sfeminizowanych, gdzie pracuje większość kobiet (pracownicy biurowi) przeciętne wynagrodzenie kobiet wynosiło w październiku 2012 r. 98,1\% przeciętnego wynagrodzenia mężczyzny. Różnica wynagrodzeń widoczna jest także wśród osób będących przedstawicielami władz publicznych, wyższych urzędów i kierowników, gdzie w październiku $2012 \mathrm{r}$. przeciętne wynagrodzenie brutto mężczyzny wynosiło ponad 9 tys., a kobiety niespełna 7 tys. W większości sekcji gospodarki narodowej kobiety mają niższe wynagrodzenie niż mężczyźni. Największa różnica dotyczy sekcji Działalność finansowa $i$ ubezpieczenia, gdzie przeciętne wynagrodzenie kobiety wynosi 63\% przeciętnego wynagrodzenia mężczyzny. Na podobnym poziomie wynagrodzenia kobiet i mężczyzn kształtują się w sekcjach: Dostawa wody, gospodarka ściekami i odpadami oraz Administrowanie i działalność wspierająca. Wyższe zarobki mają kobiety pracujące w sekcji Budownictwo oraz Transport i gospodarka maszynowa, ale warto zaznaczyć, że kobiety stanowią tam niewielki odsetek pracujących ${ }^{22}$.

Zmniejszaniu szans kobiet na rynku pracy sprzyja segregacja zawodowa ze względu na płeć. Segregacja dotyczy sytuacji, gdy mężczyźni i kobiety skupieni są w różnych zawodach na postawie założeń dotyczących tego, jakie zajęcia są typowo „męskie”, a jakie typowo „kobiece”23. Takie stereotypowe ujęcie wpływa na aspiracje kandydatów, jak i na selekcję przy rekrutacji do zawodu. Kobiety rzadziej starają się wybierać zawody uważane za „męskie”, a mężczyźni zawody uważane za „kobiece”. Sprzyja to z kolei segregacji poziomej, która występuje, gdy mężczyźni i kobiety pracują

\footnotetext{
21 Por. GUS, Kobiety i mężczyźni..., dz. cyt., s. 6-7.

22 Por. tamże, s. 14-15.

${ }^{23}$ Por. A. Giddens, Socjologia, dz. cyt., s. 413.
} 
w odrębnych zawodach ${ }^{24}$. Drugim zjawiskiem jest segregacja pionowa, która powoduje, że kobiety skupione są w zawodach o małym zakresie władzy i szansach na awans, a mężczyźni zajmują stanowiska dające władzę i wpły$w^{25}$. W kontekście pracy istotne jest, że zawody uważane za „kobiece” są mniej prestiżowe niż zawody uważane za „męskie”, wymagają niższego wykształcenia, są mniej płatne i nie dają władzy. Spojrzenie to widoczne jest także $\mathrm{w}$ polskim rankingu profesji cieszących się uznaniem i szacunkiem społecznym, w którym dominują zawody kojarzone z męską aktywnością i przewagą mężczyzn wśród pracowników. Na czele listy znaleźli się: strażak (87\%), profesor uniwersytetu (82\%), robotnik wykwalifikowany, np. murarz, tokarz (81\%), oraz górnik (80\%). Na 30 zawodów wyróżniono tylko dwa zawody kobiece: pielęgniarkę (78\% - miejsce 6) oraz sprzątaczkę (57\% - miejsce 18$)^{26}$.

W Polsce od lat najbardziej sfeminizowaną grupą zawodową są pracownicy biurowi, pracownicy ustug i sprzedawcy oraz specjaliści, w których kobiety stanowią ponad $60 \%$ ogółu pracujących. Najmniej kobiet jest wśród robotników przemysłowych i rzemieślników oraz operatorów i monterów maszyn i urządzeń (mniej niż 14\%) oraz wśród przedstawicieli władz publicznych, wyższych urzędników i kierowników (ok. 35\%). Najbardziej sfeminizowaną dziedziną gospodarki jest Pomoc społeczna (ponad 80\% pracowników to kobiety) oraz Edukacja (niemal 80\%). Kobiety stanowią ponad 60\% pracowników branży związanej z zakwaterowaniem i gastronomią, a także branży finansowej i ubezpieczeniowej oraz usługowej. Najmniej kobiet (mniej niż 10\%) pracuje $\mathrm{w}$ górnictwie i przemyśle wydobywczym oraz budownictwie ${ }^{27} . \mathrm{Z}$ pracą zawodową kobiet w zawodach „męskich” wiąże się także tzw. „status tokena"28. Pojęciem tym opisywane jest zjawisko widoczności kobiet w branżach, w których zazwyczaj pracują mężczyźni. Z uwagi na niewielką liczbę takich kobiet, ich praca zawodowa poddawana jest szczególnej obserwacji. Bezpośrednimi następstwami tokenizmu są m.in.: koncentracja współpracowników na walorach zewnętrznych kobiet, podporządkowanie się kobiet

\footnotetext{
24 Por. tamże.

25 Por. tamże.

26 W komentarzu do zawodu pielęgniarki dodano, że pełnią one służbę pomocniczą i powszechnie wiadomo, że mało zarabiają. W stosunku do rankingu zawodów z 2008 r. zawód sprzątaczki zyskał na prestiżu 10 punktów procentowych. Por. CBOS, Prestiż zawodów. Komunikat z badań, BS/164/2013, Warszawa 2013, s. 3.

27 Por. GUS, Kobiety i mężczyźni..., dz. cyt., s. 8-9.

28 Por. Bank Światowy, Płeć a możliwości ekonomiczne w Polsce: czy kobiety straciły na transformacji. Raport nr 29205, 15 marca 2004, s. 15.
} 
wzorom zachowań mężczyzn lub oczekiwanie od nich w miejscu pracy zachowań zgodnych ze stereotypem cech psychicznych, tj. opiekuńczości, uległości, lojalności ${ }^{29}$.

\section{Bariery w awansie zawodowym}

Płeć różnicuje także możliwość uzyskania awansu, stanowiąc jedną z jego barier ${ }^{30}$. Kobiety częściej niż mężczyźni zajmują niższe pozycje zawodowe, mimo posiadania odpowiednich kwalifikacji zawodowych. Zjawiska te opisywane są za pomocą określeń: „szklany sufit”, „,szklane ściany”, „lepka podłoga" i „szklane ruchome schody" 31 :

- „szklany sufit” (ang. glass ceiling) to bariera, która nie pozwala kobietom na awans na stanowiska związane z najwyższym szczeblem zarządzania. Jest to „widoczność awansu przy równoczesnej jego nieosiągalności” ${ }^{2}$. Zauważalną oznaką „szklanego sufitu” jest sytuacja, gdy na coraz wyższych szczeblach hierarchii jest coraz mniej kobiet. Awans kobiet jest utrudniony nawet wtedy, gdy posiadają takie samo jak mężczyźni wykształcenie i doświadczenie zawodowe. Nazwa "szklany sufit” bierze się stąd, że bariera awansu jest niewidoczna i nie wynika z przyczyn formalnych, ale ze stereotypów lub kultury organizacyjnej firmy, uniemożliwiającej kobietom awans. Barierami składającymi się na „szklany sufit” są: nastawienie i postępowanie dyrektorów mężczyzn, metody poszukiwania i rekrutacji pracowników, metody doboru pracowników i ich ocena, a także polityka i struktura przedsiębiorstwa, stwarzająca problemy dla osób, które mają obowiązki rodzinne ${ }^{33}$;

- „szklane ściany” to bariera, która odnosi się do sytuacji, gdy utrudniony jest awans na stanowiska kierownicze $\mathrm{z}$ funkcji pomocniczych ${ }^{34}$. Dotyczy to zwłaszcza kobiet zatrudnionych na stanowiskach peryferyj-

${ }^{29}$ Por. D. Zaworska-Nikoniuk, Stereotyp płci społeczno-kulturowej, dz. cyt., s. 997.

30 Por. H. Domański, Zadowolony niewolnik? Studium o nierównościach między mężczyznami i kobietami w Polsce, Wydawnictwo Instytutu Filozofii i Socjologii PAN, Warszawa 1992, s. 67.

31 Por. D. Zaworska-Nikoniuk, Stereotyp płci społeczno-kulturowej, dz. cyt., s. 996-997.

32 A. Titkow, Wstęp. Co pomaga dostrzec „szklany sufit”, w: Szklany sufit. Bariery i ograniczenia karier kobiet. Monografia zjawiska, red. A. Titkow, Fundacja Instytut Spraw Publicznych, Warszawa 2003, s. 9.

${ }_{33}$ Por. tamże, s. 10-11.

${ }^{34}$ Por. tamże. 
nych, pomocniczych, administracyjnych czy wspierających, w dziedzinach, w których są niewielkie perspektywy awansu. Brak awansu motywowany jest tym, że menedżerowie nie wywodzą się ze stanowisk uważanych za wspierające, ale $\mathrm{z}$ centralnych, a na swoich stanowiskach kobiety nie mają możliwości nabycia odpowiedniego doświadczenia zawodowego;

- „lepka podłoga” to sytuacja, w której kobiety dominują w zawodach o niskim statusie oraz niskich zarobkach, w ramach których nie ma możliwości awansu ${ }^{35}$. Kobiety są „przyklejone” do swojego zawodu i pozycji, np. urzędniczki, sekretarki, sprzątaczki, krawcowe, kosmetyczki;

- „szklane ruchome schody” - odnosi się do ograniczenia awansu kobiet w branżach kobiecych ${ }^{36}$. W zawodach stereotypowo postrzeganych jako „kobiece” mężczyźni szybciej awansują oraz zarabiają więcej od kobiet pracujących na tych samych stanowiskach.

W kontekście funkcjonowania kobiet i mężczyzn na rynku pracy warto zwrócić uwagę na czas pracy i rodzaj umowy o pracę. Kobiety częściej niż mężczyźni pracują w niepełnym wymiarze godzin, mniej niż 40 godzin tygodniowo. Mężczyźni przeciętnie pracują tygodniowo o ponad 4 godziny dłużej niż kobiety. Powyżej 50 godzin tygodniowo pracuje 21\% mężczyzn i 7\% kobiet. Na współczesnym rynku pracy ważny jest także rodzaj umowy o pracę zapewniający stabilność zatrudnienia. W przypadku pracowników najemnych niemal 73\% posiada umowę o pracę na czas nieokreślony. Częściej są to osoby w wieku 35-64 lat niż młodsze. Jednakże różnice widoczne są ze względu na płeć i wiek. W przypadku młodszych mężczyzn (15-24 lata) częściej niż kobiety w tym wieku mają umowę na czas nieokreślony (różnica 7 pkt. proc.), z kolei kobiety częściej niż mężczyźni posiadają umowę o pracę na czas nieokreślony w wieku 45-64 lat, co można powiązać z czasem zaprzestania podejmowania decyzji prokreacyjnych ${ }^{37}$. W okresie rodzenia dzieci trudniej jest kobietom otrzymać stałą umowę.

Kobiety częściej niż mężczyźni narażone są na bezrobocie, zwłaszcza na bezrobocie długotrwałe. W 2013 r. kobiety stanowiły 51\% ogólnej liczby zarejestrowanych bezrobotnych, a $41,6 \% \mathrm{z}$ nich pozostawało bez pra-

\footnotetext{
35 Por. tamże.

36 Por. tamże, s. 10.

37 Por. GUS, Kobiety i mężczyźni..., dz. cyt., s. 9-10.
} 
cy ponad 1 rok $(34,9 \% \text { zarejestrowanych mężczyzn })^{38}$. Stopa bezrobocia ${ }^{39}$ jest wyższa wśród kobiet niż wśród mężczyzn.

Tabela 3.

Stopa bezrobocia według płci w latach 2010-2013.

\begin{tabular}{|c|c|c|c|c|}
\hline & \multicolumn{2}{|c|}{ Ogółem (\%) } & \multicolumn{2}{c|}{ W wieku produkcyjnym (\%) } \\
\hline Rok & Kobiety & Mężczyźni & Kobiety & Mężczyźni \\
\hline 2010 & 9,9 & 8,9 & 10,1 & 9,0 \\
\hline 2011 & 10,8 & 8,8 & 11,1 & 9,0 \\
\hline 2012 & 11,1 & 9,3 & 11,4 & 9,5 \\
\hline 2013 & 10,5 & 9,1 & 10,8 & 9,3 \\
\hline
\end{tabular}

Źródło: GUS, Kobiety i mężczyźni na rynku pracy, Warszawa 2014, s. 12.

Kobietom trudniej jest znaleźć pracę po dłuższej przerwie lub poszukującym pierwszej pracy. Także wykształcenie nie chroni przed bezrobociem, mimo iż jest ono rzadsze wśród osób z wyższym wykształceniem. W przypadku kobiet, które posiadają wyższe wykształcenie częściej są one bezrobotne niż mężczyźni z wykształceniem wyższym. Podobnie sytuacja wygląda w przypadku niższych poziomów wykształcenia ${ }^{40}$.

\section{Godzenie obowiązków zawodowych i rodzinnych}

Specyficznym problemem kobiet funkcjonujących na rynku pracy jest także godzenie pracy zawodowej i obowiązków rodzinnych. Ze względu na tradycyjny podział ról częściej jest to bowiem postrzegane jako problem kobiet niż mężczyzn. Wśród rozwiązań na rzecz godzenia obowiązków zawodowych i rodzinnych kobiety częściej wybierają elastyczny czas pracy (56,9\%), lepsze możliwości opieki poza domem dla dzieci do lat 7 (37,1\%), możliwość wykonywania pracy w domu $(24,1 \%)$ oraz dłuższy urlop macierzyński (24\%). Mężczyźni wskazują na dwa pierwsze rozwiązania (odpowiednio 55,1\% i 32,9\%) oraz wyższe zasiłki (24,2\%). Autorzy Diagnozy społecznej zwracają uwagę, że kobiety wyżej cenią zapewnienie opieki dzie-

\footnotetext{
38 Por. tamże, s. 10-11.

39 Stopa bezrobocia to udział bezrobotnych (ogółem lub danej grupy) wśród aktywnych zawodowo (ogółem lub danej grupy).
}

${ }^{40}$ Por. tamże, s. 12-13. 
ciom poza domem, gdyż to one częściej odpowiedzialne są za zapewnienie im opieki pomimo pracy zawodowej. Kobiety wyżej cenią sobie także możliwość pracy domu, pracę w niepełnym wymiarze godzin czy więcej dni wolnych. Mężczyźni z kolei za ważniejsze uznają wyższe zasiłki związane z dziećmi, co wynika z przypisanego im obowiązku dostarczenia dochodu na utrzymanie gospodarstwa domowego. Stąd też mniejszy wymiar czasu pracy lub większa liczba dni wolnych są dla mężczyzn mniej ważne, gdyż wiążą się z obniżeniem dochodu. Kobiety preferują także wydłużenie urlopów macierzyńskich, jednak im większa liczba dzieci w rodzinie, tym rozwiązanie to jest mniej atrakcyjne. Jest to związane z trudnością powrotu kobiety na rynek pracy po przerwie związanej z urodzeniem kolejnych dzie$\mathrm{ci}^{41}$. Jednakże, jak wskazują badania CBOS, praca zawodowa kobiet nie jest traktowana jako niekorzystna dla funkcjonowania rodziny. Przeciwnie, 39\% respondentów uważa, że praca zawodowa kobiet przynosi więcej korzyści życiu rodzinnemu niż strat (przeciwnego zdania jest 12\% respondentów) ${ }^{42}$.

W kontekście funkcjonowania kobiet na rynku pracy warto także zwrócić uwagę na niepokojący trend związany z trudnością godzenia ról. Ze względu na opiekę nad dzieckiem, co druga kobieta w wieku 25-44 nie podejmowała aktywności na rynku pracy. Jednocześnie ponad połowa respondentów Diagnozy społecznej uważała, że trudności związane z godzeniem życia zawodowego i rodzinnego są jednym z głównych powodów rezygnacji z posiadania dzieci. Spośród niemal 10\% badanych obu płci, którzy zrezygnowali z pierwszego lub kolejnego dziecka, 15\% mężczyzn i 23\% kobiet uważało, że trudności z godzeniem ról są jednym z trzech głównych powodów tej decyzji ${ }^{43}$. Pracujące kobiety postrzegane są bowiem często jako pracownicy „problemowi”, których macierzyństwo lub potencjalne macierzyństwo może stać się wyłącznie źródłem kłopotów. W przekonaniu pracodawców macierzyństwo stanowi istotną przeszkodę w wykonywaniu obowiązków zawodowych i wiąże się z nieobecnościami w pracy spowodowanymi opieką nad dzieckiem ${ }^{44}$. Tym samym macierzyństwo pogarsza pozycję kobiety na rynku pracy. W przypadku mężczyzny bycie rodzicem nie wpływa na sytuację zawodową. Wiąże się to z kulturowym stereotypem,

41 Por. Diagnoza społeczna 2013, dz. cyt., s. 130-132.

42 Por. CBOS, Kobieta pracująca. Komunikat z badań, BS/28/2013, Warszawa 2013, s. 12.

43 Por. Diagnoza społeczna 2013, dz. cyt., s. 132.

${ }_{44}$ Por. J. Czernecka, Kobieta, matka, pracownik, w: J. Czernecka, K. Dzwonkowska-Godula, P. Woszczyk, Mama w pracy - społeczne uwarunkowania powrotu kobiet na rynek pracy po przerwie związanej z wychowaniem dziecka, HRP, Łódź 2009, s. 22. 
że jeśli mężczyzna posiada dzieci, to ma także żonę, która się nimi zajmie. Powoduje to, że mężczyźni w małym stopniu korzystają ze swoich pracowniczych uprawnień do opieki nad dziećmi, przez co postrzegani są jako pracownicy dyspozycyjni. Trudnej sytuacji kobiet na rynku pracy nie ułatwia także przekonanie, że kobieta pracująca zawodowo cieszy się większym uznaniem niż gospodyni domowa, zajmująca się tylko prowadzeniem domu i opieką nad dziećmi. Częściej przekonane są o tym same kobiety, jednakże przeświadczenie to umacnia się zwłaszcza wśród mężczyzn ${ }^{45}$.

Jak już wspominano we wstępie, w Polsce dominują dwa podejścia do pracy zawodowej, traktowanej w wymiarze autotelicznym i instrumentalnym. Traktowanie pracy jako wartości samej w sobie widoczne staje się zwłaszcza w sytuacji zaprzestawania tej aktywności. Zmniejsza się bowiem odsetek osób, które byłyby skłonne zrezygnować z pracy na rzecz życia rodzinnego, nawet gdyby pozwoliły na to zarobki partnera/partnerki. Oczywiście częściej taką decyzję skłonne byłyby podjąć kobiety niż mężczyźni (52\% wobec 37\%), warto jednak zwrócić uwagę, że od 2006 r. odsetek ten się zmniejsza. Coraz więcej kobiet chciałoby pracować, nawet gdyby zarobki partnera pozwalały na funkcjonowanie rodziny na satysfakcjonującym poziomie ${ }^{46}$. Może to świadczyć o wzroście znaczenia aktywności zawodowej w życiu kobiet.

Podsumowując, warto na koniec zwrócić uwagę, że bariery i utrudnienia $\mathrm{w}$ funkcjonowaniu kobiet na rynku pracy powoduja, że kobiety rzadziej niż mężczyźni deklarują ogólne zadowolenie z wykonywanej pracy, a także wyrażają mniejsze niż mężczyźni zadowolenie z uzyskiwanych dochodów. Kobiety rzadziej także oceniają swoją pracę jako interesującą, pozwalającą wykorzystać posiadane kwalifikacje, dającą poczucie wagi oraz sensu wykonywanych zadań. Kobiety mają również mniejszą niż mężczyźni pewność zatrudnienia. Kobiety rzadziej niż mężczyźni zmieniają pracę, co może łączyć się z gorszą niż mają mężczyźni oceną swoich szans na rynku pracy ${ }^{47}$.

\footnotetext{
45 Por. CBOS, Kobieta pracująca..., dz. cyt., s. 2-4.

${ }^{46}$ Por. tamże, s. 15.

47 Por. tamże, s. 1.
} 


\section{Zakończenie}

Praca jest jedną z najważniejszych dziedzin życia człowieka oraz jedną z naczelnych wartości. Podejmowanie jej jest prawem człowieka, ale również jego obowiązkiem. Praca stanowi podstawę egzystencji w sensie materialnym, ale także jest źródłem pełniejszego i dojrzalszego człowieczeństwa, podstawą rozwoju osobistego oraz samorealizacji. Może być przyczyną zadowolenia człowieka. W sytuacji postępującego bezrobocia posiadanie pracy jest dobrem najwyższego rzędu, gdyż zapobiega ubóstwu i biedzie, które mogą pociągać za sobą marginalizację czy wręcz wykluczenie społeczne.

W wielości podejmowanych czynności i działań związanych z praca, największe znaczenie przypisywane jest płatnej pracy zawodowej, a więc pracy wykonywanej za wynagrodzeniem. Na współczesnym rynku pracy trwa zatem nieustanna rywalizacja. Jednym z jej obszarów jest współzawodnictwo kobiet i mężczyzn, w którym płeć staje się atutem lub barierą utrudniającą funkcjonowanie w realiach zawodowych. Równym szansom nie sprzyjają przede wszystkim stereotypy i uprzedzenia lokujące kobietę głównie w sferze domowej. Otwiera to drogę praktykom dyskryminacyjnym: trudnościom w zdobyciu pracy zawodowej przez kobiety, jej utrzymaniu, a także barierom na drodze awansu zawodowego. Niższe wynagrodzenie, niższe stanowiska, trudności w rozwoju kariery i wyższe bezrobocie to stały składnik kobiecego funkcjonowania na rynku pracy. Do tego dochodzą specyficzne problemy, związane m.in. z opieką nad dziećmi i osobami zależnymi oraz podwójnym obciążeniem pracą zawodową i obowiązkami domowymi, w niewielkim stopniu będące udziałem pracujących mężczyzn. W konsekwencji kompleks wszystkich tych czynników utrudnia równorzędne mężczyznom funkcjonowanie kobiet w obszarze pracy zawodowej. 
$\$$ 


\section{Dominika Dewonkowska}

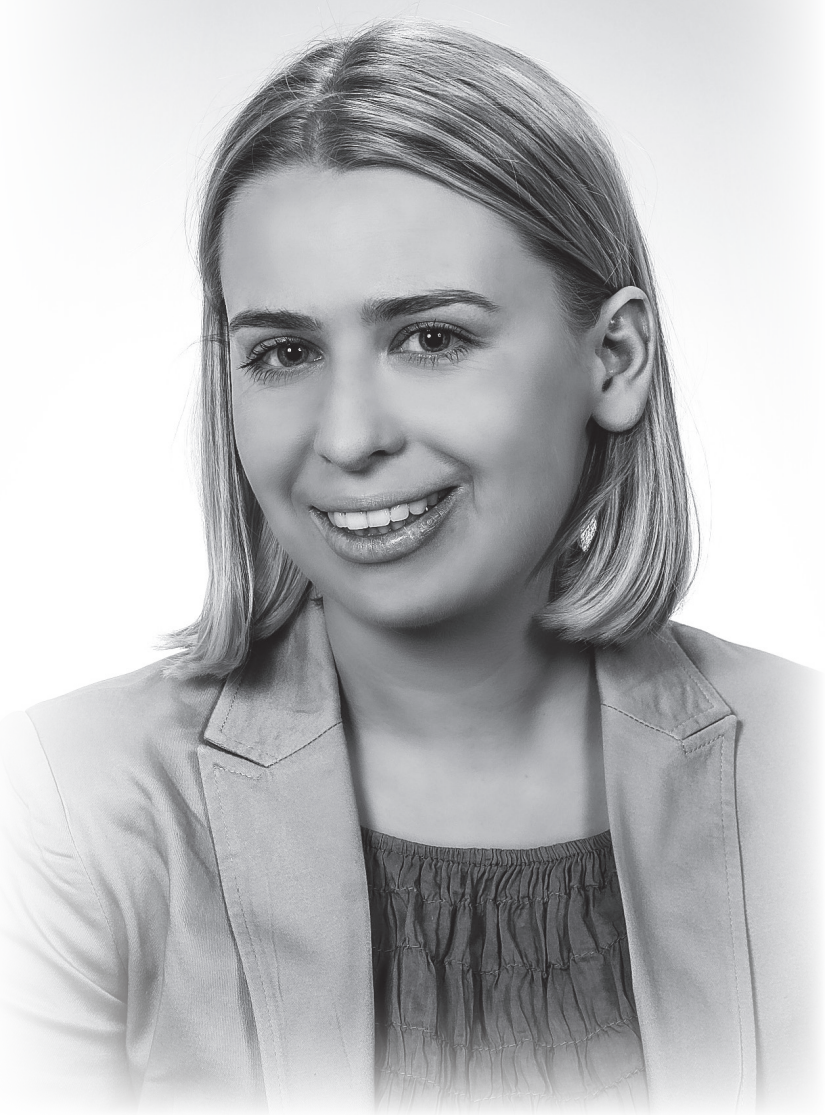

absolwentka filozofii i ochrony środowiska $(2005,2006$, oba kierunki ukończyła z wyróżnieniem) oraz doktor nauk humanistycznych w zakresie filozofii (2011). Pracuje jako adiunkt w Instytucie Ekologii i Bioetyki Uniwersytetu Kardynała Stefana Wyszyńskiego, gdzie prowadzi badania i zajęcia w zakresie ekofilozofii, zrównoważonego rozwoju, etyki środowiskowej, etyki cnót środowiskowych, etyki zwierząt.

Dr Dzwonkowska jest Reprezentantem na Polskę Międzynarodowego Towarzystwa Etyki Środowiskowej. 


\section{Dominika Dzwonkowska \\ Instytut Ekologii i Bioetyki \\ Uniwersytet Kardynała Stefana Wyszyńskiego w Warszawie \\ Cnoty i wady środowiskowe w edukacji ekologicznej}

Wstęp

Niepokojący stan środowiska naturalnego przyczynił się do zwiększenia zainteresowania środowisk akademickich kwestią przeciwdziałania kryzysowi ekologicznemu. Niewątpliwie ochrona środowiska naturalnego jest kwestią na tyle szeroką i interdyscyplinarną, że obejmuje wiele dyscyplin naukowych. Jednak szczególne miejsce w dyskusji zajmuje refleksja etyczna, w ramach której podejmuje się pytanie o moralne zobowiązania człowieka wobec środowiska przyrodniczego. Pytanie to jest zadawane z perspektywy różnych tradycji filozoficznych, w tym także w nawiązaniu do klasycznej etyki cnót, której podstawowym pytaniem jest kwestia cech osobowych człowieka; jakości władz duszy usprawniających w realizacji dobra lub zła moralnego ${ }^{1}$. Cnoty i wady człowieka w etyce cnót środowiskowych stają się narzędziem ochrony bądź destrukcji środowiska naturalnego, są tym, co sprawia, że człowiek bądź działa na rzecz jego ochrony bądź je niszczy.

Zagadnienie to jest ostatnio szeroko dyskutowane w kręgach akademickich, co nawet zaowocowało powołaniem nowej dyscypliny naukowej, czyli etyki cnót środowiskowych (ang. environmental virtue ethics). Jednocześnie cnoty środowiskowe jako sprawności są obszarem, który może, a nawet powinien być włączony do edukacji ekologicznej. Zniszczenie środowiska nie jest problemem aksjologicznie neutralnym, a wiele z codziennych wyborów

1 Por. Z. Pańpuch, Cnoty i wady, <http://www.ptta.pl/pef/pdf/c/cnotyiwady.pdf>, (data dostępu: 12.11.2012). 
człowieka wpływających na stan środowiska dotyczy właśnie kwestii moralnych i sprawności w posługiwaniu się cnotami bądź ulegania wadom. Stąd umieszczenie obszaru aretologii środowiskowej w edukacji ekologicznej jest istotne dla uwrażliwienia na kwestię etycznego wymiaru kryzysu środowiskowego oraz na moralne zobowiązania człowieka wobec środowiska naturalnego.

\section{Znaczenie edukacji ekologicznej w kształtowaniu postaw prośrodowiskowych}

Edukacja jest jednym z najpotężniejszych narzędzi do kształtowania postaw społeczeństwa, od jakiegoś czasu jest również jednym z narzędzi podnoszenia świadomości ekologicznej i krzewienia postaw prośrodowiskowych. Obowiązek prowadzenia tego typu edukacji, zarówno formalnej, jak i nieformalnej, narzuca Ustawa z dnia 27 kwietnia 2001 roku Prawo Ochrony Środowiska (art. 77), która nakazuje, aby zagadnienia związane z ochroną środowiska były uwzględniane w podstawowych programach kształcenia dla wszystkich typów szkół oraz w kursach przygotowujących do zawodu. Ponadto obowiązek prowadzenia edukacji ekologicznej spoczywa na środkach masowego przekazu (prasie, radiu, telewizji), organach administracji, instytucjach naukowych i naukowo-badawczych oraz szkołach wyższych i placówkach, których działalność naukowa wiąże się z ochroną środowiska.

Bardziej szczegółowe wymogi co do charakteru tego typu kształcenia i przekazywanych treści zawarte są w podstawie programowej określanej przez Rozporządzenie Ministra Edukacji Narodowej z dnia 27 sierpnia $2012 \mathrm{r}$. w sprawie podstawy programowej wychowania przedszkolnego oraz kształcenia ogólnego w poszczególnych typach szkół (Dz.U. 2012 nr 0 poz. 977). Rozporządzenie określa, jaką wiedzę posiadają uczniowie kończący poszczególne etapy edukacji ekologicznej i tak na przykład uczeń kończący klasę I szkoły podstawowej w zakresie rozumienia i poszanowania świata roślin i zwierząt:

a) rozpoznaje rośliny i zwierzęta żyjące w takich środowiskach przyrodniczych jak: park, las, pole uprawne, sad i ogród (działka);

b) zna sposoby przystosowania się zwierząt do poszczególnych pór roku: odloty i przyloty ptaków, zapadanie w sen zimowy;

c) wymienia warunki konieczne do rozwoju roślin i zwierząt w gospodarstwie domowym, w szkolnych uprawach i hodowlach itp.; prowadzi proste hodowle i uprawy (w szczególności w kąciku przyrody); 
d) wie, jaki pożytek przynoszą zwierzęta środowisku: niszczenie szkodników przez ptaki, zapylanie kwiatów przez owady, spulchnianie gleby przez dżdżownice;

e) zna zagrożenia dla środowiska przyrodniczego ze strony człowieka: wypalanie łąk i ściernisk, zatruwanie powietrza i wód, pożary lasów, wyrzucanie odpadów i spalanie śmieci itp.; chroni przyrodę: nie śmieci, szanuje rośliny, zachowuje ciszę w parku i w lesie, pomaga zwierzętom przetrwać zimę i upalne lato;

f) zna zagrożenia ze strony zwierząt (niebezpieczne i chore zwierzęta) i roślin (np. trujące owoce, liście, grzyby) i wie, jak zachować się w sytuacji zagrożenia;

g) wie, że należy oszczędzać wodę; wie, jakie znaczenie ma woda w życiu człowieka, roślin i zwierząt;

h) wie, że należy segregować śmieci; rozumie sens stosowania opakowań ekologicznych².

Rozporządzenie określa zakres wiedzy, jaką w zakresie edukacji przyrodniczej i w zakresie rozumienia warunków atmosferycznych powinni posiadać uczniowie poszczególnych klas. Mimo, że edukacja na poziomie podstawowym w pewnym wymiarze uwzględnia kształcenie świadomości ekologicznej, to należy zaznaczyć, że kształcenie w tym zakresie na poziomie akademickim wymaga udoskonalenia ${ }^{3}$. Niemniej edukacja formalna nie wyczerpuje całości edukacji środowiskowej, w ramach której prowadzonych jest szereg działań edukacji nieformalnej, która służy podnoszeniu świadomości ekologicznej. Staje się ona również narzędziem informowania o zmianach w ustawodawstwie, jak chociażby miało to miejsce w przypadku ostatnich zmian w zakresie gospodarki odpadami, gdzie szereg akcji informacyjnych, prowadzonych na różne sposoby, służył powiadomieniu mieszkańców gmin o nowych zasadach odbioru odpadów. Samorządy lokalne odgrywają

2 Por. Rozporządzenie Ministra Edukacji Narodowej z dnia 27 sierpnia 2012 r. w sprawie podstawy programowej wychowania przedszkolnego oraz kształcenia ogólnego w poszczególnych typach szkół (Dz.U. 2012 nr 0 poz. 977), s. 16.

3 Ligia Tuszyńska i Piotr Mazowiecki-Kocyk zwracają uwagę na ten problem, analizując strategie edukacji dla zrównoważonego rozwoju. Zauważają oni, że „istnieje pilna potrzeba opracowania i wprowadzenia podstaw naukowych do kształcenia uniwersyteckiego przedmiotu: Podstawy zrównoważonego rozwoju, ze szczególnym uwzględnieniem kierunków przyrodniczych, społecznych i pedagogicznych". (L. Tuszyńska, P. Mazowiecki-Kocyk, Realizacja strategii edukacji dla zrównoważonego rozwoju wśród społeczności lokalnych w Polsce, w: Odpowiedzialność globalna i edukacja globalna, red. H. Ciążela, W. Tyburski, Wydawnictwo APS, Warszawa 2012, s. 182-188). 
kluczową rolę w prowadzeniu edukacji ekologicznej, „najcenniejszą postacią edukacji ekologicznej jest ta, która wiąże wiedzę teoretyczną z praktyczną, a taki efekt można uzyskać jedynie na poziomie lokalnym, angażując osoby nauczane w ochronę najbliższego im otoczenia. Tak ujęta edukacja środowiskowa jest najlepszym narzędziem wychowywania społeczeństwa w duchu poszanowania środowiska przyrodniczego"4. To właśnie samorządy lokalne, znając uwarunkowania lokalne, są najlepiej przygotowane do przekazania treści ekologicznych w sposób odpowiadający specyfice danego regionu.

Edukacja ma służyć przede wszystkim zapobieganiu negatywnym zachowaniom człowieka. Jak podkreślają Ilona Żeber-Dzikowska i Elżbieta Buchcic, „celem edukacji powinno być kształtowanie postaw proekologicznych, które będą występować przeciw niekontrolowanej eksploatacji zasobów, które będą wykazywać troskę o środowisko przyrodnicze. Prawidłowa równowaga ekologiczna jest możliwa do osiągnięcia jedynie wtedy, gdy ludzie będą przekonani o konieczności rezygnacji z konsumpcyjnego stylu życia (tzw. asceza ekologiczna). W takich warunkach wydaje się nieuniknione wprowadzanie nowych norm etycznych zwanych ekoetyką" ${ }^{5}$. Należy podkreślić, że kwestia ekologiczna nie jest neutralna aksjologicznie, zachowania człowieka w tym obszarze dotykają sfery bonum w sensie etycznym i wymagają uwzględniania w wyborach etycznych dobra, jakim jest środowisko naturalne. Dotychczasowe postrzeganie kwestii środowiska w oderwaniu od namysłu etycznego przyczyniło się do obecnego kryzysu ekologicznego. Jak podkreślają przywołane autorki, „Kwestia ekologiczna dzisiaj wymaga zmiany orientacji, zwrotu w myśleniu, przeobrażeniu mentalności i działań, aby ocalić przyrodę i świat nas otaczający. Rozważania nad kryzysem ekologicznym należy więc prowadzić w aspekcie etycznym, uwzględniając człowieka w jego relacji do środowiska przyrodniczego" ". Zdaje się, że najbardziej adekwatnym narzędziem wprowadzania sfery etycznej do przyszłych zachowań środowiskowych jest edukacja, a edukacja ekologiczna może w szczególny sposób zwracać uwagę na zobowiązania człowieka wobec środowiska naturalnego.

\footnotetext{
${ }^{4}$ D. Dzwonkowska, Edukacja ekologiczna na poziomie lokalnym, „Wybraniec - profesjonalny kwartalnik radnego" 12(2014)3, s. 43.

5 I. Żeber-Dzikowska, E. Buchcic, Etyczny wymiar myślenia i działania ekologicznego w edukacji wczesnoszkolnej, „Studia Ecologiae et Bioethicae” 12(2014)1, s. 76.

6 Tamże, s. 75.
} 


\section{Znaczenie wartości w edukacji}

Kształcenia nie należy postrzegać jedynie jako przekazywania informacji i wiedzy praktycznej, powinno ono wiązać się z kształtowaniem określonych postaw i promowaniem wzorców moralnych. Szczególne miejsce w tak zorientowanej edukacji zajmują wartości i cnoty, „wartości w edukacji służą jako narzędzie do wspierania holistycznego rozwoju osobowego na poziomie intelektualnym, emocjonalnym i duchowym jednostki. Wartości umożliwiają jednostce odczuwać szacunek wobec siebie, innych, lokalnej społeczności, społeczeństwa i całego świata. Umożliwiają dostrzeżenie problemów globalnych i uwzględnianie odpowiedzialności za ich rozwiązanie w indywidualnych wyborach" ${ }^{\prime}$. Edukacja nie powinna być traktowana jako aksjologicznie neutralna, rolą szkoły jest przede wszystkim kształcenie przyszłych obywateli, a nie tylko przygotowywanie do zdawania egzaminów wieńczących kolejne etapy kształcenia. W chwili, gdy szkoła rezygnuje z funkcji wychowawczej i skupi się jedynie na przekazywaniu informacji przestaje pełnić funkcje, dla których została powołana.

Wartości w edukacji są wprowadzane w wielu ośrodkach na całym świecie. Ciekawym przykładem, dobrze opracowanym naukowo, jest Australia. W tym wielokulturowym społeczeństwie wprowadzono edukację opartą na wartościach, która przynosi oczekiwane efekty wychowawcze i jest bardzo dobrym narzędziem pomagającym w kształtowaniu postaw uczniów. Jedną z trudności, z jaką twórcy programów musieli się zmierzyć, był przede wszystkim wybór wartości uznanych za kluczowe, które można wprowadzić w Australii w sposób nie naruszający wrażliwości uczniów pochodzących z różnych kultur, tradycji oraz wyznań ${ }^{8}$. Wśród wartości i norm uwzględnionych w programie znalazły się: troska i współczucie: troska o siebie i o innych; działaj najlepiej, jak umiesz: staraj się osiągnąć coś wartościowego i godnego podziwu. Staraj się najbardziej, jak umiesz, dąż do doskonałości; postępuj uczciwie: chroń wspólne dobro, gdzie wszyscy ludzie są traktowani uczciwie, twórz sprawiedliwe społeczeństwo; wolność: ciesz się prawami i przywilejami australijskiego obywatelstwa bez zakłóceń i kontroli, chroń prawa innych; uczciwość i wiarygodność: bądź uczciwy, szczery i dąż do prawdy; prawość: działaj w zgodzie z zasadami moralnego i etycznego postępowania, zapewniaj zgodność pomiędzy słowami i czy-

7 D. Dzwonkowska, Rola wartości w edukacji globalnej, w: Odpowiedzialność globalna ..., dz. cyt., s. 170.

8 Por. także: tamże, s. 179. 
nami; szacunek: traktuj innych z uznaniem i szacunkiem, respektuj punkt widzenia innej osoby; odpowiedzialność: ponoś odpowiedzialność za swoje działania, rozwiązuj konflikty w konstruktywny, pozbawiony przemocy i pokojowy sposób, bierz udział w życiu społecznym i obywatelskim, troszcz się o społeczeństwo; zrozumienie, tolerancja i integracja: bądź świadom innych i ich kultur, akceptuj różnorodność w społeczeństwie obywatelskim, włączaj siebie i innych ${ }^{9}$.

Kluczowe znaczenie ma odpowiedni dobór wartości, które będą włączone do edukacji. Bez skupienia się na kształtowaniu odpowiednich postaw, edukacja w wartościach może stać się karykaturą samej siebie na wzór systemów kształcenia w państwach totalitarnych, w których kluczowe wartości edukacji są kształtowane wokół postaci totalitarnego przywódcy czy promowania antywartości tak modnych w społeczeństwach konsumpcyjnych. Wartości uwzględnione w programie wdrożonym w Australii spełniają zadanie wspomagania rozwoju emocjonalnego i etycznego uczniów, przyczyniając się do polepszenia stosunków między uczniami oraz między uczniami i nauczycielami w szkole.

Doświadczenia nauczycieli ze szkół objętych programem nauczania w wartościach pokazują pozytywną zmianę, jaka nastąpiła w uczniach $\mathrm{i}$ ich relacjach $\mathrm{z}$ innymi uczniami bądź z nauczycielami. Jeden $\mathrm{z}$ nauczycieli odnotował, że studenci stali się dużo spokojniejsi i wydają się szczęśliwsi, poprawiły się relację między zatrudnionym personelem a dziećmi, ponadto uczniowie są mniej skoncentrowani na sobie niż byli na początku projektu, co przejawia się między innymi większą chęcią pomocy innym i zachowaniami altruistycznymi ${ }^{10}$. Program okazał się także pomocny w rozwiązywaniu problemów z budowaniem relacji społecznych między studentami. W raporcie opisano przypadek studenta, który miał trudności z czytaniem, pisaniem i zapamiętaniem imion innych uczniów z klasy. Znał tylko swoje imię i imię swojego najlepszego przyjaciela, co zostało zinterpretowane jako przejaw braku postrzegania szkoły i klasy jako miejsca nawiązywania relacji interpersonalnych. Niemniej w trakcie realizacji programu zaczęły zachodzić w chłopcu zmiany: po pierwsze on sam zaczął doceniać uczniów ze swojej klasy, ale także oni zaakceptowali go takim, jaki jest, włącznie ze

9 Por. I. Snook, Values Education in Context, w: Values Education and Lifelong Learning, red. D.N. Aspin, J.D. Chapman, Springer, Dordrecht 2007, s. 81.

10 Por. B. Vaughan, Giving Voice to the Impacts of Values Education. The Final Report of the Values in Action Schools Project, GEON Impact Printing Pty Ltd, 2010, s. 24. 
zrozumieniem dla jego trudności w pisaniu ${ }^{11}$. Okazywanie szacunku dla innych uczniów oraz zrozumienie, szczególnie gdy uczniowie mają trudności z nadążeniem za resztą klasy, stoi w sprzeczności z modelami edukacji promującymi niezdrową rywalizację. W tym przypadku ten pierwszy model okazał się bardzo skuteczny w adaptacji ucznia do klasy, podczas gdy w modelu rywalizacyjnym uczeń ten nie miałby szans na pełen rozwój osobowy, a być może byłby potraktowany jako przeszkoda na drodze do szybszego rozwoju umiejętności i wiedzy innych uczniów. Ramy programu pozwalają stworzyć przestrzeń dla rozwijania wartości pomocnych w efektywnym komunikowaniu się, tworzeniu dobrych relacji oraz służących własnemu rozwojowi uczniów, szczególnie rozwijaniu ich wrażliwości na moralność i jej znaczenie w codziennych wyborach.

Szczególne znaczenie w programie mają nauczyciele, od których zaangażowania we wprowadzanie wartości zależy sukces lub porażka programu. W przypadku nauczycieli ważna jest nie tylko wiedza o danej cnocie bądź wartości i dogłębne jej zrozumienie, ale także przejawianie zachowań zgodnych z daną wartością w życiu codziennym. Uczniowie są bardzo uważnymi obserwatorami, jeżeli zauważą chociaż najdrobniejszą niespójność czy sprzeczność słów nauczyciela z jego zachowaniem, wtedy będą mieli wątpliwości co do zasadności praktykowania tej wartości, a nawet możliwości wprowadzenia jej w życie. Nauczyciel, określany przez Johna Dewey’a jako „nagromadzona wiedza rasy ludzkiej”"12, przekazuje tę wiedzę, zrozumienie i umiejętności, które ludzkość odziedziczyła, tym, którzy aktualne mają ograniczone zrozumienie i możliwości ${ }^{13}$. Nauczyciel powinien dzielić się z uczniami swoim człowieczeństwem ${ }^{14}$, szczególnie własną postawą, pokazując, jak należy żyć wartościami, które są przedmiotem nauczania. W programach nauczania uwzględniających wartości ethos nauczyciela poszerzony jest o szczególną troskę o życie nauczanymi wartościami. Zresztą, należy podkreślić, że większość kodeksów etycznych nauczycieli przyjmowanych w różnych placówkach oświatowych podkreśla znaczenie wysokich standardów etycznych i nienagannego prowadzenia się nauczyciela.

\footnotetext{
11 Por. tamże, s. 25

12 Por. International research handbook on values education and students wellbeing, red.

T. Lovat, R. Toomey, N. Clement, Springer Dordrecht, Heidelberg, London, New York 2010, s. xxi.

13 Por. tamże.

14 Por. tamże.
} 
„Wartości były obecne w teorii edukacji od Platona - czy w postaci popierania wglądu w formę dobra czy według Arystotelesa w dowodzeniu znaczenia dobrych nawyków jako wstępu do życia w cnocie, bądź według Dewey’a w promowaniu społecznych norm, które konstytuują społeczeństwo demokratyczne"15. Niemniej, często w edukacji brakowało wyraźnego zarysowania wartości, co z czasem doprowadziło do ich zatracenia i uczynienia edukacji działalnością oderwaną od sfery aksjologicznej. Kryzys moralny skłonił do ponownej refleksji nad zagadnieniem wartości i stał się przyczyną wzmożonego zainteresowania kwestią wartości i cnót w edukacji, a co za tym idzie również pojawienia się programów czy jednorazowych akcji szkolnych skierowanych na promocję wartości w kształceniu młodzieży szkolnej.

\section{Typologia cnót i wad środowiskowych}

Cnoty i wartości mogą stać się narzędziem do kształtowania pożądanych zachowań społecznych. Mimo, że odnoszą się praktycznie do każdego obszaru codziennego życia, często są pomijane w dyskusjach nad tak istotną kwestią jak ochrona środowiska. Często dyskusje wokół problemu degradacji środowiska naturalnego koncentrują się na próbach udowadniania wartości środowiska oraz krytykowania postaw antropocentrycznych przy jednoczesnym braku wskazania postaw człowieka, które mogły by pomóc rozwiązać ten problem. Warto zatem przyjrzeć się dyskusji nad zagadnieniem kardynalnych cnót i wad środowiskowych, w którym przewija się wiele propozycji typologii kardynalnych cnót i wad środowiskowych.

Sam termin cnota jest terminem używanym w etyce od czasów starożytnych, jest to termin, który wprawdzie może wydawać się terminem kaznodziejskim, ale ma w filozofii bardzo długą tradycję, a w omawianym, środowiskowym kontekście, jest używany od niedawna. Zapoczątkowanie współczesnej dyskusji na temat cnót przypisuje się Elizabeth Anscombe, której artykuł z 1958 pt. Modern Moral Philosophy ponownie zwrócił uwagę na zapomniane klasyczne zagadnienie etyki. Nieco później zagadnienie to zagościło również w dyskusjach z zakresu etyki środowiskowej. Najczęściej początek tych dyskusji przypisuje się opublikowaniu przez Thomasa Hilla Jr. artykułu Ideals of human excellence and preserving natural environments

15 Tamże, s. v. 
w 1983 roku $^{16}$. Philip Caffaro twierdzi jednak, że dyskusja nad etyką cnót środowiskowych rozpoczęła się jeszcze wcześniej i podaje kilka dzieł, które jego zdaniem można by uznać za pierwsze w tej debacie. W pierwszej kolejności odwołuje się do jednego z najważniejszych dzieł transcendentalizmu amerykańskiego stanowiącego inspirację dla ekofilozofii - Walden autorstwa Henry'ego Dawida Thoreau, opublikowanego w 1854 roku. Jak podkreśla dalej, źródłem tej dyskusji może być Polityka Arystotelesa (połowa IV w.p.n.e) czy wręcz pojawienie się Tao Te Ching ${ }^{17}$, gdyż każde z tych dzieł zawiera odniesienie do zagadnienia cnót w kontekście, który jest istotny dla ochrony środowiska naturalnego.

Niewątpliwie zagadnienie cnót i wad oraz ich środowiskowego odniesienia pojawia się w wielu dziełach i ma korzenie sięgające daleko dalej niż uważany za początek debaty artykuł Thomasa Jr. Hilla. Etyka cnót środowiskowych jest zagadnieniem ważnym dla kwestii ekologicznej oraz może stanowić skuteczny instrument w przezwyciężeniu kryzysu ekologicznego. Same cnoty i wady środowiskowe są jakością władz duszy usprawniających w realizacji dobra lub zła moralnego w kontekście ochrony środowiska naturalnego. Czy można więc mówić o głównych jakościach władz duszy stojących za ochroną bądź degradacją środowiska naturalnego?

Jedną $\mathrm{z}$ dyskusji podejmowanych $\mathrm{w}$ ramach debaty o cnotach i wadach środowiskowych jest dyskusja nad tzw. kardynalnymi cnotami i/lub wadami środowiskowymi. Sam termin «kardynalne cnoty» prawdopodobnie po raz pierwszy został użyty przez Ambrożego, arcybiskupa Mediolanu. „Słowo cardo oznacza istotę, to, wokół czego rzeczy się obracają, ich kluczowy punkt"18. Tradycyjnie w etyce wyróżnia się cztery cnoty kardynalne: 1. roztropność, 2. sprawiedliwość, 3. męstwo, 4. umiarkowanie (wstrzemięźliwość $)^{19}$. W etyce cnót środowiskowych pojawia się kilka innych typologii

\footnotetext{
16 Th. E Hill, Ideals of Human Excellence and Preserving Natural Environment, "Environmental Ethics" 5(1983)2, s. 211-224.

17 Por. P. Cafaro, Environmental Virtue Ethics Special Issue: Introduction, "Journal of Agricultural and Environmental Ethics" 23(2010)1-2, s. 4; B. Treanor, Environmentalism and public virtue, "Journal of Agricultural and Environmental Ethics" 23(2010)1-2 , s. 9-28.

18 Cardinal Virtues, <http://www.newadvent.org/cathen/03343a.htm>, (data dostępu: 04.04.2014).

19 Również w etyce cnót środowiskowych pojawiają się głosy łączące współczesną debatę z klasyczną etyką cnót, przykładem może być chociażby oryginalna koncepcja etyki cnót środowiskowych według Louke van Wensveen, która klasyczną teorię cnót zestawia ze współczesnymi dyskusjami neuroetyki, etyki analitycznej oraz etyki środowiskowej.
} 
cnót i wad środowiskowych. Zostanie przedstawiona ta z nich, która wyróżnia następujące pary cnót $\mathrm{i}$ ich przeciwieństw: troska - egoizm, umiarkowanie - chciwość, szacunek - arogancja, mądrość - ignorancja, odpowiedzialność - obojętność ${ }^{20}$.

Pierwsza para zawiera w sobie największe wyzwanie współczesnych społeczeństw zachodnich - mianowicie egoizm, który jest fetyszyzacją ja, własnego interesu i swoich własnych upodobań. Egoizm trawi społeczeństwa zachodnie i zaślepia jednostki na dobro innych, tym bardziej nie pozwala dostrzec dobra środowiska naturalnego. Współcześnie jednostka jest wychowywana do nieskrępowanej realizacji własnych potrzeb i przedkładania ja nad drugiego. Egoizm jest fundamentem i źródłem innych, wad to z niego wypływa chciwość, arogancja, ignorancja i obojętność wobec innych czy kwestii środowiskowej. Jest przyczyną zatracenia człowieka w przeżywaniu własnego świata bez dostrzegania bliźniego. Panaceum na egoizm jest poszerzenie ram świata jednostki, a szczególnie ram zakresu jej etyki o uwzględnianie drugiego, o uwzględnianie środowiska poprzez troskę o nie. Troska o środowisko i jego elementy jest lekiem uwalniającym $\mathrm{z}$ nieustannego skoncentrowania na własnym ja, jest dostrzeżeniem konieczności ochrony środowiska, którego niektóre ekosystemy stają się zagrożone w zetknięciu z człowiekiem.

Troska o środowisko może przyjmować różne formy. Jedną z nich jest chociażby umiarkowanie, które jest skutecznym lekarstwem na chorobę chciwości. Umiarkowanie ma kluczowe znaczenie w rozsądnym gospodarowaniu ograniczonymi zasobami środowiskowymi, gdy myśli się o dzisiejszym świecie w kontekście sprawiedliwości globalnej widać dwa różne światy. Jeden to południowa półkula, na której mieszkańcy rozwiniętych państw mają zaspokojone wszystkie podstawowe potrzeby, a wielu z nich marnotrawi cenne zasoby, takie jak chociażby energia, woda i pożywienie. Świat ten różni się od półkuli południowej, na której niektórzy mieszkańcy umierają z głodu i nie mają dostępu do wielu wygód cywilizacyjnych, jak chociażby bieżącej wody, kanalizacji czy elektryczności. To chciwość sprawia, że wielu mieszkańców bogatych społeczeństw nie umie rozsądnie korzystać z dóbr. Już w czasach starożytnych dostrzegano istotne znaczenie

${ }^{20}$ Więcej na temat tej klasyfikacji cnót można znaleźć w artykułach: D. Dzwonkowska, Virtue and vice in environmental discourse, „Studia Ecologiae et Bioethicae” 11(2013)4, s. 61-76 oraz taż, Wady środowiskowe jako etyczne $i$ antropologiczne źródła kryzysu środowiskowego, „Studia Ecologiae et Bioethicae” 12(2014)1, s. 79-91. 
tej wady dla rozwoju moralnego człowieka. Sam Arystoteles określa „chciwość" jako cechę przypisywaną tym, którzy o dobra materialne dbają więcej niż się powinno ${ }^{21}$. Obecnie chciwość przejawiająca się w konsumpcjonizmie i bezrefleksyjnym marnotrawieniu zasobów, stanowi zagrożenie dla środowiska naturalnego. Rozwiązaniem problemu chciwości powinno być umiarkowanie, które pozwoli człowiekowi kierować się w wyborach rozumem i roztropnością, a nie zachciankami. Umiarkowanie pozwala odzyskać kontrolę nad własnym gospodarowaniem zasobami, jakimi się dysponuje, oraz pozwala je wykorzystać w sposób racjonalny służący zaspokojeniu rzeczywistych potrzeb.

Umiarkowanie i rozsądne gospodarowanie zasobami zasługują na szacunek, który jest kolejną kardynalną cnotą środowiskową. Szacunek jest lekarstwem na arogancję człowieka, to właśnie arogancja i pycha były często uważane za jedne z kluczowych wad współczesnego człowieka, a w kontekście środowiska naturalnego często arogancję wiąże się z postawą antropocentryczną. Antropocentryzmowi w skrajnej postaci przypisuje się niedostrzeganie kwestii środowiskowej oraz dbanie tylko i wyłącznie o zaspokajanie potrzeb własnego gatunku, a wartość i znaczenie innych gatunków uzależnia się co najwyżej od ich przydatności dla realizacji celów ludzkich. Tego typu postawa została poddana w ramach etyki środowiskowej szerokiej dyskusji. Jednym ze stanowisk szczególnie przydatnych w przełamaniu arogancji może być szacunek okazywany wszelkim formom życia w wersji, jaką prezentuje chociażby Albert Schweitzer. Jego troska o środowisko naturalne jest przesiąknięta ogromną estymą, jaką darzy wszelkie formy życia. O potrzebie szacunku i jego znaczeniu dla ochrony środowiska może świadczyć fakt, że według analiz językowych literatury z zakresu etyki środowiskowej szacunek jest drugą najczęściej omawianą wartością ${ }^{22}$. Szacunek wobec innych form życia powinien być wyrazem prawdziwego człowieczeństwa, prawdziwie humanistycznej postawy, w której jest miejsce na wszelkie formy życia i odpowiednią postawę wobec nich.

Czwartą kardynalną cnotą, bez której nie można mówić o ochronie środowiska, jest mądrość, która jest odpowiedzią na ignorancję utożsamianą z niewiedzą: niewiedzą o zobowiązaniach moralnych wobec środowiska, jak i niewiedzą o tym, jak właściwie chronić środowisko. Tak ujęta niewiedza sta-

${ }_{21}$ Por. Arystoteles, Etyka Nikomachejska, Tłum. D. Gromska, PWN, Warszawa 2007, 119b.

22 Por. L. van Wensveen, The emergence of Ecological Virtue Language, w: Environmental Virtue ethics, red. R. Sandler, P. Cafaro, Rowman \& littlefield publisher Inc., Oxford 2005. 
nowi bardzo realne zagrożenie dla środowiska naturalnego i wszystkich jego elementów. Stąd działaniami wobec środowiska powinna kierować mądrość, mądrość, której znaczenie w podejmowaniu wyborów moralnych podkreślał już Sokrates. Brak tej mądrości skazuje ludzi na środowiskowy analfabetyzm, przez który stanowią zagrożenie dla siebie samych i otoczenia.

Człowiek mądry kieruje się w swoich wyborach odpowiedzialnością, która jest jedną z najczęściej przywoływanych wartości środowiskowych, a w niniejszym zestawieniu jest przeciwstawiona wadzie obojętności. To właśnie obojętność często jest matką niewiedzy, gdyż to ona powstrzymuje przed szukaniem wiedzy o ochronie środowiska, a nawet dostrzeżeniem kwestii środowiskowej. Obojętność jest konformistycznym odsuwaniem się od kwestii ochrony środowiska, jest nieodpowiadaniem na wezwanie, jakie stawiają przed ludźmi problemy związane z degradacją licznych ekosystemów. Lekarstwem na tę wadę jest odpowiadanie na zagrożenie środowiska. To właśnie termin „odpowiadać” jest źródłosłowem terminu odpowiedzialność w wielu językach europejskich. Owa odpowiedzialność nie powinna być tylko odpowiedzialnością negatywną występującą post factum, odpowiedzialnością za coś, co się wydarzyło. Powinna przyjmować formę odpowiedzialności pozytywnej, stałej odpowiedzialności za środowisko. Odpowiedzialność taką porównywał Hans Jonas $^{23}$ do odpowiedzialności, jaką rodzice czują za dziecko.

Te pięć par cnót i wad środowiskowych niewątpliwie nie wyczerpuje bogatej dyskusji nad katalogiem cnót i wad związanych z ochroną bądź niszczeniem środowiska naturalnego. Można by zaryzykować stwierdzenie, że niemalże każda cnota ma swój zielony odcień, a kluczowe znaczenie w rozpoznaniu zobowiązania moralnego ma rozróżnianie dobra od zła. Niniejszy katalog cnót i wad środowiskowych jest jedynie skromnym przyczynkiem do dyskusji i próbą zwrócenia uwagi na powiązanie działań moralnych i zagadnień aretologicznych z kwestią ekologiczną. Tak ujęte cnoty i wady mogą stać się przedmiotem edukacji środowiskowej, która ma na celu ukazanie znaczenia ludzkich wyborów moralnych w kontekście ochrony środowiska. Należy podkreślić, że ochrona środowiska to nie tylko i wyłącznie stosowanie określonych technologii służących naprawieniu tego, co człowiek zniszczył, to nie tylko zewnętrzne przepisy i normy dyktujące określone postawy wobec otoczenia przyrodniczego. Ochrona środowiska to również,

${ }^{23} \mathrm{H}$. Jonas, Zasada odpowiedzialności. Etyka dla cywilizacji technologicznej, tłum. M. Klimowicz, Platan, Kraków 1996. 
a może nawet przede wszystkim, szereg indywidualnych wyborów i działań, które są kierowane dyspozycją do czynienia dobra i zła. Owa dyspozycja jest właśnie cnotą lub wadą środowiskową, która pomaga chronić środowisko lub wręcz przeciwnie, przyczynia się do jego zniszczenia. Dychotomia cnót i wad środowiskowych pozwala lepiej ukazać, jak należy chronić środowisko, jak przejawia się cnota i jak przejawia się jej brak. Ujmując cnotę na wzór arystotelesowski, należałoby ją rozumieć jako złoty środek między dwoma skrajnościami, jako środek między tym, czego całkowicie brakuje albo co jest w nadmiarze. W niniejszej typologii jedna ze skrajności pojawiać się może jako wada środowiskowa, jako rażący brak owej cnoty, która jest istotna w ochronie środowiska.

\section{Zakończenie}

Programy wychowania w wartościach są najbardziej skuteczne, gdy są wprowadzane w różne obszary aktywności uczniów, tj. zarówno do zajęć lekcyjnych, jak i aktywności pozalekcyjnej. Dana wartość może być ukazana w czytance szkolnej, zadaniu matematycznym, ale także jako część gazetki szkolnej, temat przedstawienia czy rozmowy z nauczycielem w trakcie lekcji wychowawczej. Również i edukacja ekologiczna nie powinna być aksjologicznie neutralna powinna kształtować moralną świadomość uczniów i pomagać im dokonywać świadomych wyborów moralnych. Edukacja ekologiczna powinna ukazywać ochronę środowiska jako wybór, który nie jest aksjologicznie obojętny. Można odnotować niebagatelną rolę, jaką odegrała ta forma kształcenia w formowaniu świadomości ekologicznej Polaków. W ciągu kilku lat miliony osób dostrzegły problemy środowiskowe, których wcześniej sobie nie uświadamiały oraz dzięki edukacji formalnej i nieformalnej nauczyły się jak zapobiegać tego typu problemom bądź jak je rozwiązywać.

Niemniej, przed edukacją ekologiczną stoi również zadanie uwrażliwiania sumienia ekologicznego oraz kształtowania świadomości moralnych zobowiązań człowieka wobec kwestii środowiskowej. Pomocna może się tu okazać edukacja promująca cnoty środowiskowe i pokazująca ich znaczenie w ochronie środowiska na wzór Thomasa Hilla Jr. ${ }^{24}$, który zdaniem niektórych, kieruje dyskusję nad etyką środowiskową ku wnętrzu człowieka, ku jego sprawnościom. Tak samo edukacja ekologiczna odwołująca się do

\footnotetext{
${ }^{24}$ Por. T. E. Hill, Ideals of Human Excellence ..., dz. cyt.
} 
zagadnienia cnót środowiskowych pozwala dostrzegać moralne zobowiązania człowieka wobec środowiska, ujmować ochronę i niszczenie środowiska w kategoriach dobra i zła moralnego, ale przede wszystkim wskazuje, iż cechy osobowościowe człowieka mają swój udział w odpowiedzialnej ochronie środowiska.

Szczególną rolę we wspieraniu budowania świadomości ekologicznej oraz uświadamianiu moralnego wymiaru relacji człowiek - środowisko może pełnić autorytet Kościoła katolickiego. To Kościół, w osobie Papieża Franciszka, zabrał głos w tej palącej sprawie w encyklice Laudato Si, która zwraca uwagę na szereg istotnych czynników związanych z moralnym wymiarem kryzysu środowiskowego. W sposób głęboko refleksyjny i mądrościowy rozważany jest tu również wymiar własnego wkładu w przezwyciężenie kryzysu poprzez pielęgnowane cnót. Ojciec Święty zwraca bowiem uwagę, że „prawa i przepisy nie wystarczą na dłuższą metę, aby ograniczyć złe zachowanie, nawet jeśli istnieje skuteczna kontrola. Jeśli norma prawa ma wywołać znaczące i trwałe skutki, trzeba, aby większość członków społeczeństwa ją zaakceptowała, wychodząc $\mathrm{z}$ właściwych motywacji, i podjęła osobistą przemianę. Dar z siebie w działalności ekologicznej staje się możliwy jedynie poprzez doskonalenie się w cnotach"25.

25 Franciszek, Encyklika „Laudato Si” (24 maja 2015), nr 211. 
$\$$ 

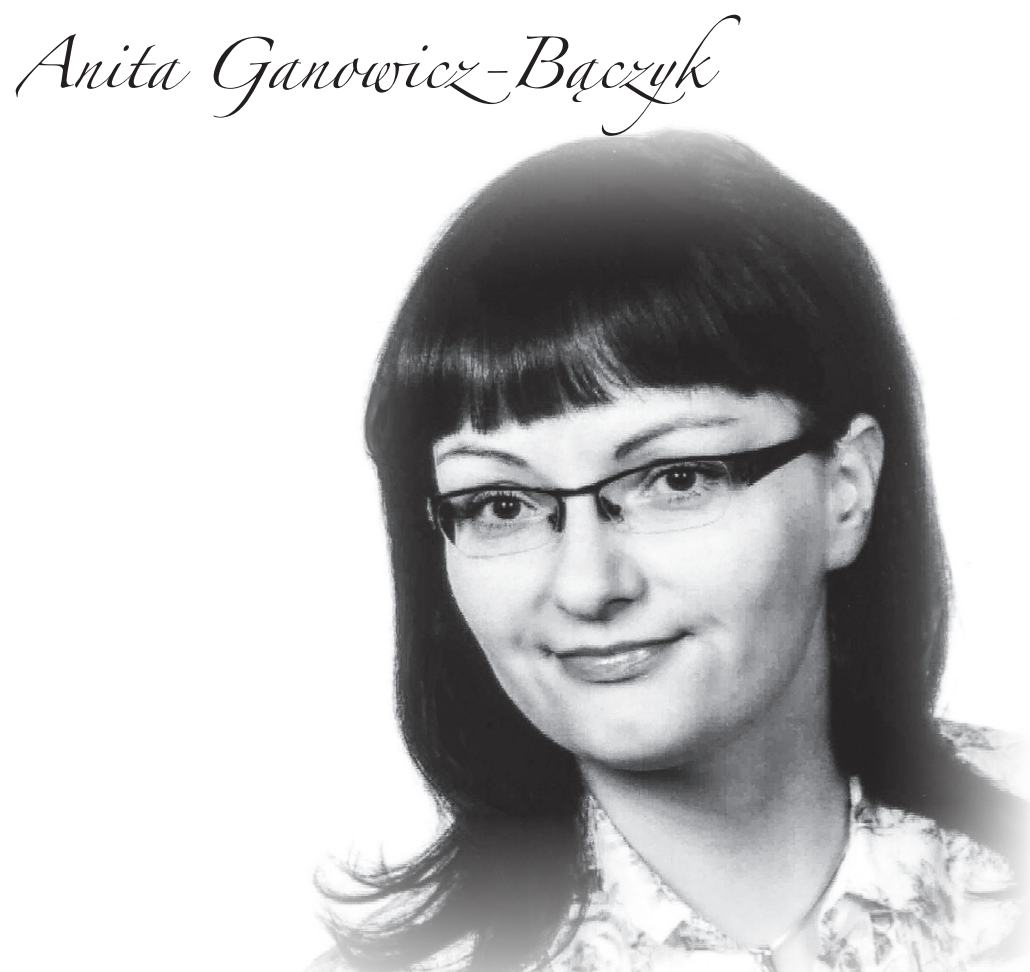

Instytut Ekologii i Bioetyki,

Uniwersytet Kardynała Stefana Wyszyńskiego w Warszawie. Zainteresowania naukowe: etyka środowiskowa, ekofilozofia, antropologia filozoficzna, filozofia przyrody. Zainteresowanie podstawami, na jakich możliwe byłoby zbudowanie holistycznej i uniwersalnej etyki środowiska naturalnego, sposobami postrzegania i kształtowania relacji człowieka $\mathrm{z}$ przyrodą $\mathrm{w}$ dziejach gatunku ludzkiego, problematyką powstania gatunku ludzkiego i wyjątkowości człowieka w świecie przyrody. Ważniejsze publikacje: Spór o etykę środowiskowa, Kraków 2009; Systemowe ujęcie biosfery w etyce Edwarda Goldsmitha, „Studia Ecologiae et Bioethicae” 12(2014)1, s. 93 -

115; Wptyw nowożytnego antropocentryzmu na relację człowieka do przyrody. Część

1, „Studia Ecologiae et Bioethicae” 9(2011)1, s. 9-27; Wpływ nowożytnego antropocentryzmu na relację człowieka do przyrody. Część 2, „Studia Ecologiae et Bioethicae" 9(2011)2, s. 9-21; Średniowieczne źródła antropocentryzmu, „Studia Ecologiae et Bioethicae” 9(2011)3, s. 21-34; Starożytne źródła antropocentryzmu, „Studia Ecologiae et Bioethicae” 7(2009)2, s. 31-38. 


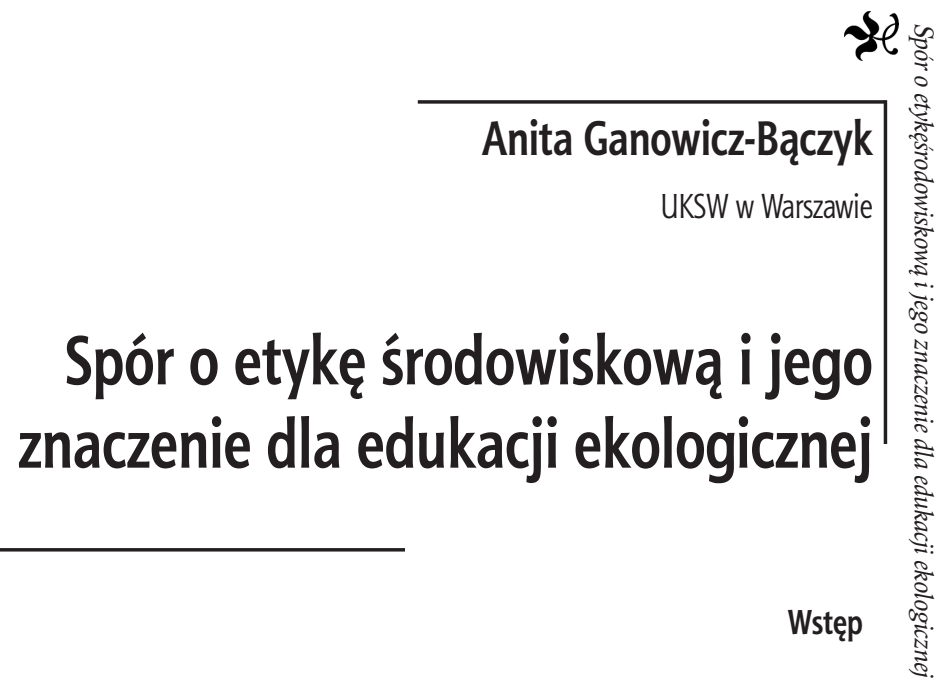

Etyka środowiskowa stanowi próbę regulacji na płaszczyźnie moralnej odniesień człowieka do pozaludzkiej przyrody. Jako taka może stanowić istotne wsparcie dla wszelkiego rodzaju działań nakierowanych na kształtowanie ludzkich postaw w stosunku do środowiska, w tym dla edukacji ekologicznej na wszystkich poziomach. Etyka środowiskowa, jak każda praktyczna filozofia, u swych podstaw ma określoną ontologię przyrody oraz konkretną koncepcję człowieka. Stąd czerpie sposób uzasadniania powinności ludzkich wobec środowiska przyrodniczego. Prawdziwość takiego działania (w rozumieniu Arystotelesa) tkwi więc w adekwatnym do rzeczywistości obrazie świata i człowieka. Błędna wiedza prowadzi bowiem do błędnego postępowania, włączając działania destrukcyjne dla człowieka i środowiska. Papież Jan Paweł II określił taką błędną wiedzę mianem błędu antropologicznego. Błąd ten jest wskazywany jako główna przyczyna niszczenia środowiska przyrodniczego i ludzkiego - społeczno-kulturowego ${ }^{1}$.

W ramach etyki środowiskowej wyróżnić można kilka nurtów, każda z tych propozycji bazuje na określonej ontologii i antropologii. W ramach niniejszego opracowania uwaga zostanie skupiona na omówieniu sporu dwóch stanowisk: antropocentrycznego i biocentrycznego oraz ukazaniu doniosłego znaczenia jego rozwiązania dla skuteczności edukacji ekologicznej. Przeciwstawieniu i analizie poddane zostaną poglądy dwojga polskich filozofów i etyków środowiskowych: Tadeusza Ślipki i Zdzisławy Piątek. Oba stanowiska wprowadzają wartościowe wskazówki dla etycznego ure-

\footnotetext{
1 Por. Jan Paweł II, Encyklika „Centesimus annus” (1 maja 1991), nr 37.
} 
gulowania relacji człowieka z przyrodą. Dlatego ukazane zostaną ich mocne strony, które dobrze uzasadniona etyka środowiskowa powinna zawsze brać pod uwagę. Dyskusji poddane zostaną też te poglądy, które należałoby zrewidować. Na tej podstawie zaproponowane zostaną postulaty do uwzględnienia zarówno w ramach etyki środowiskowej, jak i edukacji ekologicznej.

\section{Stanowiska sporu o charakter etyki środowiskowej}

$\mathrm{Na}$ wstępie należy zdefiniować, na czym polegają w swej istocie postawy antropocentryczne, a na czym biocentryczne.

Antropocentryzm to pogląd lub postawa uznająca człowieka za główny punkt odniesienia w świecie, tzn. za centrum istnienia, poznania i wartościowania ${ }^{2}$. W etyce środowiskowej antropocentryzm oznacza uznawanie, że ludzkie interesy, dobra, wartości są głównym punktem odniesienia wszelkich wartościowań moralnych i są ważniejsze niż analogiczne potrzeby istot pozaludzkich ${ }^{3}$. Rozróżnia się:

1. Antropocentryzm mocny (bezwzględny) - pogląd uznający, że tylko człowiek ma wartość wewnętrzną, natomiast zarówno inne gatunki, jak i cała planeta mają jedynie wartość utylitarną dla realizacji jego celów. Ochrona środowiska ma służyć ochronie gatunku ludzkiego i powinna prowadzić do szybko obserwowalnych (ale i krótkoterminowych) korzyści dla ludzi ${ }^{4}$ (tzw. homocentryzm - ludzki szowinizm gatunkowy). Antropocentryzm mocny był charakterystycznym elementem filozofii europejskiej co najmniej od czasów nowożytnych i jest obecny implicite w etykach tradycyjnych, m.in. Immanuela Kanta i Jean'a Paul'a Sartre’a.

2. Antropocentryzm słaby (umiarkowany, względny) - pogląd uznający, że zarówno człowiek, jak i inne istoty żywe oraz środowisko posiadają wartość wewnętrzną, jednak wartość człowieka jest nieporównanie wyższa niż reszty przyrody. Człowiek ma prawo do zabezpieczania podstawowych swoich potrzeb, tj. pożywienia, wody, schronienia, warunków sanitarnych,

2 Por. A. Podsiad, Słownik terminów i pojęć filozoficznych, Wydawnictwo PAX, Warszawa 2000, s. 48; Antropocentryzm, w: Encyklopedia PWN PL, <http://encyklopedia.pwn.pl/haslo/ antropocentryzm;3869980.html>, (data dostępu: 5.05.2014).

3 Por. E. Katz, A Pragmatic Reconsideration of Anthropocentrism, „Environmental Ethics” 21(1999), s. 377-378; E. Katz, L. Oechsli, Moving Beyond Anthropocentrism, „Environmental Ethics" 15(1993), s. 50.

${ }_{4}^{4}$ Por. G. Forbes, A Japanese Framework for Environmental Protection, <http:// www.k-junshin.ac.jp/ juntan/libhome/bulletin/No35/forbes.pdf>, (data dostępu: 26.09.2006). 
ochrony zdrowia i edukacji, ale ich realizacja nie powinna wpływać destrukcyjnie na zdrowie i integralność ekosystemów ${ }^{5}$.

Wśród reprezentantów antropocentrycznych etyk środowiskowych wymienić należy: Bryana Nortona ${ }^{6}$, Johna Passmore'a ${ }^{7}$ i Tadeusza Ślipkę

Przedstawiciele słabego antropocentryzmu deklarują, że uzdrowienie moralnych odniesień człowieka do przyrody można osiągnąć w ramach odpowiednio zmodyfikowanych tradycyjnych etyk. Wskazując na godność ludzką, wyjątkowość człowieka w świecie przyrody i upatrując w tych cechach ratunku dla natury, postulują korektę dotychczasowego kierunku myślenia. Natomiast przedstawiciele nurtów pragnących zerwać $\mathrm{z}$ tradycyjnym, antropocentrycznym podejściem do przyrody, podejmują próbę przekonania społeczeństw do całkowitego przeorientowania sposobu myślenia o świecie, przyjęcia nowego anty-antropocentrycznego światopoglądu, który jako jedyny miałby uchronić życie na Ziemi przed niszczycielską i bezmyślną działalnością ludzi. Dlatego biocentryzm uznaje się za przeciwieństwo antropocentryzmu.

Biocentryzm to pogląd uznający, że wszystkim istotom żywym przysługuje przyrodzona i/lub wewnętrzna wartość (ang. inherent/intrinsic value $^{9}$. Zgodnie z nim, wszystkie organizmy żywe stanowią punkt odniesienia dla wartościowania moralnego, uznawania ich sensu, celu i wartości. Wszystkie składniki biosfery mają równe prawo do życia, rozwoju i samorealizacji jako części jednej całości żyjące w sieci wzajemnych powiązań. $\mathrm{W}$ ten sposób biocentryzm włącza w krąg odniesień moralnych całą biosferę ${ }^{10}$.

Rozróżnia się biocentryzm słaby i mocny. W biocentryzmie słabym (hierarchicznym) wartość istot żywych jest zróżnicowana ze względu na zakres świadomości posiadania własnego dobra, celów czy interesów, dlatego ostatecznie dobro ludzkie jest wartością najwyższą. W biocentryzmie moc-

\footnotetext{
5 Por. tamże.

6 B. G. Norton, Environmental Ethics and Weak Anthropocentrism, „Environmental Ethics” 6(1984), s. 131-148.

7 J. Passmore, Man's Responsibility for Nature: Ecological Problems and Western Traditions, Charles Scribner's Sons, New York 1974.

8 T. Ślipko, A. Zwoliński, Rozdroża ekologii, Wydawnictwo WAM, Kraków 1999.

9 Por. Z. Wróblewski, Ekologii filozofia, w: Powszechna Encyklopedia Filozofii, red. A. Maryniarczyk, t. 3: E-Gn, Polskie Towarzystwo Tomasza z Akwinu, Lublin 2002, s. 75.

10 Por. tamże; N. Vonnahme, Christian Environmental Ethics, <http://enteuxis.org/nathan/ portfolio/writing/1999/xian_environmental_ethics.html>, (data dostępu: 5.06.2006).
} 
nym (egalitarnym) realizacja życia każdego gatunku ma taką samą wartość (tzw. szowinizm biocentryczny) ${ }^{11}$.

Autorzy biocentryczni to m.in. Paul W. Taylor ${ }^{12}$, Robin Attfield ${ }^{13}$ i Zdzisława Piątek ${ }^{14}$.

W sposób antropocentryczny relację człowiek-przyroda rozpatruje Tadeusz Ślipko. Jego stanowisko powstało na bazie wpisującej się w nurt tradycji chrześcijańskiej filozofii augustyńsko-tomistycznej. Ma to decydujące znaczenie dla przyjmowanej przez autora koncepcji człowieka jako istoty cielesno-duchowej, rozumnej i wolnej, stworzonej przez Boga i przewyższającej swą osobową godnością wartość innych bytów przyrodni$\mathrm{czych}^{15}$. W globalnym ujęciu jest to wizja teocentryczna całej rzeczywistości, tej materialnej i niematerialnej. Natomiast jej antropocentryzm odnosi się do porządku bytów przyrodniczych, w którym człowiek ma hierarchiczne pierwszeństwo, wyższość nad resztą widzialnego świata. Pierwszeństwo to nie opiera się jednak na zasadzie dominacji, ale włodarstwa i zarządzania przyrodą. Dlatego T. Ślipko proponuje ten pogląd nazwać „antropoprioryzmem"16, „etyką prymatu” lub „priorytetu człowieka nad przyrodą"17.

Chrześcijańska etyka priorytetu człowieka nad przyrodą uznaje więc wyższość człowieka nad przyrodą, która jednakże posiada autonomiczną, wsobną, wewnętrzną i niezależną od ludzkich ocen wartość. Dlatego przyroda powinna być przyporządkowana człowiekowi jedynie w ta-

11 Por. A. Melin, "Reflective equilibrium" as a Method for Analyzing the Dilemma of Assessing Environmental Impacts - an analysis of ElAs in the catchment area of Emån, <http://www. nordregio.se/Files/r003melin.PDF>, (data dostępu: 26.09.2006).

12 P. W. Taylor, Respect for Nature. A Theory of Environmental Ethics, Princeton-New Jersey 1986.

13 R. Attfield, Biocentrism. Moral Standing and Moral Significance, „Philosophica” 39(1987),

s. 47-58.

14 Z. Piątek, Etyka środowiskowa. Nowe spojrzenie na miejsce człowieka w przyrodzie, Wydawnictwo UJ, Kraków 1998.

15 Por. T. Ślipko, Ekologia między filozofią i ideologią, w: Między filozofią przyrody a ekofilozofią, red. A. Latawiec, Wydawnictwo Uniwersytetu Kardynała Stefana Wyszyńskiego, Warszawa 1999, s. 173; tenże, Godność człowieka w etycznym aspekcie, w: Stwarzanie i ewolucja, red. J. Buczkowska, A. Lemańska, Wydawnictwo Uniwersytetu Kardynała Stefana Wyszyńskiego, Warszawa 2002, s. 134-135; tenże, Prawo naturalne jako podstawa szacunku człowieka dla życia i przyrody, „Ethos” (1994)25/26, s. 95-97; tenże, Antropologiczne wymiary problemu ekologicznego, „Universitas” (1995)2-3, s. 94.

16 Por. tenże, Ekologia między filozofią i ideologią, art. cyt., s. 176-177 i 187.

17 Por. T. Ślipko, A. Zwoliński, Rozdroża ekologii, dz. cyt., s. 132-133. 
kim stopniu, w jakim okazuje się to konieczne do realizacji jego moralnych przeznaczeń. Przyroda stwarza bowiem warunki nie tylko do egzystencji człowieka, ale także do realizacji jego powołania - jego moralnego rozwoju.

Antropologia chrześcijańska mówi wyraźnie o powołaniu człowieka do nieustannego rozwoju moralnego i osobowego, „do dźwigania własnego jestestwa na coraz wyższe szczeble człowieczeństwa aż do dostępnych mu szczytów doskonałości"18. Człowiek powinien zatem używać wolności tak, aby działania jego były zgodne z moralnym sensem. Dopiero takie działanie jest działaniem w pełni ludzkim, godnym człowieka jako osoby ${ }^{19}$.

Ślipko w zdecydowany sposób przeciwstawia się koncepcji dominacji człowieka nad przyrodą ${ }^{20}$, gdyż obraz człowieka jako „pana natury” jest zaprzeczeniem autentycznego chrześcijaństwa ${ }^{21}$, zaś dewastowanie przyrody stanowi naruszenie chrześcijańskich zasad moralnych ${ }^{22}$.

Tadeusz Ślipko podkreśla, że człowiek ma obowiązek uszanowania i zachowania moralnego ładu względem przyrody i choć posiada on prawo do wolności, postępu i opanowania przyrody to prerogatywy te są ograniczone $^{23}$. Prawa i obowiązki człowieka względem przyrody należy ujmować integralnie oraz liczyć się z wzajemnym ograniczaniem się zakresów ich moralnego obowiązywania. Człowiekowi bowiem została powierzona przez Boga misja zarządzania i gospodarowania darem stworzenia w granicach porządku moralnego.

W sferze powiązań z przyrodą Ślipko zauważa trzy dziedziny aktywności twórczej człowieka: I. dziedzina symbiozy człowieka z przyrodą, II. dziedzina produkcji: pracy i przeobrażeń przyrody, III. dziedzina duchowej kontemplacji walorów przyrody. Wszystkie te dziedziny domagają się zrównoważonego udziału w ludzkich poczynaniach ${ }^{24}$.

\footnotetext{
18 T. Ślipko, Godność człowieka w etycznym aspekcie, art. cyt., s. 141.

19 Por. tenże, Etyczne motywacje działań ekologicznych (1), „Materiały problemowe” 21(1989)7-8, s. 100.

20 Por. T. Ślipko, A. Zwoliński, Rozdroża ekologii, dz. cyt., s. 132-133.

21 Por. T. Ślipko, Ekologia między filozofią i ideologią, art. cyt., s. 175; tenże, Podstawy etyki środowiska naturalnego, „Chrześcijanin w świecie” 139(1985)4, s. 60-61.

${ }^{22}$ Por. tenże, Recenzja: M. Volf, Zukunft der Arbeit - Arbeit der Zukunft. Der Arbeitsbegriff bei Karl Marks und seine theologische Wertung, München Kaiser-Mains Gümewald 1988, „Studia Philosophiae Christianae” 27(1991)1, s. 191.

${ }^{23}$ Por. tenże, Etyczne motywacje działań ekologicznych (1), art. cyt., s. 99.

${ }^{24}$ Por. tamże, s. 100; tenże, Podstawy etyki środowiska naturalnego, art. cyt., s. 63.
} 
Zdaniem autora, formowanie motywacji etycznych na rzecz ochrony przyrody powinno opierać się na cnocie pokory i miłości oraz poczuciu odpowiedzialności, a odbywać się może m.in. poprzez uświadomienie człowiekowi, że przyroda jest darem od Boga dla jego dobra, odgrywa rolę w kształtowaniu jego kultury duchowej, zaś bytowo jest odblaskiem odwiecznego piękna ${ }^{25}$. Zaproponowana przez Tadeusza Ślipkę etyka prymatu człowieka nad przyrodą wyraźnie pokazuje wyjątkowość człowieka wśród wszystkich istot żywych na Ziemi. Akcentuje powołanie człowieka do osobowego rozwoju i odpowiedzialności. Są to niewątpliwe zalety prezentowanego stanowiska. $Z$ drugiej strony, pewne twierdzenia budzą wątpliwości i domagają się rewizji bądź dopracowania.

Do słabych punktów etyki prymatu należy szczególnie nieufność wobec wiedzy o przyrodzie niesionej przez nauki szczegółowe. Wyraża się ona w dość okrojonym obrazie rzeczywistości przyrodniczej oraz niepełnym zrozumieniu zależności i praw nią rządzących. Szczególnie wyraźnie sugerowane jest to przez swoiste niedowierzanie, że teoria o zachodzeniu procesu ewolucji w rozwoju przyrody ożywionej w sposób sensowny i adekwatny opisuje fenomen człowieka. Ślipko notorycznie podkreśla różnice i priorytet człowieka nad resztą przyrody i wykazuje daleko idącą wrażliwość na jakiekolwiek sugestie dowartościowania pozaludzkich istot żywych czy zmniejszenia dystansu, rozziewu między człowiekiem a innymi zwierzętami. Współczesna wiedza o człowieku wskazuje zaś wyraźnie na ścisłe pokrewieństwo człowieka z innymi gatunkami. Psychiczna warstwa człowieka oraz całe jego genetyczne wyposażenie, wiążą go ze światem animalnym. Ponieważ psychika człowieka związana jest z jego skłonnościami naturalnymi, odpowiadającymi genetycznie zaprogramowanym sposobom zachowania się, nie stanowi ona o wyjątkowości człowieka w świecie przyrody. Decyduje o niej zaś ludzki duch ${ }^{26}$, rozumność, samoświadomość, wolność, refleksyjność, zdolność do kierowania się przyjętymi celami i wartościami - nawet wbrew wrodzonym wartościom emocyjnym, zdolność do

\footnotetext{
25 Por. tenże, Etyczne motywacje działań ekologicznych (1), s. 102; tenże, Czym są i gdzie bytują obiektywne wartości moralne, „Etyka” 30(1997), s. 109.

${ }^{26}$ Por. Z. Łepko, Etologiczna teoria destrukcji człowieczeństwa, w: Człowiek w czasie i przestrzeni. Księga pamiątkowa z okazji 70. rocznicy urodzin Księdza Profesora Bernarda Hałaczka, red. J. Tomczyk, A. Abdank-Kozubski, Wydawnictwo Uniwersytetu Kardynała Stefana Wyszyńskiego, Warszawa 2006, s. 76.
} 
bezinteresownego altruizmu ${ }^{27}$, zdolność do nonkonformizmu i niepoddawania się dyktatowi zarówno zaprogramowania genetycznego (tzw. zasadzie zwiększania dostosowania, maksymalizacji fitness), jak i zaprogramowania kulturowego (indoktrynacji). Na styku biologii i kultury, jak wskazuje Tadeusz Bielicki, znajduje się bowiem strefa indywidualnej wolności wyboru ${ }^{28}$.

Jednakże wszystkie wymienione zdolności człowieka zakorzenione są w nim jako istocie ożywionej. Neurologia wskazuje wyraźnie na ewolucyjne pochodzenie wysoce skomplikowanego w budowie ludzkiego mózgu, którego ewolucja umożliwiła powstanie samoświadomego ducha i myślowe przekraczanie przez człowieka świata materii i energii (tzw. dowieczność), a z drugiej strony zachowała zdeterminowane biologicznie emocje i wzory zachowań charakterystyczne również dla innych zwierzą ${ }^{29}$. Wydaje się, że bezkompromisowe podkreślanie różnic między człowiekiem a innymi istotami żywymi i rozdzielanie ludzkości od przyrody niesie ze sobą - wbrew intencjom autora - ryzyko tzw. „szowinizmu gatunkowego”.

W sposób krytyczny wobec etyk antropocentrycznych odnoszą się rzecznicy biocentrycznej etyki środowiskowej. Na przykład Zdzisława Piątek krytykuje paradygmat antropocentryczny wyrażający się w przekonaniu, że tylko istoty ludzkie mają wartość wewnętrzną, człowiek jest miarą wszechrzeczy, zaś przyroda została stworzona lub wyewoluowała dla człowieka i jego celów. Są one dla niej przejawem homocentryzmu, czyli ludzkiego szowinizmu gatunkowego ${ }^{30}$. To aroganckie uleganie „iluzji wielkości” oraz ignorancja oraz redukcjonizm w zakresie wiedzy przyrodniczej stanowią zasadnicze przyczyny kryzysu ekologicznego ${ }^{31}$. Najwyższą wartością w biocentryzmie jest dobro każdej żyjącej istoty ${ }^{32}$.

${ }^{27}$ Por. T. Bielicki, Natura ludzka: jaka jest - i czy jest?, „Problemy” 9(1989), s. 7-8; A. Wierciński, O osobliwości natury gatunkowej człowieka, „Kosmos” 1(1990), s. 119.

28 Por. T. Bielicki, Pojęcie natury ludzkiej w świetle biologicznej teorii zachowań społecznych, w: Dylematy współczesnej cywilizacji a natura człowieka, red. J. Reykowski, T. Bielicki, Zysk i S-ka, Poznań 1997, s. 23-24; T. Bielicki, Natura ludzka: jaka jest - i czy jest?, art. cyt., s. 7.

${ }_{29}$ Por. T. Wojciechowski, Wybrane zagadnienia z filozoficznej antropologii, Polskie Towarzystwo Teologiczne, Kraków 1985, s. 25-33 i 42.

30 Por. Z. Piątek, Biocentrism as a Proposition for New Thinking about the Biosphere, <http:// www.biopolitics.gr/HTML/PUBS/VOL6/HTML/piatek.htm>, (data dostępu: 7.06.2006).

${ }^{31}$ Por. taż, Etyka środowiskowa, dz. cyt., s. 45, 114.

32 Por. T. Shinagawa, Nature, Environment, and Human Being: Hans Jonas on the Principle of Responsibility, <http://www2.ipcku.kansai-u.ac.jp/ tsina/NEH.pdf>, (data dostępu: 5.06.2006). 
Piątek zauważa, że źródłem antropocentryzmu i antropocentrycznych deformacji rzeczywistości są naturalne ograniczenia ludzkiego poznania (tzw. antropocentryzm podmiotowy). Człowiek nie jest jednak wobec nich bezbronny. Samoświadomość daje mu możliwość podejmowania wysiłków mających na celu pokonanie zniekształceń i ograniczeń poznawczych. Przykładem takich wysiłków są nauki przyrodnicze i filozofia, które dążą do uzyskania w procesie poznania jak najbardziej obiektywnego obrazu świata (tzw. antropocentryzm krytyczny, dla Z. Piątek tożsamy z anty-antropocentryzmem $)^{33}$. Z kolei, szeroko pojęta humanistyka, jako dotycząca świata ludzkich przeżyć, doznań i wartości, z założenia jest i powinna być antropocentryczna. W tym tkwi jej istota ${ }^{34}$.

Biocentryczna etyka środowiskowa obficie korzysta z wiedzy dostarczanej przez nauki przyrodnicze. Obraz świata wyłaniający się z tych nauk skłania do odrzucenia w relacjach człowiek-przyroda ludzkiego szowinizmu gatunkowego (homocentryzmu) oraz zastąpienia go biocentrycznym paradygmatem gatunkowej bezstronności ${ }^{35}$.

Biocentryzm odrzuca hierarchiczną drabinę bytów i zamiast niej proponuje obraz przyrody jako drzewa i sieci wzajemnych zależności. Kluczowa jest teza, że gatunek ludzki stanowi jeden z niezliczonej ilości gatunków istot zamieszkujących Ziemię i z punktu widzenia ekologii nie jest ani gatunkiem bardziej wyjątkowym, ani niezbędnym dla biosfery („detronizacja" człowieka jako korony stworzenia). Pomiędzy człowiekiem a innymi gatunkami istot żywych nie istnieje żadna przepaść. Wszystkie organizmy są spokrewnione i powiązane siecią skomplikowanych, wzajemnych zależności. Gatunek ludzki jest takim samym członkiem ziemskiej biosfery jak inne gatunki istot żywych i stanowi integralną część jej naturalnego ładu. Pojawienie się człowieka nie było wcześniej wyróżnionym punktem kulminacyjnym ani celem ostatecznym trwającego nadal procesu ewolucji. Co więcej, Ziemia i biosfera mogą istnieć bez człowieka, natomiast gatunek ludzki nie może istnieć niezależnie od ich istnienia. Bezstronność gatunkowa domaga się podobnego traktowania miejsca i sposobu egzystencji gatunku ludzkiego, jak dowolnego innego gatunku. Ludzie nie mogą z tytułu „swojej inności”,

33 Por. Z. Piątek, Aspekty antropocentryzmu, Wydawnictwo Uniwersytetu Jagiellońskiego, Kraków 1988, s. 16 i 22; taż, Etyka środowiskowa, dz. cyt., s. 59, 63-65, 77, 80 i 90.

34 Por. taż, Aspekty antropocentryzmu, dz. cyt., s. 17-18, 47 i 113.

${ }_{35}$ Por. taż, Filozoficzne korzenie kryzysu środowiskowego, w: Człowiek i środowisko. Humanistyka i ekologia, red. J. Dębowski, Wyższa Szkoła Pedagogiczna, Olsztyn 1995, s. 47. 
polegającej m.in. na posiadaniu rozumu i wolnej woli, uznawać swej egzystencji za bardziej wartościową niż egzystencja innych istot żywych (tzw. równość biocentryczna) ${ }^{36}$. Zachowanie bioróżnorodności jest również wartością samą w sobie, gdyż stanowi warunek sine qua non wszelkiego życia.

Z. Piątek przyznaje, że „podmiotem moralności mogą być jedynie samoświadome, wolne i odpowiedzialne istoty ludzkie" ${ }^{\prime 37}$, czyli osoby. Ponieważ jednak każda istota żywa posiada potrzeby, cele życiowe i „interesy”, w związku z czym realizuje własne dobro na miarę swojego gatunku i jest podmiotem lepszej lub gorszej jakości życia, dlatego należy obiektywnie uznać wartość wewnętrzną bytów ożywionych, włączyć je do uniwersum moralności i traktować jak przedmioty moralności człowieka. Takie poszerzenie zakresu moralności człowieka skutkuje tym, że wszyscy ludzie mają obowiązek protegować i ochraniać dobro istot żywych jako cel sam w sobie $^{38}$ oraz szanować naturalne mechanizmy przyrody, dzięki którym życie powstało, trwa i ewoluuje.

Dla zażegnania sytuacji kryzysowej konieczne są, zdaniem Piątek, wiedza, moralność, dobra wola, racjonalne działanie oraz zrównoważenie rozwoju cywilizacyjnego. Pojęcie zrównoważonego rozwoju Z. Piątek odnosi do „zespołu mechanizmów umożliwiających taką organizację ludzkiego świata, aby mógł on harmonijnie i trwale współistnieć z biosferą, umożliwiając samorealizację człowieka” ${ }^{39}$. Akcentuje ona, że „rozwój zrównoważony, który w biosferze jest osiągany za pośrednictwem mechanizmów biologicznych, w rozwoju antroposfery musi być osiągnięty przy pomocy celowego działania" ${ }^{40}$. Koncepcja zrównoważonego rozwoju jest więc pierwszą w historii życia na Ziemi świadomie i celowo określoną próbą uniknięcia samozagłady ${ }^{41}$.

${ }^{36}$ Por. taż, Etyka środowiskowa, dz. cyt., s. 14, 80-81; taż, Dylematy etyki środowiskowej, w: Ekofilozofia i bioetyka, red. W. Tyburski, TOP Kurier, Toruń 1996, s. 55-56; taż, Etyka życia, w: Etyka. Zarys, red. J. Pawlica, Wydawnictwo Uniwersytetu Jagiellońskiego, Kraków 1992, s. 109.

${ }_{37}$ Z. Piątek, Dylematy etyki środowiskowej, art. cyt., s. 43.

38 Por. taż, Etyka środowiskowa, dz. cyt., s. 79-80.

${ }^{39}$ Taż, Człowiek jako podmiot zrównoważonego rozwoju: konsekwencje filozoficzno-społeczne, w: Zrównoważony rozwój. Od utopii do praw człowieka, red. A. Papuziński, Wydawnictwo Branta, Bydgoszcz 2005, s. 16.

40 Tamże, s. 14.

41 Por. tamże, s. 16, 18-19; taż, Filozoficzne podłoże zrównoważonego rozwoju, „Problemy Ekorozwoju” 2(2007)1, s. 6-7; taż, Postawy światopoglądowe a ryzyko dewastacji naturalnego środowiska, „Universitas” (1995)2-3, s. 26. 
Etyka biocentryczna niesie ze sobą niewątpliwe walory, uwydatniając szczególną wartość ożywionej przyrody, ukazując jej złożoność i zwracając uwagę na skomplikowane, niezrozumiałe dla człowieka zależności. W tym zakresie stanowi istotne uzupełnienie obrazu niesionego przez etykę prymatu człowieka nad przyrodą. Nie jest jednak pozbawiona słabych stron. Przede wszystkim charakterystyczne jest dla niej nie do końca adekwatne ujęcie człowieka jako osoby, a co za tym idzie, niewyciąganie z faktu bycia przez człowieka istotą moralną właściwych wniosków: konsekwentnie biocentryczna etyka środowiskowa nie jest możliwa do realizacji, jeśli traktuje się człowieka i inne istoty żywe w równy sposób. Tylko zwiększone wymagania wobec człowieka dają szansę na uzdrowienie ludzkich relacji z przyrodą - a te zakładają krytyczny antropocentryzm (ale nie anty-antropocentryzm).

Uwagę zwraca także arbitralność biocentryzmu w zakresie określania i uzasadniania, co posiada wartość wewnętrzną i z tego tytułu stanowi przedmiot moralny, tzn. wyłączenie z zakresu przedmiotów moralności bytów nieożywionych (tzw. szowinizm biocentryczny). A także indywidualistyczny charakter dyskutowanej etyki, która koncentruje się na dobru indywidualnych osobników, nie doceniając wartości, dobra własnego i znaczenia ekosystemów.

\section{Wytyczne dla etyki środowiskowej}

W związku z tym, że żadna $\mathrm{z}$ dyskutowanych etyk nie jest wolna od błędów, konieczne wydaje się sformułowanie zasad, jakimi powinna kierować się adekwatna etyka środowiskowa. Etyka taka powinna uwzględniać z jednej strony osobową specyfikę bytu ludzkiego, z drugiej zaś wartość niezależnej od niego w istnieniu przyrody.

Należy w tym miejscu wskazać na daleko idące podobieństwa między słabym biocentryzmem i słabym antropocentryzmem. Oba stanowiska zgodnie uznają, że przyroda ma wartość wewnętrzną, niezależną od ludzkich wartościowań. Słabemu biocentryzmowi bliżej jest nawet do słabego antropocentryzmu niż do silnego biocentryzmu. $Z$ kolei słabemu antropocentryzmowi bliżej do słabego biocentryzmu niż do silnego antropocentryzmu. Dlatego - z praktycznego punktu widzenia - obojętne jest, który pogląd uznajemy, gdyż konsekwencje obu są zbliżone. Autorzy tacy jak 
E. Harlow ${ }^{42}$, B. G. Norton ${ }^{43}$ uważają, że niezależnie od tego, czy przyroda jest wartościowa wewnętrznie, czy nie, dla etyki środowiskowej nie ma to decydującego znaczenia. Jak pisze Stefan Pikus, „dla osiągnięcia długofalowego celu, jakim jest i powinno być zachowanie gatunku ludzkiego i sprzyjających człowiekowi warunków życia na Ziemi jest obojętne, czy ludzie będą chronić przyrodę ze względu na nią samą (np. dla zachowania jej stabilności, integralności i piękna - jak postulują reprezentanci holistycznej odmiany etyki środowiskowej), czy ze względu na żywiony respekt dla $\mathrm{Na}-$ tury (co postulują teoretycy biocentrycznej odmiany etyki środowiskowej), czy wreszcie - ze względu na ratowanie życia ludzkiego (co postulują reprezentanci antropocentrycznego kierunku etyki środowiskowej)"44.

Wydaje się, że w warstwie światopoglądowej nie można jednak zrezygnować zupełnie z postawy antropocentrycznej. Jest ona wyrazem naturalnego dla człowieka sposobu odbioru i interpretacji rzeczywistości, jest nieodzowna w stosunkach międzyludzkich, bez niej nie jest możliwe tworzenie kultury, doskonale uzasadnia powinności moralne człowieka - podmiotu moralnego - wobec przyrody, w której moralności jako takiej nie ma, zaś w postaci słabego antropocentryzmu - jak pokazuje B. G. Norton ${ }^{45}$ - dobrze spełnia swoje zadanie odnośnie do relacji człowiek-przyroda. Należy przy tym złagodzić umiarkowany antropocentryzm akcentami nieantropocentrycznymi, czerpanymi z etyk holistycznych i systemowych (wartościujących całe ekosystemy), a nie z biocentrycznych i indywidualistycznych.

Kryzys ekologiczny grozi nie tylko spustoszeniem środowiska przyrodniczego, nie tylko biologicznemu przetrwaniu człowieka, ale także zagraża destrukcją człowieczeństwa w jego psychicznym i duchowym wymiarze. Wskazuje mianowicie na ścisłą zależność kondycji psychicznej i wrażliwości człowieka na piękno od jakości ekologicznej środowiska oraz pozwala dostrzec zagrożenie destrukcją estetycznej struktury i psychicznej kondycji człowieka. Poziom estetycznej wrażliwości człowieka stanowi podstawę dla etycznych doświadczeń człowieka, tzn. warunkuje poziom

\footnotetext{
${ }^{42}$ E.M. Harlow, The Human Face of Nature: Environmental Values and the Limits of Nonanthropocentrism, „Environmental Ethics” 14(1992), s. 27-42.

43 B.G. Norton, Environmental Ethics and Weak Anthropocentrism, „Environmental Ethics” 6(1984), s. 131-148.

${ }^{44}$ S. Pikus, Moralne aspekty ochrony środowiska przyrodniczego, Wyższa Szkoła Pedagogiczna w Słupsku, Słupsk 1997, s. 66.

45 B. G. Norton, The Constancy of Leopold's Land Ethic, „Conservation Biology 2” 1(1988), s. $94-100$.
} 
jego szacunku i podziwu wobec przyrody ${ }^{46}$. Drastycznie ograniczony dopływ informacji o pięknie przyrody prowadzi więc często do upośledzenia zdolności odróżniania tego, co dobre, od tego, co złe w działaniach odnoszących się do środowiska. Ostatecznie wiedzie zaś do alienacji człowieka ze środowiska ${ }^{47}$.

Ponieważ kryzys ekologiczny prowadzi zarówno do dewastacji przyrody, jak i do degradacji człowieczeństwa, poszukuje się dróg jego przezwyciężenia. Według K. Lorenza, skutecznym środkiem przeciwko narastającej dehumanizacji jest odpowiednie wychowanie i edukacja: do postrzegania piękna i harmonii, do współodczuwania $\mathrm{z}$ istotami żywymi, do rozpoznawania dysharmonii systemów chorych i do odrazy wobec indoktrynacji. Miłość do tego, co żyje, jest ważną i nieodzowną emocją; to ona nakłada na człowieka odpowiedzialność za działania w środowisku wobec innych istot żywych, a nawet za życie na Ziemi ${ }^{48}$. Zdaniem Hansa Jonasa, poczucie odpowiedzialności, jako ważny przejaw moralności, jest kluczowe w etyce środowiskowej i ochronie środowiska jako takiej ${ }^{49}$. Postulowana postawa wymaga więc włączenia w system wartości motywujących działania również elementów postawy nieantropocentrycznej (w odróżnieniu od postawy anty-antropocentrycznej).

\section{Wytyczne dla edukacji ekologicznej}

Wprowadzanie zasad etyki środowiskowej w praktykę życia i działania wiąże się z edukowaniem społeczeństwa. Przeprowadzona wyżej analiza prowadzi do konstatacji, że dla ukształtowania postaw prośrodowiskowych i skutecznej ochrony środowiska przyrodniczego potrzebne są, obok motywacji racjonalnych, motywacje emocjonalne, estetyczne i etyczne. Nie wystarczy samo przekazywanie wiedzy, ale chodzi przede wszystkim o bezpośrednie doświadczanie bliskiego kontaktu z przyrodą. Kształtowanie

46 Por. Z. Łepko, W sprawie ekologicznej estetyki przyrody, „Studia Ecologiae et Bioethicae” 3(1994), s. 128-133; tenże, Etologiczna teoria kryzysu ekologicznego, w: Od kosmologii do ekofilozofii. Problemy filozoficzne XXI wielu, red. J. M. Dołęga, Episteme 22, Olecko 2002, s. 171-172.

47 Por. tenże, Etologiczna teoria kryzysu ekologicznego, art. cyt., s. 174-175.

48 Por. K. Lorenz, Regres człowieczeństwa, tłum. A. D. Tauszyńska, PIW, Warszawa 1986, s. $183-184$.

49 Por. H. Jonas, Zasada odpowiedzialności. Etyka dla cywilizacji technologicznej, tłum. M. Klimowicz, Wydawnictwo Platan, Kraków 1996, s. 232. 
etycznej wrażliwości człowieka na dobro innych przedstawicieli własnego gatunku oraz dobro całej biosfery wymaga całościowego ujmowania osoby ludzkiej i oddziaływania na jej wszystkie wymiary: biologiczno-fizjologiczny, psychiczno-emocjonalny i umysłowo-duchowy.

Niżej omówione zostaną czynniki wpływające na prawidłowe ukształtowanie świadomości ekologicznej. Pierwszym, podstawowym z nich, jest doświadczenie na wszystkich płaszczyznach osobistego kontaktu z przyrodą (na płaszczyźnie fizycznej, psychicznej - emocjonalnej i estetycznej, oraz duchowej) $)^{50}$. Według K. Lorenza, wychowanie ekologiczne powinno być nie tyle procesem uświadamiania, co bezpośredniego unaoczniania piękna i harmonii panującej w przyrodzie oraz kulturze. Unaocznienie warunkuje bowiem zdolność do odczuwania wartości, odkrywania sensu, do współodczuwania z innymi istotami żywymi i w konsekwencji do rozbudzenia odpowiedzialności za wszelkie przejawy życia w swoim otoczeniu ${ }^{51}$.

Drugim z czynników decydujących o kształtowaniu świadomości ekologicznej jest uznawany system wartości i norm ${ }^{52}$. Edukacja ekologiczna, w celu poszerzenia wiedzy przyrodniczej o sferę moralnych relacji człowieka ze środowiskiem, odwołuje się do problematyki etyczno-środowiskowej. Dąży tym samym do wpływania na emocje i motywacje, do kształtowania postaw i zachowań prośrodowiskowych, do wpisania formułowanego przez etykę środowiskową systemu wartości i norm do świadomości indywidualnej i społecznej ${ }^{33}$. Odwołuje się do wartości, uczuć oraz cnót ekologicznych, których realizacja sprzyja ochronie środowiska, takich jak: życie, zdrowie, piękno, harmonia, trwałość, bioróżnorodność, zmysł kontemplacji, dążenie do prawdy, dalekowzroczność, umiarkowanie (powściągliwość), oszczędność, pokora, skromność, uczciwość, odpowiedzialność, sprawiedliwość,

50 Por. W. Tyburski, Etyka i ekologia, Polski Klub Ekologiczny, Toruń 1995, s. 37.

51 Por. K. Lorenz, Regres człowieczeństwa, dz. cyt., s. 174-184.

52 Por. W. Tyburski, Aksjologiczny wymiar edukacji ekologicznej, w: Ekonomia. Ekologia. Etyka, red. W. Tyburski, Instytut Filozofii UMK, Toruń 1996, s. 109; tenże, Etyka środowiskowa - przedmiot, stanowiska i propozycje, w: Meandry etyki, red. Z. Sareło, Episteme 17, Wydawnictwo Wszechnicy Mazurskiej, Olecko 2002, s. 181.

${ }^{53}$ Por. tenże, Aksjologiczny wymiar edukacji ekologicznej, art. cyt., s. 112; tenże, Etyka środowiskowa - przedmiot, stanowiska i propozycje, art. cyt., s. 181-182; tenże, Pojednać się z Ziemią. W kręgu zagadnień humanizmu ekologicznego, IPIR, Toruń 1993, s. 97. 
wspólnotowość (solidarność), pokój ${ }^{54}$, uważność, dostrojenie, współodczuwanie, życzliwość, wdzięczność, poświęcenie i pracowitośćs ${ }^{55}$.

Trzecim istotnym składnikiem świadomości ekologicznej jest wrażliwość etyczna i estetyczna. Chodzi przede wszystkim o wrażliwość na cierpienie (empatia), na niesprawiedliwość, na piękno, na harmonię.

Kolejnym elementem składowym świadomości ekologicznej jest wiedza (często błędnie utożsamiana z samą świadomością ekologiczną). Wiedza ta dotyczy takich zagadnien, jak miejsce człowieka w przyrodzie (człowiek jako integralna część przyrody), historia rozwoju ludzkości, podstawowe prawa przyrody, procesy i relacje zachodzące w przyrodzie (człowiek mający zdolność przekształcania przyrody dzięki wykorzystaniu znajomości obowiązujących w niej praw i działaniu w zgodzie z nimi). Wiąże się ona z umiejętnością rozpoznawania stanu zdrowia środowiska, wpływu działalności człowieka na środowisko i znajomością sposobów przeciwdziałania jego negatywnym skutkom (zrównoważenie rozwoju, postawa współdziałania i opiekuństwa). Wiedza ta obejmuje również problematykę zdrowego i zrównoważonego stylu życia (zmiana konsumpcjonistycznych stylów życia na rzecz umiarkowania i powściągliwości w korzystaniu z dóbr oraz racjonalizacji potrzeb i przeciwstawiania się marnotrawstwu) $)^{56}$.

${ }^{54}$ Por. D. Liszewski, Wartości ekologiczne, w: Słownik bioetyki, biopolityki i ekofilozofii, red. M. Ciszek, Polskie Towarzystwo Filozoficzne, Warszawa 2008, s. 275; W. Tyburski, Etyka środowiskowa i jej wkład w budowanie świadomości sprzyjającej wdrażaniu idei zrównoważonego rozwoju, w: Zasady kształtowania postaw sprzyjających wdrażaniu zrównoważonego rozwoju, red. W. Tyburski, Wydawnictwo Naukowe Uniwersytetu Mikołaja Kopernika, Toruń 2011, s. 108-151; tenże, Etyka środowiskowa - przedmiot, stanowiska i propozycje, art. cyt., s. 160-177; tenże, System wartości i etyczna ochrona środowiska przyrodniczego, w: Człowiek i środowisko. Dyscypliny humanistyczne i ekologia, red. W. Tyburski, Uniwersytet Mikołaja Kopernika w Toruniu, Wojewoda Toruński, Polski Klub Ekologiczny Oddział Pomorsko-Kujawski, Toruń 1995, s. 77-84; tenże, Uniwersalny wymiar etyki ekologicznej (środowiskowej), w: Czy jest możliwa etyka uniwersalna?, red. J. Sekuła, Wydawnictwo Wyższej Szkoły Rolniczo-Pedagogicznej, Siedlce 1994, s. 378-380; tenże, Aksjologia ochrony środowiska przyrodniczego, w: Ochrona środowiska w filozofii i teologii, red. J. M. Dołęga, J. W. Czartoszewski, Wydawnictwo ATK, Warszawa 1999, s. 159-169.

55 Por. R. L. Sandler, Character and Environment. A Virtue-Oriented Approach to Environmental Ethics, Columbia University Press, New York 2008, s. 82.

56 Por. K. Biernat, Podstawy wiedzy o przyrodzie jako element poszanowania środowiska naturalnego, w: Wychowanie do poszanowania środowiska społeczno-przyrodniczego, red. J. W. Czartoszewski, J. M. Kotowski, Verbinum, Warszawa 2003, s. 115-116; B. Poskrobko, Społeczne czynniki ochrony środowiska, w: K. Górka, B. Poskrobko, W. Radecki, Ochrona środowiska. Problemy społeczne, ekonomiczne i prawne, PWE, Warszawa 2001, s. 30-31; W. Tyburski, Etyka środowiskowa - przedmiot, stanowiska i propozycje, art. cyt., s. 171-174. 
Ostatnim kluczowym elementem świadomości ekologicznej jest wyobraźnia ekologiczna. Obejmuje ona zdolność do ujmowania całościowego i systemowego relacji człowieka ze środowiskiem, umiejętność przewidywania ekologicznych skutków podejmowanych działań, jak również stosownego do tego projektowania przedsięwzięć w środowisku ${ }^{57}$.

Omówione wyżej komponenty świadomości ekologicznej są jednocześnie tymi, które - nieodpowiednio uformowane - doprowadziły do kryzysu ekologicznego. Pokazują zarazem potrzebę wielowymiarowej edukacji ekologicznej oddziałującej na każdą z płaszczyzn. Uzmysławiają również swą współzależność i współdziałanie w kształtowaniu postaw człowieka względem środowiska przyrodniczego. Wymienione bowiem elementy wzajemnie się uzupełniają i tworzą harmonijną całość ${ }^{58}$.

Oprócz wychowania i edukacji środowiskowej sensu stricto, nie mniej ważne jest wychowanie człowieka do rozwoju jego osobowych potencjalności. Chodzi przede wszystkim o wychowanie do wolności i do odpowiedzialności. Człowieka do wolności i odpowiedzialności należy bowiem wychowywać i przygotowywać. W tym zaś celu należy usprawniać zarówno jego rozum, jak i umacniać siłę jego woli ${ }^{59}$.

Wola, motywacja, postawa są szczególnie ważne, doświadczenie pokazuje bowiem, że nie zawsze wiedza o tym, co jest dobre, oznacza postępowanie w dobry sposób. Wielokrotnie ludzie postępują w sposób nieracjonalny, nieprzemyślany, podyktowany krótkowzrocznym interesem czy emocjami, potrzebą dominacji, posiadania tego, co inni i więcej niż inni. Można rzec, że bytują na poziomie bytu przyrodniczego i poza ten wymiar nie wykraczają. Działanie racjonalne, altruistyczne, niekoniecznie liczące się z własnym interesem, ale raczej szanujące potrzeby innych, działanie niekonformistyczne i wymagające wysiłku czy samopoświęcenia domaga się natomiast wykroczenia poza czysto zwierzęcą egzystencję, domaga się transcendowania własnego ,ja” oraz obiektywnego spojrzenia na rzeczywistość i własne w niej miejsce. Wymaga wiele samozaparcia, wysiłku i trudu. Stąd tak ważna jest edukacja na każdym szczeblu rozwoju człowieka, prze-

57 Por. B. Poskrobko, Społeczne czynniki ochrony środowiska, art. cyt., s. 30-31.

58 Por. W. Tyburski, Etyka środowiskowa - przedmiot, stanowiska i propozycje, art. cyt., s. 181.

59 Por. M. A. Krąpiec, Idea „postępu” w krzywym zwierciadle ekologii, „Człowiek w kulturze” 2(1994), s. 26; K. Wojtyła, Miłość i odpowiedzialność, Wydawnictwo KUL, Lublin 2010; tenże, Osoba i czyn, Wydawnictwo KUL, Lublin 2000. 
kładająca się następnie na konkretne postawy i postępowanie realizowane w życiu społecznym, politycznym czy gospodarczym.

Widać więc, że rozwój osobowy człowieka jest niezbędny nie tylko dla relacji międzyosobowych, społecznych, ale również dla budowy prawidłowych relacji ze środowiskiem przyrodniczym. Staje się to jeszcze bardziej oczywiste w świetle badań A. Maslowa nad cechami specyficznymi osoby samorealizującej się. Otóż osoba taka przejawia m.in.: akceptację samego siebie, innych ludzi oraz świata natury, postawę pokory i szacunku wobec ludzi i zjawisk, poczucie wspólnoty i głębokie relacje interpersonalne, posiadanie i kierowanie się wartościami moralnymi, względną niezależność od środowiska fizycznego i społecznego, odporność na wpływy kulturowe oraz równowagę między egoizmem a brakiem egoizmu ${ }^{60}$.

Innymi słowy, osoba dojrzała moralnie szanuje nie tylko ludzi i dba nie tylko o relacje z nimi. Nie jest konformistyczna, lecz kieruje się wyznawanymi wartościami. Czuje się częścią większej całości i działa ze względu na dobro wspólne, a nie wąsko pojęty interes własny. Wreszcie, dba o proporcjonalny rozwój wszystkich wymiarów swego człowieczeństwa: cielesnego, psychiczno-emocjonalnego i duchowego, do czego niezbędna jest zdrowa relacja ze środowiskiem przyrodniczym. I tak koło się zamyka. Zdrowa przyroda warunkuje człowieczeństwo, to zaś - zdrową relację z przyrodą.

\section{Zakończenie}

Omówiony w prezentowanym artykule spór o antropocentryzm w etyce środowiskowej pokazuje zasadniczą rolę przyjmowanego systemu wartości dla relacji człowieka z przyrodą. Stanowi on rdzeń świadomości ekologicznej. Sama wiedza nie zmienia postępowania człowieka. Niezbędna jest odpowiednio silna motywacja. Ta zaś swe źródła czerpie z doświadczenia życiowego, poczucia wartości, odpowiedzialności, piękna, sprawiedliwości, z wrażliwości, empatyczności, wiedzy i zdolności przewidywania. Motywacja wypływa z całej osoby ludzkiej. Całej osoby powinna więc dotyczyć edukacja i wychowanie do środowiska.

60 Por. A. Maslow, Motywacja i osobowość, tłum. J. Radzicki, Wydawnictwo Naukowe PWN, Warszawa 2006, s. 210-234. 
$\$$ 


\section{Ks. Ruseard F. Sadowski SDB}

ur. 30 V 1965 r., salezjanin, doktor habilitowany z zakresu filozofii, absolwent Wydziału Filozofii Chrześcijańskiej UKSW w Warszawie. Członek

Zespołu Redakcyjnego czasopisma „Seminare. Poszukiwania naukowe”. Inicjator powołania do życia Towarzystwa Naukowego Franciszka Salezego, sekretarz jego zarządu w czasie kadencji 2007-2011 i 2012-2017 oraz członek kilku międzynarodowych towarzystw naukowych. W latach 2008-2012 członek Senatu UKSW, a w latach 2010-2013 rektor Wyższego Seminarium Duchownego Towarzystwa Salezjańskiego w Lądzie. Autor wielu artykułów naukowych, redaktor kilku pozycji książkowych w języku polskim $i$ angielskim, uczestnik wie-

lu międzynarodowych i krajowych konferencji naukowych. W roku 2004 doktoryzował się na podstawie pracy Stanowisko Hansa Jonasa wobec problemu psychofizycznego, a w roku 2015 uzyskał stopien doktora habilitowanego na podstawie monografii Filozoficzny spór o rolę chrześcijaństwa w kwestii ekologicznej.

Od roku 2005 pracownik Instytutu Ekologii i Bioetyki UKSW. Jego zainteresowania filozoficzne skupiają się wokół zagadnień związanych $\mathrm{z}$ antropologią środowiskową, a szczególnie ekologią kulturową Juliana Haynesa Stewarda, filozofią środowiskową, humanistyczną refleksją nad kryzysem ekologicznym oraz rolą religii w tzw. kwestii ekologicznej. 


\section{Ks. Ryszard Sadowski SDB \\ UKSW w Warszawie \\ Ekofilozoficzne elementy chrześcijańskiej promocji życia}

Wprowadzenie

Ekofilozofia lub filozofia środowiskowa, to dyscyplina filozoficzna, która podejmuje badania na temat środowiska naturalnego oraz miejsca człowieka w tym środowisku i jego relacji do pozaludzkich form życia ${ }^{1}$. Wśród głównych zagadnień podejmowanych przez tę stosunkowo młodą dyscyplinę filozoficzną jest poszukiwanie odpowiedzi na pytanie o wartość przyrody pozaludzkiej, sposób podejścia do współczesnych wyzwań ekologicznych, a szczególnie do degradacji przyrody, szybkiego wymierania gatunków, zanieczyszczeń Ziemi, zmian klimatycznych, rosnącej populacji ludzkiej, konsumpcyjnego stylu życia itp.

Genezę filozofii środowiskowej powszechnie upatruje się w atmosferze lat 60. XX wieku przepojonej lękiem przed użyciem broni atomowej, zanieczyszczeniem środowiska, wyczerpaniem się zasobów naturalnych, powszechną chemizacją rolnictwa, ogólnie - zagrożeniem przetrwania ludzkości, a nawet życia jako takiego na Ziemi. Impulsem, który bezpośrednio przyczynił się do powstania filozofii środowiskowej, były publikacje, które znacząco wpłynęły na opinię publiczną Zachodu oraz środowiska uczonych i polityków. Do najważniejszych spośród nich należą: książka Rachel Carson pt. Silent Spring (1962), artykut Garretta Hardina The Tragedy of the Commons (1968), książka Paula Ehrlicha Population Bomb (1968) oraz tzw. pierwszy raport dla Klubu Rzymskiego pt. Granice wzrostu (1972)².

\footnotetext{
1 Por. A. Holland, Environmental Philosophy, w: The Cambridge Dictionary of Philosophy, red. R. Audi, Cambridge University Press, Cambridge - New York 1999, s. 268-269.

2 Por. A. Brennan, Environmental Philosophy. Contemporary Philosophy, w: Encyclopedia of Environmental Ethics and Philosophy, red. J. B. Callicott, R. Frodeman, t. 1, MacMillan Reference Library, Detroit 2009, s. 372.
} 
Ekofilozofia w sensie ścisłym pojawia się w latach 60. i 70. XX w. wraz z przebudzeniem ekologicznym oraz dostrzeżeniem konieczności poszerzenia debaty nad kryzysem ekologicznym ${ }^{3}$. Zagadnienia, które obecnie podejmuje ekofilozofia, były podejmowane już znacznie wcześniej przez różne szkoły filozoficzne na przestrzeni wieków. Można wręcz stwierdzić, że «zielona nić» istnieje w refleksji filozoficznej już od starożytności ${ }^{4}$.

Wiele wskazuje na to, że chrześcijaństwo i ekofilozofia mają ze sobą wiele wspólnego, w obu bowiem przypadkach chodzi, a przynajmniej powinno chodzić, o promocję życia, co wydaje się zaskakujące w konfrontacji z praktyką życia i licznymi atakami na chrześcijaństwo ze strony środowisk tzw. zielonych. Pomimo licznych przejawów niechęci do chrześcijaństwa ze strony ruchów ekologicznych i prób obwiniania go o spowodowanie współczesnego kryzysu ekologicznego, chrześcijanie i aktywiści ekologiczni na gruncie praktycznym, a chrześcijańscy intelektualiści i ekofilozofowie na gruncie teoretycznym - mogą i powinni wzajemnie się wspierać. W wielu bowiem zagadnieniach stanowiska obu stron są zbieżne.

\section{Chrześcijaństwo religią życia}

Życie jest centralnym zagadnieniem doktryny chrześcijańskiej, jej fundamentem jest bowiem prawda o zmartwychwstaniu, czyli pokonaniu śmierci i powrocie do życia. Cała historia zbawienia dotyczy powrotu człowieka do życia w pierwotnej harmonii z Bogiem i przyrodą. W Ewangelii Jezus wprost powiedział o sobie: „Ja jestem zmartwychwstaniem i życiem. Kto we Mnie wierzy, choćby i umarł, żyć będzie" (J 11,25)

Bóg nie tylko jest życiem, ale jest także źródłem życia. Stworzył On bowiem świat i podtrzymuje go w istnieniu. Objawiając Mojżeszowi swoje Imię, stwierdza: „JESTEM, KTÓRY JESTEM” (Wj 3,14). Nie wchodząc w złożoną analizę filozoficzną terminu «istnienie», za Andrzejem Maryniarczykiem można powiedzieć, że greckiemu ((to) éinai) (to on) lub łacińskiemu (esse, existere, existentia) w języku potocznym odpowiada: życie,

\footnotetext{
${ }^{3}$ Konrad Waloszczyk wymienia dwanaście czynników, które jego zdaniem przyczyniły się do powstania ekofilozofii. Por. K. Waloszczyk, Kryzys ekologiczny w świetle ekofilozofii, Wydawnictwo Politechniki Łódzkiej, Łódź 1996, s. 200-207.

4 Por. K. Waloszczyk, Planeta nie tylko ludzi, PIW, Warszawa 1997, s. 229-230.

5 Wszystkie teksty biblijne przytaczane w niniejszym opracowaniu pochodzą z Biblii Tysiąclecia online, Poznań 2003 (IV wyd.), <www.biblia.deon.pl>, (data dostępu: 17.08.2015).
} 
w przeciwieństwie do śmierci; to, co rzeczywiste w odróżnieniu od czegoś, co pozorne; to, co jest, w odróżnieniu od tego, czego nie $\mathrm{ma}^{6}$.

Chrześcijański Bóg nie tylko stworzył świat i podtrzymuje go w istnieniu, On także troszczy się o niego, w sposób szczególny o obecne w nim życie. „Oszczędzasz wszystko, bo to wszystko Twoje, Panie, miłośniku życia!" (Mdr 11,26). Bóg Biblii wielokrotnie okazuje troskę o wszelkie formy życia. Dobrze ilustruje to komentarz amerykańskiego ekofilozofa Billa McKibbena do Księgi Hioba, w którym stwierdza, że wymowa tej księgi wyraźnie wskazuje, że człowiek nie stanowi centrum wszechświata, a Bóg odczuwa radość, troszcząc się o całą przyrodę, której tajemnic człowiek nie jest w stanie w pełni ogarnąć (por. Hi 38) ${ }^{7}$.

Chrześcijaństwo od swych początków promuje prośrodowiskowe postawy swych wyznawców. Przyroda i wszystkie formy życia już w Księdze Rodzaju zostały uznane za dobre. Stwierdzenie ,jest dobre” na określenie kolejnych dzieł Boga pojawia się w pierwszym opisie stworzenia wielokrotnie, a w jego zakończeniu Bóg stwierdza, że „wszystko, co uczynił, było bardzo dobre” (Rdz 1,31). Drugi opis stworzenia ukazuje judeochrześcijańskie pojmowanie relacji człowieka do przyrody. Polskie tłumaczenie kluczowego fragmentu brzmi: „Pan Bóg wziął zatem człowieka i umieścił go w ogrodzie Eden, aby uprawiał go i doglądał" [podkreślenie - RS] (Rdz 2,15). Użyty w polskim tłumaczeniu termin «uprawiać» to hebrajski czasownik äbad, którego podstawowe znaczenie to «służyć». W Biblii czasownik ten wyraża służbę niewolnika względem jego właściciela (por. Rdz 12,6) lub narodu podbitego względem zwycięskiego (por. Wj 5,9). W pełni uprawniona wydaje się więc interpretacja, że zadanie człowieka nie polega na uprawianiu Edenu, jak sugeruje to polskie tłumaczenie, lecz raczej na służeniu mu. Zaś polskiemu czasownikowi «doglądać» W oryginale hebrajskim odpowiada czasownik šamar, który posiada wiele znaczeń, m.in. strzec, chronić, pilnować, troszczyć się, zachować $^{8}$. Analiza lingwistyczna tego fragmentu pozwala więc stwierdzić, że w relacji człowiek-przyroda, człowiek służy przyrodzie i ma wobec niej obowiązek troski ${ }^{9}$.

${ }^{6}$ Por. A. Maryniarczyk, Istnienie, w: Powszechna Encyklopedia Filozofii, red. A. Maryniarczyk, t. 5, Polskie Towarzystwo Tomasa z Akwinu, Lublin 2004, s. 44-85.

7 Por. B. McKibben, The End of Nature, Random House, New York 1989, s. 76.

8 Por. Wielki słownik hebrajsko-polski i aramejsko-polski Starego Testamentu, red. L. Koehler, W. Baumartner, J. J. Stamm, Oficyna Wydawnicza „Vocatio”, Warszawa 2008, t. 2, s. 546-549; por. także L. Greenspoon, From Dominion to Stewardship? The Ecology of Biblical Translation, "Journal of Religion \& Society” (2008)3, s. 165.

9 Por. C. Pardee, Making Earth Heaven: Ecological Implications of Genesis 1-3, "Leaven" 21(2013)3, s. 127. 
Wprawdzie Biblia nie pozostawia wątpliwości, że człowiek jest stworzeniem wyjątkowym i otrzymał w stosunku do pozostałych stworzeń mandat zwierzchnictwa. Nie oznacza to jednak, że człowiek jest absolutnym panem stworzenia. Nie wolno mu dysponować światem w niczym nieskrępowany sposób $^{10}$. Bóg jest bowiem Stwórcą i Panem świata, człowiek zaś działa jedynie z Jego upoważnienia i w ramach kompetencji, jakich mu Bóg udzielił. Co więcej, Bóg uczynił człowieka strażnikiem i opiekunem stworzenia ${ }^{11}$. Wbrew stereotypom, głoszącym, że Pismo Święte promuje nieskrępowaną dominację człowieka nad przyrodą, lingwistyczne badania pozwalają stwierdzić, że Biblia ukazuje człowieka nie jako pana ogrodu, lecz jako osobę służącą ogrodowi, od którego jest on zależny jak sługa od swego pana ${ }^{12}$.

Przekonanie, że Bóg troszczy się jedynie o człowieka jest stereotypem opartym na fragmencie Księgi Rodzaju: „Bądźcie płodni i rozmnażajcie się, abyście zaludnili ziemię i uczynili ją sobie poddaną; abyście panowali nad rybami morskimi, nad ptactwem powietrznym i nad wszystkimi zwierzętami pełzającymi po ziemi" (Rdz 1,28). Przekonanie to nie znajduje jednak potwierdzenia w Biblii, która w wielu miejscach mówi o trosce Boga o wszystkie istoty żywe i nakłada na człowieka ograniczenia w korzystaniu z przyrody. Przykładowo, ta sama księga Biblii wskazuje, że rośliny mają służyć za pokarm zarówno człowiekowi, jak i zwierzętom, ptakom i gadom ( $\mathrm{Rdz} 1,29-30)$. Po potopie zaś wszystkie pary ocalonych przez Noego zwierząt otrzymały polecenie bycia płodnymi i rozmnażania się (por. Rdz $8,17)$. Trudno zgodzić się także z tymi, którzy uważają, że Bóg troszczy się o życie pozaludzkie tylko ze względu na potrzeby człowieka. Bóg bowiem okazuje także troskę o dzikie zwierzęta (por. Hi 39,5) i trawę w miejscu, gdzie człowiek z niej nie korzysta (por. Hi 38,26-27). Na potwierdzenie tej tezy brytyjski filozof Robin Attfield przywołuje Psalm 104 jako wyjątkowy przykład troski Boga o całe stworzenie, którego człowiek jest tylko częściąa ${ }^{13}$.

10 Por. J. B. Callicott, Genesis Revisited: Murian Musings on the Lynn White, Jr. Debate, „Environmental History Review” 14(1989)1-2, s. 70-71; por. także R. Attfield, The Ethics of Environmental Concern, Athens- University of Georgia Press, London 1991, s. 26-28.

11 Por. R. F. Sadowski, Filozoficzny spór o rolę chrześcijaństwa w kwestii ekologicznej, TNFS, Warszawa: 2015, s. 94-95.

12 Por. T. Hiebert, The Human Vocation: Origins and Transformations in Christian Traditions, w: Christianity and Ecology, red. D. T. Hessel, R. R. Ruether, Harvard University Press, Cambridge 2000, s. 140; por. także N. Wirzba, The Paradise of God. Renewing Religion in an Ecological Age, Oxford University Press, Oxford - New York 2003, s. 136-145.

13 Por. R. Attfield, The Ethics of Environmental Concern, dz. cyt., s. 26. 
Bóg Biblii jest więc Życiem, które powołało do istnienia życie, podtrzymuje go w istnieniu i troszczy się o nie. Bóg powołał też człowieka do współpracy w trosce o życie i wprowadził nakaz poszanowania życia w każdej jego formie, zaś życia ludzkiego w sposób szczególny, chroniąc je kategorycznym zakazem zabijania (por. Wj 20,13).

\section{Przyroda jako przestrzeń poznawania Boga}

Fundamentem chrześcijańskiego podejścia do przyrody jest przekonanie, że w stworzeniu człowiek odkrywa prawdę o Stwórcy, nie tylko Jego istnienie, ale także Jego przymioty. Starożytni pisarze chrześcijańscy mówią nawet, że Bóg napisał dla człowieka dwie księgi: Księgę Pisma Świętego i Księgę Przyrody. Pierwszą napisał przy pomocy liter, drugą zaś przy pomocy stworzeń ${ }^{14}$. Ważnym elementem chrześcijańskiej doktryny jest przekonanie, że Bóg dokonał aktu stworzenia wg określonego porządku i ustanowił prawa, które rządzą funkcjonowaniem świata ${ }^{15}$. Wyraźnie mówią o tym biblijne fragmenty: „Aleś Ty wszystko urządził według miary i liczby, i wagi!” (Mdr 11,20) oraz „Chwalcie Go, słońce i księżycu, [...] On bowiem nakazał i zostały stworzone, utwierdził je na zawsze, na wieki; nadał im prawo, które nie przeminie" (Ps 148,3-6).

O możliwości poznawania Stwórcy w Jego dziełach mówi już wczesnochrześcijańska literatura, w której obecna jest zaczerpnięta z Biblii metafora «księgi natury» (por. Iz 34,4; Ap 6,14). Zgodnie z nią, Bóg objawia się człowiekowi m.in. w przyrodzie. Pierwszym chrześcijańskim pisarzem, który porównał przyrodę do księgi mówiącej o Bogu był św. Antoni Wielki $(251-356)^{16}$, któremu przypisuje się zdanie „Moją księgą jest stworzona przyroda, która jest zawsze wokół mnie, kiedykolwiek chcę czytać słowa Boga"17. Do metafory «księgi przyrody» nawiązywali także Bazyli Wielki,

${ }_{14}$ Por. C. J. Glancken, Traces on the Rhodian Shore. Nature and culture in western thought from ancient times to the end of the eighteenth century, University of California Press, Berkeley 1976, s. 203.

15 Por. T. E. Huff, The Open Society, Metaphysical Beliefs, and Platonic Sources of Reason and Rationality, w: Karl Popper, a Centenary Assessment. Metaphysics and Epistemology, red. I. Jarvie, K. Milford, D. Miller, Ashgate Publishing 2006, s. 34-35.

16 Por. T. W. Mann, God of Dirt: Mary Oliver and the Other Book of God, Cowley Publications, Cambridge 2004, s. xiii.

17 Sokrates Scholastyk, Historia Kościoła, tłum. S. J. Kazikowski, Instytut Wydawniczy PAX, Warszawa 1986, księga IV, rozdz. 23, s. 362-363. 
Grzegorz z Nyssy, Augustyn z Hippony, Jan Kasjan, Jan Chryzostom, Efrem ze Smyrny i Maksym Wyznawca. Inni zaś pisarze wczesnochrześcijańscy, choć nie odnosili się wprost do tej metafory, to jednak w swych pismach mówili o tym, że Bóg objawia się w swych dziełach ${ }^{18}$.

Jednym $\mathrm{z}$ bardziej znanych w tym względzie fragmentów chrześcijańskiego dziedzictwa jest homilia św. Bazylego Wielkiego (329-379), która zainspirowała wielu późniejszych pisarzy mówiących o przyrodzie jako przestrzeni poznania Stwórcy: „Kontemplując piękno stworzeń, możemy dzięki nim, jak gdyby były literami i słowami, odczytywać mądrość i opatrzność Boga w całym stworzeniu"19. Podobne ujęcie można znaleźć w pismach św. Augustyna: „Musisz słuchać boskiej stronicy; jest to księga wszechświata, który musisz obserwować. Stronice Pisma Świętego mogą być odczytane jedynie przez tych, którzy posiadają umiejętność czytania i pisania, podczas gdy każdy, nawet człowiek niewykształcony, może czytać księgę wszechświata”20. W jednej ze swoich homilii św. Augustyn mówi: „Niektórzy, aby poznać Boga, czytają księgi. Istnieje jednak wielka księga stworzenie. Spójrz poniżej i powyżej, obserwuj, czytaj. Bóg, którego chcesz odkryć, nie napisał liter atramentem; on postawił przed twymi oczami rzeczy, które stworzył. Czy możesz prosić o bardziej donośny głos niż ten?"21. Augustyn jednak rzadko mówi o «księdze przyrody» (magnus liber naturae rerum ${ }^{22}$, częściej zaś, pisząc o możliwości poznawania Boga w świecie, stosuje wyrażenie vestiga Dei (ślady, tropy), które Bóg pozostawił człowiekowi w przyrodzie ${ }^{23}$.

Pisarze chrześcijańscy, mówiąc o możliwości poznawania Boga w Jego dziełach, używali także metafory lustra (speculum), według której Stwórca odbija się w stworzeniu jak w lustrze. Poznając więc przyrodę,

18 Por. G. Tanzella-Nitti, The Two Books Prior to the Scientific Revolution, "Perspectives on Science \& Christian Faith" 57(2005)3 s. 237.

19 S. Basili Magni, Homilia De Gratianum Actione, nr 2 w: Patrologia Graeca, red. J-P. Migne, tom XXXI, Paris 1885, kol. 222c-223a.

20 Augustinus, Enarratio in Psalmum XLV, nr 7, w: Patrologia Latina, red. J.-P. Migne., tom XXXVI, Paris 1845, kol. 518.

${ }^{21}$ Cyt. za: G. Tanzella-Nitti, The Two Books Prior to the Scientific Revolution, art. cyt., s. 237.

22 Augustinus, Contra Faustum Manichaeum, księga XXX, rozdz. XX, w: Patrologia Latina, red. J-P. Migne, tom XLII, Paris 1845, kol. 509.

${ }^{23}$ Por. S. Augustinus, Ennarratio in Psalmus XXXIII, I, 4, w: Patrologia Latina, tom XXXVI, dz. cyt., kol. 302. 
można poznać jej Stwórcę ${ }^{24}$. Dobrze wyraża to myśl Maksyma Wyznawcy (580-662): „Nie znamy istoty Boga. Znamy Go raczej z dostojeństwa stworzenia i z Jego opatrznościowej opieki nad wszystkimi stworzeniami. Dzięki temu, jak w lustrze, możemy pojąć Jego nieskończoną dobroć, mądrość i potęgę"25. Orygenes (185-254) zaś stwierdza, że stworzenie i Biblia tak sobie odpowiadają, że osoba szukająca odpowiedzi na pytania w Biblii i osoba szukająca odpowiedzi na te same pytania w przyrodzie, dojdą do tych samych wniosków ${ }^{26}$. Niemal tysiąc lat później Tomasz z Akwinu (1224-1274), mówiąc o poznawaniu przyrody, stwierdzi, że błędy w poznaniu stworzeń wpływają na błędy w poznaniu Boga ${ }^{27}$.

\section{Wybrane modele chrześcijańskiego ujmowania przyrody}

W świadomości społecznej pozytywne chrześcijańskie nastawienie do przyrody najczęściej ogranicza się do osoby św. Franciszka z Asyżu. Wielu uważa, że jego ukochanie przyrody jest wyjątkiem wobec powszechnie obowiązującego stereotypu o negatywnej roli chrześcijaństwa w kwestii ekologicznej. W znacznej mierze przyczynił się do tego wielokrotnie przedrukowywany artykuł Lynna White'a pt. The Historical Roots of Our Ecologic Crisis ${ }^{28}$. Wywołana nim debata pozwoliła na przeprowadzenie dogłębnej analizy roli chrześcijaństwa w sprawstwie i przeciwdziałaniu kryzysowi ekologicznemu ${ }^{29}$. Zaś przedstawienie przez papieża Franciszka encykliki Laudato Si' znacząco wpłynęło na ukazanie, że troska o stworzenie jestnieodłącznym elementem tradycji chrześcijańskiej. Troska ta jest obecna w nauczaniu Kościoła od pierwszych wieków jego istnienia. Dobrymi ilustracjami przyjaznej relacji chrześcijan do przyrody są wybrane modele ujmowania przyrody przez różnych przedstawicieli tradycji chrześcijańskiej. Do najbardziej

${ }^{24}$ Por. O. Pedersen, Księga Natury, „Zagadnienia Filozoficzne w Nauce” XIV(1992), s. $22-23$.

25 The Philokalia, red. G.E.H. Palmer et al., tom 2, Faber and Faber, London 2010, s. 82.

${ }^{26}$ Por. Origenis, Commentaris in Psalmum Primum, w: Patrologia Graeca, red. J-P. Migne, tom XII, Paris 1862, kol. 1079-1082.

${ }_{27}$ Por. Tomasz z Akwinu, Summa contra gentiles. Prawda wiary chrześcijańskiej w dyskusji z poganami innowiercami i błądzącymi, tłum. Z. Włodek, Wł. Zega, W drodze, Poznań 2003, tom 1, księga 2, rozdz. 3, s. 263.

28 Por. J. Passmore, Man's Responsibility for Nature. Ecological Problems and Western Traditions, Scribner, New York 1974, s. 5; por. także E. Whitney, Lynn White, Ecotheology, and History, „Environmental Ethics” 15(1993)2, 157-158.

29 Por. R. F. Sadowski, Filozoficzny spór o rolę chrześcijaństwa w kwestii ekologicznej, TNFS, Warszawa 2015. 
reprezentatywnych w tym względzie należa: 1) Duchowy model ujmowania przyrody w chrześcijaństwie celtyckim; 2) Oblubieńczy model ujmowania przyrody w pismach Hildegardy z Bingen; 3) Braterski model ujmowania przyrody w tradycji franciszkańskiej oraz 4) Opiekuńczy model ujmowania przyrody w tradycji benedyktyńskiej.

\subsection{Duchowy model ujmowania przyrody w chrześcijaństwie celtyckim}

Chrześcijaństwo celtyckie charakteryzuje się wyjątkowym ujmowaniem miejsca i roli przyrody w życiu człowieka. Powszechnie uważa się, że silny związek Celtów z przyrodą jest konsekwencją wyjątkowego piękna przyrody, w której przyszło im żyć. W pięknie otaczającego ich krajobrazu dostrzegali obecność elementów duchowych, a szczególnym miejscom przypisywali wyjątkowe właściwości, dzięki którym człowiek może doświadczać spotkania z Bogiem. Celtowie zarówno w okresie przedchrześcijańskim, jak i w okresie chrześcijańskim dostrzegali w przyrodzie nie tylko chwałę Stwórcy, ale także uważali, że posada ona swoją własną władzę, obecność, tajemniczość i swój własny głos. Dla Celtów krajobraz był zarówno wyraźny - przepełniony światłem, jak i tajemniczy - obfitujący w święte misteria. W okresie przedchrześcijańskim wierzyli oni, że przyrodę zamieszkują liczni bogowie i boginie. Po przyjęciu chrześcijaństwa zachowano ten duchowy element obecny w przyrodzie, przypisując wyjątkowym miejscom obecność Boga, aniołów i świętych ${ }^{30}$.

W przedchrześcijańskiej strukturze plemiennej Celtów szczególną rolę pełnili druidzi, których uważano za „jasnowidzów posiadających ogromną wiedzę, którym bliskość z przyrodą umożliwiała wędrowanie pomiędzy światami ludzkimi i światami niewidzialnymi" ${ }^{31}$. Chrześcijańscy ewangelizatorzy, którzy pojawili się w agrarnej kulturze celtyckiej, stopniowo zaczęli przejmować funkcję druidów. Silna więź druidów z przyrodą wywarła wpływ na ukształtowanie się podobnej więzi wśród chrześcijańskich mnichów, którzy na swe pustelnie i klasztory często wybierali miejsca wyjątkowe pod względem przyrodniczym, wykorzystywane wcześniej przez druidów ${ }^{32}$.

Celtycka duchowość chrześcijańska jest unikalną syntezą starożytnego pogaństwa i wiary chrześcijańskiej. Do najbardziej charakterystycznych

30 Por. E. C. Sellner, The Celtic Soul Friend, Ave Maria Press, Notre Dame 2002, s. 119-121.

31 C. Matthews, Celtic Tradition, Element Books, Shaftesbury 1995, s. 40.

32 Por. C. Avens, R. Zelley, Walking the Path of ChristoSophia. Exploring the Hidden Tradition in Christian Spirituality, AuthorHouse, Bloomington 2005, s. 157-162. 

ści i grzechu ${ }^{33}$. Wizja świata obecna w chrześcijańskiej tradycji celtyckiej była wyjątkowa na gruncie chrześcijańskim, miała bowiem charakter holistyczny i unikała podkreślania dualistycznego podziału rzeczywistości na świat fizyczny i duchowy. Pozwalało to adoptować przedchrześcijańską więź z przyrodą do chrześcijańskiego nauczania celtyckich mnichów oraz włączyć mityczne dziedzictwo pogańskie do tradycji chrześcijańskiej. Pierwsi chrześcijańscy Celtowie wierzyli w magię czerpiącą swą siłę z witalności przyrody oraz ścisłych więzi człowieka z przyrodą. Chrystusa postrzegali jako archetypicznego druida lub «Pana Żywiołów», który był ucieleśnieniem przyrody ${ }^{34}$. Tak ujmowana celtycka duchowość chrześcijańska tłumaczy popularność ruchu monastycznego, który stanowił fundament chrześcijaństwa celtyckiego. „Historia Kościoła celtyckiego, to zasadniczo historia mnichów i klasztorów”35.

O ważności przyrody dla Celtów oraz o miejscu przyrody w nauczaniu celtyckich misjonarzy ewangelizujących swych współplemieńców niech świadczy fakt, że córki jednego z irlandzkich królów przyjęły chrześcijaństwo po spotkaniu ze św. Patrykiem, który na ich pytanie o Boga chrześcijan odpowiedział: „Nasz Bóg jest Bogiem wszystkiego, Bogiem nieba i ziemi i morza i rzeki, Bogiem słońca i księżyca i wszystkich gwiazd, Bogiem wysokich gór i rozległych dolin; Bogiem nad niebem i w niebie i pod niebem. Przebywa zarówno w niebie, jak i na ziemi, a także w morzu i we wszystkim, co w nim jest. Bóg pobudza wszystkie istoty, daje życie wszystkim stworzeniom, przewyższa wszystko. Nasz Bóg rozpala światło słońca i światło księżyca. Uczynił źródła na wyschłej ziemi i suche wyspy na morzu, gwiazdy wyznaczył, by służyły słońcu i księżycowi. Bóg ma współ-odwiecznego ze sobą Syna, który jest bardzo podobny do Ojca. Syn nie jest jednak młodszy od Ojca, ani Ojciec nie jest starszy od Syna. A Duch Święty tchnie w Nich. Ojciec i Syn i Duch Święty nie są rozdzielni. Pragnę połączyć was z Synem Niebieskiego Króla, ponieważ jesteście córkami ziemskiego króla"36.

${ }_{33}$ Por. E. C. Sellner, The Celtic Soul Friend, dz. cyt., s. 118.

34 Por. C. Avens, R. Zelley, Walking the Path of ChristoSophia, dz. cyt., s. 161-163.

${ }^{35}$ E. C. Sellner, The Celtic Soul Friend, dz. cyt., s. 116.

36 Cyt. za tamże, s. 122. 
Wyraźne odniesienia do przyrody znajdują się u największych celtyckich świętych. Celtycka „święta trójca”: św. Patryk (385-461), św. Brygida z Kildare (452-524) i św. Kolumban z Iony (521-597) w swych wypowiedziach wielokrotnie podkreślają rolę przyrody w odkrywaniu Boga. Nie stanowią w tym względzie wyjątku na tle celtyckiego chrześcijaństwa ${ }^{37}$. Jednym z najbardziej znanych utworów celtyckiego dziedzictwa Kościoła, w którym mocno osadzone są elementy przyrody jest Lorica (zbroja). Jest to modlitwa przypisywana św. Patrykowi, w której, aby zapewnić sobie ochronę, prosi on Boga o opiekę, przywołując moce niebieskie i ziemskie:

Zakładam dziś na siebie

potężną moc Trójcy Świętej,

moc wiary w Troistość,

i moc świadectwa o Jedności

Stworzyciela wszystkich stworzeń.

(...)

Zakładam dziś na siebie

moc Niebios,

światłość słońca,

blask księżyca,

splendor ognia,

bystrość błyskawicy,

chyżość wiatru,

głębokość morza,

stabilność ziemi,

wytrzymałość skały ${ }^{38}$.

Celtyccy mnisi budowali swe klasztory w ustronnych, malowniczo położonych, odludnych miejscach. Obcowanie z przyrodą miało wyraźnie formacyjny charakter, pozwalało im doświadczać zarówno piękna, jak i grozy przyrody oraz zakorzenienia ludzkiego życia w świecie fizycznym ${ }^{39}$.

37 Por. tamże, s. 123.

38 T. Cowan, Yearning for the Wind: Celtic Reflections on Nature and the Soul, New World Library, Novato 2003, s. 137.

39 Por. C. Avens, R. Zelley, Walking the Path of ChristoSophia, dz. cyt., s. 164. 
Potwierdzeniem harmonijnej koegzystencji celtyckich mnichów z przyrodą są liczne legendy mówiące o tym, że harmonia człowieka z Bogiem przybliża człowieka do świata przyrody. Jedną z takich legend jest opowiadanie o kosie i św. Kewinie, opacie z Glendalough (498-618). Gdy pewnego dnia św. Kewin udał się na modlitwę i w ekstazie przez wiele godzin miał wzniesione ku niebu ręce, w jego dłoni, jak w gnieździe, usiadł kos, uwił gniazdo i złożył jaja. Zgodnie z legendą, w trosce o pisklęta, św. Kewin tak długo trzymał wyciągnięte ręce, póki pisklęta w pełni nie opierzyły się i nie odleciały ${ }^{40}$.

Tradycja celtyckiego chrześcijaństwa obfituje w podania, które mówią o przyjaźni świętych ze zwierzętami, które ich wspomagały. Według legendy, św. Finianowi, założycielowi opactwa w Clonard, pomagały jelenie, które nosiły mu książki i ciągnęły wóz z drzewem na opał. Inne podanie mówi zaś o św. Molaisse z Devenish, który postanowił napisać książkę, lecz nie posiadał pióra. Problem ten rozwiązał ptak, upuszczając pióro, by święty mógł nim zapisywać swe myśli. Św. Ciaren z Saigir miał pomocnika w postaci dzika, który kłami pomagał mu wykopać w ziemi pustelnię. Zaś św. Cuthbert, po całonocnej modlitwie w lodowatej wodzie, został ogrzany przez dwie wydry. Legenda głosi, że ptaki i wiewiórki często nawiedzały św. Kolumbana z Kilmacdaugh, a mysz budziła go na modlitwę. O bliskiej więzi celtyckich mnichów z przyrodą świadczy lokalizacja ich pustelni i klasztorów lokowanych w miejscach wyjątkowo urokliwych, gdzie piękno przyrody symbolizowało ogród Eden i przypominało o pierwotnej harmonii człowieka z Bogiem i całym światem ${ }^{41}$.

Przykładem celtyckiej nie-dualistycznej wizji świata jest klasztor św. Kewina w Glendalough, położony w dolinie między dwoma jeziorami. Pielgrzymi, idąc wzdłuż rozległej doliny, dostrzegają najpierw klasztor, który wydaje się wyrastać z jej podnóża, cztery kanciaste kościoły z ich stromymi kamiennymi dachami bardzo przypominają skały okalające dolinę. Jedyną budowlą, która zakłóca harmonię krajobrazu, jest strzelista okrągła wieża zbudowana z kamienia, która swym kształtem wydaje się wskazywać niebo i kierunek do położonego powyżej jeziora. Mnisi nie zbudowali swego klasztoru nad brzegiem jeziora, ale na podmokłym terenie pomiędzy jeziorami.

\footnotetext{
40 Por. S. P. Bratton, Environmental Values in Christian Art, State University of New York Press, Albany 2008, s. 62.

${ }^{41}$ Por. J. Nash, Loving Nature. Ecological Integrity and Christian Responsibility, Abingdon Press, Nashville 1991, s. 83-84.
} 
Prawdopodobną przyczyną oddalenia klasztoru od jezior było jeszcze przedchrześcijańskie przekonanie, że jeziora te były miejscami uświęconymi.

W życiu klasztornym w Glendalough funkcjonowały dwa zasadnicze miejsca praktyk religijnych: zabudowania klasztorne z kościołami i przyległym do nich cmentarzem oraz wyżej położone jezioro, które było ulubionym miejscem kontemplacji mnichów szukających kontaktu z Bogiem. Mnisi często, za przykładem św. Kewina, modlili się, zanurzając się w toni jeziora lub wspinali się na urwiste zbocza doliny. Szukali tam odosobnienia na łonie przyrody, w której pragnęli odnaleźć obecność Boga i duchową siłę. Upatrywali ją bowiem nie w oderwaniu od przyrody, ale właśnie w łączności z nią ${ }^{42}$.

Wyżej położone jezioro jest niewidoczne z poziomu klasztoru Glendalough ani klasztor nie jest widoczny znad brzegu jeziora. Dualizminapięcie pomiędzy władzą człowieka i siłami przyrody, tak wyraźnie zaznaczający się w antycznej kulturze Grecji, w Glendalough jest nieobecny. Dla Celtów granice pomiędzy światem przyrodzonym i nadprzyrodzonym oraz pomiędzy człowiekiem i przyrodą były bez znaczenia. O ile helleńska koncepcja świata odnajdywała swą harmonię w dualizmie, o tyle celtycka koncepcja świata przepełniona była niezliczonymi stopniami i odcieniami dzielącymi oba światy ${ }^{43}$. Stąd propozycja, by celtyckie ujęcie świata, w którym rzeczywistość przyrodzona i nadprzyrodzona przenikają się i łączą, nazwać «duchowym» modelem ujmowania przyrody.

\subsection{Oblubieńczy model ujmowania przyrody w pismach Hildegardy z Bingen}

Dobrą ilustracją przyjaznego przyrodzie modelu relacji człowieka do świata jest twórczość św. Hildegardy z Bingen (1098-1179). Ta wybitna postać późnego średniowiecza była przeoryszą i fundatorką benedyktyńskich klasztorów żeńskich, zielarką, lekarką, wizjonerką, kompozytorką, głosicielką doktryny chrześcijańskiej oraz autorką licznych pism ${ }^{44}$.

Specyfika ujęcia przyrody przez Hildegardę z Bingen polega na dostrzeganiu obecności Stwórcy w całym stworzeniu. W jednej ze swych wizji wkłada w usta boskiej Mądrości następujące słowa: „Jestem płonącym życiem istoty Boga: rozpalam piękno pól; błyszczę w wodach; płonę w słońcu,

42 Por. S. P. Bratton, Environmental Values in Christian Art, dz. cyt., s. 63.

43 Por. tamże.

44 Por. C. Avens, R. Zelley, Walking the Path of ChristoSophia, dz. cyt., s. 129. 
księżycu i gwiazdach. A łagodnym wiatrem wspomagam witalność wszystkich stworzeń poprzez niewidzialne, wszystko podtrzymujące życie"45.

Hildegarda prezentuje nowatorski model świata, w którym wskazuje na sakralną relację między światem przyrodzonym i nadprzyrodzonym. Jej zdaniem świat nadprzyrodzony jest źródłem płodności przyrody. Hildegarda dostrzega boskość w zieloności ziemi i mówi o Bogu zasypującym pocałunkami ziemię. Jej zdaniem pocałunki te niosą w sobie życie. Stąd Thomas Berry proponuje jej koncepcję świata nazwać «modelem oblubieńczym», w myśl którego Ojciec Niebieski zaślubia Matkę Ziemię ${ }^{46}$. Hildegarda stoi na stanowisku, że istnieje jedna rzeczywistość, stanowiąca określoną całość, stworzoną przez Boga na kształt sieci rozciągniętej w nieskończoność przestrzenną i czasową. Tak przedstawiane stworzenie zespolone jest więzami Bożej miłości i wraz z żywiołami świata znajduje się w sercu Boga. W ten sposób całe dzieło stworzenia nosi na sobie ślady pocałunków Boga-Stworzyciela i Boga-Miłośnika Życia ${ }^{47}$.

Hildegarda przedstawia interesującą koncepcję życiodajnej siły świata jako zieloności (viriditas). W jej ujęciu zieleń nie jest jednak kolorem, lecz stanem, sposobem istnienia. Według św. Hildegardy zielone jest serce Boga, zielona jest płodność człowieka i piękno kobiecości, zielona jest także zdrowa egzystencja człowieka. Jej zdaniem, siła zielonej miłości Boga najpełniej ujawniła się w Jezusie Chrystusie. Dlatego Matkę Chrystusa - Maryję Hildegarda nazywa Viridissima Virgo ${ }^{48}$. Dzięki takiemu ujęciu określenie viridissima nabiera nowego znaczenia: pierwotnie rozumiane jako najbardziej zielona, dla Hildegardy oznacza najbardziej życiodajna. Viridissima Virgo wyraża zatem najbardziej płodną dziewice, która dała życie samemu źródłu życia - Jezusowi Chrystusowi ${ }^{49}$.

Św. Hildegarda z Bingen jest przekonana, że człowiek może przywrócić zakłóconą przez siebie harmonię przyrody. Przez żal i pokutę jest on bowiem zdolny do odnowienia siły życia (viriditas) przyrody, dzięki której

45 Cyt za: tamże, s. 130.

46 Por. T. Berry, B. Didcoct, Choosing Our Roots. Traditional Christian attitudes offer both problems and promise for healing the earth, "IN CONTEXT. A Quarterly of Humane Sustainable Culture" 8(1984)4, s. 28.

47 Por. Z. Łepko, R. F. Sadowski, Ekofilozoficzne znaczenie przesłania Hildegardy z Bingen, Studia Ecologiae et Bioethicae 12(2014)2, s. 18.

48 Por. Hildegard of Bingen, De Sancta Maria, w: Hildegard of Bingen's Book of Divine Works with Letters and Songs, red. M. Fox, Bear \& Company, Santa Fe 1987, s. 376-378.

49 Por. Z. Łepko, R. F. Sadowski, Ekofilozoficzne znaczenie przesłania Hildegardy z Bingen, art. cyt., s. 19-20. 
wszystko się odradza. Destitutio, czyli upadek świata, przemienia się w restitutio, czyli w odnowę stworzenia, które w ten sposób powraca do constitutio, czyli do pierwotnego stanu harmonii stworzonej przez $\mathrm{Boga}^{50}$.

\subsection{Braterski model ujmowania przyrody w tradycji franciszkańskiej}

Sposób, w jaki św. Franciszek z Asyżu okazywał troskę o stworzenie, dobrze ilustruje wypowiedź Jana Pawła II zawarta w Liście Apostolskim Inter Sanctos z 29 listopada 1978 roku, w którym papież ogłosił go patronem ekologów: „Świętego Franciszka z Asyżu słusznie zalicza się między tych świętych i słynnych mężów, którzy odnosili się do przyrody jako cudownego daru udzielonego przez Boga rodzajowi ludzkiemu. Albowiem on głęboko odczuł w szczególny sposób wszystkie dzieła Stwórcy i natchniony Bożym duchem wyśpiewał ową najpiękniejszą «Pieśń stworzeń», przez które, szczególnie przez brata słońce, brata księżyc i siostry gwiazdy niebieskie, oddał należne uwielbienie, chwałę, cześć i wszelkie błogosławieństwo najwyższemu i dobremu Panu"51.

Franciszkański model ujmowania przyrody jest dobrze znany i powszechnie akceptowany nawet przez środowiska pozachrześcijańskie. Święty Franciszek odszedł bowiem od obrazu człowieka jako «korony stworzenia» (por. Rdz 1), a nawet biblijnej koncepcji ogrodnika troszczącego się o ogród Eden (por. Rdz 2) i stworzył nowy model relacji człowieka do przyrody. Dla św. Franciszka słońce, księżyc, ogień, woda i wiatr to «brat słońce», «siostra księżyc», «brat ogień», «siostra woda» i «brat wiatr» ${ }^{52}$. Zaproponowany przez św. Franciszka model relacji człowieka do przyrody ma charakter partnerski i demokratyczny, jest przepełniony nie tylko szacunkiem, ale także głęboką miłością. Stąd model ten określa się jako «braterski».

\subsection{Opiekuńczy model ujmowania przyrody w tradycji benedyktyńskiej}

Jednym z największych osiągnięć duchowości benedyktyńskiej było łączenie pracy intelektualnej z pracą fizyczną, szczególnie z uprawą ziemi. Sławna zasada ora et labora do dziś funkcjonuje w naszej kulturze.

\footnotetext{
50 Por. tamże, s. 22.

51 Jan Paweł II, List Apostolski „Inter Sanctos” (29 listopada 1979).

52 Por. św. Franciszek z Asyżu, Pieśń słoneczna, <www.swanna.pl/prw/pisma/pisma_fr/piesn_slon.html>, (data dostępu: 17.08.2015).
} 
Nigdy wcześniej w cywilizacji Zachodu nie było precedensu łączenia pracy intelektualnej z pracą fizyczną, którą wcześniej powierzano jedynie służbie. Benedyktyni wypracowali bardzo szczególny stosunek do przyrody, nie tylko uprawiając ziemię, ale także zdobywając wiedzę na ten temat i stosując ją na terenie swych gospodarstw oraz ucząc nowoczesnych metod uprawy ziemi. Ich opiekuńcza relacja do przyrody była konsekwencją obcowania na co dzień z przyrodą oraz zdobywania wiedzy na jej temat ${ }^{53}$. Stąd Thomas Berry zaproponował by model benedyktyńskiego ujmowania przyrody określić jako «opiekuńczy».

\section{Zakończenie}

Wiele wskazuje na to, że istnieje możliwość wzajemnego wspomagania się przez myśl chrześcijańską i refleksję ekofilozoficzną w kształtowaniu właściwych postaw troski o życie. Doktryna chrześcijańska ma wiele do zaoferowania w kształtowaniu postaw pro-środowiskowych, podobnie jak ekofilozoficzne myślenie może wesprzeć niektóre aspekty wychowania do postaw chrześcijańskich.

Chrześcijaństwo kształtuje świadomość świętości i dobra stworzenia oraz odpowiedzialność za Ziemię, którą Stwórca powierzył opiece człowieka. Chrześcijańska perspektywa pozwala też wyraźnie dostrzec, jak mówił o tym Benedykt XVI w Bundestagu, że „w naszych stosunkach z przyrodą jest coś, co nie gra; że materia nie jest tylko materiałem, który mamy obrabiać, ale że sama ziemia zawiera w sobie własną godność, a my winniśmy kierować się jej wskazaniami" ${ }^{54}$.

Ponadto chrześcijaństwo podkreśla moralny wymiar odniesień do przyrody, które - gdy są zaburzone - coraz częściej określamy mianem «grzechów ekologicznych» lub «grzechów przeciw rzeczywistości stworzonej» ${ }^{55}$. Coraz częściej też słyszymy z ust najważniejszych liderów chrześcijańskich o «świadomości ekologicznej», a nawet konieczności «nawrócenia

\footnotetext{
53 Por. T. Berry, B. Didcoct, Choosing Our Roots, art. cyt., s. 28.

${ }^{54}$ Benedykt XVI, Przemówienie w Bundestagu z dnia 22.09.2011 roku, <www.opoka.org.pl/ aktualnosci/news.php?id=39463\&s=opoka\#>, (data dostępu: 18.08.2015).

55 Por. Papież Franciszek, Encyklika „Laudato Si” (24 maja 2015), nr 8; por. także W. H. Becker, Ecological sin, „Theology Today” 49(1992)2, s 152-164.
} 
ekologicznego $»^{56}$. Wiele ekologicznych kampanii edukacyjnych w Polsce i na świecie wprost odnosi się do argumentacji religijnej. Przykładem najbardziej spektakularnych działań w tym względzie są międzynarodowe religijne inicjatywy ekologiczne WWJDrive i Operation Noah. Na polskim zaś gruncie dobrze ilustruje to edukacyjno-informacyjna kampania Ministerstwa Ochrony Środowiska Nie zaśmiecaj swojego sumienia (2010), która wprost odnosiła się do moralnego i religijnego wymiaru relacji człowieka do przyrody ${ }^{57}$.

Refleksja ekofilozoficzna i pobudzanie wrażliwości na ochronę przyrody może dostarczyć ważnych argumentów na rzecz chrześcijańskiej obrony życia. Powszechnie dostrzega się niezwykłe zaangażowanie, szczególnie młodego pokolenia, w ochronę unikalnych obszarów przyrodniczych oraz ginących gatunków flory i fauny. Wielu ludzi gotowych jest do niebywałych poświęceń, by chronić życie w najróżniejszych jego przejawach. Niestety, nierzadko ci sami ludzie, bez skrupułów opowiadają się przeciw życiu, akceptując aborcję i eutanazję. Wykazywanie niekonsekwencji tych postaw wydaje się być tą formą strategii chrześcijańskich ruchów pro-life, która wciąż czeka na większe zastosowanie.

Wiele wskazuje na to, że przy wzajemnym poszanowaniu wartości przyświecających wrażliwym ekologicznie chrześcijanom oraz ekologom niezwiązanym z tradycją chrześcijańską istnieje szerokie pole współpracy na rzecz ochrony przyrody. Wydaje się, że - przy zachowaniu własnej tożsamości i uwzględnieniu wzajemnych ograniczeń - wciąż możliwe jest przeprowadzenie wielu wspólnych działań na rzecz dobra wspólnego, którym jest troska o środowisko naszej planety i obecne w nim życie.

${ }^{56}$ Papież Franciszek, Encyklika “Laudato Si”, nr 216-221; por. także John Paul II, Message for the Celebration of the World Day of Peace (1 January 1990), nr 1, <http://w2.vatican.va/ content/john-paul-ii/en/messages/peace/documents/hf_jp-ii_mes_19891208_xxiii-worldday-for-peace.html>, (data dostępu: 20.08.2015).

57 Por. Ministerstwo Ochrony Środowiska, Nie zaśmiecaj swojego sumienia, <www.mos. gov.pl/artykul/7_aktualnosci/11193_nie_zasmiecaj_swojego_sumienia_nowa_kampania_ spoleczna_ms.html>, (data dostępu: 18.08.2015). 
$\$$ 


\section{Jan Piskurewick}

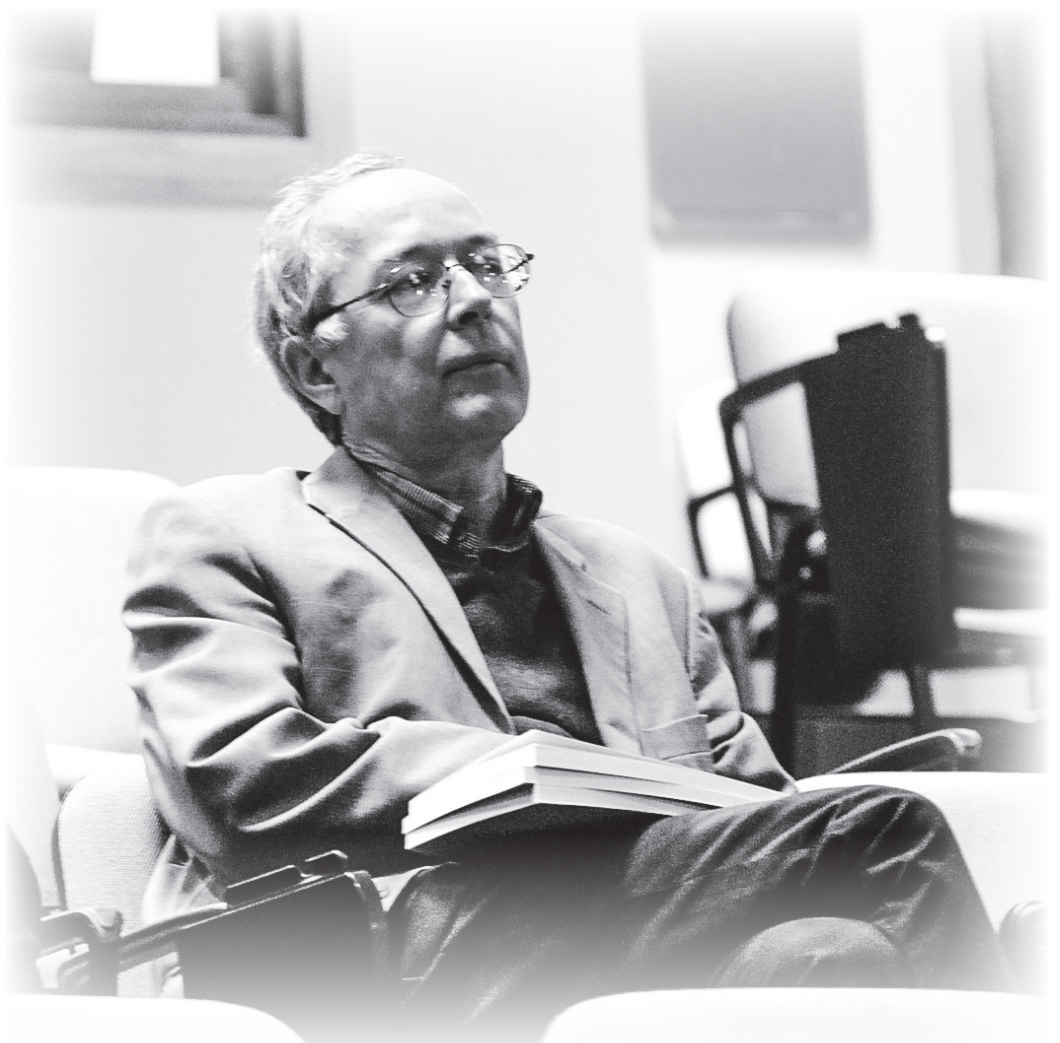

kierownik Katedry Historii Wychowania i Dziejów Oświaty na Wydziale Nauk Pedagogicznych UKSW. Ważniejsze publikacje: Warszawskie instytucje społecznego mecenatu nauki w latach 1869-1906, Wrocław 1990; W stużbie nauki i oświaty. Stanisław Michalski (1865-1949), Warszawa 1993; Prima inter pares. Polska Akademia Umiejętności w latach II Rzeczypospolitej, Kraków 1998; Między nauka a polityką. Maria SkłodowskaCurie w laboratorium i w Lidze Narodów, Lublin 2007. Zajmuje się szerokim spektrum zagadnień z zakresu historii nauki i oświaty, m.in. dziejami instytucji naukowych i oświatowych, postaciami wybitnych uczonych i pedagogów, związkami nauki i oświaty z dziejami społecznymi i politycznymi Polski i Europy. 


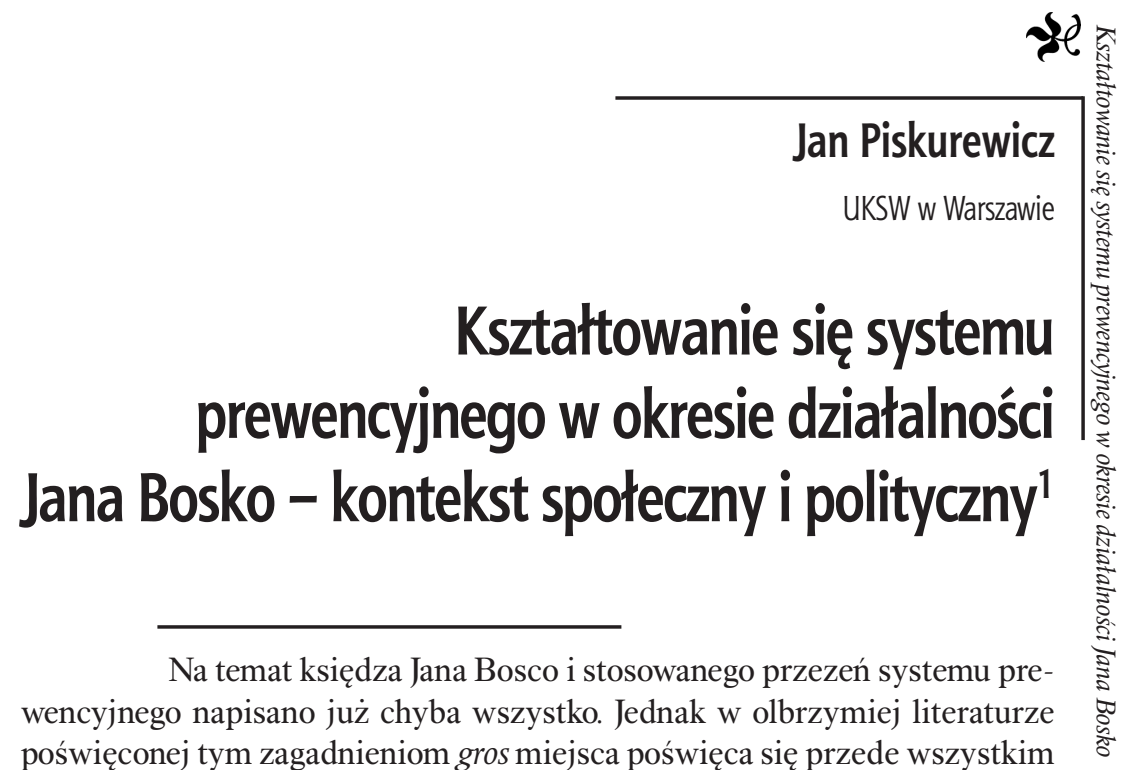
analizom pedagogicznym, w mniejszym stopniu uwzględniając realia społeczne i polityczne tamtego okresu i ich wpływ na taki, a nie inny kształt systemu prewencyjnego.

W moim referacie zamierzam wskazać na te właśnie, mniej uwzględniane, kwestie, które bezpośrednio wpłynęły na uformowanie systemu prewencyjnego w ujęciu ks. Bosco. Będę się przy tym opierał przede wszystkim na wypowiedziach samego Świętego, a także na wspomnieniach bezpośredniego świadka jego działalności - wychowanka i salezjanina Jana Bonettiego. Nada to mojemu referatowi bardziej źródłowy charakter.

Jak wiadomo, system prewencyjny nie jest oryginalną koncepcją stworzoną przez ks. Bosco i on sam był tego świadom. W poświęconej mu monografii Augustyn Auffray pisze, że gdy w 1886 r., a więc na dwa lata przed śmiercią, ks. Bosco otrzymał z jednego z seminariów duchownych list z prośbą o ujawnienie „klucza swego systemu wychowawczego”, stwierdził, że może nawet on sam go nie zna. Miał powiedzieć, że po prostu „zawsze szedł naprzód tak, jak Bóg go oświecał swą łaską i natchnieniem, stosownie do tego, czego wymagały okoliczności"2.

Nie znaczy to oczywiście, że ks. Bosco nie miał wiedzy o tego

\footnotetext{
${ }^{1}$ Artykuł w nieco zmienionej postaci ukazał się w „Forum Pedagogicznym” (2015)2.

${ }^{2}$ A. Auffray, Święty Jan Bosko, tłum. M. Gabryel, W. Nocoń, F. Socha, K. Szczerba, Wyd. Salezjańskie, Warszawa 2001, s. 168.
} 
rodzaju systemach prewencyjnych. Przebywając w turyńskim konwikcie przyjaźnił się z ks. Józefem Cafasso, który skierował jego uwagę na biedną i opuszczoną młodzież. Związany był ponadto $\mathrm{z}$ księdzem diecezji turyńskiej Janem Cocchi - pionierem odnowy oratorium. Wskazuje się na działalność żyjącego jeszcze w XVI w. św. Filipa Nereusza - twórcy oratorium jako ośrodka i metody wychowawczej, który stanowił bezpośrednią inspirację dla ks. Bosco w dziele tworzenia jego oratorium. $\mathrm{Z}$ analizy pism ks. Bosco wynika - zdaniem niektórych autorów - że, organizując życie oratoryjne, opierał się właśnie na regulaminach oratorium Filipa Nereusza, Konstytucjach i Regulaminach Towarzystwa Szkół Doktryny Chrześcijańskiej oraz poglądach i działalności takich postaci, jak św. Franciszek Salezy, św. Karol Boromeusz, św. Jan de la Salle, św. Wincenty á Paulo, a z jemu współczesnych wpływ nań mogli mieć: Ferrante Aporti, Jean Baptiste Blanchard i Aleksander Teppa ${ }^{3}$. Czy rzeczywiście mieli - prawdopodobnie nigdy się tego nie dowiemy.

Sama idea prewencji, jak pisze ks. prof. Kazimierz Misiaszek, była bardzo żywa w pierwszej połowie XIX w., a więc w czasie, kiedy kształtowała się świadomość i osobowość ks. Bosco. „Dostrzega się ją w wielu dziedzinach życia: politycznej, społecznej, ekonomicznej, religijnej i pedagogicznej [...] Czasem przyjmowała kształt cenzury różnych publikacji. Znajdowała sprzyjający grunt rozwoju w nowej rzeczywistości polityczno-społecznej, ukształtowanej w wyniku Świętego Przymierza, które odwołując się do religii, pragnęło przywrócić dawny ład. Najbardziej jednak dała o sobie znać w zakresie wychowania, w którym pogłębiona instrukcja uważana była za istotny element prewencji”"

W pierwszej połowie XIX wieku Turyn - stolica Piemontu i największe miasto tego regionu - przechodziło intensywny okres industrializacji. Napływały doń rzesze mieszkańców okolicznych wsi, uciekających przed panującą tam nędzą i głodem oraz z nadzieją znalezienia pracy dającej środki do życia. Ludność Turynu wzrastała w szybkim tempie (w latach 1808-1840 wzrosła dwukrotnie), ale równie szybko okazało się, że rozwijające się przemysł, handel i rzemiosło nie są jednak w stanie wchło-

\footnotetext{
3 J. Niewęgłowski, Wychowawczo-społeczna działalność salezjanów w Polsce w latach 1898-1989, Wyd. Towarzystwo Naukowe Franciszka Salezego, Warszawa 2011, s. 69-72.

4 K. Misiaszek, Główne idee systemu prewencyjnego św. Jana Bosko, w: Zastosowanie systemu prewencyjnego księdza Jana Bosko w placówkach opiekuńczo-wychowawczych, red. A. Fidelus, Częstochowa 2014, s. 10.
} 
nąć aż tak dużej liczby przybyszów. Zwiększała się liczba bezrobotnych, wśród których panować zaczęła bieda, głód i demoralizacja. Dotyczyło to zwłaszcza młodzieży, którą nikt się nie zajmował. Coraz więcej młodych ludzi wchodziło na drogę przestępstwa, która prowadziła ich często wprost do bram turyńskich więzień.

I to właśnie od posługi więźniom rozpoczął ks. Bosco swoje dzieło. We wspomnieniach pisał: „Wciąż miałem na myśli przede wszystkim tych, którzy wychodzili z więzienia. Namacalnie przekonałem się, że jeśli znajdą na wolności przyjaciela, który się nimi zajmie, będzie z nimi w świąteczne dni, znajdzie im pracę u uczciwego pracodawcy i odwiedzi ich w ciągu tygodnia, to zapomną o przeszłości i zaczną porządne życie. Staną się uczciwymi obywatelami i dobrymi chrześcijanami. Taki był początek naszego Oratorium, które dzięki Pańskiemu błogosławieństwu rozrosło się tak, jak bym się tego nigdy nie spodziewâ"

Oczywiście młodzi więźniowie zainteresowani byli przede wszystkim materialną pomocą, z czego ks. Bosco doskonale zdawał sobie sprawę i zawsze będzie brał to pod uwagę - także w odniesieniu do pozostałej młodzieży, nie tylko więźniów. Pisał: „Co sobotę wracałem do więzień z torbą pełną owoców, bułek i papierosów. Chciałem utrzymać kontakt z tymi młodymi nieszczęśnikami, którzy tam się znaleźli, pomóc im, pozyskać ich przyjaźn i zaprosić do Oratorium, gdy tylko opuszczą to smutne miejsce"6.

Początkowo celem ks. Bosco było przyjęcie tylko tych chłopców, którym groziła demoralizacja, a zwłaszcza tych, którzy wychodzili z więzienia. Szybko jednak doszedł do wniosku, że mogłoby wtedy powstać środowisko patologiczne, niesprzyjające odchodzeniu od złego. Wspominał: „By móc jednak utrzymać porządek i promieniować dobrocią, zapraszałem do Oratorium także innych chłopców, należycie wychowanych i dobrze się sprawujących. Pomagali mi oni w utrzymaniu porządku, czytaniu i wykonywaniu śpiewów liturgicznych. Od początku bowiem zauważyłem, że bez śpiewu i czytania interesujących książek nasze spotkanie byłoby jak ciało bez duszy"”.

Pierwsze trzy lata istnienia Oratorium (1841-1844), czynnego w dni świąteczne, były okresem ustalania się pewnych stałych punktów jego funkcjonowania, na które ks. Bosco kładł szczególny nacisk. Były nimi

\footnotetext{
5 J. Bosko, Wspomnienia Oratorium, Wyd. Salezjańskie, Warszawa 1987, s. 107.

6 Tamże, s. 110.

7 Tamże, s. 108.
} 
praktyki religijne. W swoich wspomnieniach pisał: „Spróbuję naszkicować obraz życia tego pierwszego Oratorium. Rano w dni świąteczne każdy mógł przystąpić do sakramentów spowiedzi i komunii, natomiast wszyscy starali się spełnić ten chrześcijański obowiązek przynajmniej raz w miesiącu. Wieczorami, o wyznaczonej godzinie, odbywały się lekcje katechizmu, poprzedzone jakąś pieśnią nabożną, a na zakończenie opowiadałem niecodzienną historię i rozdawałem drobiazgi wszystkim, albo też tylko niektórym, którzy mieli szczęście wygrać przez ciągnięcie losu"».

$\mathrm{Z}$ czasem skład uczestników Oratorium zaczął ulegać zmianie. „Większość chłopców - wspominał ks. Bosco - stanowili kamieniarze, murarze, sztukatorzy i brukarze pochodzący z odległych wsi. Nie znając turyńskich parafii, nie wiedząc, którym kolegom z pracy można zaufać, byli narażeni, zwłaszcza w dni świąteczne, na tysiące niebezpieczeństw moralnych"

Warunki życia tych młodych ludzi pozostawiały wiele do życzenia. Mieszkali po kilku lub kilkunastu w wynajętych, nędznych pomieszczeniach, większość nie umiała pisać ani czytać - dlatego łatwo byli wykorzystywani przez pracodawców. Z czasem ks. Bosco przejął na siebie pośrednictwo między znanymi sobie, godnymi zaufania majstrami i zatrudnianymi u nich młodymi ludźmi, pilnując, aby interesy tych ostatnich były respektowane. Przeprowadzał nawet swego rodzaju inspekcje, sprawdzając warunki, w jakich żyją i pracują. Wielu z nich znalazło później stałe schronienie przy Oratorium. Zarabiali niewiele, a niektórzy - bezrobotni, często opuszczeni i osieroceni - zgoła nic. Jak pisze Bonetti, „ks. Bosco musiał przeto starać się dla nich o wikt i dostarczać im odzieży i obuwia. W tym celu wychodził zwykle kilka razy w tygodniu na miasto i udając się to do tej to do owej, ze znanych powszechnie z dobroczynności osób, prosił pokornie dla nich o wsparcie"10. Ta kwesta przynosiła doraźną pomoc, ale nie mogła stanowić podstawy materialnej na dłuższy dystans.

W tym czasie zaniedbaną młodzieżąnie zajmował się we Włoszech prawie nikt, nawet Kościół, pomimo dużej liczby kapłanów (w 1860 r. było ich około 60 tys. $)^{11}$. Krytykowano ten stan rzeczy i tym bardziej doceniano tych kapłanów, którzy takiej działalności się podejmowali. Po kilku latach także

\footnotetext{
8 Tamże, s. 109.

9 Tamże.

10 J. Bonetti, Początki dzieła ks. Bosko, czyli 25-lecie oratorium, Ramsey 1921, s. 190.

11 Por. J. Niewęgłowski, Wychowawczo-społeczna działalność salezjanów w Polsce, dz. cyt, s. 49.
} 
ks. Bosco zyskał uznanie i materialne wsparcie również od władz, które generalnie do religii, do Kościoła i do jego instytucji nastawione były bardzo niechętnie.

Okres działalności ks. Bosco w Turynie to w dziejach Włoch czas walki o odzyskanie niepodległości i zjednoczenie, w której to walce główną rolę odgrywał Piemont, czyli Królestwo Sardynii. Turyn, jako jego stolica, stał się miastem, do którego już od lat trzydziestych XIX w. zaczęli ściągać zwolennicy zjednoczenia narodowego i reform społecznych. Jednym z nich był Roberto d’Azeglio, przyjaciel króla Karola Alberta i w przyszłości polityk odgrywający ważną rolę.

Karol Albert wiedział o działalności ks. Bosco oraz jego Oratorium i był bardzo przychylnie doń nastawiony. Jak pisze Bonetti: „[... [ kazał król Karol Albert księdzu Bosco już po kilka razy w imieniu swoim oświadczyć, jak wielce sobie ceni ten rodzaj duszpasterstwa [...] i wyrażał po kilkakroć życzenie, by we wszystkich miastach i wioskach Piemontu podobne oratoria świąteczne były dla młodzieży zaprowadzone” oraz „posyłał księdzu Bosco zapomogi i tak np. roku [1846-ego] posłał mu [...] 300 franków z żartobliwym dopiskiem: dla urwisów księdza Bosco”. „Mając więc - pisze dalej Bonetti - takiego protektora za sobą, oczywista rzecz, że Oratorium nie potrzebowało się nikogo i niczego obawiać"12.

Ten rodzaj duszpasterstwa, który tak cenił sobie król Karol Albert, łączył dwa elementy: religijny i rekreacyjny, wykorzystywany przez ks. Bosco także w celach religijnych. Wspominał: „Po wyjściu z kościoła zaczynał się wolny czas, który każdy spędzał jak chciał. Niektórzy dalej uczyli się katechizmu lub śpiewu czy czytania. Większość biegała i skakała do wieczora [...] Ja wykorzystywałem ten wolny czas, by choć trochę porozmawiać z każdym chłopcem. Jednemu polecałem na ucho, by był bardziej posłuszny, innemu, by bardziej przykładał się do katechizmu, innemu, by przyszedł się wyspowiadać, jeszcze innemu poddawałem jakąś myśl do refleksji itd. Mogę powiedzieć, że godziny rekreacji służyły mi do porozmawiania ze sporą ilością chłopców, którzy w następną sobotę wieczorem lub $\mathrm{w}$ niedzielę rano przychodzili do mnie z chęcią wyspowiadać się"13.

\footnotetext{
12 J. Bonetti, Początki dzieła ks. Bosko, dz. cyt., s. 91.

13 J. Bosko, Wspomnienia Oratorium, dz. cyt., s. 147.
} 
Chłopcy uczęszczający do Oratorium często nie umieli czytać i pisać, dlatego ks. Bosco utworzył z czasem niedzielną szkółkę wieczorową, w której początkowo sam uczył ich tych podstawowych umiejętności. $\mathrm{Z}$ czasem przerodziła się ona w szkółkę codzienną. O przyczynach tej zmiany tak pisał w swoich wspomnieniach: „Dla wielu chłopców szkółka niedzielna dawała dobre rezultaty, ale dla innych była niewystarczająca, ponieważ mieli bardzo słabą pamięć i w ciągu tygodnia zapominali to, czego się nauczyli w ostatnią niedzielę. I to właśnie skłoniło mnie do wprowadzenia codziennych lekcji wieczorem [...] Regularne lekcje wieczorowe miały podwójny efekt: zachęcały wielu chłopców do uczestnictwa, by zdobyć pilnie im potrzebną umiejętność pisania i czytania, a zarazem dawały wszystkim możliwość uczenia się religii, co było zasadniczym celem naszej pracy"14.

Bonetti pisze, że innym z celów tworzenia wieczorowych szkółek było „odciągnięcie chłopców od wieczornych niemoralnych rozrywek”. Ksiądz Bosco sam kształcił nauczycieli do tych szkółek spośród zdolniejszych chłopców. Po paru latach upowszechniły się one w całym Piemoncie ${ }^{15}$.

Po przeniesieniu Oratorium do dzielnicy Valdocco i pozyskaniu stałej siedziby, na początku 1847 r., ks. Bosco zajął się napisaniem Regulami$n u$, jaki miał obowiązywać jego wychowanków. Zawarł w nim wszystko to, co i tak, choć nieformalnie, obowiązywało w Oratorium. O tym Regulaminie tak pisał w swoich wspomnieniach: „Regulamin ten kazałem wydrukować i każdy mógł go przeczytać. Ten niewielki Regulamin oddał nam znaczne przysługi, bo każdy wiedział, co do niego należy. Zostawiałem każdemu pełną odpowiedzialność za sprawowaną przez niego funkcję. Dzięki Regulaminowi każdy dobrze wiedział za co odpowiada. Wielu biskupów i proboszczów poprosiło mnie o jego kopię i próbowali prowadzić według niego oratoria we własnych diecezjach i parafiach"16.

Regulamin jest ciekawym dokumentem pokazującym expressis verbis, jak ks. Bosco widział cele stojące przed Oratorium i drogi do nich prowadzące. Zgodnie z nim, Oratorium miało stanowić miejsce „zajęcia młodzieży w dni świąteczne po jej uczestnictwie w nabożeństwie miłą i godziwą rozrywką”. W punkcie pierwszym precyzowano, że „chodzi szczególnie o młodych robotników, którzy właśnie w dni świąteczne są bardzo narażeni na poważne moralne i cielesne niebezpieczeństwa”. Podkreślano,

\footnotetext{
14 Tamże, s. 147.

15 Por. J. Bonetti, Początki dzieła ks. Bosko, dz. cyt., s. 95-123.

16 J. Bosko, Wspomnienia Oratorium, dz. cyt., s. 165.
} 
że chodzi o rozrywkę tej młodzieży już po jej uczestnictwie w nabożeństwie, ,jako że zasadniczym celem jest nauka religii, reszta to tylko dodatek służący przyciągnięciu młodzieży”. Oratorium miało pozostawać pod opieką św. Franciszka Salezego, „ponieważ ci, którzy zamierzają się poświęcić tego typu działalności, powinni stawiać sobie tego właśnie świętego za wzór miłości i postępowania, dzięki czemu dzieło Oratorium może wydać takie owoce, których się spodziewamy"17. To ostatnie zdanie odnosiło się przede wszystkim do opiekunów młodzieży w Oratorium i wskazywało im sposób, w jaki mieli się nią opiekować.

Do Oratorium miano przyjmować wszystkich, bez względu na pochodzenie i pozycję społeczną, a przede wszystkim „najbiedniejszych, najbardziej opuszczonych i najmniej wykształconych, jako że oni właśnie potrzebują największej troski na drodze do życia wiecznego". Także tych dotkniętych różnymi dysfunkcjami, „Z wyjątkiem chorób zakaźnych i wyglądu, który mógłby wzbudzić w innych silny wstręt, ponieważ w takim wypadku z powodu jednej osoby mogłoby odejść z Oratorium wielu innych". Dolną granicą wieku przyjmowanych było osiem lat. Ks. Bosco przyzwalał także na przyjmowanie chłopców niezdyscyplinowanych, „o ile tylko nie będą siać zgorszenia i okażą chęć poprawy". W Regulaminie podkreślano, że Oratorium to instytucja o charakterze religijnym, w której chce się wychować „dobrych chrześcijan i uczciwych obywateli”, dlatego surowo zabraniano przeklinania i mówienia „rzeczy przeciwnych świętej wierze katolickiej”. Ci, którzy dopuściliby się tego rodzaju wykroczeń, mieli otrzymać za pierwszym razem „ojcowskie upomnienie”, ale gdyby nie okazali poprawy mieli zostać wykluczeni z Oratorium. Wszyscy powinni słuchać zarządzeń osób pracujących w Oratorium i właściwie się zachowywać. Jeden z punktów Regulaminu mówił o tym, że „młodzież powinna posiadać jakieś zajęcie czy pracę ponieważ bezczynność pociąga za sobą wszystkie wady i czyni daremną naukę religii”. Bezrobotni, a chcący pracować, mogli zwrócić się w tej sprawie do opiekunów Oratorium, którzy mieli im pomóc znaleźć pracę ${ }^{18}$.

W 1847 r. przysłano komisję państwową w celu wizytacji istniejącej przy Oratorium szkoły wieczorowej. Bardzo dobra ocena prowadzonej tam nauki sprawiła, że przyznano na dalszą działalność ks. Bosco 300 lirów dorocznej subwencji. W tymże roku otworzył ks. Bosco nowe oratorium pod wezwaniem św Alojzego, a w dwa lata później oratorium Anioła Stróża

\footnotetext{
17 Tamże, s.167-168.

18 Por. tamże.
} 
- na przedmieściu turyńskim Vanchiglia, znanym, podobnie jak Valdocco, z bardzo dużej przestępczości ${ }^{19}$.

Okres po 1847 r. to czas doniosłych przemian w życiu społecznym i politycznym całego Półwyspu Apenińskiego. Kolejne państewka włoskie wprowadzały konstytucje gwarantujące wolności obywatelskie. W Królestwie Sardynii miało to miejsce w marcu 1848 r. Jednocześnie nastąpił konflikt z Austrią okupującą część terytorium włoskiego i sprzeciwiającą się dążeniom do zjednoczenia państewek włoskich pod berłem, rezydującego w Turynie, Karola Alberta. Gorączka polityczna dotknęła także duchowieństwo. Na ulicach Turynu pojawili się księża i seminarzyści, którzy demonstrowali z przypiętymi trójkolorowymi kokardami swoje poparcie dla reformy konstytucyjnej i walki z Austriakami. Nastrój ten ogarnął także oratoria ks. Bosco. Jeden z młodych księży pomagających w Oratorium wygłosił chłopcom kazanie na temat wolności, niepodległości i wojny z Austrią, po czym rozwinął sztandar o barwach narodowych, przypiął sobie kokardę i wyszedł demonstracyjnie, pociągając za sobą dużą grupę młodzieży ${ }^{20}$.

Ks. Bosco znalazł się w trudnej sytuacji, zwłaszcza że władze, wspomagające materialnie jego działalność, domagały się od niego popierania swoich działań. Wspomniany już przyjaciel króla, markiz Roberto d'Azeglio, główny inicjator manifestacji popierających nadanie konstytucji, złożył ks. Bosco formalne zaproszenie do udziału w takiej manifestacji wrazz wychowankami Oratorium, ofiarowując odpowiednie stroje, aby cała grupa dobrze się prezentowała. Na turyńskim Piazza Vittoria przygotowano im odpowiednie miejsce obok innych instytucji turyńskich. „Co robić? - zastanawiał się ks. Bosco. Odmówić - oznaczało zadeklarować się wrogiem Włoch, zgodzić się - to zaakceptować zasady, które uważałem za zbyt niebezpieczne"21.

Jak pisze ks. Bonetti, po 1848 r. daje się zauważyć poruszenie wśród chłopców, zwłaszcza w związku z wojną z Austrią. Niektórzy poszli walczyć na ochotnika, mniej chłopców zaczęło przychodzić do Oratorium, „liczba zaś przystępujących do sakramentów [...] niesłychanie spadła”. Podjęto więc pewne środki zaradcze. „Ks. Bosco pozwolił swoim chłopcom musztrować się i wyprawiać harce na dziedzińcu Oratorium, a nawet postarał się im o znaczny zapas starych karabinów, wprawdzie bez kurka i lufy, ale za to zaopatrzonych w kije do nabijania. Położył jednak warunek

\footnotetext{
19 Por. A. Auffray, Święty Jan Bosko, dz. cyt., s. 50-51.

20 Por. tamże, s. 51

21 J. Bosko, Wspomnienia Oratorium, dz. cyt., s. 185.
} 
naprzód, żeby sobie nawzajem nie wymierzali razów i bolesnych cięgów, jak to zazwyczaj czynili «Piemontczycy» w walce $\mathrm{z}$ «Austriakami», a po wtóre, żeby na odgłos dzwonka, wzywającego na katechizm, każdy wojak natychmiast stawiał broń w kozły i spieszył do kaplicy"22.

Nowa konstytucja w Piemoncie, przyznając wszystkim obywatelom wolność wyznania, zapoczątkowała jednocześnie proces laicyzacji życia społecznego, co doprowadziło do konfliktu władz państwa z Kościołem, niechętnie przyjmującego liberalne reformy, zwłaszcza te ograniczające jego możliwości oddziaływania. Należało do nich m.in. religijne równouprawnienie żydów i protestantów. Coraz częściej atakowano, nawet fizycznie, samego ks. Bosco i innych księży. Ks. Bosco zwracał uwagę na coraz większe zobojętnienie religijne w społeczeństwie, a zwłaszcza negatywny wpływ tych nowych trendów na młodzież. Pisał: „Swego rodzaju szał ogarnia umysły nawet młodzieży, która gromadzi się w różnych punktach miasta, na drogach i na placach, uważa za coś dobrego wszelką zniewagę księdza czy religii”23.

Ks. Bonetti oceniał, że w sytuacji ogólnowłoskich - narodowych, liberalnych i antyreligijnych - dążeń system wychowawczy tworzony przez ks. Bosco po prostu nie mógł być inny. Pisał: „Powszechne te dążenia do wolności i gorące pragnienie ludów większych swobód, tudzież form rządu łagodniejszych [...] znalazły odgłos w umysłach młodzieży, która również zaczęła domagać się łagodniejszego i ojcowskiego sposobu obchodzenia się z nią ze strony zwierzchników. System przeto wychowawczy ostry, karcący, który w innych czasach może byłby na miejscu i owszem wcale niezłe przynosiłby owoce, wówczas sprzeciwiał się najwyraźniej powszechnemu nastrojowi umysłów, czyli (jak się zwykło mówić) «duchowi czasu», a odnośnie do zakładu i wychowywanej tamże młodzieży wyrządziłby obojgu następujące dwie niepowetowane szkody. Nasamprzód odstręczyłby młodzież od oratorium [...] Po wtóre utwierdziłby tylko młodzież w przekonaniu o prawdziwości szeroko wśród pospólstwa rozpowszechnionych zarzutów [...], że księża są «tyranami, krzewicielami ciemnoty, nieprzyjaciółmi wszelkiego postępu, wrogami wolności ludu»"24.

Antyklerykalne nastawienie rządzących doprowadziło w $1855 \mathrm{r}$. w Królestwie Sardynii do zamykania klasztorów i kasaty poszczególnych

\footnotetext{
22 J. Bonetti, Początki dzieła ks. Bosko, dz. cyt., s. 180.

23 J. Bosco, Wspomnienia Oratorium, dz. cyt., s. 187.

${ }^{24}$ J. Bonetti, Początki dzieła ks. Bosko, dz. cyt., s. 202.
} 
zakonów. Zlikwidowano w sumie 34 zakony z 334 domami i 4500 zakonnikami, przeważnie te, które nie zajmowały się kaznodziejstwem, nauczaniem i wychowaniem oraz opieką nad chorymi. Pozostawiono 22 instytuty zakonne z 274 domami i około 4000 zakonników ${ }^{25}$. Wkrótce za tym przykładem poszły inne państewka włoskie. Tymczasem w odniesieniu do działalności ks. Bosco, która miała przecież charakter przede wszystkim religijny, władze, generalnie rzecz biorąc, chętnie udzielały finansowego i organizacyjnego wsparcia, widząc jej niezaprzeczalne znaczenie publiczne, społeczne i biorąc pod uwagę, że odciąża w ten sposób państwo w jego powinnościach. Bonetti przytacza słowa głównego orędownika zjednoczenia Italii pod berłem dynastii sabaudzkiej i premiera - Camillo Cavoura - który miał mawiać o oratorium ks. Bosco: „Doprawdy, życzyć by sobie należało, ażeby w każdym mieście stanął przynajmniej jeden taki zakład. Wtenczas wielu chłopców uniknęłoby więzienia, a skarb państwa nie ponosiłby tyle wydatków na utrzymywanie po więzieniach nicponi i próżniaków; z takich zaś zakładów wychodziliby spokojni i prawi obywatele kraju, którzy wyćwiczywszy się za młodu w jakimś zawodzie lub rzemiośle, zarabialiby potem w sposób uczciwy na kawałek chleba z pożytkiem dla siebie samych i dla całego społeczeństwa" ${ }^{26}$.

Jednak stały konflikt między Państwem a Kościołem, jaki w tym czasie miał miejsce, dotknął także Oratorium. Władze podejrzewały, że stanowi ono ośrodek klerykalnej i antypaństwowej konspiracji utrzymującej kontakty z papieżem Piusem IX, jezuitami i usuniętym z urzędu arcybiskupem Turynu. W maju i w czerwcu 1860 r. przeprowadzono w nim dwukrotnie rewizję, a jego mieszkańców poddano 7 -godzinnemu przesłuchaniu ${ }^{27}$. W związku z tymi faktami, ks. Bosco wystosował do ministra spraw wewnętrznych pismo, w którym określił stosunek swój i kierowanego przez siebie zakładu do ówczesnych wydarzeń politycznych. Pisał: „Stałem zawsze poza wszelką polityką; nie wtrącałem się nigdy ani za, ani przeciw prądom współczesnym. Owszem, dla uniknięcia prądów partyjnych zabrania się [w Oratorium] mówić jakkolwiek o polityce. [...] Uważałem za konieczne to zarządzenie, aby kapłan mógł spełniać swój urząd miłosierdzia chrześcijańskiego względem bliźnich [...] mogę z całą stanowczością zaznaczyć, żem nigdy nie powiedział, ani nie

\footnotetext{
${ }^{25}$ Por. J. Niewęgłowski, Wychowawczo-społeczna działalność salezjanów w Polsce, dz. cyt., s. 37.

26 Tamże, s. 186.

27 Por. A. Auffray, Święty Jan Bosko, dz. cyt., s. 143.
} 
uczynił, ani nie wmawiał nic takiego, co by się sprzeciwiało ustawom państwowym"28.

Władze nie tylko wspierały materialnie dzieło ks. Bosco, ale nawet, w tym okresie likwidowania instytucji zakonnych, sugerowały powołanie zgromadzenia, które mogłoby zająć się kontynuowaniem i rozszerzeniem prowadzonej przez niego działalności. Inicjatywa $\mathrm{w}$ tej mierze ks. Bosco, wsparta przez papieża, doprowadziła do powstania Zgromadzenia Św. Franciszka Salezego. Pierwsi salezjanie zostali powołani spośród chłopców mieszkających, uczących się i pracujących przy Oratorium.

To przede wszystkim z myślą o salezjanach - kontynuatorach jego działalności - przygotował ks. Bosco zalecenia odnoszące się do Systemu zapobiegawczego. Było to w roku 1877, a więc u kresu życia i dokonań Świętego. Zawarł w nim, w bardzo krótkiej i ogólnej formie, podstawowe zasady wywodzące się $\mathrm{w}$ dużej mierze $\mathrm{z}$ jego doświadczeń, związanych z kierowaniem Oratorium w gorącej atmosferze ówczesnych przemian społecznych i politycznych. Miał to być system zapobiegawczy, a nie represyjny. Wychowankowie mieli być chronieni od złego - tak jak to miało miejsce na Valdocco, gdzie internat, szkoła i pracownie powstawały w dużej mierze po to, aby uchronić chłopców od zgubnych wpływów miasta. Pewną rolę odegrały tu także wczesne doświadczenia ks. Bosco z wychodzącymi z więzień chłopcami, którzy bez odpowiedniej opieki łatwo mogli wrócić na drogę przestępstw. Stąd potrzeba asystencji - stałego przebywania opiekunów i udziału w życiu wychowanków. Lepiej i łatwiej jest zapobiegać niż walczyć ze złem.

W tych zaleceniach ks. Bosco położył nacisk na rozum i religię, rozumiane bardzo praktycznie - zgodnie z dotychczasową działalnością Oratorium i zakładów z nim powiązanych. Dotyczy to zwłaszcza religii. Zdaniem ks. Bosco, „częsta spowiedź, częsta Komunia św., codzienna Msza św. - oto filary, na których musi się wspierać gmach wychowania, jeśli od niego chce się z dala trzymać groźbę i rózgę". Atmosfera radości i zaufanie wobec wychowawcy miały być podbudową tej pobożności. Celem było „wychowanie obywatelskie, moralne i umysłowe młodzieży" 29 .

${ }^{28}$ Cyt. za J. Bonetti, Początki dzieła ks. Bosko, dz. cyt., s. 464.

29 J. Bosco, System zapobiegawczy w wychowaniu młodzieży, w: L. Cian, System zapobiegawczy św. Jana Bosko, tłum. M. Gabryel, Wyd. Salezjańskie, Warszawa 1986, s. 230, 231. 
Jednak najważniejszym elementem tego oddziaływania miała być miłość wychowawcza. Miłość wychowawcza praktykowana w Oratorium przez samego ks. Bosco. Jeden z jego wychowanków, późniejszy przełożony generalny Towarzystwa Salezjańskiego Paolo Albera, napisał: „Ksiądz Bosco kochał nas w sposób autentyczny i wyłączny: miał w sobie jakąś niespotykaną zdolność oczarowywania; czułem się jakoś owładnięty jego uczuciem w zakresie myśli, słów i czynów; doświadczyłem, że jestem kochany jak nigdy dotąd"30.Temu zagadnieniu poświęcony był list ks. Bosco do salezjanów z Rzymu z 10 maja 1884 roku, w którym w zawoalowanej formie krytykował brak tej miłości w ówczesnej praktyce wychowawczej swoich kontynuatorów. Zdaniem ks. Bosco, wychowankowie powinni czuć, że są kochani ${ }^{31}$.

Tak jak wspomniałem we wstępie, trudno jest mówić o jakimś systemie wychowawczym autorstwa ks. Bosco. Były to raczej wskazówki, sugestie, wypływające z praktycznych przesłanek (także tych społecznych i politycznych). Prześwietlone miłością do wychowanków oraz intuicją wychowawczą sprawiały, że wychowanie w ujęciu ks. Bosco stawało się sztuką niełatwą do opanowania.

30 Cyt. za J. Niewęgłowski, Wychowawczo-społeczna działalność salezjanów w Polsce, dz. cyt., s. 87.

31 Por. List św. Jana Bosko o stanie Oratorium, w: L. Cian, System zapobiegawczy, dz. cyt., s. $252-253$. 
$\$$ 


\section{K. Zenon Lataviec SDB}

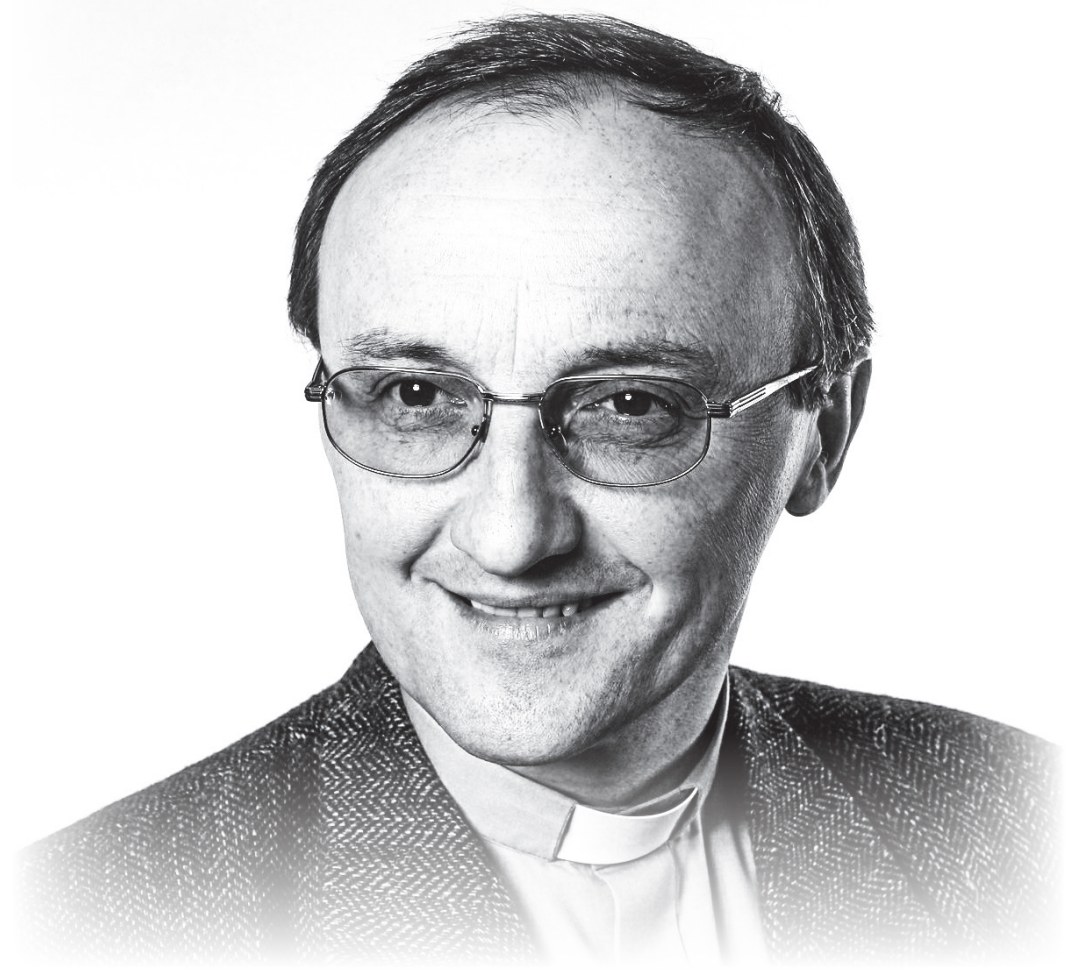

pierwszą profesję zakonną złożył w 1983 r. w Kopcu. Święcenia kapłańskie przyjął w 1990 w Krakowie. W latach 1990-1992 pracował jako kierownik oratorium w Przemyślu. W 1992-1993 w Oświęcimiu - jako kierownik internatu. W latach 1992-2000 był wicedyrektorem zespołu szkół zawodowych w Oświęcimiu. W 2000 roku został dyrektorem zespołu szkół w Świętochłowicach i dyrektorem wspólnoty. Po sześciu latach został skierowany do Polany (Bieszczady), gdzie - jako dyrektor - organizował nowo przejętą szkołę podstawową. Rok później przełożeni skierowali go do Oświęcimia, gdzie do dziś jest dyrektorem zespołu szkół zawodowych towarzystwa salezjańskiego. Od 2013 roku jest także przewodniczącym rady szkół katolickich. 


\section{Aktualność systemu prewencyjnego św. Jana Bosko w szkołach salezjańskich}

Stworzony i stosowany w praktyce przez ks. Jana Bosko system prewencyjny ma wiele aspektów, które we współczesnym szkolnictwie salezjańskim mają ogromne znaczenie. Przedstawione w niniejszym artykule wnioski i spostrzeżenia są głosem praktyka, owocem dwudziestotrzyletniej pracy w szkołach salezjańskich w Oświęcimiu, Świętochłowicach i Polanie. Pełnione w tych placówkach obowiązki, a szczególnie praca w Zespole Szkół Zawodowych Towarzystwa Salezjańskiego w Oświęcimiu, złożyły się na bogate doświadczenie i zrozumienie istoty systemu wychowawczego św. Jana Bosko. Na bazie tego doświadczenia śmiało można stwierdzić, że opracowany w połowie XIX w. system prewencyjny nie tylko się nie zdezaktualizował, ale wciąż stanowi żywy wzorzec wychowania młodzieży, szczególnie aktualny w czasach kryzysu wartości i autorytetów.

\section{Działanie wspólnotowe podstawą sukcesu w pracy wychowawczej}

Ksiądz Bosko, podejmując zadanie pracy z młodzieżą, miał świadomość, że nie jest w stanie samotnie podołać temu wyzwaniu. Od samego początku poszukiwał ludzi, którzy pomagaliby mu w realizacji jego misji. Aby zapewnić wychowankom lepsze warunki, nie zawahał się nawet zaproponować swojej mamie Małgorzacie funkcji gospodyni w domu salezjańskim. Praca wspólnotowa była podstawą dzieła, które rozrosło się na cały świat.

Trudno sobie dziś wyobrazić szkołę salezjańską bez współpracy z osobami spoza zgromadzenia, jednak równie silnie zaangażowanymi w działalność wychowawczą w duchu księdza Bosko. To kompetencje poszczególnych jednostek ukierunkowane na wspólny cel, jakim jest praca z młodzieżą i na rzecz młodzieży, spowodowały tak imponujący sukces salezjańskiego systemu wychowawczego. 
W Polsce szkoły salezjańskie zrzeszone są w Radzie Szkół Katolickich, którą powołała Konferencja Episkopatu Polski w 1994 r. Zarząd Rady podejmuje różnego rodzaju działania na rzecz szkół katolickich, między innymi czuwa nad zmianami w prawie oświatowym oraz inicjuje spotkania dyrektorów szkół. Spotkania te mają charakter formacyjno-informacyjny i odbywają się trzy razy do roku: w sierpniu, listopadzie i w marcu. Działalność Rady obejmuje także organizację Forum Szkół Katolickich dla nauczycieli. Ma ono miejsce podczas listopadowego spotkania dyrektorów na Jasnej Górze. W trosce o wysoką jakość procesu wychowawczego i w odpowiedzi na bieżące problemy związane z pracą wśród młodzieży zarząd zaprasza na Forum odpowiednich prelegentów, którzy dzielą się swoim doświadczeniem oraz wiedzą z nauczycielami i wychowawcami szkół katolickich. Ważnym elementem każdego Forum jest spotkanie nauczycieli i dyrektorów na wspólnej Mszy św. w Kaplicy Cudownego Obrazu.

Co roku we wrześniu Zarząd organizuje także Forum Młodzieżowe, w którym uczestniczą wychowankowie szkół katolickich, w tym salezjańskich. Na Jasnej Górze, u stóp Czarnej Madonny, gromadzi się wówczas około 2000 młodych ludzi, którzy uczestniczą w prelekcjach i wykładach przygotowanych właśnie $\mathrm{z}$ myślą o potrzebach współczesnej młodzieży. Uczestnictwo w Forum to także okazja do zasmakowania we wspólnocie, radosnej atmosferze, jaką tworzą młodzi samą swoją obecnością. To możliwość refleksji nad tym, co w dzisiejszym świecie warte jest uwagi, a co stanowi realne zagrożenie. To wreszcie szkoła modlitwy, bez której system prewencyjny nie mógłby właściwie działać.

Innym organem wspierającym działalność szkół prowadzonych przez salezjanów jest Federacja Szkół Salezjańskich. Ma ona charakter stowarzyszenia, którego celem jest umacnianie tożsamości salezjańskiej i koordynacja współpracy placówek znajdujących się w obrębie sześciu inspektorii (2 inspektorie Zgromadzenia Córek Maryi Wspomożycielki i 4 inspektorie Towarzystwa Salezjańskiego). Federacja organizuje spotkania wyznaczonych przez inspektorów przedstawicieli odpowiedzialnych za szkolnictwo. W ten sposób narodziła się idea pierwszego kongresu dyrektorów szkół salezjańskich w Polsce, podczas którego doszło do istotnej wymiany doświadczeń związanych z pracą w szkołach, przedszkolach i ośrodkach wychowawczych. Pozwoliło to każdemu uczestnikowi uświadomić sobie, jak wielką rzeszę młodzieży obejmujemy w pracy szkolnej, a tym samym, z jaką odpowiedzialnością podejmujemy trud wychowawczy i kształcący. $\mathrm{Na}$ 
kongresie zapadła decyzja o organizacji pielgrzymki dziękczynnej za działalność i życie św. Jana Bosko na Jasną Górę. Pielgrzymka ta odbędzie się 16 września 2015, w ramach tygodnia wychowania ogłoszonego przez Episkopat Polski, a poświęconego w tym roku - roku jubileuszowym - systemowi prewencyjnemu św. Jana Bosko.

Istnieją również europejskie struktury szkolnictwa salezjańskiego. Należy do nich między innymi Europejska Komisja Szkolnictwa Salezjańskiego. W jej skład wchodzą odpowiedzialni za szkoły salezjańskie przedstawiciele poszczególnych krajów Europy. W ramach prac komisji przygotowane zostały materiały ankietowe, które monitorują, na ile szkoły prowadzone przez salezjanów i siostry salezjanki realizują posłannictwo św. Jana Bosko. Inną organizacją jest Komisja Szkolnictwa Zawodowego. Pracują w niej wyłącznie salezjanie odpowiedzialni za szkolnictwo zawodowe w Europie. Trzecią wreszcie komisję tworzą osoby działające przy szkołach salezjańskich i zajmujące się projektami europejskimi. Spotkania poszczególnych komisji odbywają się raz w roku i pozwalają na dzielenie się zdobytym doświadczeniem w pracy w różnych krajach i przenoszenie dobrych wzorców do poszczególnych placówek.

Wymienione wyżej struktury mają pomóc ośrodkom edukacyjnym $\mathrm{w}$ realizowaniu podstawowego zadania wynikającego z przesłania św. Jana Bosko - wychowywać młodzież na uczciwych obywateli i dobrych chrześcijan. Szkoła będąca podstawową organizacją edukacyjną musi również opierać swoją działalność na konkretnych osobach i relacjach między nimi, gdyż właśnie osoby i właściwe relacje tworzą przyjazne dla młodego człowieka środowisko szkolne. Są to wychowawcy, nauczyciele, wszyscy pracownicy i rodzice. Bardzo ważne jest, aby wszyscy mieli świadomość, na czym polega tworzenie tego środowiska. We wspólnocie każdy ma określoną rolę do spełnienia, dlatego jednym z podstawowych zadań, jakie wynikają z systemu prewencyjnego ks. Bosko, jest zrozumienie tej roli i odpowiedzialność za właściwie wykonywanie powierzonych obowiązków. Stąd tak istotny w środowiskach szkolnych jest sposób informowania i wzajemnego komunikowania się. W Oświęcimiu, gdzie zatrudnionych jest ponad 90 nauczycieli, korzystamy z platformy internetowej pozwalającej na szybkie komunikowanie się w sprawach organizacji pracy i procesu dydaktycznego.

Ważnym zadaniem dyrektora wspólnoty jest również rozpoznanie predyspozycji i możliwości poszczególnych osób. Warto dostrzec tych, którzy chcą czegoś więcej i zaproponować im bycie salezjaninem współpra- 
cownikiem. Jest to droga, którą wyznaczył nam ks. Bosko. W ten sposób on sam trafiał do konkretnych osób, które przygotowywał do podejmowania zadań związanych z formacją młodzieży.

Szczególnie istotnym w obecnych czasach elementem wychowania salezjańskiego jest angażowanie rodziców w życie szkoły. Nie jest to rzecz łatwa, ale możliwa. W Oświęcimiu rodzice wraz z młodzieżą organizują majowy piknik rodzinny pod hasłem „Rodzina największą wartością”. Impreza ta cieszy się bardzo dużym zainteresowaniem, o czym świadczy fakt, że w tym roku piknik odbył się już po raz szósty. Atmosfera tego rodzinnego święta pozwala każdemu uczestnikowi dobrze spędzić sobotnie popołudnie w gronie najbliższych - rodziców, dziadków, a także przyjaciół i znajomych. Atrakcje sportowe i kulturalne zbliżają do siebie ludzi spoza środowiska szkolnego, dzięki czemu salezjański piknik stał się wydarzeniem lokalnym.

\section{Szkolnictwo zawodowe priorytetem systemu prewencyjnego}

Ksiądz Bosko zakładał szkoły zawodowe, ponieważ taka szkoła przygotowywała młodych ludzi do podjęcia pracy. Współcześnie młodzież kończąca edukację napotyka na poważne problemy ze znalezieniem zatrudnienia. Dlatego szkoła salezjańska, uwzględniając reformę szkolnictwa zawodowego, musi podjąć wyzwanie kształcenia zawodowego z wielkim zaangażowaniem i odpowiedzialnością. Młody człowiek musi być przygotowany do wejścia na rynek pracy. Absolwent opuszczający mury szkoły salezjańskiej powinien być uzbrojony w kwalifikacje zawodowe, które pomogą mu znaleźć zatrudnienie. Szkoła zawodowa może i powinna proponować zdobycie pożądanych obecnie kwalifikacji. Niestety, młodzi ludzie bardzo często są zagubieni i nie potrafią określić, co chcieliby w życiu robić, jakie mają predyspozycje do wykonywania danego zawodu. Dlatego niezbędne jest prowadzenie na każdym poziomie edukacji doradztwa zawodowego.

$\mathrm{W}$ odpowiedzi na zmiany $\mathrm{w}$ prawie oświatowym związanym z kształceniem zawodowym w Oświęcimiu powstało Salezjańskie Centrum Kształcenia Ustawicznego. Umożliwia ono zarówno naszym absolwentom, jak i osobom z zewnątrz zdobywanie nowych kwalifikacji wymaganych na rynku. Ważnym elementem tego przedsięwzięcia jest zadbanie o wprowadzenie wychowanka do właściwego zakładu pracy. W tym celu organizujemy podczas wakacji tzw. prace stażowe - uczeń przez miesiąc pracuje we wskazanym zakładzie pracy i w ten sposób daje się poznać pracodawcy. 
Taka sama procedura stosowana jest podczas miesięcznych praktyk zawodowych realizowanych w ramach podstaw programowych. Uczniowie odbywają praktyki u pracodawców w kraju i za granicą (Włochy, Hiszpania).

\section{Oratorium podstawą wychowania}

Trudno sobie wyobrazić szkołę salezjańską bez oratorium. To właśnie w oratorium młodzież szkolna i pozaszkolna może znaleźć sposób na zagospodarowanie czasu wolnego, a zarazem może rozwijać swoje talenty. Tu uczniowie, czekając na autobus po lekcjach, mogą odrobić zadania, swobodnie rozmawiać, bawić się. Część $\mathrm{z}$ nich jest zaangażowana $\mathrm{w}$ wolontariat prowadzony przez przygotowanych do takiej działalności animatorów. Oświęcimskie oratorium animuje wiele spotkań o charakterze kulturalnym: muzycznym, teatralnym, literackim czy filmowym. Stałym elementem programu oratorium stały się czwartkowe wieczory muzyczne, podczas których prezentują się zarówno profesjonaliści, jak i amatorzy, najczęściej uczniowie szkoły pragnący rozwijać swoje talenty i zmierzyć się, zwykle po raz pierwszy, z występem przed większą publicznością.

Animatorzy oratorium, angażując się $\mathrm{w}$ prowadzenie zimowisk i półkolonii dla dzieci z miasta i okolic, przygotowują się do pracy na rzecz innych, kształcą umiejętności organizacyjne, zdobywają doświadczenie i praktykę, która może okazać się pomocna w ich rozwoju i wyborze drogi życiowej.

Oratorium wychodzi również do całej społeczności szkolnej z różnego rodzaju inicjatywami, takimi jak akcja „Bucik”, która polega na odmawianiu jednego dziesiątka różańca każdego dnia za dzieci poczęte, a jeszcze nienarodzone.

Animowanie takich imprez, jak noc misyjna czy zwiedzanie zakładu salezjańskiego w ramach miejskiej Nocy Muzeów, współorganizowanie obozów integracyjnych dla nowo przyjętych uczniów, Dni Radości podczas roku szkolnego i wielu innych sprawia, że oratorium postrzegane jest jako integralna część życia szkoły.

\section{Trzy filary systemu prewencyjnego}

System prewencyjny św. Jana Bosko oparty na trzech filarach, jakimi są rozum, religia i miłość, jest realizowany każdego dnia, począwszy 
od tak zwanego „słówka”. Św. Jan Bosko nauczył się od swojej mamy Małgorzaty, że warto na zakończenie dnia skierować do swoich wychowanków jakąś krótką pogadankę. Nazwał to „słówkiem wieczornym”. Od tego czasu słówko stało się elementem systemu prewencyjnego, zachowało swoją formę, choć zmieniła się pora jego wygłaszania. Ze względu na tryb pracy szkoły, nie można tego słówka kierować do młodzieży wieczorem, ponieważ uczniowie są w domach rodzinnych. Dlatego słówko jest wygłaszane na porannym apelu przed rozpoczęciem zajęć szkolnych. Głoszą je w kolejnych dniach tygodnia dyrektorzy, nauczyciele, katecheci i sami uczniowie. Nie da się ukryć, że słówko ma bardzo duży wpływ na proces wychowawczy realizowany w szkole.

Życzeniem ks. Bosko było, aby każda wspólnota salezjańska tworzyła klimat rodzinny, aby każdy, kto przynależy do tej wspólnoty, czuł się w niej dobrze i bezpiecznie. Będzie to możliwe tylko wtedy, gdy wszyscy jej członkowie będą w stanie łaski uświęcającej. Sakrament pojednania to bardzo ważny moment $\mathrm{w}$ procesie wychowawczym. Uczniowie (a także nauczyciele i pracownicy) codziennie mogą skorzystać z sakramentu pojednania. Każdego dnia podczas długiej przerwy w konfesjonale przy kaplicy domowej dyżuruje spowiednik. Przed świętami wielkanocnymi, w Wielkim Tygodniu, od poniedziałku do środy, na lekcji religii uczniowie uczestniczą w nabożeństwie pokutnym i korzystają z tego sakramentu. Wychowankowie internatu uczestniczą każdego dnia we Mszy św. porannej.

Właściwie przeprowadzone i przemodlone rekolekcje szkolne, dobrze przygotowane i przeżyte szkolne Msze św. (9 Mszy św. w ciągu roku szkolnego) przynoszą dużo dobrego w formacji duchowej młodych ludzi poszukujących w szkole nie tylko wykształcenia, ale także wskazówek, jak żyć, na jakich wartościach budować swoją przyszłość.

Patrząc z perspektywy wielu lat przepracowanych w szkole salezjańskiej, mogę śmiało stwierdzić, że środowisko szkolne, pomimo swoich z góry określonych struktur, jest bardzo dobrym miejscem na realizowanie systemu prewencyjnego św. Jana Bosko. Realizacja ta zależy od właściwego nakreślenia priorytetów, od osób realizujących te priorytety, odważnie poszukujących najlepszych rozwiązań, które pomogą młodzieży znaleźć właściwą drogę w życiu, odkryć i zrealizować wszystkie talenty, którymi Bóg obdarza każdego człowieka. 
$\$$ 


\section{K. Jan Niewegforski SDB}

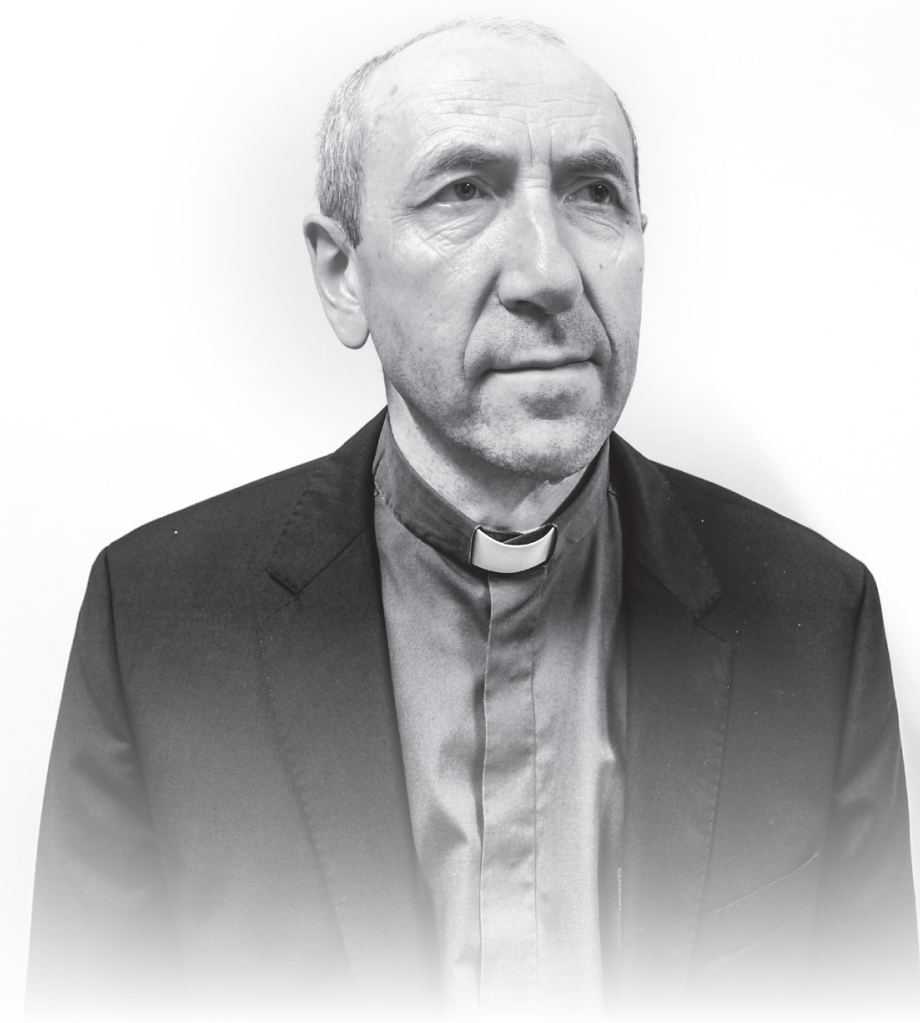

urodzony w 1960 r. w Zakrzewie, woj. lubelskie, salezjanin, wykładowca pedagogiki w Uniwersytecie Kardynała Stefana Wyszyńskiego w Warszawie. Absolwent Katolickiego Uniwersytetu Lubelskiego i Salezjańskiego Uniwersytetu Papieskiego w Rzymie. Prowadzi wykłady w salezjańskim Wyższym Seminarium Duchownym w Ladzie nad Wartą. Ważniejsze publikacje naukowe: Religia $i$ wychowanie w myśli Luigiego Stefaniniego, Warszawa 2009; Działalność wychowawczospołeczna Salezjanów w Polsce w latach 1898-1989, Warszawa 2012. 


\section{Teologiczno-pedagogiczne uwarunkowania sportu salezjańskiego}

W 1878 r. ks. Jan Bosko spotkał się w Turynie ze współpracownikami salezjańskimi. W swoim przemówieniu do nich powiedział: „Chcecie zrobić dobrą rzecz? Wychowujcie młodzież. Chcecie zrobić rzecz świętą? Wychowujcie młodzież. Chcecie uczynić rzecz najświętszą? Wychowujcie młodzież. Chcecie uczynić rzecz boską? Wychowujcie młodzież. A ta, wśród rzeczy boskich, jest wręcz najbardziej boską"1. W przypadku ks. Bosko, można powiedzieć, że powyższe przekonanie wcielił w życie osobiście jako wypełnienie obietnicy z początku jego dzieła: „Przyrzekłem Panu Bogu, że nawet ostatni mój oddech będzie dla moich biednych chłopców"2.

Turyński Wychowawca swoją metodę wychowawczą oparł na trzech filarach: rozumie, religii, miłości ${ }^{3}$. Zasada rozumności to roztropność wychowawcy w relacjach $\mathrm{z}$ wychowankami. Zasada miłości to troska wychowawcy o pełny rozwój wychowanka i pragnienie dla niego dobra ludzkiego i nadprzyrodzonego. Wychowawca z Turynu był przekonany, że warunkiem skuteczności wychowania jest religia. Zasada ta, obecna w procesie wychowania, decyduje o treści, formie i środkach wychowania. Religii ks. Bosko wyznaczał główne zadanie wiązania i łączenia w jedno rozumu i miłości. Ksiądz Bosko chciał, aby religia ukierunkowywała wychowanka na perspektywę eschatologiczną, poprzez realizację ideału świętości ${ }^{4}$.

Włoski filozof, Francesco Orestano (1873-1945), pisał o ks. Janie Bosko. „Jeśli o św. Franciszku można powiedzieć, że uświęcił przyrodę i ubó-

1 E. Ceria, Memorie Biografiche, Societá Editrice Internazionale, Torino1898-1948, t. XIII, s. 629.

2 Tamże, t. XVIII, s. 258.

3 Por. G. Bosco, Il metodo preventivo, La Scuola, Brescia 1940, s. 189.

${ }^{4}$ Por. P. Braido, L'esperienza pedagogica di don Bosco, LAS, Roma 1988, s. 131. 
stwo, to o św. Janie Bosko trzeba opowiedzieć, że uświęcił pracę i radość. [...] Nie zdziwiłbym się, gdyby ks. Bosko został ogłoszony świętym patronem gier, zabaw i współczesnych sportów"s. Nawet jeśli władze kościelne nie wypowiedzą się na ten temat, to zawsze osobom zajmującym się wychowaniem Jan Bosko będzie się kojarzył ze świętym radosnym, uśmiechniętym i obecnym na boisku z wychowankami. Dlatego boisko jest również nieodłącznym elementem domów salezjańskich i dzieł prowadzonych tak przez salezjanów, jak i przez siostry salezjanki. W tym kontekście pojawia się termin salezjański - Salezjańska Organizacja Sportowa. Należy już tutaj dookreślić powyższy termin, aby był właściwie zrozumiały. Nie chodzi o sport jako o dziedzinę życia czy możliwość zajęcia czasu młodzieży. Należy pytać o miejsce rekreacji/sportu w systemie wychowawczym ks. Bosko ${ }^{6}$. Specyfika podejścia salezjańskiego, to przekonanie wychowawcy o nieodzownej roli aktywności fizycznej w procesie formowania dobrego chrześcijanina i uczciwego obywatela. Rekreacja/sport to jeden ze środków, dość skutecznych, do osiągnięcia przez ucznia/wychowanka świętości. Jan Paweł II, w liście do salezjanów Ojciec i nauczyciel młodzieży z 1988 r., pisze: „W związku z tym warto przynajmniej przypomnieć, jak wiele dawał Święty miejsca momentom rekreacji, z jaką powagą traktował sport, muzyke, teatr, albo - jak zwykł był mówić, podwórko. Właśnie w takich sytuacjach przenikliwy wychowawca potrafi delikatnie i skutecznie oddziaływać na trwałość i klimat przyjaźni, w jakim to wszystko się odbywa"”.

Z łatwością można zauważyć obecność sportu/rekreacji w życiu małego Janka Bosko. W tym okresie jego życia bardziej widoczny jest akcent pedagogiczny, chociaż przeplata się z nim niekiedy wymiar religijny/teologiczny. Jego dzieciństwo nie odbiegało od dzieciństwa jego rówieśników. Janek Bosko nie skupiał się tylko na modlitwie czy nauce, ale brał udział we wszystkich zajęciach właściwych jego wiekowi. Czynił to $\mathrm{z}$ radością i entuzjazmem. Dlatego też jego dzieciństwo i wczesna młodość to czas przygotowywania się do roli przyszłego wychowawcy. „Pierwsza cecha, mówi ks. Juan Vecchi, jaka uwidacznia się w życiu Janka Bosko, to spontaniczna zdolność do cieszenia się i w tym samym czasie do wyrażania siebie

5 P. Braido, Prevenire non reprimere. Il sistema educativo di don Bosco, LAS, Roma 2006, s. 324.

6 Por. Z. Dziubiński, Sport w perspektywie salezjańskiej, Akademia Wychowania Fizycznego Józefa Piłsudskiego, Salezjańska Organizacja Sportowa Rzeczypospolitej Polskiej, Warszawa 2014, s. 15.

7 Jan Paweł II, Ojciec i nauczyciel młodzieży. List Ojca świętego Jana Pawła II do księdza Egidio Vigano, Przełożonego Generalnego Towarzystwa Św. Franciszka Salezego w setną rocznicę śmierci św. Jana Bosko, Poliglotta Vaticana, Watykan 1988, s. 8. 
poprzez zabawę, a jednocześnie do solidnego zaangażowania się w poważne zadania i obowiązki w taki sposób, że żaden z tych dwóch elementów nie traci nic ze swej ważności i znaczenia. Sprawy poważne są przeżywane w klimacie radości, a zabawa angażuje w swej dynamice uczucia, zdolności i plany"8. Jego dynamiczna aktywność to naturalny sposób wyrażania siebie. Był „duszą” towarzystwa, organizatorem i przywódcą spotkań koleżeńskich.

O jego pierwszych poczynaniach, inicjatywach i formach aktywności sportowej można wyczytać z kart książki Wspomnienia Oratorium. Już w wieku dziesięciu lat tworzy pierwsze „oratorium” wioskowe9. Jego charakter zjednywał mu przyjaciół, dlatego był lubiany i podziwiany. Ponieważ uznawany był przez swoich kolegów za przyjaciela, w sytuacji sporu miał przyzwolenie, aby być sędzią i rozjemcą. Sam wykorzystywał te sytuacje, aby studiować i poznawać charaktery swoich rówieśników. Jego obecność nie ograniczała się tylko do gier i zabaw. Posiadając zdolności oratorskie przytaczał kolegom opowiadania zasłyszane na kazaniach lub na lekcjach katechizmu. W długie zimowe wieczory czytał im książki. Jak sam wspominał, spotkania te zawsze kończyły się odmówieniem Zdrowaś Maryjo i znakiem krzyża świętego. W miesiącach letnich organizował wyścigi, zabawy i gry dłuższe. Podczas takich spotkań dość często prezentował swoje kuglarskie umiejętności, które podpatrzył u wędrujących sztukmistrzów. Mając jedenaście lat, potrafił chodzić na linie i wykonywać salto mortale. Spotkania z rówieśnikami nie ograniczały się jedynie do strony rekreacyjnej. Janek Bosko proponował cząstkę różańca, jakąś modlitwę lub powtarzał niedzielne kazanie. W spotkaniach tych nie mogli uczestniczyć chłopcy, którzy klęli, prowadzili niewłaściwe rozmowy lub sprzeciwiali się wspólnej modlitwie ${ }^{10}$. We wspólnej zabawie i byciu razem, Janek Bosko widział doskonałą okazję, aby pozostawić grupie jakąś pożyteczną rzecz, która budowała ich życie religijne.

Innym przykładem potwierdzającym powyższą postawę Janka Bosko jest epizod ze sztukmistrzem w Chieri, gdzie Janek uczęszczał do szkoły. Wędrowny kuglarz odciągał ludzi od pójścia do kościoła. Janek, widząc to, podjął się ryzykownego zadania. Zwykły i niedoświadczony chłopiec rzucił wyzwanie profesjonaliście. Dzięki zdolnościom fizycznym wyszedł z próby zwycięsko. W tym samym Chieri Janek Bosko założył wśród kolegów „Towarzystwo We-

\footnotetext{
8 J. E. Vecchi, Pastorale e sport, w: Insieme ai giovani, Associazioni CIOFS - CNOS, CGS media, PGS - sport, TGS - turismo, Roma 1997, s. 75.

9 Por. G. Bosco, Memorie dell'Oratorio di s. Francesco di Sales, SDB, Roma 1992, s. 27.

10 Por. tamże, s. 40-43.
} 
sołości". Głównym jego celem było rzetelne i solidne wypełnianie obowiązków szkolnych i religijnych. Natomiast drugim celem było szerzenie radości. Jej źródłem była rekreacja, gry, zabawy, przechadzki ${ }^{11}$.

W 1841 r. kleryk Jan Bosko otrzymał święcenia kapłańskie. Zmienił się więc jego status. Jednak doświadczenia $\mathrm{z}$ lat dziecięcych i młodzieńczych w sposób naturalny pozostały nadal obecne w jego pracy. Po święceniach biskup Turynu wysłał go na dalsze studia z zakresu teologii pastoralnej. Zamieszkał więc w tzw. Konwikcie, gdzie dyrektorem był ks. Józef Cafasso, jego spowiednik, kierownik duchowy oraz sponsor jego działalności. Dzięki niemu, oprócz studiów, ks. Bosko podjął pracę w jednym z turyńskich więzień. Zdecydowana większość tam osadzonych, to ludzie bardzo młodzi. Doświadczenie pracy z nimi zapaliło w ks. Bosko ideę systemu prewencyjnego. Regularnie spotykał się również w niedzielę i święta z chłopcami miasta, prowadząc pracę oratoryjną. Wychowankowie ci, to chłopcy opuszczeni pod względem społecznym, kulturalnym, religijnym, a najbardziej moralnym. Ich wielka liczba to rezultat doby industrializacji Piemontu. Rozwój przemysłu z pewnością niwelował różnice pomiędzy Włochami a resztą Europy i tworzył nowe miejsca pracy, ale również był przyczyną nowych zjawisk, takich jak: wielkie migracje ludności do miast, powstanie nowej grupy społecznej, jaką był proletariat, pojawienie się dzieci ulicy, rozluźnienie więzów rodzinnych, co prowadziło do kryzysu rodziny ${ }^{12}$.

Ksiądz Jan Bosko całą uwagę skupił na opuszczonej i biednej młodzieży turyńskiej. W tradycyjnej pracy duszpasterskiej znajdował także miejsce na czynną rekreację, która stała się jednym z podstawowych czynników jego metody wychowawczej. Jako dobry obserwator i pedagog, ks. Bosko szybko zauważył i zrozumiał znaczenie gier i zabaw. Doskonale zdawał sobie sprawę, że boisko przyciąga bardziej niż kościół. Liczył się z tym, że wielu chłopców nie przyszłoby ponownie, gdyby nie gry i zabawa. Minister Spraw Wewnętrznych, Franciszek Crispi, obserwując pracę ks. Bosko z turyńską młodzieżą, napisał: „Doświadczenie mówi nam, że bardzo łatwo zdobyć chłopców poprzez boisko, urozmaicony czas rekreacji, muzykę, gimnastykę, skoki, deklamację poezji. Następnie poprzez szkoły wieczorowe, niedzielne i naukę katechizmu, ks. Bosko dawał chłopcom po-

11 Por. tamże, s. 57-58; P. Braido, L'esperienza pedagogica di don Bosco, dz. cyt., s. 144.

12 Por. P. Braido, Don Bosco prete dei giovani nel secolo delle libertá, LAS, Roma 2003, t. I, s. 33. 
karm duchowy, tak niezmiernie im potrzebny i ważny"13. Jego wychowankowie w większości pracowali bardzo ciężko cały tydzień. Do tego dochodziła nostalgia i brak więzów uczuciowych z najbliższymi. Czynna rekreacja była więc elementem bardzo użytecznym, pożądanym i akceptowanym przez chłopców. Ksiądz Bosko planował i organizował im czas wolny. Ponadto zawsze sam brał udział w grach i zabawach, zyskując sobie w ten sposób ich zaufanie. Należy jednak podkreślić, że celem tych spotkań była zawsze formacja religijna ${ }^{14}$.

Oratorium świąteczne powoli przeradzało się w zorganizowaną instytucję, jaką było oratorium na Valdocco. W nim była obecna kaplica, modlitwa, katechizm. Dla ks. Bosko oratorium oznaczało pewną "przestrzeń”, w której młody człowiek znajdował odpowiednie warunki do rozwoju całej osobowości. Oprócz wymiaru religijnego, była tam również możliwość spożytkowania wielkiej młodzieńczej energii we właściwy sposób. Temu służyła rekreacja, śpiew, orkiestra, gry, zabawy. Ksiądz Bosko chciał, aby tłem tego obszaru była radość, która naturalnie przyciąga młodego człowieka. Często powtarzał swoim wychowankom, że dobry chrześcijanin nie musi się wyrzekać radości. Temu zagadnieniu poświęcił fragment małego dziełka przeznaczonego dla nich. W Giovane provveduto (Młodzieniec zaopatrzony) pisał: „Istnieją dwa główne oszustwa, którymi zły duch chce odwieść młodzież od cnoty. Pierwszym jest wmówić im, że służyć Bogu to znaczy wieść życie smutne i dalekie od wszelkich rozrywek i przyjemności. Nie taka jest prawda, drodzy młodzi przyjaciele! Ja chcę was nauczyć takiego sposobu życia chrześcijańskiego, który czyni je radosnym i pełnym zadowolenia, pokazując wam, jakie są prawdziwe rozrywki i prawdziwe przyjemności tak, byście mogli powiedzieć za prorokiem Dawidem: służmy Panu w radości: servite Domino in laetitia. Taki jest właśnie cel tej książeczki, służyć Panu i być zawsze radosnym"15.

Według historyka Piotra Braido, oratorium na Valdocco reprezentowało pewien styl życia, którego konstytutywnym elementem była radość. Łączyła ona naukę, pracę, praktyki religijne i podwórko. Radość to cecha okresu młodzieńczego i istnieje zarazem wielkie zapotrzebowanie na nią ze

\footnotetext{
13 II Sistema Preventivo applicato negli Istituti di rieducazione. Pro memoria al Ministro Crispi, Torino 1878, s. 24.

14 Por. G. Bosco, Memorie dell'Oratorio di s. Francesco di Sales, dz. cyt., s. 124.

15 G. Bosco, Il giovane provveduto, w: P. Braido, Don Bosco educatore. Scritti e testimonianze. LAS, Roma 2003, s. 38.
} 
strony młodego człowieka. Jednak, aby była ona autentyczna, musi posiadać wymiar duchowy i religijny. Podstawą radości jest życie w przyjaźni z Bogiem i bliźnimi (częsta zachęta do sakramentu spowiedzi). Prawdziwa radość wewnętrzna w sposób naturalny i szybki staje się widoczna na zewnątrz. Dla ks. Bosko radość była synonimem świętości i „jedenastym przykazaniem" na Valdocco ${ }^{16}$. Praktyka pracy z młodzieżą potwierdza zasady wprowadzone przez ks. Bosko. Radość, która rozpiera serce wychowanka, wyzwala olbrzymią energię w nim tkwiącą, którą najłatwiej wyzwolić w czasie uprawiania sportu. Do podobnych wniosków doszedł również inny wielki pedagog Rzymu, św. Filip Nereusz, który mówił swoim wychowankom: „Jeśli jest tylko na to czas, biegajcie, skaczcie, bawcie się, używajcie życia, tylko nie grzeszcie"17.

Jednym z wychowanków ks. Bosko był Michał Magone. Był to chłopiec o bardzo żywym i dynamicznym temperamencie. Jak zauważył ks. Bosko, przy końcu rekreacji zazwyczaj wyglądał na mocno niezadowolonego. Natomiast wyskakiwał jak pocisk $\mathrm{z}$ armaty, gdy po skończonych pracach, zajęciach czy lekcjach biegł na boisko ${ }^{18}$. Nie wszyscy wychowankowie prezentowali podobne postawy. Jednak za radą ks. Bosko uczestniczyli w rekreacjach, próbując uczyć się pewnych umiejętności i czynnie włączyć się gry. Czym była dla ks. Bosko taka rekreacja? Fizycznie obecny, ks. Bosko wykorzystywał ją do nawiązania osobistego kontaktu z chłopcami. „Przy okazji” szeptał na ucho wychowankom spostrzeżenia i uwagi ich dotyczące. Zachęcał do lepszego wykonywania obowiązków, posłuszeństwa, punktualności, naprawy relacji $\mathrm{z}$ innymi. Bardzo często czas rekreacji poświęcał na spowiedź ${ }^{19}$.

Życie w oratorium, a w nim i rekreacja, nabierały szczególnego znaczenia w okresie świąt religijnych, państwowych czy innych ważnych okoliczności. Wyjątkowym czasem były dni zakończenia karnawału. Podczas ich trwania były obecne bardziej uroczyste Msze św., adoracje Najświętszego Sakramentu, śpiewy, modlitwy, konferencje na różne tematy. Ksiądz Bosko w tych dniach troszczył się również o lepszy stół. Podczas wolnego czasu pojawiały się loterie, teatr, muzyka, przechadzki. W życiu chłopców było więc obecne „sacrum” i „profanum”. Wydaje się, że te dwa

16 Por. P. Braido, Prevenire non reprimere. Il sistema educativo di don Bosco, LAS, Roma 2006, s. 325.

17 Tamże.

18 Por. P. Braido, Don Bosco prete dei giovani nel secolo delle libertá, dz. cyt., t. I, s. 334.

19 Por. G. Bosco, Memorie dell'Oratorio di s. Francesco di Sales, dz. cyt., s. 139. 
wymiary: obowiązku i przyjemności, pracy i odpoczynku, łaski i natury, były zaproponowane wychowankom w stopniu tak odpowiednim i wyważonym, że oratorium ciągle było dla nich miejscem pociągającym, do którego chętnie wracali ${ }^{20}$.

Ksiądz Bosko, baczny obserwator młodego człowieka, bazując na swoim doświadczeniu w pracy wychowawczej, wiedział, że rekreacja szeroko rozumiana jest czynnikiem przywracającym pewną równowagę w życiu psychicznym młodego człowieka. Dlatego uważał ją za nieodzowną w życiu oratoryjnym. Z tego też powodu, stała się ona przedmiotem jego refleksji, obserwacji, analizy, a później organizacji i kierowania nią. Ksiądz Bosko widział, że rekreacja wyzwala radość, entuzjazm i spontaniczność, a także wpływa na duchową równowagę. Ponadto relaksuje umysł, rozwija i wzmacnia ciało. Dlatego radził swoim wychowankom wybrać taką grę, w której czuliby się pewnie i dobrze. Zabawom tym jednak miała towarzyszyć dyscyplina osobista, przede wszystkim zrozumiana i zaakceptowana przez chłopca. Wspólnym zabawom muszą bowiem towarzyszyć pewne reguły i zasady, które należy przestrzegać. Oprócz wymienionych już walorów, sport kształtuje wartości dotyczące relacji z innymi, jak np.: umiejętność współpracy, szlachetność, uczciwość, przyjaźń, wspaniałomyślność, dobre wychowanie. Zdrowa rekreacja wpływa pozytywie na cały proces wychowawczy. Warto w tym miejscu przywołać wizytę pewnego dziennikarza, którą złożył księdzu Bosko na Valdocco. Dziennikarz był bardzo zaskoczony i zdumiony atmosferą, dyscypliną i porządkiem, jaki panował na oratoryjnym boisku. Spytał o to ks. Bosko, który mu odpowiedział: „My zamiast kar stosujemy asystencję i sport”21. Aktywna obecność wychowawcy zapobiega łamaniu prawa, czego konsekwencją jest brak kar. W innym miejscu ks. Bosko mówił: „Należy pozwolić na skoki, bieganie, hałasowanie do woli. Gimnastyka, muzyka, wycieczki są najbardziej skutecznymi środkami do utrzymania dyscypliny"22.

Dla ks. Bosko boisko, podwórko, rekreacja były miejscami, które umożliwiały mu poznanie wychowanków. Podczas gier i zabaw młody człowiek jest zazwyczaj otwarty, uśmiechnięty i zachowuje się spontanicznie. Wykorzystując te okoliczności, wychowawca może szepnąć na ucho coś

\footnotetext{
20 Por. P. Braido, Prevenire non reprimere. Il sistema educativo di don Bosco, dz. cyt., s. 326.

21 Por. J. Vecchi, Duszpasterstwo i sport, w: Z. Dziubiński, Sport w służbie młodzieży. Optyka chrześcijańska i salezjańska, Salezjańska Organizacja Sportowa Rzeczypospolitej Polskiej, Warszawa 2007, s. 42.

22 Tamże.
} 
bardzo szczególnego wychowankowi. To z kolei może doprowadzić chłopca do zastanowienia się nad swoją wadą. Ksiądz Bosko w rozmowie z salezjanami zwracał uwagę na postawę wychowawcy i wychowanka w szkole i na boisku. W szkole, niejako z obowiązku, nauczyciel zachowuje się bardzo formalnie i moralizuje. Natomiast na boisku wytwarza się szczególna atmosfera. Jeśli wychowanek słyszy nawet jakąś uwagę, to odczytuje słowa wychowawcy raczej w kluczu przyjaźni, a nie czystego formalizmu. Można więc zakładać, że słowa te szybciej trafią do jego serca. W 1884 r. ks. Bosko skierował do salezjanów tzw. List z Rzymu, który tradycja salezjańska uważa za jeden z najważniejszych dokumentów poświęconych wychowaniu. Autor poleca obserwować wychowanków nie tylko w kościele czy w szkole, ale mówi: „Obserwuj młodzież na rekreacji” ${ }^{23}$.

„Ksiądz Bosko powraca”, to słowa tradycyjnej pieśni Rodziny Salezjańskiej. Jej słowa wyrażają pragnienie powrotu ks. Bosko i powrotu do jego metody wychowawczej po to, aby być wychowawcami wrażliwymi na potrzeby współczesnej młodzieży. Jesteśmy świadkami jednoczenia się Europy, chociaż zauważa się, że proces ten napotyka na różne trudności Coraz bardziej znane są mechanizmy rządzące życiem społecznym, politycznym i ekonomicznym globalizowanego świata. Globalizacja jako zjawisko sama w sobie nie jest ani dobra ani zła. Za nią stoi zawsze konkretny człowiek. On może kreować mechanizmy, które mogą ułatwić lub utrudnić rozwój i wychowanie młodego pokolenia. Świat ludzi młodych jest bardzo wrażliwy na procesy, które rządzą ludzkim życiem. W tym kontekście, salezjańska wizja sportu może stanowić jakąś ofertę dla współczesnego wychowania. Salezjańska propozycja sportu przekracza granice aktywności fizycznej. Sport w rozumieniu ks. Bosko nie jest nastawiony na zdobywanie medali, ale na integralny rozwój wychowanka. Sport sam w sobie nie wpłynie na wzrost młodego człowieka, ale może wpłynąć na sposób podejścia do niego. Dzięki współpracy z odpowiedzialnym i mądrym wychowawcą, młody człowiek może widzieć stronę jakościową sportu. Wychowawca w duchu ks. Jana Bosko powinien rozumieć różnicę pomiędzy uprawianiem sportu a wychowaniem przez sport oraz umieć wykorzystywać aktywność fizyczną wychowanka w procesie wychowania ${ }^{24}$.

Jedną z podstawowych reguł obowiązujących w sporcie jest zasada fair play. Od najdawniejszych epok osoby uprawiające sport próbowały zasadę

${ }^{23}$ Por. G. Bosco, Lettera 1884, Tipografia Don Bosco, Roma 1984, s. 29.

${ }^{24}$ Por. Z. Dziubiński, Sport w perspektywie salezjańskiej, dz. cyt., s. 41. 
tę wcielać w praktykę. W swojej istocie nawiązuje ona do szeregu cnót chrześcijańskich oraz do etosu średniowiecznego wychowania rycerskiego. Ideą wiodącą tej zasady jest szlachetność całego życia osoby. Dotyczy ona każdego człowieka. Dlatego staje się ponadczasowa, uniwersalna i także ponadpolityczna. Zadaniem wychowawcy jest ukazanie tej zasady młodzieży jako atrakcyjnej i właściwej postawy wobec drugiej osoby. Postawy sportowców oddziaływają bardzo sugestywnie na młodego człowieka, który traktuje ich jako idoli i naśladuje ich postawy. Bardzo często u sportowców zauważa się nierespektowanie powyższej zasady. Zachodzi to w sytuacjach, kiedy brakuje między innymi motywacji religijnej. Rywalizacja sportowa nie stoi w sprzeczności z tą regułą, ale obie znajdują dopełnienie w normach etyki chrześcijańskiej. Ta ostatnia jest źródłem postaw, których nie da się określić i zdefiniować przy pomocy paragrafów prawa. Bazując na specjalistycznej prasie sportowej, można odnieść wrażenie, że zasada fair play staje się coraz mniej popularna. Badacze tematu upatrują przyczynę tego problemu w pragnieniu zwycięstwa za wszelką cenę. Takie podejście z pewnością niszczy zasady etyczne i pozbawia sportowców autentycznej radości płynącej z uprawiania sportu ${ }^{25}$. Zachowanie takie jest niezgodne $\mathrm{z}$ testamentem Pierra de Coubertina, ojca nowego olimpizmu ${ }^{26}$.

Celem uprawiania sportu jest zwycięstwo. Jednak jest to jedno z najtrudniejszych zadań, jakie stoi przed współczesnym pedagogiem. Umiejętność odpowiedniego przyjęcia zwycięstwa to proces, który dokonuje się cały czas w młodym człowieku. Wychowywanie do zwycięstwa jest nie mniej ważne od przygotowania do porażki. Świętowanie zwycięstwa przychodzi dużo łatwiej niż porażka. Jednak, aby spełniało ono swój charakter wychowawczy, sportowiec musi pamiętać o szeregu czynników, które przyczyniły się do niego. Odniesione zwycięstwo to nie tylko wysiłek sportowca, ale praca całej drużyny, również zawodników rezerwowych, lekarzy $\mathrm{i}$ innych służb. Drużyna przegrana ceni sobie moment, w którym zwycięzcy podchodzą do nich, dziękując im za czas spędzony razem, możliwość spotkania i wypowiadają kilka słów pocieszenia.

Z punktu widzenia dobrego wychowania, rzeczą bardzo pozytywną byłoby zaproszenie strony przegranej do wspólnego świętowania. Gest

25 Por. Jan Paweł II, Przemówienie na Stadionie Olimpijskim w Rzymie w dniu 12 kwietnia 1984 r. podczas uroczystości „Jubileuszu Sportowców”, „Magazyn Olimpijski” 4(2000), s. 43.

26 Por. J. Niewęgłowski, Wychowawcza funkcja sportu w nauczaniu Jana Pawła II, w: Kultura fizyczna a kultura masowa, red. Z. Dziubiński, Akademia Wychowania Fizycznego Józefa Piłsudskiego, Salezjańska Organizacja Sportowa Rzeczypospolitej Polskiej, Warszawa 2011, s. 356. 
ten pomaga łatwiej zaakceptować przegraną, uświadamia także, że w chwili porażki przegrani nie zostają sami. Niejednokrotnie zaproszenie to jest odrzucane. Jest to rezultat również niedojrzałej postawy drużyny pokonanej. Podczas uprawiania sportu rolą pedagoga jest przypominać, że ludzką rzeczą jest wygrywać i ludzką rzeczą jest przegrywać. W młodym człowieku należy kształtować te dwie postawy ${ }^{27}$. Zdolność przyjęcia lub odrzucenia przegranej świadczy o dojrzałości emocjonalnej osoby. Każdy człowiek doświadcza smaku przegranej, frustracji i uczucia zazdrości. Młodego człowieka należy długo przygotowywać do przyjęcia przegranej. Akceptacja porażki wymaga od osoby właściwie ukształtowanej hierarchii wartości. Jej posiadanie ułatwi, w sposób racjonalny i spokojny, zbadanie przyczyn niepowodzenia, a nie szukanie za wszelką cenę kozła ofiarnego we własnej drużynie.

Przegrana może również spełnić pozytywną funkcję. Pozwala ona odkryć słabe strony drużyny, brak formy, niewłaściwe przygotowanie fizyczne czy brak taktyki gry. Niekiedy przegranej towarzyszy gniew, apatia, załamanie, rozpacz. Może to prowadzić zawodnika do głębokiej frustracji. Porażka powinna zawodnikowi uzmysłowić, że sport nie może być traktowany jako wyczyn czysto techniczny lub nastawiony na zwycięstwo. Ponadto przegrana powinna przypominać, że zwycięzcy nie są moimi wrogami, ale również są ludźmi. Po prostu, podczas gry okazali większe umiejętności ${ }^{28}$.

W czasach dzisiejszych z łatwością zauważa się, że bardzo wiele inicjatyw sportowych organizowanych jest dla celów komercyjnych. Dla wielu osób imprezy sportowe są tylko afiszem, za którymi stoją korzyści finansowe i interesy różnego rodzaju. W celu osiągnięcia tych korzyści sportowcy często korzystają z metod niezgodnych z zasadą fair play. Wychowanie więc powinno zwracać uwagę przyszłych sportowców na sytuacje, w których można wszystko kupić i wszystko jest handlem. Człowiek sportu musi widzieć wartość, jaką jest bezinteresowność. Tylko w takiej optyce sport nie będzie miejscem, gdzie będą się liczyły tylko wyniki, rewanże i medale, ale będzie miejscem prawdziwej zabawy, święta i twórczości. Bezinteresowność ułatwi również wypracować postawę pozbawioną agresji i przemocy ${ }^{29}$.

27 Por. A. Pawłucki, Sportowiec, pseudo-sportowiec, anty-sportowiec. Dlaczego czyn sportowy jest moralnie dobry?, w: Kultura fizyczna a kultura masowa, dz. cyt., s. 295.

28 Por. tamże, s. 300.

29 Por. M. Barlak, Ponadczasowy charakter pedagogii św. Jana Bosko w perspektywie trzeciego tysiąclecia, w: Salezjanie a sport, red. Z. Dziubiński, Salezjańska Organizacja Sportowa Rzeczypospolitej Polskiej, Warszawa 1998, s. 125. 
Ksiądz Jan Bosko, tworząc system wychowawczy, który tradycja nazwała prewencyjnym, zaplanował w nim miejsce dla sportu. Jako baczny obserwator życia społecznego, a szczególnie życia młodego człowieka w czasach wielkiego kryzysu przejawiającego się w postaci ubóstwa materialnego, duchowego, intelektualnego, brutalizacji relacji międzyludzkich, kradzieży, bandytyzmu, prostytucji i innych, uznał że jest on ważny w pracy z dziećmi i młodzieżą jako środek, który może odegrać ważną rolę w procesie wychowania. Szeroko rozumiana rekreacja jako aktywność sportowa jest wartością autoteliczną i instrumentalną. Z jednej strony, zaspokaja naturalne potrzeby związane $\mathrm{z}$ rozwojem motoryki, $\mathrm{z}$ drugiej, służy realizacji wartości społecznych, zdrowotnych, kulturowych, moralnych, intelektualnych. W takiej perspektywie sport nie jest aktywnością nastawioną na widowisko, pieniądze, medialność, jak to zauważa się w przypadku sportu profesjonalnego, ale podporządkowany jest holistycznemu rozwojowi młodego człowieka i jego dobru. 


\section{Ks. Henryk Stawniak SDB}

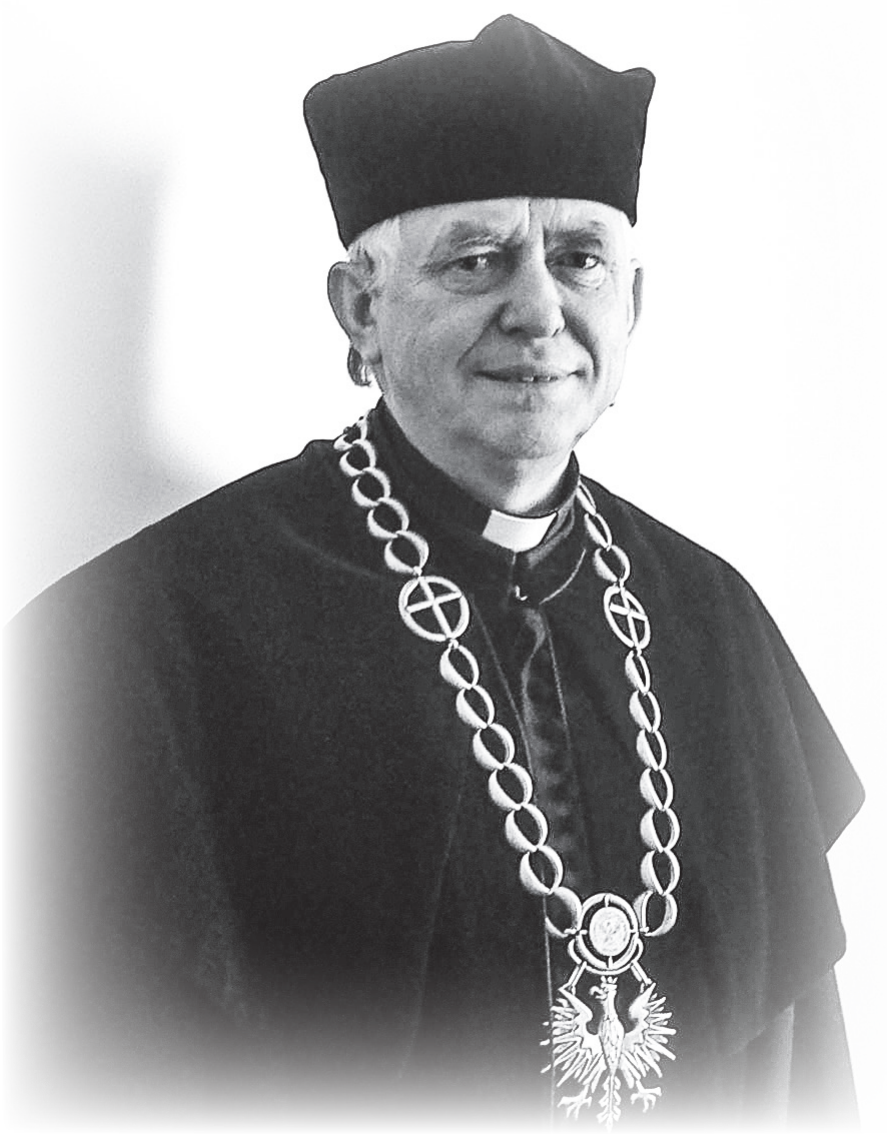

prof. zw. dr hab.,

dziekan Wydziału Prawa Kanonicznego UKSW w Warszawie, kierownik Katedry Kościelnego Prawa Małżeńskiego i Rodzinnego na tymże Wydziale, zastępca redaktora naczelnego kwartalnika „Ius Matrimoniale”, członek Rady Naukowej Konferencji Episkopatu Polski, autor ponad 150 opracowań, głownie z prawa małżeńskiego. 


\section{Ks. Henryk Stawniak SDB \\ Małżeństwo w nauczaniu papieża Franciszka - aspekt kanoniczny}

Nauczanie papieża Franciszka o małżeństwie, jak się wydaje, domaga się przedstawienia go w kontekście rozumienia nierozerwalności małżeństwa w nauczaniu Jana Pawła II, wystąpienia kardynała Waltera Kaspera na Konsystorzu Kardynałów w 2014 roku, motu proprio papieża Franciszka Mitis Iudex Dominus Iesus z 2015 roku, Relacji końcowej Synodu z 2015 roku oraz adhortacji apostolskiej Amoris laetitia. Wymienione sprawy i dokumenty będą wyznaczać i stanowić strukturę ujęcia tematu. Nauczanie papieskie o małżeństwie zostanie ograniczone do aspektu kanonicznego, podkreślając i uwydatniając trudną problematykę związków «nieregularnych» w perspektywie włączenia ich we wspólnotę Kościoła.

\section{Nierozerwalność małżeństwa w nauczaniu Jana Pawła II}

W Kościele katolickim mówi się o nierozerwalności, ale też o różnych jej stopniach. Bezwzględny charakter ma nierozerwalność w przypadku małżeństwa dopełnionego, niższy stopień nierozerwalności ma małżeństwo zawarte przez osoby ochrzczone oraz osobę ochrzczoną i nieochrzczoną, jeśli nie jest dopełnione. Zaś najniższy stopień nierozerwalności ma małżeństwo zawarte przez osoby nieochrzczone, bo chociażby zostało dopełnione może być rozwiązane na mocy przywileju wiary ${ }^{1}$.

Nierozerwalność małżeństwa, w nauczaniu Soboru Watykańskiego II i konsekwentnie w przepowiadaniu kolejnych papieży, jawi się jako wymóg antropologiczny wpisany w istotę małżeństwa. Papież Jan Paweł II

\footnotetext{
1 Por. Kodeks Prawa Kanonicznego [dalej: KPK], kan. 1141-1143, 1148-1150; także T. Pawluk, Przesłanki nierozerwalności małżeństwa, „Prawo Kanoniczne” 36(1983)1-2, s. 221-222; S. Świaczny, Wykonywanie władzy przez Kościół nad węzłem nieochrzczonych. Związki aktualnej normy w doktrynie na przestrzeni pierwszego tysiąclecia, „Prawo Kanoniczne” 43(2000)3-4, s. 253-272.
} 
dobitnie podkreślał myśl, że nierozerwalność jest «wpisana» w istotę małżeństwa i odnosi się do wszystkich zawierających małżeństwo w każdym miejscu i czasie. Kanon 1056 wyraźnie dopowiada, że nierozerwalność jest istotnym przymiotem małżeństwa. Fałszywy jest zatem pogląd, jakby nierozerwalne małżeństwo miało odnosić się do wierzących jako pewien ideał życia chrześcijańskiego. Tak samo niewłaściwa jest opinia, że nierozerwalność jest ograniczeniem wolności partnerów, a zarazem ciężarem, który czasem może okazać się nie do zniesienia. W takim ujęciu nierozerwalność traktowana jest jako prawo zewnętrzne w stosunku do małżeństwa, jako norma narzucona wbrew oczekiwaniom realizacji siebie jako osoby. Stąd ważne jest obiektywne przedstawienie tej cechy małżeństwa $\mathrm{i}$ istnieje potrzeba - jak zauważa papież Jan Paweł II w słynnym przemówieniu do Roty Rzymskiej z roku 2002 - pozytywnego ujęcia nierozerwalności, nie jako ciężaru, ale jako dobra dla małżonków, dla dzieci, dla Kościoła i dla całej ludzkości²

Pozytywnym ujęciem nierozerwalności, a zarazem argumentem na jej rzecz, jest samo pojęcie małżeństwa rozumianego jako „głęboka wspólnota życia i miłości” i zgoda stron jako całkowite oddanie się dwóch osób. Nietrwałość byłaby dowodem połowiczności, bo jeśli człowiek zastrzega coś dla siebie lub rezerwuje sobie możliwość zmiany decyzji w przyszłości, już przez to samo nie oddaje się całkowicie ${ }^{3}$. Podobnie ma się sprawa z pojęciem miłości małżeńskiej, która jest całkowitym darem z siebie, to niczym nie uwarunkowane zaangażowanie wyrastające poza czas, a które przeżywane w czasie, wypełnia z konieczności cały czas ${ }^{4}$. Konstytucja Gaudium et

2 Por. Jan Paweł II, L'allocuzione alla Rota Romana del 2002, AAS 94(2002)2, s. 341; W. Góralski, Małżeństwo i rodzina instytucjami prawa naturalnego w świetle przemówień papieża Jana Pawła II do Roty Rzymskiej, w: Matrimonium spes mundi. Małżeństwo i rodzina w prawie kanonicznym, polskim i międzynarodowym. Księga pamiątkowa dedykowana ks. prof. Ryszardowi Sztychmilerowi, red. T. Płoski, J. Krzywkowska, Wydawnictwo Uniwersytetu Warmińsko-Mazurskiego w Olsztynie, Olsztyn 2008, s. 102-104.

3 Por. Sobór Watykański II, Konstytucja duszpasterska o Kościele w świecie współczesnym "Gaudium et spes" (7 grudnia 1965) [dalej: GS], nr 48; Jan Paweł II, Adhortacja apostolska „Familiaris consortio” (22 listopada 1981) [dalej: FC], nr 11; KPK, kan. 1057 §2; H. Stawniak, Jedność i nierozerwalność małżeństwa, „Prawo Kanoniczne” 34(1991)1-2, s.111.

${ }^{4}$ Por. F. Varillon, Zarys doktryny katolickiej, tłum. E. Krasnowolska, Wydawnictwo PAX, Warszawa 1972, s. 553; J. Grześkowiak, Sakramentalność małżeństwa w „Familiaris consortio”, w: Małżeństwo i rodzina w świetle nauki Kościoła i współczesnej teologii, red. L. Szafrański, Towarzystwo Naukowe Katolickiego Uniwersytetu Lubelskiego, Lublin 1985, s. 93-94. 
spes $^{5}$ wiąże bezpośrednio nierozerwalność z miłością. Innym pozytywnym wymiarem nierozerwalności jest wspomniane już dobro małżonków (kan. $1055 \$ 1 \mathrm{KPK}$ ), czyli wzajemne obdarowanie się sobą przez małżonków i z uwagi na kolejny cel, jakim jest zrodzenie i wychowanie potomstwa. Tego naturalnego celu rodzice nie zrealizują, jeśli nie założy się, że małżeństwo będzie trwałe. Zrodzone potomstwo trzeba tak wychować, aby było zdolne do samodzielnego i pełnego życia w społeczeństwie, a to wymaga czasu. Wypada do powyższych racji dołączyć także dobro poszczególnych społeczeństw i całej ludzkości oraz dobro Kościoła ${ }^{6}$.

$\mathrm{W}$ pozytywnym ujęciu nierozerwalności, zwłaszcza w przeciwieństwie do rozwodu, należy odnieść się przede wszystkim do argumentów zawartych w Objawieniu. Jezus radykalnie odrzucał ówczesne poglądy o przyczynach, które mogłyby upoważniać do rozwodu, twierdząc: „przez wzgląd na zatwardziałość serc waszych pozwolił wam Mojżesz oddalać wasze żony, lecz od początku tak nie było" (Mt 19,8). Według nauczania Jezusa, to Bóg złączył w węźle małżeńskim mężczyznę i kobietę. Oczywiście, taki związek powstaje za dobrowolnym przyzwoleniem obojga partnerów, ale ta ludzka zgoda opiera się na planie, który jest Boski. Innymi słowy, niezbędnym kluczem do rozumienia istotnych cech małżeństwa [jedności i nierozerwalności] jest naturalny wymiar zwiąku, a konkretniej natura człowieka ukształtowana przez Boga. W małżeństwie chrześcijańskim ich ostateczne umocnienie przez sakrament opiera się, jak uwydatniono wyżej, na fundamencie prawa naturalnego, bez którego byłoby niezrozumiałe same dzieło zbawcze oraz dokonane raz na zawsze przez Chrystusa wyniesienie rzeczywistości małżeństwa ${ }^{7}$. W tym kontekście słuszne jest stwierdzenie, że niezrozumienie nierozerwalnego charakteru małżeństwa oznacza niezrozumienie jego istoty.

Człowiek jako istota wolna może odrzucić plan Stwórcy i zbuntować się przeciw planowi miłości i wówczas pojawia się owa „zatwardziałość serca”. $\mathrm{Na}$ te sytuacje należy odpowiadać z pokorną odwagą wiary - poucza papieskie przesłanie - wiary, która wspomaga i umacnia sam rozum, aby mógł prowadzić

\footnotetext{
${ }^{5}$ GS 50: „Małżeństwo nie zostało jednak ustanowione jedynie w celu zrodzenia dzieci, bowiem nierozerwalny charakter przymierza pomiędzy osobami i dobro potomstwa wymagają, aby również wzajemna miłość małżonków, okazywana we właściwym porządku, rozwijała się i dojrzewała. Dlatego, choćby brakowało tak często upragnionego potomstwa, małżeństwo trwa jako związek i wspólnota całego życia, zachowując znaczenie i nierozerwalność”; por. także Katechizm Kościoła Katolickiego, Pallottinum, Poznań 1994 [dalej: KKK], nr 1644.

${ }^{6}$ Por. szerzej H. Stawniak, Jedność..., art. cyt., s.112-113.

7 Por. Jan Paweł II, L'allocuzione alla Rota Romana del 2002, AAS 94, (2002)3, s. 341.
} 
dialog z wszystkimi w dążeniu do prawdziwego dobra osoby ludzkiej i społeczeństwa. Traktowanie nierozerwalności nie jako prawnej normy naturalnej, ale jako zwykłego ideału zaprzecza nieodwołalnej woli Chrystusa, który absolutnie odrzucił rozwód, ponieważ „od początku tak nie było” (Mt. 19,8). Powyższe wywody można sprowadzić do syntetycznego ujęcia, że w naturę małżeństwa jest wpisana jego nierozerwalność, dlatego też normy kanoniczne i cywilne winny ten fakt uwzględniać, jeśli chcą być wierne cycerońskiej regule stanowienia prawa: „Z wewnętrznej natury człowieka należy czerpać przepisy prawa”.

\section{Tezy kard. Waltera Kaspera wyrażone na Konsystorzu w 2014 roku}

To papież Franciszek zdecydował o tym, że Kardynał Kasper miał wykład na temat spraw nurtujących Kościół. Na Konsystorzu Kardynałów w dniu 20.02.2014 roku, w kontekście wątpliwości o możliwość dopuszczania do Komunii świętej osób rozwiedzionych i żyjących w nowych związkach, postawił Kasper ważkie pytania: w jaki sposób Kościół w swoich działaniach duszpasterskich wspomnianych osób może odwołać się do nierozerwalnego dwumianu wierności nauce i miłosierdzia Bożego? Czy w obecnej sytuacji nie jest możliwy dalszy rozwój, który nie znosiłby wiążącej tradycji, ale uwypukliłby i pogłębił nowsze tradycje?"

Te dość ogólne pytania kard. Waltera Kaspera wynikały z przekonania, że wobec cierpienia wielu rozwiedzionych potrzebna jest zmiana paradygmatu Kościoła co do instytucji małżeństwa. Przy czym Autor uznawał, że nierozerwalności małżeństwa sakramentalnego nie można porzucić i odwołać się do powierzchownego i taniego rozumienia miłosierdzia. Miłosierdzie idzie $\mathrm{w}$ parze $\mathrm{z}$ wiernością. $\mathrm{Z}$ powodu miłosiernej wierności Boga nie ma jednak takiej ludzkiej sytuacji, zdaniem Kardynała, która byłaby całkiem bez wyjścia i odarta z nadziei. Jakkolwiek nisko upada człowiek, nie spada niżej niż sięga Boże miłosierdzie ${ }^{10}$. Purpurat był przekonany, że nie może istnieć ogólne rozwiązanie dla wszystkich przypadków, ale jest wąska ścieżka dla mniejszej zapewne części osób rozwiedzionych szczerze zainteresowanych sakramentami. Ta ścieżka ze strony Kościoła zakłada i wymaga discretio, rozeznania duchowego, roztropności i mądrości duszpa-

\footnotetext{
8 „Ex intima hominis natura haurienda est iuris disciplina”. Cicerone, De Legibus, II.

9 Por. W. Kasper, O udzielaniu komunii dla osób rozwiedzionych, „Tygodnik Powszechny” z 25.03.2014 r., s. 12-13.

10 Por. tamże.
} 
sterskiej. Discretio nie jest łatwym kompromisem między skrajnościami rygoryzmu i permisywizmu, lecz, tak jak każda cnota, doskonałością przekraczającą zdrową drogą środka i właściwej miary ${ }^{11}$. W tym kontekście nadto kard. Kasper sformułował warunki, których spełnienie upoważniałoby do korzystania z sakramentu pokuty i pojednania oraz Komunii św. po odbyciu odpowiedniej pokuty. Oto one: 1 . okazanie skruchy z powodu rozpadu małżeństwa; 2 . niemożność powrotu do małżeństwa; 3. niemożność rezygnacji - bez zaciągania nowej winy - z nowego związku; 4. rozwiedziona osoba stara się w nowym związku żyć wiarą i wychować w niej dzieci; 5. pragnie sakramentów jako źródła siły w tej sytuacji ${ }^{12}$.

Polemizując z niektórymi postulatami i warunkami pokuty przedstawionymi przez kard. Kaspera, prof. Wojciech Góralski zauważał, że „nawet najsurowsza pokuta i skrupulatne spełnienie owych pięciu warunków na nic się nie zda, gdy u kratek konfesjonału zabraknie mocnego postanowienia poprawy. A przecież osoby te pozostają w bezpośredniej okazji do grzechu, którego się nie wyrzekają: jak więc mogą otrzymać rozgrzeszenie?". Zatem, zdaniem uczonego, konieczny jest szósty warunek, zawarty w Familiaris consortio $\mathrm{nr} 84$, szczerej gotowości na formę życia we wstrzemięźliwości, czyli powstrzymania się od aktów, które przysługują jedynie małżonkom. Kard. Kasper na pewno znał wymagania adhortacji apostolskiej Jana Pawła II z 1981 roku, ale zdaje się, że ten warunek wstrzemięźliwości od aktów celowo pomijał, by otwierać drogę do dalszych dyskusji. Pomijał także naukę Jana Pawła II o tym, że istotny przymiot małżeństwa, jakim jest nierozerwalność, jest wpisany w naturę każdego małżeństwa.

Ciekawym wątkiem w dyskusji wokół nierozerwalności małżeństwa i Komunii św. przytoczonym przez kard. Kaspera była wskazówka z roku 1994 Kongregacji Nauki Wiary ${ }^{13}$, kiedy orzekła (a papież Benedykt XVI podtrzymał to podczas światowego spotkania rodzin $\mathrm{w}$ Mediolanie w 2012 r.), że osoby rozwiedzione w ponownych związkach nie mogą otrzymać Komunii sakramentalnej, ale mogą otrzymać tę duchową ${ }^{14}$. Oto fragment

\footnotetext{
11 Por. tamże, s. 16.

12 Por. tamże, s. 15; W. Góralski, O właściwe rozumienie nierozerwalności małżeństwa, „Niedziela" nr 14, z 6.04.2014 r., s. 24-25.

13 Por. Kongregacja Nauki Wiary, List do biskupów Kościoła katolickiego na temat przyjmowania Komunii świętej przez wiernych rozwiedzionych i żyjących w nowych związkach „Annus Internationalis Familiae", w: W trosce o pełnię wiary. Dokumenty Kongregacji Nauki Wiary 1966-1994, Biblos, Tarnów 1995, s. 410-414.

14 Por. tamże, s. 412.
} 
dokumentu Kongregacji Nauki Wiary z 1994 roku, na który powołuje się Kardynał: „[...] konieczne jest pouczenie zainteresowanych wiernych, że ich udział w życiu Kościoła nie ogranicza się wyłącznie do kwestii przyjmowania Eucharystii. Należy pomagać wiernym w głębszym zrozumieniu wartości udziału w eucharystycznej ofierze Chrystusa, komunii duchowej [podkr. H. S.], modlitwy, medytacji słowa Bożego, dzieł miłosierdzia i sprawiedliwości”. W rzeczy samej ten, komu udzielona zostaje komunia duchowa, staje się jednością z Chrystusem; czy to możliwe, żeby zarazem łamał przykazanie Chrystusa? Czy, odsyłając niektórych na drogę zbawienia pozasakramentalnego, nie podajemy w wątpliwość fundamentalnej struktury sakramentalnej Kościoła? Do czego zatem służy Kościół i jego sakramenty? Czy nie płacimy zbyt wysokiej ceny odpowiedzią na to pytanie ${ }^{15}$ ? Cytowany Purpurat nie daje odpowiedzi na te pytania, wskazuje drogę pokuty, łez pokuty, jako możliwe rozwiązanie. Niewątpliwie tezy kard. Kaspera miały wpływ na atmosferę wokół Synodu i jego przebieg w 2014 roku oraz na samego papieża.

\section{Motu proprio papieża Franciszka Mitis ludex Dominus lesus [MIDI]}

Sama nazwa dokumentu Mitis Iudex Dominus Iesus ${ }^{16}$ - Pan Jezus łagodnym Sędzią - jak zauważa Jan Dyduch ${ }^{17}$ - rzutuje na program i treść dokumentu papieża Franciszka z dnia 15.08.2015 r., promulgowanego 8.09.2015 r., a wchodzącego w życie 8.12.2015 r.Znamienne jest to, że dokument ukazał się jeszcze przed zakończeniem Synodu w październiku 2015 roku. To znaczy, że papież chciał wprowadzić zmiany w prawie procesowym niezależnie od tego, jaki kształt przybiorą postulaty końcowe synodu. Dokument ten na nowo reguluje proces kanoniczny o stwierdzenie nieważności małżeństwa, który winien być włączony w duszpasterską działalność Kościoła. W żaden sposób nie została naruszona bezwzględna nierozerwalność ważnie zawartego i dopełnionego małżeństwa oraz zasada, że małżeństwo cieszy się przychylnością prawa (kan. 1060 KPK). W tym kontekście papież Franciszek stwierdził: „[...] postanowiłem niniejszym listem opublikować przepisy, które nie mają

15 Por. W. Kasper, O udzielaniu komunii..., art. cyt., s. 14.

16 Papież Franciszek, List apostolski motu proprio „Mitis ludex Dominus lesus”, reformujący kanony Kodeksu Prawa Kanonicznego dotyczące spraw o orzeczenie nieważności małżeństwa [dalej: MIDI], tekst łacińsko-polski, Biblios, Tarnów 2015, s. 6-45.

17 Por. J. Dyduch, Praembuła, w: Praktyczny komentarz do listu apostolskiego motu proprio Mitis ludex Dominus lesus papieża Franciszka, red. P. Skonieczny, Wydawnictwo Diecezji Tarnowskiej Biblos, Tarnów 2015, s. 30-39. 
na celu promowania nieważności małżeństwa, ale przyspieszenie procesów, jak również ich uproszczenie w taki sposób, aby wierni, którzy czekają na wyjaśnienie swojej sytuacji, nie byli zbyt długo dręczeni przez mroki wątpliwości z powodu opóźnień w wydaniu wyroku"18. Zmiany norm procesowych dotyczą zarówno procedury, jak i składu osobowego sądu. Mają one skrócić, uprościć i ułatwić dotychczasowy proces, nie naruszając konstytutywnych zasad małżeństwa. Ze względu na charakter przedłożenia, podam zmiany tylko sumarycznie. I tak, zmianie uległa właściwość sądu mogącego rozpoznawać sprawy o nieważność. Oprócz sądów właściwych ze względu na zawarcie małżeństwa i zamieszkania strony pozwanej, szersze kompetencje otrzymują sądy zamieszkania strony powodowej i miejsca zbierania większości dowodów (por. kan. 1672 CIC/MIDI). Bardzo istotną zmianą jest zniesienie normy o ścisłym obowiązku wymogu dwuinstancyjności procesu, czyli abrogowany został obowiązek potwierdzenia pozytywnego wyroku w II instancji ${ }^{19}$. Sąd, który wyda wyrok, nie będzie przesyłał akt do trybunału drugiej instancji, ale staje się on wykonalny, jeżeli żadna ze stron lub obrońca węzła czy rzecznik sprawiedliwości nie wniesie apelacji do wyższej instancji ${ }^{20}$.

MIDI pozwala na większy udział świeckich w procesie, w trójosobowym kolegium sędziowskim może bowiem być dwóch świeckich (por. kan. $1673 \$ 3 \mathrm{CIC} / \mathrm{MIDI}$ ), któremu przewodniczy duchowny. Przed reformą mogła być z konieczności tylko jedna osoba świecka w kolegium sędziowskim. Zasadniczo sprawy o stwierdzenie nieważności małżeństwa są rozstrzygane przez trybunał kolegialny, chociaż MIDI dopuszcza możliwość ustanowienia trybunału kolegialnego, w którym biskup moderator może powierzyć sprawy jednemu sędziemu będącemu duchownym, który winien dobrać sobie dwóch asesorów zatwierdzonych przez biskupa (por. $1673 \$ 4$ CIC/MIDI). Natomiast trybunał II instancji winien być zawsze kolegialny do ważności wyrokowania (por. $1673 \$ 5$ CIC/MIDI).

Całkowicie nowy na gruncie prawa procesowego i charakteryzujący się znacznie prostszą i szybszą procedurą jest proces skrócony przed bisku-

\footnotetext{
18 MIDI, preambuła.

19 Por. J. Lobell, Alcune questioni comuni ai tre proccessi per la dicharazione di nullitá del matrimonio previsti dal m.p. „Mitis ludex, s. 16, <http://www.consociatio.org/repository/Moneta_Lumsa.pdf>, (data dostępu: 15.04.2015).

20 Por. kan. 1679 i 1680 CIC/MIDI; W. Góralski, Motu proprio papieża Franciszka Mitis ludex Dominus lesus. Prezentacja dokumentu, „lus Matrimoniale” 26(2015)3, s. 11-12.
} 
pem według art. 5 kan. 1683-1687 CIC/MIDI ${ }^{21}$. Jest to proces prowadzony przed biskupem, czyli jest wyjątkiem od zasady kolegialności trybunału. Wolą najwyższego prawodawcy jest, aby biskup diecezjalny osobiście zaangażował się w kierowanie sądem w procesie skróconym, w którym wydaje wyrok jako pasterz. Ma on być gwarantem katolickiej jedności z Piotrem w wierze i dyscyplinie. Papież Franciszek, tak stanowiąc o procesie skróconym, oparł się na nauczaniu Vaticanum II ${ }^{22}$, w którym wyraźnie stwierdza się, że biskup osobiście w swoim Kościele, w którym został ustanowiony pasterzem i głową, tym samym jest sędzią wobec wiernych, którzy zostali mu powierzeni (por. preambuła MIDI III). Postępowanie skrócone nie może zagrażać zasadzie nierozerwalności małżeństwa i skarga o nieważność małżeństwa winna być poparta szczególnie oczywistymi argumentami. Sam prawodawca $\mathrm{w}$ art. 14 MIDI daje przykłady okoliczności dopuszczających rozpoznanie sprawy o nieważność małżeństwa w procesie skróconym przed biskupem. Są to: taki brak wiary, który może prowadzić do symulacji konsensu lub błędu determinującego wolę, krótki czas pożycia małżeńskiego, aborcję dokonaną dla uniknięcia zrodzenia potomstwa, pozostawanie w relacji pozamałżeńskiej w czasie zawierania małżeństwa lub wkrótce po ślubie, podstępne zatajenia bezpłodności, poważnej choroby zakaźnej, potomstwo z wcześniejszego związku lub pozbawienia wolności, zawarcie małżeństwa z przyczyny całkowicie obcej życiu małżeńskiemu lub wynikającej z nieoczekiwanej ciąży kobiety, użycie przemocy fizycznej w celu wymuszenia konsensu, brak używania rozumu potwierdzony dokumentacją medyczną itd. Należy zauważyć najpierw, że katalog okoliczności nie jest zamknięty, a następnie że wymienione okoliczności nie stanowią tytułu nieważności, ale każda z nich musi być rozpatrywana w kontekście konkretnego tytułu nieważności małżeństwa. Kan. 1683 MIDI stanowi, że proces skrócony przed biskupem, oprócz zgody obu stron, domaga się także, aby istniały „okoliczności dotyczące faktów lub osób, poparte zeznaniami lub dokumentami, które nie wymagają przeprowadzenia dokładniejszego badania albo dochodzenia oraz w sposób oczywisty wskazują na nieważność". Owa «oczywistość» stanowi klucz do zastosowania procesu przed biskupem. «Oczywistość» jest jednak bardzo «zawiła», jak na to wskazują komentarze do motu proprio papieża Fran-

21 Por. P. Moneta, La dinamica processuale nel m.p. Mitis ludex, s. 7-20, <http://www.consociatio.org/repository/Moneta_Lumsa.pdf>, (data dostępu: 15.04.2015); W. Góralski, Motu proprio..., art. cyt., s. 13.

22 Por. Sobór Watykański II, Konstytucja dogmatyczna o Kościele „Lumen Gentium” (18 listopada 1964), nr 23-27. 
ciszka $^{23}$, chociaż projekt reformy prawa procesowego przygotowała specjalna Komisja pod przewodnictwem Dziekana Roty Rzymskiej.

Nie ma najmniejszej wątpliwości, że troska o zbawienie, w świetle MIDI, pozostaje najwyższym celem instytucji, ustaw i prawa. Natomiast bezpośrednim bodźcem do przeprowadzenia reformy przez papieża Franciszka ,jest ogromna liczba wiernych, którzy choć pragną kierować się własnym sumieniem, coraz częściej odwracają się od struktur prawnych Kościoła wskutek fizycznego lub moralnego oddalenia; miłość i miłosierdzie wymagają, aby Kościół matka stał się bliski swoim dzieciom, które czują się odłączone"24. Reforma prawa procesowego uprzedziła obrady i owoce Synodu z października 2015 oraz ukazała też opcję papieża Franciszka co do małżeństwa i jego istotnych komponentów.

\section{Relacja końcowa Synodu z 2015 roku}

Na wstępie tego punktu należy stwierdzić, że relacja końcowa synodalna nie była aktem magisterium, ale miała być przede wszystkim pomoca dla papieża, który opracuje odpowiedni dokument posynodalny. Relacja końcowa XIV Synodu Biskupów, odbytego w dniach 4-25 października 2015 roku na temat: „Powołanie i misja rodziny w Kościele i w świecie współczesnym”, miała następującą strukturę: dzieliła się na 3 części i zawierała 94 numery. Część I była zatytułowana: Kościót wstuchany w rodzinę. Ta część dzieliła się na 4 punkty: 1. Rodzina i kontekst antropologiczno-kulturowy; 2. Rodzina i kontekst socjalno-ekonomiczny; 3. Rodzina, włączenie i społeczność; 4. Rodzina, uczuciowość i życie. II część Relacji nosi tytuł: Rodzina w planach Boga. Na nią składają się 4 następujące punkty: 1. Rodzina w historii zbawienia; 2. Rodzina w magisterium Kościoła; 3. Rodzina w nauce chrześcijańskiej; 4. Wokół pełnej eklezjalności rodziny. Wreszcie III część zatytułowana: Misja rodziny, także dzieli się na 4 punkty: 1. Formacja rodziny; 2. Rodzina, rodzicielstwo, wychowanie; 3 . Rodzina i towarzyszenie pastoralne; 4. Rodzina i ewangelizacja. W 3 punkcie tej części znajdują się numery 84-86, które dotyczą problematyki wiernych, którzy są rozwiedzeni i zawarli

${ }^{23}$ Por. P. Moneta, La dinamica..., art. cyt., s. 10-13; P. Majer, Art. 5/Tytuł V - Proces małżeński skrócony przed biskupem, w: Praktyczny komentarz..., dz. cyt., s. 163-217; U. Nowicka, Okoliczności dopuszczające rozpoznanie sprawy o nieważność małżeństwa w procesie skróconym przed biskupem, „lus Matrimoniale” 26(2015)3, s. 43-59.

${ }^{24}$ MIDI, preambuła. 
nowe związki małżeńskie ${ }^{25}$. Z punktu widzenia kanonistyki właśnie wymienione numery były przedmiotem wnikliwej analizy autorów, zwłaszcza $\mathrm{nr} 85^{26}$. Za przyjęciem tego numeru głosowało 178 ojców synodalnych (do przyjęcia wymagana była liczba 177 głosów), przy sprzeciwie 80 . W tym punkcie Relacji pominięty został ostatni z warunków dobrej spowiedzi, jakim jest mocne postanowienie poprawy, wyrażające się między innymi decyzją o zaniechaniu współżycia seksualnego $\mathrm{w}$ nowym związku ${ }^{27}$. W prezentowanym punkcie ojcowie synodalni zwracają uwagę na potrzebę uwzględnienia stopnia poczytalności i odpowiedzialności za działanie. Powołują się przy tym na KKK nr 1735 i deklarację Papieskiej Rady ds. Tekstów Prawnych z 24.06.2000. W tym pierwszym dokumencie oznajmia się, że poczytalność (moralna) i odpowiedzialność za działanie mogą zostać zmniejszone, a nawet zniesione, na skutek niewiedzy, nieuwagi, przymusu, strachu, przyzwyczajeń, nieopanowanych uczuć oraz innych czynników psychicznych lub społecznych. Problem polega jednak na tym, że w Relacji nr 85 nie jest jasne, czy mowa o skutkach moralnych (został popełniony grzech lub nie), czy też o skutkach prawno-kanonicznych (osoba może zostać dopuszczona do Komunii św. bądź nie). Z kolei w drugim dokumencie stwierdzono, że osąd sytuacji obiektywnej nie powinien prowadzić do osądu w sprawie «poczytalności subiektywnej». To może sugerować, że istnieje domniemanie braku poczytalności subiektywnej w sytuacji obiektywnie uznawanej za ciężko zawinioną moralnie. Takie domniemanie byłoby sprzeczne z ogólnie przyjętą zasadą kan. 1321, że gdy nastąpiło zewnętrzne przekroczenie, domniemywa się poczytalność, chyba że co innego by się okazało ${ }^{28}$. Tomasz Jakubiak ponadto zauważa, iż wspomniana deklaracja Papieskiej Rady zawiera stwierdzenie o innym znaczeniu od tego zapisanego w numerze 85. Relacji. W deklaracji jest: szafarz Komunii nie jest w stanie ocenić winy subiektywnej. $\mathrm{Z}$ tego stanowiska, biorąc pod uwagę, że szafarz Komunii nie jest w stanie ocenić ab externo, czy po stronie przyjmującego Komunię św., obiektywnie żyjącego w grzechu ciężkim, istnieją również subiektywne warunki konieczne do popeł-

${ }^{25}$ Tekst relacji <http://press.vatican.va/content/salastampa/en/bollettino/publico/2015/0816/0825. html>, (data dostępu: 24.11.2015); por. P. Ronzani, La questione dei divorziati e risposati civilmente alla luce della Relazione finale del Sinodo 2015, "Stato, Chiese e pluralismo confessionale Rivista telematica" (2016)6, <www.statoechiese.it>, (data dostępu: 15.02.2015), s. 8.

26 Por. P. Ronzani, La questione..., art. cyt., s. 9-17; T. Jakubiak, Synod o rodzinie zwiastunem zmian?, „lus Matrimoniale” 26(2015)3, s. 68-80.

27 Por. wymagania i warunki FC 84.

28 Por. J. Syryjczyk, Kanoniczne prawo karne. Część ogólna. Komentarz, Wydawnictwo Uniwersytetu Kardynała Stefana Wyszyńskiego, Warszawa 2008, s. 108-110; J. Jakubiak, Synod..., art. cyt., s. 77-79. 
nienia grzechu ciężkiego, Papieska Rada ds. Interpretacji Tekstów Prawnych wysunęła wniosek, że szafarz Komunii św. musi odmówić udzielenia rozwiedzionemu, żyjącemu w nowym związku - jako osobie jawnie niegodnej - Komunii św. Tym samym Rada uznała, że nie można domniemywać istnienia u tej osoby braku poczytalności subiektywnej ${ }^{29}$. Co więcej, we wspomnianym już w innym kontekście liście Kongregacji Nauki Wiary z 1994 roku, wśród błędnych opinii uznano dopuszczanie do Komunii rozwiedzionych żyjących w nowym związku na podstawie decyzji samego wiernego po rozmowie z kapłanem, a także pogląd, iż jest możliwe udzielanie Komunii ze względu na ciężkość materii, dobro duchowe osoby, dobro wspólne Kościoła ${ }^{30}$.

Natomiast kard. Kasper wprost stwierdził, że synod otworzył drzwi do Komunii świętej dla rozwiedzionych żyjących w nowych związkach. Jest on zdania, że Ojciec Święty wyda przekonującą adhortację, która przede wszystkim podkreśli radość z chrześcijańskiego małżeństwa, to najważniejsza sprawa. Nierozerwalność małżeństwa nie podlega dyskusji, ale opozycja między miłosierdziem a prawdą Ewangelii nie istnieje $\mathrm{e}^{31}$. Z tego wynika, że mogą być różne interpretacje Relacji końcowej Synodu z 2015 roku ${ }^{32}$.

\section{Adhortacja apostolska Amoris laetitia ${ }^{33}$ - główne wątki i kwestia rozeznania tak zwanych sytuacji ınieregularnych» według papieża Franciszka}

Adhortacja ta została nazwana konstytucją dla rodzin, kartą rodzin, która będzie aktualna na najbliższe dziesięciolecia. Nie pomija ona trudności i wyzwań, ale wskazuje na znaczący wkład miłości małżeńskiej. Mówi o znaczeniu seksualności, widząc w niej wspaniały dar Boga. Zamieszcza vademecum miłości między mężem i żoną. Daje rady dotyczące wychowania dzieci, odniesienia do starszych. Przekonuje, że rodzina jest dobrem, bez którego spo-

\footnotetext{
${ }^{29}$ Por. J. Jakubiak, Synod..., art. cyt., s. 79.

${ }_{30}$ Por. Kongregacja Nauki Wiary, List do biskupów Kościoła katolickiego na temat przyjmowania Komunii świętej ..., dz. cyt., s. 412.

31 Por. Kardynał Kasper, Synod otworzył drzwi do Komunii Świętej dla rozwiedzionych, <http://www.pch24.pl/kardynal-kasper--synod-otworzyl-drzwi-do-komunii-swietej-dlarozwiedzionych,39024,i.html\#ixzz48LGQUDJ1>, (data dostępu: 12.04.2016).

32 Por. Dokument końcowy Synodu może być różnie interpretowany. Rozmowa z ks. prof. Piotrem Mazurkiewiczem, ekspertem Papieskiej Rady ds. Rodziny, KAl (2015)45, z 8.11.2015, s. 12-13.

${ }_{33}$ Ojciec Święty Franciszek, Posynodalna Adhortacja apostolska „Amoris Laetitia” o miłości w rodzinie (19 marca 2016) [dalej: AL].
} 
łeczeństwo nie może się obejść. Amoris laetitia mówi językiem doświadczenia, bez idealizacji i abstrahowania, i dotyka rozlicznych sytuacji małżeństw takimi, jakie są. „Radość miłości” jest tekstem, który zachęca do rozumienia, rozeznawania, towarzyszenia, podbudza do troszczenia się z miłością o życie pojedynczych osób, które tworzą małżeństwa i rodziny w różnych okolicznościach oraz kontekstach kulturowych i społecznych ${ }^{34}$. Sekretarz generalny Synodu Biskupów - kard. Lorenzo Baldisseri - stwierdzit, że dobrym kluczem do lektury adhortacji apostolskiej papieża Franciszka jest „logika duszpasterskiego miłosierdzia”. Papiez - jego zdaniem - ,jasno potwierdza nauczanie o małżeństwie i rodzinie, proponowane jako nieodzowny ideał". Aby uniknąć wszelkiej nadinterpretacji, tłumaczy, że „Kościół w żaden sposób nie może zrezygnować” z głoszenia ludziom młodym „pełnego ideału małżeństwa jako planu Bożego”. W obliczu rozpadu małżeństw - aby „uniknąć wszelkich błędnych interpretacji” zaznacza, że „bardziej istotny niż duszpasterstwo niepowodzeń jest wysiłek duszpasterski na rzecz umocnienia małżeństw i w ten sposób zapobieżenia rozpadom". Jednocześnie przypomina, że, „nie umniejszając wartości ewangelicznego ideału”, trzeba „Z miłosierdziem i cierpliwością towarzyszyć możliwym etapom rozwoju osób formujących się dzień po dniu”, zostawiając przestrzeń dla „miłosierdzia Pana, zachęcającego nas do czynienia możliwego dobra" ${ }^{35}$.

Adhortacja składa się z 9 rozdziałów, podzielonych na 325 punktów. Jej tekst opatrzony jest 391 przypisami, głównie wskazującymi źródła jej treści. 52 razy adhortacja cytuje relację końcową zgromadzenia Synodu z 2014 r., a 84 razy - relację końcową zgromadzenia z 2015 r. W ten sposób papież przyznaje wielkie znaczenie kolegialnej pracy uczestników Synodu. Liczne są odwołania do Ojców Kościoła, teologów średniowiecznych i późniejszych (ze św. Tomaszem z Akwinu na czele - 19 razy), a także autorów współczesnych (nie tylko katolickich, np. do pastora Martina Luthera Kinga). Cytowane są teksty papieży Piusa XI, Piusa XII, Pawła VI, Jana Pawła II, Benedykta XVI i Franciszka, nauczanie Soboru Watykańskiego II i Katechizm Kościoła Katolickiego, a także wypowiedzi urzędów kurii rzymskiej, konferencji episkopatów i uczestników Synodu ${ }^{36}$.

Aspekt kanoniczny ujęcia małżeństwa przez papieża Franciszka domaga się zwrócenia uwagi na sytuacje nieregularne. Papież wprost używa

\footnotetext{
${ }^{34}$ Por. włoska prasa: Amoris laetitia nową konstytucją dla rodzin, $\mathrm{Pb}(\mathrm{KAl}) \mathrm{Rzym}$, Turyn.

${ }_{35}$ Por. Kard. L. Baldisseri, Klucz do adhortacji Amoris laetitia, <http://info.wiara.pl/doc/3076443. Kard-Baldisseri-Klucz-do-adhortacji-Amoris-laetitia>, (data dostępu: 8.04.2015).

36 Por. tamże.
} 
pojęcia «nieregularne» sytuacje. Pod tym pojęciem, jak wynika $\mathrm{z}$ adhortacji AL ${ }^{37}$ i Relacji Synodu 2014 (nr 25), należy rozumieć małżeństwa cywilne, rozwiedzionych żyjących w nowych związkach lub osoby, które jedynie mieszkają razem. Ojcowie synodalni osiągnęli konsens, który papież popiera, że w stosunku do wymienionych sytuacji obowiązkiem Kościoła jest ukazanie im Bożej pedagogii łaski w ich życiu i dopomożenie im w osiągnięciu pełni planu Boga. W tym kontekście przestrzega, aby się Kościołowi nie przytrafiło pomylenie dróg: „Dwie logiki spotykamy w całych dziejach Kościoła: usuwanie na margines i włączanie [...] Drogą Kościoła, począwszy od Soboru Jerozolimskiego, jest zawsze droga Jezusa: droga miłosierdzia i integracji [...]. Drogą Kościoła jest niepotępianie nikogo na wieczność; ofiarowanie miłosierdzia Boga wszystkim ludziom, którzy szczerym sercem o to proszą [...]. Prawdziwa miłość zawsze jest bowiem niezasłużona, bezwarunkowa i bezinteresowna!"38. Koncepcja papieża Franciszka w stosunku do wymienionych osób, a właściwie do wszystkich ochrzczonych, polega na włączeniu ich w krwiobieg Kościoła, gdyż nikt nie może być potępiony na zawsze, bo to nie jest logika Ewangelii ${ }^{39}$.

Znamienny i dobitny jest tekst nru 299 adhortacji AL oparty na Relacji końcowej 2015, nr 84: „Przyjmuję rozważania wielu Ojców synodalnych, którzy zechcieli stwierdzić, że «osoby ochrzczone, które się rozwiodły i zawarły ponowny związek cywilny, powinny być bardziej włączane we wspólnoty chrześcijańskie na różne możliwe sposoby, unikając wszelkich okazji do zgorszenia. Kluczem duszpasterskiego towarzyszenia im jest logika integracji, aby nie tylko wiedziały, że należą do Ciała Chrystusa, którym jest Kościół, lecz aby mogły mieć tego radosne i owocne doświadczenie. Są ochrzczeni, są braćmi i siostrami, Duch Święty rozlewa w nich dary i charyzmaty dla dobra wszystkich. Ich udział może wyrażać się w różnych posługach kościelnych: trzeba zatem rozeznać, które z różnych form wykluczenia obecnie praktykowanych w dziedzinie liturgicznej, duszpasterskiej, edukacyjnej oraz instytucjonalnej można przezwyciężyć. Oni nie tylko nie muszą czuć się ekskomunikowani, ale mogą żyć i rozwijać się jako żywe członki Kościoła, odczuwając, że jest on matką, która ich zawsze przyjmuje, troszczy się o nich z miłością i wspiera ich na drodze życia i Ewangelii. Ta

37 Por. AL 296-297; Franciszek, Katecheza (24 czerwca 2015), „L'Osservatore Romano”, wyd. polskie, (2015)7-8, s. 51.

${ }^{38}$ Franciszek, Homilia podczas Mszy św. z nowymi kardynałami (15 lutego 2015), „L'Osservatore Romano", wyd. polskie, (2015)2, s. 35; AL 296.

39 Por. AL 297. 
integracja jest też potrzebna ze względu na troskę i chrześcijańskie wychowanie ich dzieci, które muszą być uznane za najważniejsze»” .

Na pewno rzeczywiście tak bywa, że w niektórych wspólnotach są praktykowane różne formy wykluczenia z posług kościelnych osób będących w sytuacjach «nieregularnych». Zatem obowiązkiem duszpasterzy staje się zadanie rozeznania, na ile te osoby mogą być włączone w różne formy zaangażowania i udziału w dziedzinie liturgicznej ${ }^{40}$, duszpasterskiej ${ }^{41}$, edukacyjnej ${ }^{42}$ oraz instytucjonalnej ${ }^{43}$. Oczywiście to włączenie musi być zgodne z przepisami prawa kanonicznego. Trzeba jednak zauważyć, że zgodnie z obecną praktyką i dyscypliną Kościoła, zapisaną w numerze 1650 KKK, rozwiedzeni, którzy żyją w nowych związkach, nie mogą pełnić pewnych funkcji w Kościele. Zatem można zauważyć pewną trudność, a nawet sprzeczność.

Podążając dalej za papieżem Franciszkiem, należy akcentować właściwe i kompleksowe rozeznanie duszpasterskie. „To rozeznanie nigdy nie może nie brać pod uwagę wymagań ewangelicznej prawdy i miłości proponowanej przez Kościół. Aby tak się stało, trzeba zapewnić niezbędne warunki pokory, dyskrecji, miłości do Kościoła i jego nauczania, w szczerym poszukiwaniu woli Bożej i chęci osiągnięcia na nią odpowiedzi doskonalszej. Postawy te mają fundamentalne znaczenie, aby uniknąć poważnego ryzyka przesłań błędnych, jak idea, że jakiś kapłan może szybko zgodzić się na „wyjątki”, lub że są ludzie, którzy mogą uzyskać przywileje sakramentalne w zamian za przysługi. Kiedy mamy do czynienia z osobą odpowiedzialną i dyskretną, która nie domaga się stawiania swoich pragnień ponad dobro wspólne Kościoła, i duszpasterzem, który potrafi rozpoznać powagę kwestii, jaką rozważa, to unika się niebezpieczeństwa, że pewne określone rozeznanie doprowadzi do myślenia, iż Kościół popiera podwójną moralność" ${ }^{4}$. Kościół nie chce przy

\footnotetext{
$40 \mathrm{~Np}$. lektor, kantor, ministrant, sprawowanie posługi słowa, przewodniczenie modlitwom liturgicznym (KPK, kan. 230), udzielanie chrztu (kan. 861), rozdzielanie komunii (kan. 230 i 943), nadzwyczajny świadek urzędowy przy zawieraniu małżeństwa (kan. 1112), chrzestny (kan. 874), świadek bierzmowania (kan. 893), szafarz sakramentaliów (kan. 1168,1169, 1172), przewodniczenie obrzędom pogrzebowym (Obrzędy pogrzebu dostosowane do zwyczajów diecezji polskich, nr 19, Katowice 2009, s. 17).

${ }^{41} \mathrm{~Np}$. członek diecezjalnej bądź parafialnej rady duszpasterskiej (kan. 512 i 536), członek diecezjalnej lub parafialnej rady ekonomicznej (kan. 492, 537)

42 Np. nauczyciela religii, katechisty (kan. 776 i 804), wykładowcy na uczelni lub wydziale katolickim (kan. 810).

43 Np. pracownikiem sądowym ( kan. 1421, 1428, 1435) lub kurialnym (kan. 483, 494).

${ }^{44}$ AL 300.
} 
tym minimalizować wymagań Ewangelii, ale ma solidną refleksję na temat uwarunkowań i okoliczności łagodzących ${ }^{45}$. W związku z tym papież zaznacza i podkreśla: „Dlatego nie można już powiedzieć, że wszyscy, którzy są w sytuacji tak zwanej «nieregularnej», żyją w stanie grzechu śmiertelnego, pozbawieni łaski uświęcającej [podkreślenie HS]. Ograniczenia nie zależą tylko od ewentualnej nieznajomości normy. Podmiot, choć dobrze zna normę, może mieć duże trudności w zrozumieniu «wartości zawartych w normie moralnej», lub może znaleźć się w określonych warunkach, które nie pozwalają mu działać inaczej i podjać inne decyzje bez nowej winy. Jak to dobrze powiedzieli Ojcowie synodalni, «mogą istnieć czynniki, które ograniczają zdolność podejmowania decyzji». Św. Tomasz z Akwinu uznał, że ktoś może posiadać łaskę i miłosierdzie, ale może nie wypełniać którejkolwiek z cnót , tak, że nawet posiadając wszystkie wlane cnoty moralne nie ukazuje wyraźnie istnienia żadnej z nich, ponieważ zewnętrzne działanie tej cnoty napotyka na trudność: kiedy powiada się, że niektórzy święci nie posiadali pewnych cnót, to jednak mieli sprawności wszystkich cnót"46.

$\mathrm{Z}$ powyższego stwierdzenie papieża można wyprowadzić bardzo doniosły i brzemienny w skutki wniosek. Wynika z niego, że są osoby będące w sytuacji tak zwanej «nieregularnej», nie żyją w stanie grzechu śmiertelnego i nie są pozbawione łaski uświęcającej, z uwagi na uwarunkowania i okoliczności łagodzące. Jan Paweł II także przyznawał, że mogą zaistnieć sytuacje bardzo złożone i niejasne pod względem psychologicznym, które wywierają wpływ na podmiotową poczytalność grzesznika ${ }^{47}$. Kluczowym elementem duszpasterstwa jest rozeznawanie $^{48}$ sytuacji i dojrzałość sumienia tych osób. Sumienie może uznać nie tylko to, że dana sytuacja nie odpowiada obiektywnie ogólnym postanowieniom Ewangelii. Może także szczerze i uczciwie uznać to, co w danej chwili jest odpowiedzią wielkoduszną, jaką można dać Bogu i odkryć z jakąś pewnością moralną, że jest to dar, jakiego wymaga sam Bóg pośród konkretnej złożoności

45 „Poczytalność i odpowiedzialność za działanie mogą zostać zmniejszone, a nawet zniesione, na skutek niewiedzy, nieuwagi, przymusu, strachu, przyzwyczajeń, nieopanowanych uczuć oraz innych czynników psychicznych lub społecznych". KKK 1735.

${ }^{46}$ AL 301; por. Relacja końcowa 2015, nr 51; Tomasz z Akwinu, Summa Theologiae, I-II, q. 65, a.3, ad 2 i ad 3.

47 Por. Jan Paweł II, Adhortacja apostolska „Reconciliatio et paenitentia” o pojednaniu i pokucie $w$ dzisiejszym posłannictwie Kościoła (2 grudnia 1984), nr 17.

48 Jest ono dynamiczne i zawsze powinno być otwarte na nowe etapy rozwoju i nowe decyzje pozwalające na zrealizowanie ideału w pełniejszy sposób. 
ograniczeń, chociaż nie jest to jeszcze w pełni obiektywny ideał ${ }^{49}$. Ze względu na uwarunkowania i czynniki łagodzące możliwe jest, że pośród pewnej obiektywnej sytuacji grzechu osoba, która nie jest subiektywnie winna albo nie jest w pełni winna, może żyć w łasce Bożej, może kochać, a także może wzrastać w życiu łaski i miłości, otrzymując w tym celu pomoc Kościoła. Owa pomoc Kościoła, zdaniem papieża Franciszka, mogłaby to być również pomoc sakramentów. W tekście głównym adhortacji jest mowa o pomocy Kościoła, natomiast w przypisie 351. pisze papież wprost o pomocy sakramentalnej. Całość tego przypisu brzmi następująco: „W pewnych przypadkach mogłaby to być również pomoc sakramentów. Dlatego «kapłanom przypominam, że konfesjonał nie powinien być salą tortur, ale miejscem miłosierdzia Pana (Adhort. Apost. „Evangelii gaudium” [24listopada 2013], 44: AAS 105(2013), 1038).Zaznaczam również,że Eucharystia «nie jest nagrodą dla doskonałych, lecz szlachetnym lekarstwem i pokarmem dla słabych» (tamże, 47:1039)". To bardzo odważne wskazania papieskie, uzasadniane wywodami zwłaszcza św. Tomasza. Co więcej, nawet gorąco prosił, by w rozeznawaniu duszpasterskim kierować się nauką Akwinaty. Papież w tym kontekście wyartykułował jego nauczanie: „Chociaż w ogólnych zasadach istnieje jakaś konieczność, to jednak im bardziej schodzi do szczegółów, tym łatwiej o uchybienia. [...] W dziedzinie postępowania, nie we wszystkich jest ta sama prawda lub poprawność działania, gdy chodzi o szczegóły, a tylko gdy chodzi o ogólne zasady. A i u tych, w których jest ta sama poprawność $\mathrm{w}$ poszczególnych sprawach, nie jest wszystkim znana $\mathrm{w}$ równym stopniu. [...] Im bardziej schodzi się w szczegóły, tym więcej mnoży się sposobów uchybienia" ${ }^{2}$. Normy ogólne stanowią pewne dobro, ale w swoich sformułowaniach nie mogą obejmować absolutnie wszystkich szczególnych sytuacji. Jednocześnie to, co stanowi część rozeznania praktycznego w obliczu konkretnej sytuacji, nie może być podnoszone do rangi normy. To nie tylko doprowadziłoby do nieznośnej kazuistyki, ale zagroziłoby wartościom, które powinny być strzeżone ze szczególną starannością"51. W tym znaczeniu św. Tomasz, odnosząc się do ogólnej znajomości normy oraz szczególnej znajomości rozeznania praktycznego, stwierdzał, że ,jeśli istnieje tylko jedno z dwóch poznań, to lepiej byłoby, żeby było to poznanie rzeczywistości partykularnej, które jest bliższe działaniu" 52 .

49 Por. AL 303.

50 Tomasz z Akwinu, Summa Theologiae I-II, q. 94, ad 4.

51 Franciszek, Przemówienie na zakończenie XIV Zgromadzenia Ogólnego Synodu Biskupów (24 października 2015), „L’Osservatore Romano”, wyd. polskie, (2015)11, s. 12.

52 Por. Sententia libri Ethicorum, VI, 6 (Leonina, t. XLVII, 354). 
Kwestię przypisu 351. podjął również kard. Gerard Müller podczas spotkania z seminarzystami w Oviedo w Hiszpanii 30 kwietnia 2015 r. Wyjaśnił, że przypis nr 351, w którym jest mowa o „pomocy sakramentów", odnosi się ogólnie do obiektywnych sytuacji grzechu, a nie do tego konkretnego przypadku rozwiedzionych, którzy wstąpili w nowe związki. Podkreślił przy tym, że w Amoris laetitia papież nie stwierdza, że rozwiedzeni żyjący w nowym związku mogą przystępować do komunii. „Gdyby Franciszek chciał zmienić tak ważną i głęboko zakorzenioną dyscyplinę, powiedziałby to jasno i podałby tego powody - podkreślił prefekt ${ }^{53}$. Wykład Prefekta Kongregacji Nauki Wiary był szeroko komentowany w hiszpańskich mediach, które jednocześnie zamieściły krytykę ze strony arcybiskupa Madrytu Carlosa Osoro Sierry. Te dwie wypowiedzi hierarchów pokazują, jak różnorodnie będzie komentowana adhortacji apostolska Amoris laetitia i zapewne będą też głosy, że rozeznanie sytuacji nieregularnych może również prowadzić do Komunii św.

Nie ma najmniejszej wątpliwości, że działaniom duszpasterskim, które proponuje papież Franciszek towarzyszy logika miłosierdzia, włączenia i integracji z Kościołem. Należy też pamiętać, że Kościół w żadnym przypadku nie może wyrzec się proponowania pełnego ideału małżeństwa, planu Bożego w całej swej okazałości. Zrozumienie sytuacji wyjątkowych nigdy nie oznacza ukrywania światła pełniejszego ideału ani proponowania mniej, niż to, co Jezus oferuje człowiekowi. Jednak ze świadomości, jaką wagę mają okoliczności łagodzące -psychologiczne, historyczne, a nawet biologiczne - wynika, że „nie pomniejszając wartości ewangelicznego ideału, należy z miłosierdziem i cierpliwością towarzyszyć możliwym etapom rozwoju osób formujących się dzień po dniu”, czyniąc miejsce dla „miłosierdzia Pana, zachęcającego nas do czynienia możliwego dobra"54.

Pasterz Kościoła Powszechnego, w związku z taki propozycjami, próbuje się wczuć także w sytuacje kapłanów, którym przyjdzie rozeznawać razem z małżonkami ich możliwości włączenia. Dość nieoczekiwanie stwierdza, że rozumie tych, którzy wolą duszpasterstwo bardziej rygorystyczne, nie pozostawiające miejsca na żadne zamieszanie. Papież szczerze jednak wierzy, że Jezus Chrystus pragnie Kościoła zwracającego uwagę na

${ }^{53}$ Kard. G. Müller o komunii św. dla rozwodników, <http://www.pch24.pl/kard--mueller-o-komunii-dla-rozwodnikow--nie-mozna-zyc-w-stanie-laski--a-zarazem-w-stanie-grzechu-,43034,i.html\#ixzz48HZPh0aD>, (data dostępu: 6.05.2015).

${ }^{54}$ Por. AL 307 i 308. 
dobro, jakie Duch Święty szerzy pośród słabości: Matki, która wyrażając jednocześnie jasno obiektywną naukę „nie rezygnuje z możliwego dobra, lecz podejmuje ryzyko pobrudzenia się ulicznym błotem" ${ }^{55}$. Franciszek jest przekonany, że kapłani proponujący wiernym pełny ideał Ewangelii i nauczanie Kościoła, muszą im także pomagać w przyjęciu logiki współczucia dla słabych i unikania prześladowania lub osądów zbyt surowych czy niecierpliwych, bo wtedy życie zawsze się komplikuje. Jezus jednak oczekuje, by zrezygnowali z poszukiwania osobistych lub wspólnotowych środków ochronnych, pozwalających zachować dystans w stosunku do istoty ludzkiej udręki, tak by rzeczywiście chcieli wejść w kontakt z konkretnym życiem innych i poznali moc czułości ${ }^{56}$. Logika włączenia powinna bowiem dominować w Kościele, który jest ojcowskim domem, gdzie jest miejsce dla każdego z jego trudnym życiem ${ }^{57}$.

Problematykę poruszaną w tym punkcie opracowania, biorąc pod uwagę niezliczoną różnorodność poszczególnych sytuacji, można podsumować słowami adhortacji AL nr 300: „nie należy oczekiwać od Synodu ani też od tej adhortacji nowych norm ogólnych typu kanonicznego, które można by stosować do wszystkich przypadków. Możliwa jest tylko nowa zachęta do odpowiedzialnego rozeznania osobistego i duszpasterskiego indywidualnych przypadków, które powinno uznać, że ponieważ «stopień odpowiedzialności nie jest równy w każdym przypadku», to konsekwencje lub skutki danej normy niekoniecznie muszą być takie same. Zadaniem kapłanów jest «towarzyszenie osobom zainteresowanym na drodze rozeznania, zgodnie z nauczaniem Kościoła i wytycznymi biskupa. W tym procesie przydatne będzie dokonanie rachunku sumienia, przez chwile refleksji i skruchy. Osoby rozwiedzione, które zawarły ponowny związek, powinny zadać sobie pytanie, w jaki sposób zachowywały się wobec swoich dzieci, gdy związek małżeński przeżywał kryzys; czy były próby pojednania; jak wygląda sytuacja opuszczonego małżonka; jakie konsekwencje ma nowa relacja dla pozostałej rodziny i wspólnoty wiernych; jaki przykład daje ona ludziom młodym, którzy przygotowują się do małżeństwa. Szczera refleksja może umocnić zaufanie w miłosierdzie Boże, które nikomu nie jest odmawiane». Chodzi o proces towarzyszenia i rozeznania, który kieruje tych wiernych do uświadomienia sobie swojej sytuacji przed Bogiem”.

\footnotetext{
55 Franciszek, Adhortacja apostolska „Evangelli Gaudium” o głoszeniu Ewangelii w dzisiejszym świecie (24 listopada 2013) [dalej: EG], nr 45.

56 Por. AL 308.

57 Por. EG 47.
} 
Franciszka o małżeństwie została potwierdzona zasada o bezwzględnej nierozerwalności małżeństwa ważnie zawartego i dopełnionego wpisanej w jego naturę. W nauczaniu Papież kładzie akcent na piękno miłości małżeńskiej i życia rodzinnego, pomimo ich kryzysu. W oryginalny sposób przedstawia płodny wymiar miłości, odwołując się do hymnu o miłości św.Pawła,tworząc w ten sposóbduchowąiegzystencjalnąmedytację ${ }^{58}$.Kładzie nacisk na potrzebę włączenia we wspólnotę Kościoła osób żyjących w sytuacjach «nieregularnych», aby czuły się przedmiotem niezasłużonego, bezwarunkowego i bezinteresownego miłosierdzia ${ }^{59}$. Aby mogły mieć tego radosne i owocne doświadczenie, ich udział może się wyrażać w różnych posługach kościelnych, które należy rozeznać. $Z$ nauczania papieża Franciszka jednak nie wynika, że wymienione osoby, po rozeznaniu, po uwzględnieniu kwestii poczytalności i odpowiedzialności, mogły by korzystać z Komunii św., nie wypełniając wszystkich warunków wyartykułowanych przez Jana Pawła II w FC nr 84. Papież wyraźnie podkreśla, że nie ma mowy, żeby była jakaś podwójna moralność, żeby księża sobie pozwalali na wydawanie decyzji, które się nie mieszczą w Magisterium. Tezy kard. Kaspera, choć były inspirujące dla Synodu i Papieża, nie do końca znalazły uznanie.

${ }^{58}$ Por. Kard. Baldisseri, Klucz...., art. cyt., punkt 1.

59 Por. AL 297. 


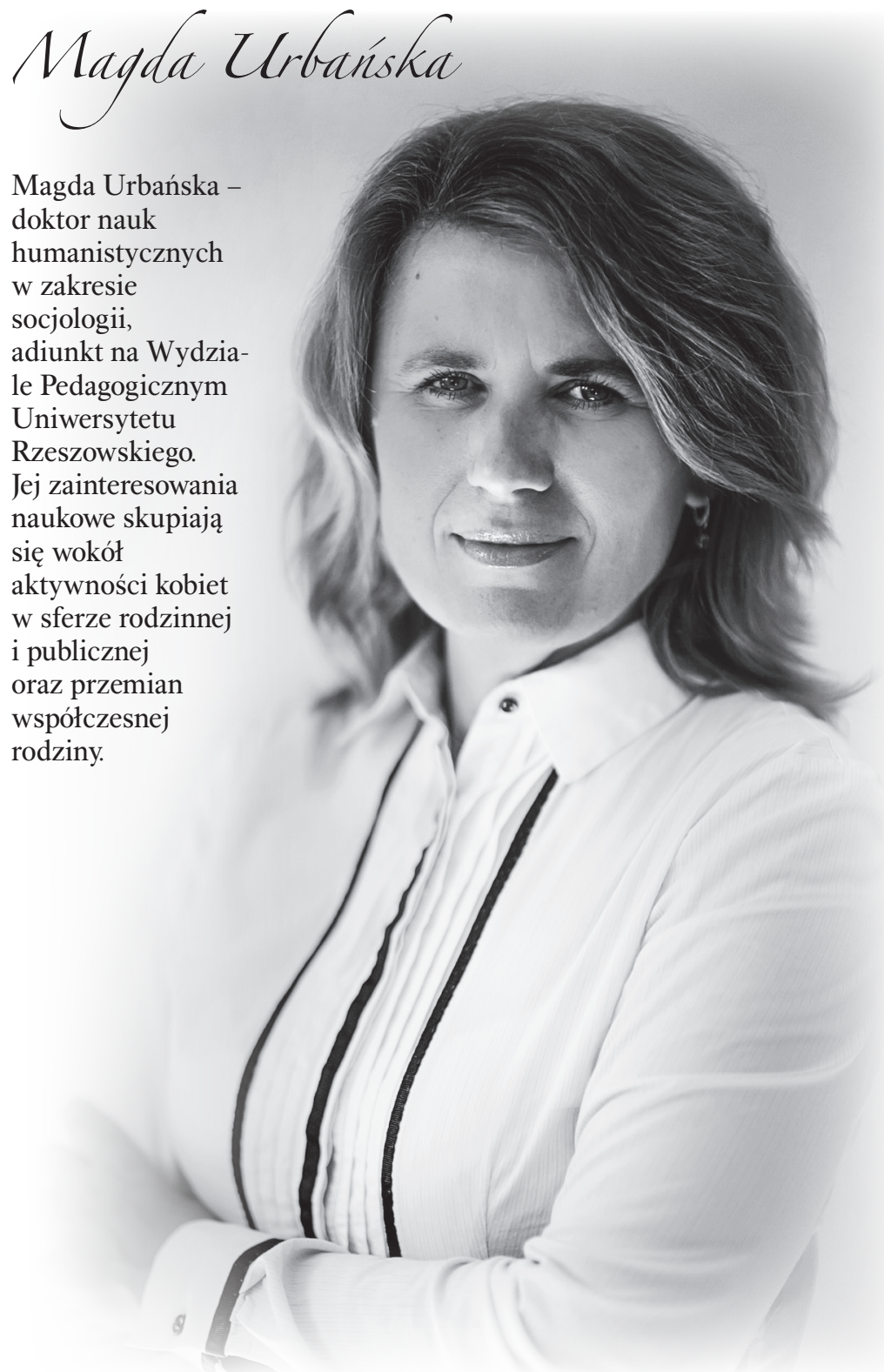




\section{Magda Urbańska \\ Uniwersytet Rzeszowski \\ Preferowany model rodziny w opiniach młodzieży}

Wprowadzenie

Przemiany dokonujące się we współczesnym świecie rzutują także na rodzinę. Jeszcze do niedawna podstawą rodziny było małżeństwo, obecnie coraz częściej - obok rodziny nuklearnej opartej na związku formalnym - współwystępują różnorodne formy życia małżeńsko-rodzinnego. Niejako na naszych oczach zmienia się model rodziny. Coraz częściej związki nie są formalizowane, a kohabitacja staje się alternatywą dla małżeństwa. Młodzi ludzie uczą się ról rodzinnych w związkach innych niż małżeństwo. Odsuwane są w czasie decyzje o zawarciu związku małżeńskiego oraz urodzeniu pierwszego dziecka. W coraz większym stopniu aprobowany jest styl życia singla. Wzrasta liczba rozwodów i rodziców samotnie wychowujących dzieci. Stopniowo aprobowane są także inne niż tradycyjna rodzina nuklearna formy związków rodzinnych. Przekłada się to na zróżnicowanie w zakresie modeli życia rodzinnego, w coraz większym stopniu dopasowujących się do indywidualnych potrzeb i oczekiwań jednostek.

Coraz częściej pada także pytanie: jaki rodzaj związku jest rodziną? Jak definiować rodzinę? Równolegle funkcjonują bowiem dwa modele życia rodzinnego: małżeństwo, zawierane przez większość ludzi, którzy wychowują w nim swoje dzieci, oraz alternatywne formy życia małżeńsko-rodzinnego ${ }^{1}$. Obok tradycyjnej rodziny nuklearnej, którą stanowią małżonkowie z dziećmi, funkcjonują także nietradycyjne rodziny, które są jej odmianą, nie posiadają jednak takich cech jak: usytuowanie prawne, trwanie przez całe życie, wyłączność seksualna

\footnotetext{
Por. K. Slany, Ponowoczesne rodziny - konstruowanie więzi i pokrewieństwa, w: Zagadnienia małżeństwa i rodzin w perspektywie feministyczno-genderowej, red. K. Slany, Wydawnictwo Uniwersytetu Jagiellońskiego, Kraków 2013, s. 46.
} 
pomiędzy jedną kobietą i jednym mężczyzną w związku małżeńskim, posiadanie dzieci, wysoka pozycja mężczyzny ${ }^{2}$. A. Kwak definiuje je jako „układy wzajemnych powiązań seksualnych i rodzinnych, które nie są usankcjonowane prawnie i/lub nie posiadają biologicznego rodzicielstwa"3. Wśród alternatywnych form życia małżeńsko-rodzinnego wymieniane są najczęściej: związki kohabitacyjne, samotni rodzice, związki typu LAT (ang. Living Apart Together, pary mieszkające oddzielnie), małżonkowie DINKS (ang. Double Income No Kids, intencjonalnie bezdzietni, skupieni na karierze zawodowej), rodziny zrekonstruowane, grona przyjacielskie, układy sieciowe seniorów, związki osób tej samej płci, single 4 . W tym kontekście A. Kwak zwraca uwagę na trudności definicyjne, związane z pojęciem rodziny. Jeszcze do niedawna rodzina definiowana była poprzez heteroseksualność, związek formalny oraz posiadanie dzieci, obecnie tak rozumiana rodzina nuklearna stała się zaledwie jednym z modeli życia rodzinnego ${ }^{5}$. Według T. Szlendaka, alternatywne modele rodziny są „,rodzinami skrojonymi na miarę czasów indywidualizacji”"6.

\section{Przemiany modelu rodziny}

Z. Tyszka wiąże przemiany rodziny ze stadiami rozwojowymi społeczeństwa, wyróżniając rodzinę epoki preindustrialnej, industrialnej i postindustrialnej ${ }^{7}$. Pierwsza ze wskazanych rodzin to tradycyjna rodzina patriarchalna, podporządkowana woli i władzy ojca. Praca w niej odbywała się w rodzinnych warsztatach i angażowała wszystkich członków rodziny. Rodzina nadawała status społeczny, była przede wszystkim instytucją ekonomiczną i opiekuńczo-socjalizacyjną. Cechowała się dużą spójnością, przewagą stosun-

2 Por. A. Kwak, Rodzina w dobie przemian. Małżeństwo i kohabitacja, Wyd. Akademickie Żak, Warszawa 2005, s. 84.

3 Tamże, s. 91.

${ }^{4}$ Por. tamże; K. Slany, Alternatywne formy życia małżeńsko-rodzinnego w ponowoczesnym świecie, Zakład Wyd. Nomos, Kraków 2008, s. 84-85; M. Sikorska, Nowa matka, nowy ojciec, nowe dziecko. O nowym układzie sił w polskich rodzinach, Wyd. Akademickie i Profesjonalne, Warszawa 2009, s. 135145; T. Szlendak, Socjologia rodziny. Ewolucja, historia, zróżnicowanie, PWN, Warszawa 2010, s. 465.

5 Por. A. Kwak, Refleksje nad współczesną rodziną - kontrowersje, pytania, wartości, w: Współczesna rodzina polska. Przemiany, zagrożenia i wzywania, red. A. Jabłoński, M. Szyszka, D. Gizicka, Wyd. KUL, Lublin 2014, s. 17.

6 T. Szlendak, Socjologia..., dz. cyt., s. 461.

7 Por. Z. Tyszka, Rodzina współczesna - jej geneza i kierunki przemian, w: Rodzina współczesna, red. M. Ziemska, Wydawnictwa Uniwersytetu Warszawskiego, Warszawa 2001, s. $194-198$. 
ków materialno-rzeczowych nad emocjonalno-osobistymi oraz brakiem indywidualistycznych tendencji jej członków. Rodzina preindustrialna to rodzina wielopokoleniowa (duża), wielodzietna, poddana religijnej kontroli, o instytucjonalnym charakterze. Sankcjonowały ją obyczaje i religia. Zmiana nastąpiła w epoce przemysłowej, gdy pod wpływem industrializacji oraz wywołanych przez nią zjawisk (urbanizacja, migracja ludności, rozwój nauki i oświaty) przeobrażeniu uległa także rodzina. Zaczął się wykształcać nowy model zwany „modelem rodziny współczesnej”. Rodzinę rozszerzoną wyparła rodzina mała (dwupokoleniowa), posiadająca oddzielne mieszkanie i prowadząca odrębne gospodarstwo domowe. Osłabieniu uległy więzi, a praca przeniosła się poza domostwo, w tym także praca kobiet. Rodzinna produkcja została zastąpiona przez przemysł. Rodzina stała się bardziej intymna, słabo powiązana z mikrostrukturami wspólnotowymi. Wzrastał wewnętrzny egalitaryzm, zmniejszeniu uległ dystans między małżonkami oraz rodzicami i dziećmi, a także zmalała specjalizacja ról żony i męża. Znaczenia nabrała funkcja emocjonalna. Równocześnie, ze względu na nasilające się konflikty, rodziny stały się bardziej podatne na rozpad. W epoce postindustrialnej nasiliły się wszystkie procesy zainicjowane w poprzednim okresie. Rodzinę postindustrialną cechowały ponadto:

- wzrost zatrudnienia kobiet, spowodowany także pobudkami pozaekonomicznymi,

- egalitaryzm w małżeństwie i rodzinie,

- relatywne zmniejszenie wartości dzieci dla rodziców,

- różnice norm i wartości u poszczególnych członków rodziny,

- wypieranie tradycyjnych wartości rodzinnych,

- indywidualizacja form aktywności w rodzinie i zainteresowań,

- autonomizacja członków rodziny,

- mniejsza spójność, dezintegracja części rodzin,

- spadek odsetka osób pozostających w związkach małżeńskich,

- wzrost odsetka osób żyjących w związkach kohabitacyjnych i żyjących w stanie wolnym,

- większa konfliktowość w małżeństwach, masowość rozwodów,

- patologizacja w życiu rodzinnym ${ }^{8}$.

Model rodziny tradycyjnej i współczesnej przedstawia także W. Majkowski, wskazując na ich istotne komponenty. Do elementów mode-

8 Por. tamże; H. Krzysteczko, Modele i wartości rodziny dawnej i współczesnej, w: Rodzina. Historia i współczesność. Studium monograficzne, red. W. Korzeniowska, U. Szuścik, Oficyna Wydawnicza „Impuls”, Kraków 2006, s. 132-135. 
lu tradycyjnego, utożsamianego z modelem rodziny preindustrialnej, autor zalicza: rodzinne gospodarstwo jako źródło utrzymania rodziny, patriarchalny charakter rodziny, wielodzietność, wielopokoleniowość oraz familializm, związany z silnymi i trwałymi więzami małżeńsko-rodzinnymi oraz dobrem rodziny jako głównym motywem zawierania związku małżeńskiego9. W tym modelu życie poza rodziną było praktycznie niemożliwe, szczególnie dotyczyło to kobiet, dla których „,nawet najgorzej funkcjonujący związek małżeński był sytuacją lepszą niż życie w samotności"10. Postępująca industrializacja, urbanizacja oraz sekularyzacja przyczyniły się do wykształcenia się modelu rodziny współczesnej. Jego wyróżnikami są: małodzietność, akceptacja kontroli poczęć, miłość jako motywacja zawierania związku małżeńskiego, partnerski model rodziny, osłabienie więzi rodzinnej, skutkującej wzrostem odsetka małżeństw rozwodzących się oraz akceptacji społecznej dla rozwodów, a także życie w kohabitacji (związku nieformalnym osób odmiennej płci, wspólnie mieszkających, prowadzących gospodarstwo domowe oraz utrzymujących kontakty intymne $)^{11}$.

Według T. Biernata i P. Sobierajskiego, różnice pomiędzy tymi dwoma modelami rodziny wynikają z detradycjonalizacji, deinsytucjonalizacji i desakralizacji rodziny ${ }^{12}$. Autorzy wiążą detradycjonalizację rodziny $\mathrm{z}$ odejściem od patriarchalnego modelu rodziny na rzecz modelu rodziny partnerskiej (demokratycznej) oraz zwiększeniem znaczenia kobiet w życiu rodzinnym i publicznym, a także zmianami w zakresie relacji w rodzinie. Deinstytucjonalizacja rodziny przejawia się utratą funkcji społecznych rodziny, przejmowanych przez wyspecjalizowane instytucje, np. żłobki, przedszkola, szpitale, domy pomocy społecznej lub inne grupy czy instytucje socjalizacyjne, np. media, grupy rówieśnicze. Rośnie także aprobata dla stosunków przed- i pozamałżeńskich, co sprzyja alternatywnym formom życia rodzinnego. Desakralizacja wiąże się z utratą wymiaru sakralnego i religijnego małżeństwa i rodziny. Laicki model rodziny związany jest z odrzuceniem wartości religijnych oraz nauki Kościoła w kwestii stosunków przedmałżeńskich, antykoncepcji, aborcji czy rozwodów. Religia staje

\footnotetext{
9 Por. W. Majkowski, Zmiana tradycyjnego modelu rodziny w Polsce, w: Rodzina przyszłością świata? W kręgu zamyśleń nad rodziną, red. A. Pryba, Uniwersytet im. Adama Mickiewicza, Toruń 2009, s. 251-256.

10 Tamże, s. 254.

11 Por. tamże, s. 256-264.

12 Por. T. Biernat, P. Sobierajski, Młodzież wobec małżeństwa i rodziny. Raport z badań, Wydawnictwo Uniwersytetu Mikołaja Kopernika, Toruń 2007, s. 11.
} 
się sprawą indywidualną, czego przejawem jest także niewtrącanie się rodziców w życie religijne ich dzieci ${ }^{13}$.

Literatura przedmiotu zwraca uwagę, że rodzina współczesna nie zatrzymała się w procesie zmian. Postępujące procesy indywidualizacji oraz zmiana normi wartości spowodowały większąakceptację dla różnych form wspólnego życia w intymnym związku lub życia w pojedynkę ${ }^{14}$. Pojawia się tzw. syndrom opóźnienia, cechujący sięopóźnianiem zawieraniamałżeństw, odkładaniem decyzji prokreacyjnych na okres późniejszy oraz przedłużeniem zależności od rodziców, co związane jest $\mathrm{z}$ wydłużonym okresem edukacji ${ }^{15}$.Zjawiska te mogą wzajemnie na siebie wpływać lub być traktowane niezależnie od siebie, np. długi okres kształcenia powoduje uzależnienie ekonomiczne od rodziców, co może przekładać się na odraczanie decyzji o zawarciu małżeństwa i posiadaniu dzieci, młodzi ludzie nie wchodzą w związki małżeńskie, co nie musi być związane $\mathrm{z}$ sytuacją materialną, mogą też zawierać małżeństwo, ale odkładać na przyszłość decyzje prokreacyjne $^{16}$. Już teraz widoczna jest w Polsce tendencja spadkowa w zawieranej liczbie małżeństw, wzrasta także wiek nowożeńców (dla mężczyzn średnio 29 lat, dla kobiet 27 lat). Pierwsze małżeństwa zawierane są w coraz starszym wieku - mediana wieku kawalerów zawierających małżeństwo w 2013 r. wynosiła prawie 28 lat, o cztery lata więcej niż na początku lat 90 . XX wieku. Panny miały średnio 26 lat, wobec 22 lat na początku lat 90. Od 1992 r. spada także liczba urodzeń, jednakże widoczny jest wysoki wskaźnik urodzeń pozamałżeńskich, co wynika ze wzrostu liczby rodzin tworzonych przez związki kohabitacyjne ${ }^{17}$.

Według badania CBOS, najbardziej popularnym modelem życia rodzinnego w Polsce jest rodzina mała, nuklearna, składająca się z rodziców i dzieci. Żyje w niej 45\% Polaków, a za najlepszą dla siebie formę życia rodzinnego uważa 55\% ${ }^{18}$. Co trzeci Polak chciałby żyć w rodzinie wielopo-

\footnotetext{
13 Por. tamże, s. 11-14.

14 Por. A. Kwak, Refleksje..., dz. cyt., s. 27.

15 Por. tenże, Od i do małżeństwa i rodziny: „czas” rodziny - „czas” jednostki, w: Wielość spojrzeń na małżeństwo i rodzinę, red. A. Kwak, M. Bieńko, Wydawnictwo Uniwersytetu Warszawskiego, Warszawa 2012, s. 42.

16 Por. tamże, s. 42-43.

17 Por. Główny Urząd Statystyczny, Małżeństwa oraz dzietność w Polsce, Warszawa, styczeń 2016 r., s. 1-2, 4, 8, <www.stat.gov.pl/obszary-tematyczne/ludnosc/ludnosc/malzenstwa-i-dzietnosc-w-polsce,23,1.html>, (data dostępu: 15.06.2016)

18 Por. R. Boguszewski, Rodzina - jej współczesne znaczenie i rozumienie, w: Rodzina i jej przemiany, red. M. Grabowska, CBOS, „Opinie i Diagnozy” (2013)26, s. 22-24.
} 
koleniowej, składającej się z dziadków, rodziców i dzieci (29\%). W porównaniu z badaniem z 2008 r. widoczny jest spadek osób, które chciałyby żyć w rodzinie małej (z 62\% do 55\%), wzrost zwolenników życia w rodzinie poszerzonej (z 26\% do 29\%), a także osób, które chciałyby żyć w pojedynkę (z 2\% do 4\%) oraz w małżeństwach bez dzieci (z 3\% do 4\%) i rodzinie monoparentalnej (z 0\% do 1\%). Widoczny jest spadek w preferencjach dotyczących stałego związku partnerskiego z osobą odmiennej płci (z 7\% do 4\%). Wśród osób żyjących aktualnie w związkach kohabitacyjnych 34\% uważa, że jest to dla nich najlepsza forma związku, a 37\% chciałoby mieć rodzinę złożoną z małżonków i dzieci ${ }^{19}$. Szczegółowe dane dotyczące preferowanego modelu życia rodzinnego zaprezentowano na wykresie 1 .

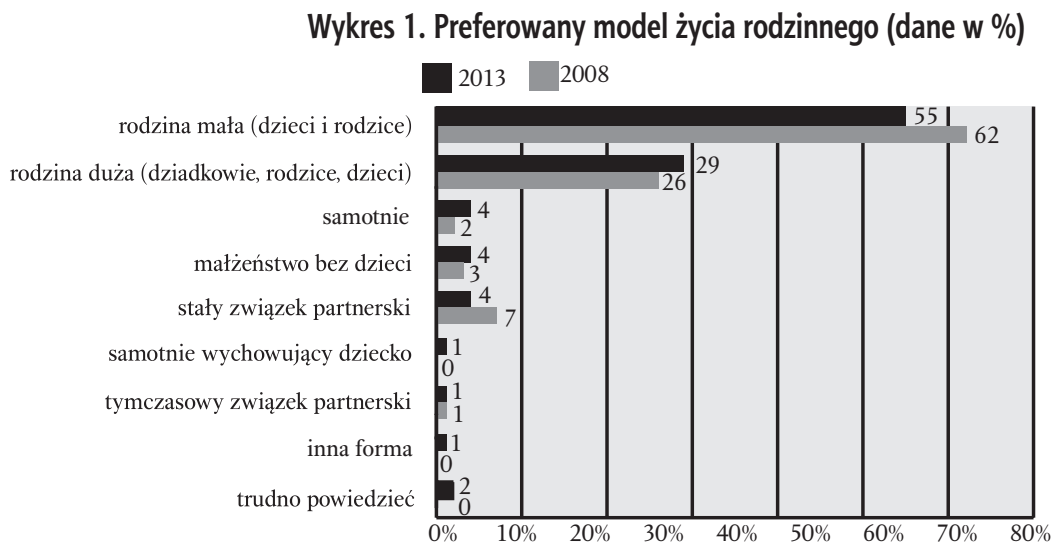

Źródło: R. Boguszewski, Rodzina - jej wspótczesne znaczenie i rozumienie, w: Rodzina i jej przemiany, red. M. Grabowska, CBOS, „Opinie i Diagnozy” (2013)26, s. 24.

\section{Założenia i wyniki badań własnych}

Zgodnie ze stanowiskiem H. Cudaka przyjęto, że model rodziny to „odzwierciedlenie trwale występujących w naszej rzeczywistości rodzinnej określonych zjawisk, tj. zachowań, postaw, relacji wewnątrzrodzinnych"20.

19 Por. tamże, s. 24-25.

20 Z. Frączek, Pokoleniowe przemiany społecznej świadomości wartości rodziny, Wyd. Uniwersytetu Rzeszowskiego, Rzeszów 2011, s. 151. 
Analiza dotyczy wyróżnionego przez F. Adamskiego modelu cząstkowego, ograniczającego się do określonych aspektów rzeczywistości rodzinnej ${ }^{21}$.

Badania zostały przeprowadzone w kwietniu 2014 r. wśród studentów Wydziału Pedagogicznego Uniwersytetu Rzeszowskiego. Miały charakter pilotażowy. W badaniu wykorzystano metodę sondażu. Posłużono się techniką ankiety, przy wykorzystaniu autorskiego kwestionariusza ankiety. Celem badań było poznanie opinii młodzieży akademickiej na temat małżenstwa i kohabitacji oraz ich przekonań dotyczących życia w związku nieformalnym. Sformułowano następujące problemy badawcze: Czy akceptowane jest odkładanie w czasie związku małżeńskiego lub nie zawieranie go? Jakie są tego powody? Czy akceptowane jest wspólne zamieszkanie osób niebędących małżonkami? Jakie są powody braku formalizacji związku? Czy poczęcie dziecka jest bodźcem do zawarcia małżeństwa? Czy związek kohabitacyjny można nazwać rodziną? Jaki jest preferowany rodzaj związku rodzinnego?

W badaniu uczestniczyło 77 studentów kierunku „Nauki o rodzinie” oraz „Pedagogika”. 100\% respondentów stanowiły kobiety. Większość z nich miała 21-24 lata (89,6\%), 7,8\% badanych było w wieku powyżej 24 lat, mniej niż 20 lat miało 2,6\%. Dla potrzeb analizy dokonano podziału respondentek według wieku na mające mniej niż 22 lat $(48,1 \%)$ oraz powyżej 22 lat (51,9\%). Większość respondentek stanowią panny (79,2\%), 18,2\% to partnerki żyjące w związkach kohabitacyjnych, 2,6\% - mężatki. 62,3\% respondentek studiuje na studiach II stopnia, $37,7 \%$ na studiach I stopnia. $58,4 \%$ badanych miesza na wsi, $41,6 \%$ to mieszkanki miasta.

Mając na uwadze „syndrom opóźnienia”, zapytano respondentki, czy akceptują odkładanie w czasie decyzji o zawarciu związku małżeńskie-

${ }^{21}$ F. Adamski stoi na stanowisku, iż aby mówić o całościowym modelu rodziny, należy jednocześnie uwzględnić w analizie takie elementy jak: wyobrażenie o małżeństwie i jego wartości (poglądy na charakter związku małżeńskiego, wymagane cechy współmałżonka, trwałość i rozpad związku małżeńskiego), stosunki i powiązania wewnątrzmałżeńskie (rodzina wielka i mała, pozycje i role małżonków), stosunki rodzice-dzieci (udział ojca i matki w procesie wychowania, metody wychowawcze, kierunek i poziom kształcenia dzieci, zwłaszcza córek), praca zawodowa kobiet i jej konsekwencje dla życia rodzinnego (poglądy na prace zawodową kobiet zamężnych, wpływ pracy zawodowej kobiet na życie rodzinne), potrzeby i dążenia kulturalne (typ potrzeb i oczekiwań dotyczących zakresu ich zaspokajania, typ realizowanych potrzeb kulturalnych), uznawany system wartości (zasady i normy regulujące wewnętrzne życie rodziny, aspiracje i dążenia życiowe w hierarchii uznawanych wartości). Często jednak w praktyce realizowane są tzw. modele cząstkowe, ukazujące określone aspekty rzeczywistości, poprzez skupienie się na jednej lub kilku wymienionych grupach problemowych. Por. F. Adamski, Modele małżeństwa i rodziny a kultura masowa, PWN, Warszawa 1976, s. 27-28. 
go lub całkowitej z niego rezygnacji (wykres 2) i jakie mogą być tego powody (wykres 3).

\section{Wykres 2. Akceptacja dla odkładania w czasie decyzji o zawarciu związku małżeńskiego.}

Coraz częściej ludzie, którzy są w odpowiednim wieku odkładają decyzję o zawarciu związku małżeńskiego lub się na niego nie decydują. Czy akceptuje Pani taką decyzję?

Tak

Nie

Trudno powiedzieć

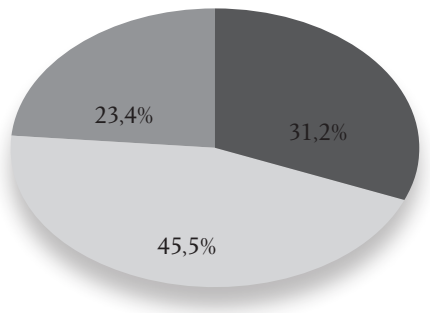

Źródło: badanie własne.

Otrzymane wyniki wskazują, że niemal połowa respondentek (45,5\%) akceptuje sytuację odłożenia w czasie decyzji o zawarciu związku małżeńskiego lub jego nie zawieranie, jednak co czwarta respondentka nie jest temu przychylna (23,4\%). Aż 31,2\% badanych nie potrafiło jednoznacznie określić swojego stosunku do opóźniania w czasie decyzji małżeńskich. Widoczna jest jednak akceptacja dla odkładania w czasie decyzji małżeńskich.

\section{Wykres 3. Powody przemawiające za odłożeniem w czasie decyzji} o zawarciu małżeństwa.

Jakie powody mogą przemawiać za odłożeniem w czasie decyzji o zawarciu związku małżeńskiego?

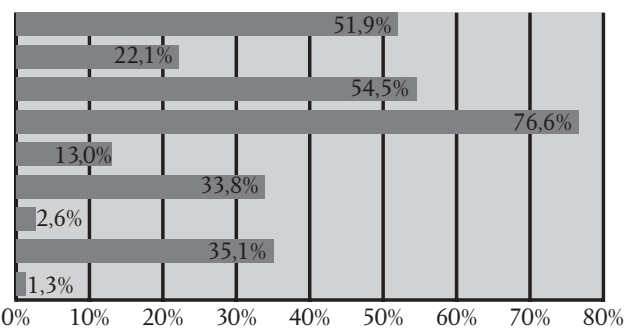

Źródło: badanie własne. Procenty nie sumują się do 100. Respondentki mogły wybrać więcej niż jedną odpowiedź.

Odkładanie w czasie decyzji o zawarciu związku małżeńskiego wynika zdaniem respondentek przede wszystkim ze względów materialnych $(76,6 \%)$ 
i braku mieszkania (54,5\%). Problemem może być także brak odpowiedniego kandydata na męża/żonę (51,9\%). Jako powody odkładania decyzji o zawarciu małżeństwa wskazywano ponadto: nieudane doświadczenia z poprzednich związków (35,1\%), niechęć do sformalizowania związku $(33,8 \%)$, pracę zawodową $(22,1 \%)$ i konieczność dalszej edukacji (13\%). Najrzadziej wskazywanym powodem był braku czasu (2,6\%). Z analizy statystycznej wynika, że badane w wieku powyżej 22 lat bardziej akceptują odkładanie w czasie decyzji matrymonialnych lub całkowitą z nich rezygnację ( $\mathrm{p}=0,03, \mathrm{~V}$ Kramera=0,30, Chi-kwadrat=7,11 $(\mathrm{df}=2)$ ) oraz nieznacznie częściej wskazują na brak mieszkania jako jeden z powodów odłożenia decyzji o zawarciu związku małżeńskiego ( $\mathrm{p}=0,05, \mathrm{Phi}=-0,22$, Chikwadrat=3,67 (df=1)). Z kolei mieszkanki miasta częściej wskazują na niechęć do sformalizowania związku ( $\mathrm{p}=0,04, \mathrm{Phi}=0,23$, Chi-kwadrat=4,21 (df=1)).

Respondentki zapytano, czy akceptują wspólne mieszkanie pary, która nie zawarła związku małżeńskiego (wykres 4), oraz jakie mogą być powody braku formalizacji związku (wykres 5).

\section{Wykres 4. Akceptacja dla wspólnego mieszkania bez zawarcia związku}

Czy akceptuje Pani sytuację gdy para wspólnie mieszka, lecz nie zawarła związku małżeńskiego:

Zdecydowanie tak

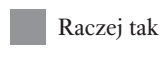

Trudno powiedzieć Raczej nie małżeńskiego.

Zdecydowanie nie

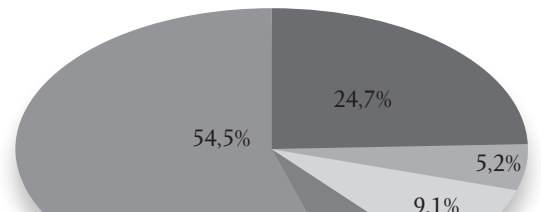

$9,1 \%$

$6,5 \%$

Źródło: badanie własne.

Większość respondentek akceptuje wspólne zamieszkanie pary, która nie zawarła związku małżeńskiego (61\%), jednak w większości ta akceptacja nie jest silna (54,5\%). 14,3\% respondentek nie akceptuje wspólnego mieszkania pary, w tym 9,1\% w sposób zdecydowany jest jej przeciwny. Niemal 1/4 respondentek nie zajęła jednoznacznego stanowiska $(24,7 \%)$. $\mathrm{Z}$ analizy statystycznej wynika, że nieznacznie częściej akceptują wspólne mieszkanie pary niemałżeńskiej respondentki powyżej 22 roku życia $(\mathrm{p}=0,04$, Tau-c Kendalla $=-0,23)$. 


\section{Wykres 5. Powody braku formalizacji związku według respondentek.}

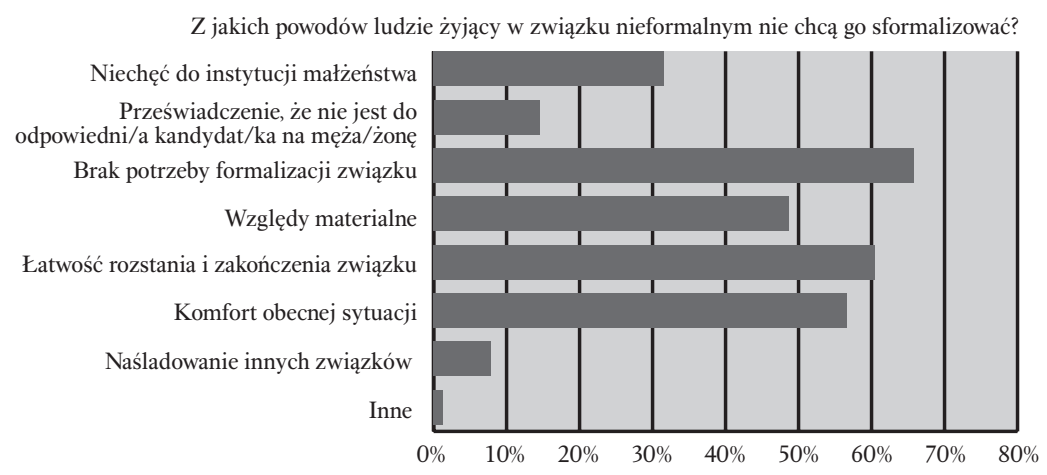

Źródło: badanie własne. Procenty nie sumują się do 100. Respondentki mogły wskazać więcej niż jedną odpowiedź.

Jako powód braku formalizacji związku respondentki wskazują przede wszystkim na brak takiej potrzeby, co można wiązać z przyzwoleniem społecznym $(65,8 \%)$, łatwość rozstania i zakończenia związku $(60,5 \%)$ oraz komfort istniejącej sytuacji $(56,6 \%)$. Nieco rzadziej respondentki wskazują na względy materialne $(48,7 \%)$ oraz niechęć do instytucji małżeństwa (31,6\%). Najrzadziej wskazywanym powodem braku formalizacji związku było przeświadczenie, że aktualny partner nie jest dobrym kandydatem na męża/żonę (14,5\%) oraz naśladowanie innych związków $(7,9 \%)$. $\mathrm{Z}$ analizy statystycznej wynika, że młodsze badane częściej są zdania, że powodem braku formalizacji jest brak takiej potrzeby $(\mathrm{p}=0,05, \mathrm{Phi}=0,22$, Chi-kwadrat=3,61 ( $\mathrm{df}=1)$, dodatkowo rzadziej są zdania, że chodzi o naśladowanie innych związków $(\mathrm{p}=0,02, \mathrm{Phi}=-0,28$, Chi-kwadrat=6,02 $(\mathrm{df}=1)$ ).

Kohabitacja traktowana jest często jako swoista „próba” przed małżeństwem, pozwala bowiem na poznanie partnera w codziennym życiu. Zapytano więc respondentki czy akceptują taką sytuację (wykres 6) oraz czy same chciałyby zamieszkać ze swoim partnerem/partnerką przed ślubem (wykres 7). 
Wykres 6. Akceptacja dla wspólnego mieszkania "na próbę" przed ślubem.

Czy akceptuje Pani sytuację gdy para wspólnie mieszka, lecz nie zawarła związku małżeńskiego:

Zdecydowanie tak
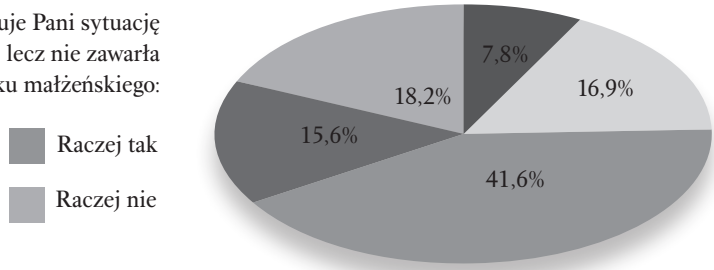

Zdecydowanie nie

Źródło: badanie własne.

Wspólne mieszkanie przed ślubem będące „próbą” przed małżeństwem akceptowane jest przez większość respondentek (58,5\%), w tym $16,9 \%$ jest temu rozwiązaniu zdecydowanie przychylna. Przeciwnego zdania jest $26 \%$, w tym $7,8 \%$ to zdecydowane przeciwniczki tego rodzaju kohabitacji. Brak jednoznacznego stanowiska wskazało 15,6\% respondentek.

\section{Wykres 7. Rozważanie wspólnego zamieszkania przed ślubem przez}

Czy rozważałaby Pani możliwość respondentki. zamieszkania ze swoim partnerem przed ślubem?

Zdecydowanie tak

Trudno powiedzieć

Zdecydowanie nie
Raczej tak

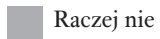

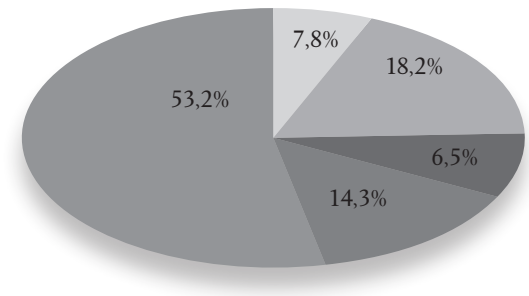

Źródło: badanie własne.

Akceptacja dla wspólnego zamieszkania przed ślubem jako formy „sprawdzenia się" przed ślubem wzrosła jeszcze bardziej, gdy odniesiono ją do hipotetycznej sytuacji osobistej respondentek. Za tym rozwiązaniem opowiedziało się łącznie $67,5 \%$ badanych, rozważając możliwość zamieszkania z własnym partnerem przed ślubem. Na takie rozwiązanie nie zdecydowałoby się $26 \%$ badanych. Zmalał odsetek osób, które nie zajęły jednoznacznego stanowiska (6,5\%).

Mając na uwadze zwiększający się odsetek urodzeń pozamałżeńskich, co łączone jest z coraz większą popularnością związków kohabitacyjnych, zapytano respondentki, czy związek powinien zostać sformalizowany w sytuacji, gdy zostało poczęte dziecko (wykres 8). 


\section{Wykres 8. Formalizacja związku w sytuacji poczęcia dziecka.}

Jeśli w związku nieformalnym zostało poczęte dziecko, to które rozwiązanie jest

Natychmiastowe zawarcie związku małżeńskiego

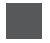

Pani zdaniem najwłaściwsze?

Zawarcie związku małżeńskiego po urodzeniu się dziecka

Decyzja należy do zainteresowanych

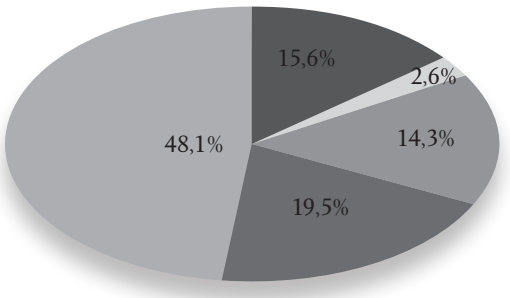

Źródło: badanie własne.

Respondentki uważają, że poczęcie dziecka w związku kohabitacyjnym nie wiąże się jednoznacznie z koniecznością formalizacji związku. Uważano, że decyzja ta powinna należeć przede wszystkim do zainteresowanych $(48,1 \%)$, jednak $35,1 \%$ uważa, że powinno to nastąpić w niedalekiej przyszłości - po urodzeniu się dziecka $(19,5 \%)$ lub natychmiast po uzyskaniu wiadomości o ciąży (15,6\%). Zadaniem 14,3\%, partnerzy nie muszą się pobierać, jeśli tego nie chcą.

Zapytano także respondentki, czy obejmują mianem rodziny osoby żyjące w związkach kohabitacyjnych (wykres 9).

\section{Wykres 9. Związek kohabitacyjny jako rodzina.}

Czy parę mieszkającą razem bez ślubu, prowadzącą wspólnie gospodarstwo domowe, można Pani zdaniem nazwać rodziną?

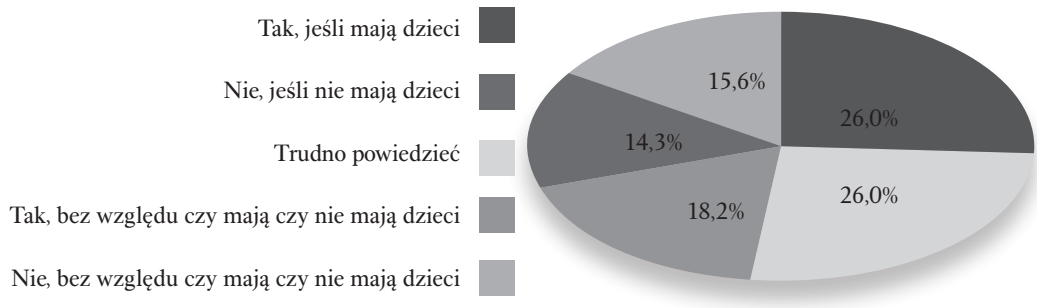

Źródło: badanie własne.

26\% respondentek uważa, że jeśli w związku kohabitacyjnym są dzieci zasługuje on na miano rodziny, podobnie uważa 14,3\% badanych, dla których rodziną nie są tak długo, dopóki nie mają dzieci. 18,2\% respondentek jest prze- 
konanych o tym, że bez względu na to, czy para posiada dzieci, czy ich nie ma można ich nazwać rodzina, przeciwnego zdania jest 15,6\% badanych. Ponad 1/4 badanych (26\%) nie zajęła jednoznacznego stanowiska w tej kwestii.

Mając na uwadze, że najbardziej popularnym związkiem rodzinnym w Polsce jest rodzina, której podstawą jest małżeństwo, zapytano młodzież, jaki jest ich preferowany typ związku (wykres 10).

Wykres 10. Preferowany typ związku.

Jaki typ związku uważa Pani za najwłaściwszy dla siebie?

Związek formalny (małżeństwo)

Związek nieformalny (bez zawarcia związku

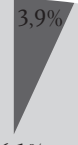

$96,1 \%$ małżeńskiego)

Źródło: badanie własne

Respondentki niemal w całości wskazały małżeństwo jako najbardziej dla nich właściwy rodzaj związku $(96,1 \%)$, tylko niewielki odsetek badanych wskazał na związek kohabitacyjny $(3,9 \%)$.

\section{Podsumowanie}

Podsumowując wyniki badań, należy stwierdzić, że ze względu na ich mały zasięg nie dają one uprawnień do uogólnień, pozwalają jednak przyjrzeć się pewnym tendencjom dotyczącym małżeństwa i związków kohabitacyjnych wśród badanej grupy młodzieży. Wśród studentów widoczna jest akceptacja dla odłożenia w czasie decyzji o zawarciu związku małżeńskiego lub rezygnacji z niego, wskazywane są przy tym zwłaszcza względy ekonomiczne i mieszkaniowe związane $\mathrm{z}$ tego rodzaju decyzją. Badana młodzież akademicka w dużej części akceptuje życie w związku kohabitacyjnym, zwłaszcza jeśli ma on być traktowany jako etap przygotowania do ślubu, a nie jako alternatywa wobec małżeństwa.

Według badanej młodzieży, życie w związku kohabitacyjnym wynika przede wszystkim z przekonania, że nie trzeba zawierać związku małżeńskiego, aby wspólnie mieszkać. Brak potrzeby formalizacji związku moż- 
na powiązać $\mathrm{z}$ akceptowanym społecznie stylem życia kohabitantów i równocześnie brakiem społecznego nacisku na formalizację związku. Zdaniem badanych studentów, za życiem w związku nieformalnym przemawia także łatwość zakończenia związku oraz komfort sytuacji, co może wskazywać na traktowanie kohabitacji jako związku kruchego i nietrwałego w czasie, lecz odpowiadającego aktualnym potrzebom kohabitantów, przy jednoczesnej świadomości, że łatwiej mogą go zakończyć, gdy oczekiwania dotyczące wspólnego życia rodzinnego rozminą się z rzeczywistością. Badana młodzież sprzyja uznaniu związku kohabitacyjnego za rodzinę, zwłaszcza gdy pojawiają się w nim dzieci, choć są także przeciwnicy tego stanowiska. $\mathrm{Z}$ drugiej strony, badane uważają, że poczęcie dziecka nie jest szczególnym powodem, aby formalizować związek. Uzależniają to od decyzji zainteresowanych, jednak same uważają, że zawarcie małżeństwa z powodu ciąży byłoby najwłaściwszym rozwiązaniem. Można przypuszczać, że pojawienie się dziecka w związku kohabitacyjnym sprzyjałoby rozważaniom partnerów na temat formalizacji związku, choć wcześniej mogli nie brać tego pod uwagę. Jako preferowany związek badana młodzież wskazuje małżeństwo, co w kontekście wyników badań pozwala na stwierdzenie, iż mimo akceptacji związków nieformalnych i wspólnego życia przed ślubem, związek formalny jest wyżej ceniony i ma większą wartość.

Kohabitacja nie jest więc związkiem stawianym na równi z małżeństwem. Wydaje się jednak być coraz częściej traktowana jako forma rodziny, niejako w odpowiedzi na pojawiające się nowe potrzeby wynikające z rozwoju cywilizacyjnego współczesnych społeczeństw ${ }^{22}$. Współczesna rodzina ulega bowiem przemianom i życie w kohabitacji, zwłaszcza wśród młodych osób, jest jednym z wymiarów tych przeobrażeń.

22 Por. G. Sanecki, Modele rodziny w preferencjach studentów, w: Edukacja jutra. Problemy współczesnej rodziny, red. K. Denek, A. Kamińska, P. Oleszkiewicz, Oficyna Wydawnicza „Humanitas”, Sosnowiec 2015, s. 33. 
$\$$ 


\section{K. Stanistaw Wilk SDB}

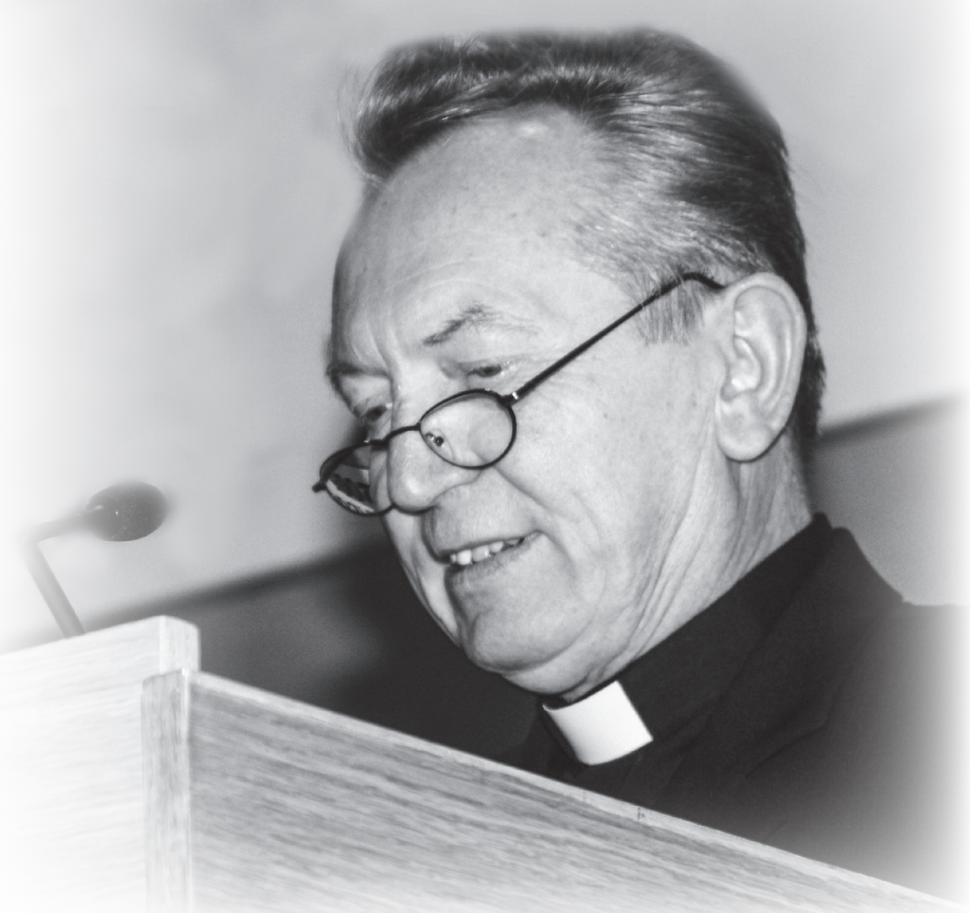

emerytowany profesor zwyczajny KUL. W badaniach naukowych z historii Kościoła XIX i XX wieku interesuje się szczególnie Episkopatem Polski z kard. Augustem Hlondem na czele i dziejami nuncjatury apostolskiej Achillesa Rattiego w II Rzeczypospolitej. 


\section{Kard. August Hlond wobec zagrożeń małżeństwa i rodziny}

Kryzys rodziny w Polsce i na świecie przyjął ogromne rozmiary. Dane statystyczne nie pozostawiają złudzeń: rośnie liczba rozwodów, związków nieformalnych i małżeństw, które nie posiadają dzieci. Własnymi oczyma obserwujemy szybkie starzenie się Europy. Postępująca laicyzacja i wprowadzanie do państwowych systemów prawnych kolejnych przepisów i norm, które burzą tradycyjne pojęcia i funkcje małżeństwa i rodziny, budziły i budzą zrozumiały niepokój nie tylko wśród chrześcijan. Wszyscy, którym leży na sercu przyszłość narodów europejskich i Kościoła w Europie, zastanawiają się, jakie środki i działania należy podjąć, aby przeciwdziałać zgubnym tendencjom społecznym i moralnym. Przyszłość rodziny, grożące jej niebezpieczeństwa, wyzwania i nadzieje, już w ubiegłym wieku stały się przedmiotem obrad międzynarodowych i krajowych kongresów, tygodni i konferencji naukowych poświęconych małżeństwu i rodzinie. Ta problematyka występuje również w soborowych i synodalnych dokumentach Kościoła. Na sakramentalny charakter małżeństwa i konieczność pogłębiania życia religijnego rodzin wskazywali w swym nauczaniu papieże, krajowe episkopaty i poszczególni biskupi, a wśród nich prymas Polski kard. August Hlond.

\section{Rodzina przedmiotem troski Kościoła}

Sakramentalny charakter małżenstwa i prawa rodziny zawsze były, a szczególnie w ostatnim stuleciu, przedmiotem troski Kościoła katolickiego. To zatroskanie można łatwo prześledzić, poczynając od encykliki Casti connubii Piusa XI, poprzez dokumenty Unii Mechlińskiej, Konstytucję duszpasterską o Kościele w świecie współczesnym Soboru Watykańskiego II, encykli- 
kę Humanae vitae Pawła VI, Kartę Praw Rodziny, aż do adhortacji Familiaris consortio i całego nauczania św. Jana Pawła II oraz jego następców na stolicy Piotrowej z adhortacjami Sacramentum caritatis Benedykta XVI i Amoris laetitia papieża Franciszka. Kościół wypowiada się bardzo stanowczo nie tylko w obronie przed błędnymi poglądami i złymi praktykami, naruszającymi godność małżeństwa i rodziny, ale przede wszystkim rozwija teologię małżeństwa i rodziny. W swoim nauczaniu podkreśla miłość jako istotny czynnik więzi rodzinnej, zachęcając do jej praktykowania w odniesieniu do bliźnich oraz do zachowania postawy sprawiedliwości i szacunku dla innych. Przedstawia zasady moralne w dziedzinie przekazywania życia ludzkiego, ukazuje prawa i obowiązki rodziców, dzieci i osób starszych w rodzinie, a także wzywa do upowszechniania praw rodziny i do jej ochrony w ustawodawstwie państwowym.

Pierwszy Polski Synod Plenarny z 1936 roku w swoich uchwałach zalecał wiernym „bronić nierozerwalności małżeństwa, czystości pożycia małżeńskiego i świętości rodziny, a przeciwstawiać się zgubnym w tym względzie zasadom i kierunkom, zwłaszcza fałszywym pojęciom małżeństwa, prądom rozprzęgającym rodzine, propagandzie błędów eugeniki materialistycznej, niemoralnemu ograniczaniu potomstwa i teoriom oraz ustawom dopuszczającym spędzanie płodu"1. Rodzicom zaś przypominał, że rodzina jest pierwszą szkołą nauki religii dla dzieci i wymagał, „aby ojciec i matka rozbudzali wcześnie $\mathrm{w}$ duszach dzieci wiarę w Boga, uczyli pacierza i podstawowych prawd chrześcijańskich oraz dawali dzieciom dobry przykład"2.

$\mathrm{Na}$ obronę życia, świętość małżeństwa, rodzinę Bogiem silną zwracał uwagę Episkopat Polski m.in. w programie Wielkiej Nowenny przed obchodami tysiąclecia chrztu Polski. Biskupi w licznych wypowiedziach i w listach pasterskich podkreślali konieczność prowadzenia polityki prorodzinnej przez państwo i samorządy, by w pokonywaniu problemów i trudności wynikających z wielorakich przemian społeczno-gospodarczych i kulturowych rodzina nie była pozostawiona sama sobie. Wskazywali, że małżeństwa i rodziny polskie potrzebują pomocy nie tylko $\mathrm{w}$ dziedzinie prawno-ekonomiczno-socjalnej, ale również w sferze duchowej i moralnej, a przede wszystkim potrzebują zmiany otaczającej je atmosfery zakłamania, potrzebują przywrócenia zasad etycznych, a także powrotu do Chrystusa oraz nowej ewangelizacji.

\footnotetext{
1 Pierwszy Synod Plenarny w Rzeczypospolitej, Warszawa 1936, art. 62 c.

2 Tamże, art. 119 § 1.
} 
Wiele z tych kwestii omawiał także św. Jan Paweł II podczas swoich pielgrzymek do Ojczyzny. O świętości rodziny i o jej powinnościach mówił podczas homilii w Kielcach (3 czerwca 1991): „Nie odbuduje się zachwianej więzi rodzinnej, nie uleczy się ran powstających z ludzkich słabości i grzechu bez powrotu do Chrystusa, do sakramentu. [...] I ja wołam do Was, Bracia i Siostry, byście rozpalali na nowo Boży charyzmat małżonków i rodziców, jaki jest w Was przez sakrament małżeństwa. Tylko w oparciu o łaskę tego sakramentu możliwe jest pełne przebaczenie, pojednanie i podjęcie na nowo wspólnej drogi. Przez nią odnawia się i ożywia ludzka miłość oraz tożsamość i prawdziwość ludzkich przyrzeczeń. Charyzmat sakramentu małżeństwa to również charyzmat, łaska i dar życia" ${ }^{3}$. W Warszawie zaś podczas rozważania przed modlitwą "Anioł Pański” (9 czerwca 1991) gorąco prosił Matkę Bożą, mówiąc: „Wiemy, że jesteś, Matko. Nie przestajesz być z nami, pomimo naszych słabości i grzechów, pomimo straszliwych nieraz win. Pomóż nam odbudować polską rodzinę jako święte sakramentalne przymierze osób, jako ostoję pokoleń. Niech ta rodzina będzie prawdziwym środowiskiem miłości i życia. Prawdziwym, odpowiedzialnym. Niech będzie pierwszą szkołą wielkiego przykazania miłości - tej miłości, która cierpliwa jest, łaskawa jest, która nie szuka swego, nie pamięta złego, która wspótweseli się z prawda - miłości, która wszystko przetrzyma (1Kor 13,4-7). Pomóż nam odbudować polską rodzinę. Poprzez rodziny przebiega przyszłość człowieka. Od nich zależy przyszłość człowieka na ziemi ojczystej. Od nich zależy przyszłość Polski”4.

\section{Obrona sakramentu małżeństwa w II Rzeczypospolitej}

W nauczanie Kościoła na temat małżeństwa i rodziny wpisują się również wypowiedzi Prymasa Polski kard. Augusta Hlonda. Nie był on ani socjologiem ani ekonomistą, ale był duszpasterzem, nauczycielem wiary i moralności, a także gorącym patriotą. Jako pasterz Kościoła lokalnego, nie mógł pozostać obojętnym wobec problemów i wyzwań, powstających w określonej sytuacji społecznej, gospodarczej i politycznej. W II Rzeczypospolitej nie brakowało kryzysów i sytuacji bardzo trudnych: kryzys gospodarczy, waśnie ideologiczne i polityczne, strukturalne bezrobocie, tendencje

\footnotetext{
3 Czwarta pielgrzymka Jana Pawła Il do Polski, Pallottinum, Poznań-Warszawa 1991, s. $70-71$.

4 Tamże, s. 226.
} 
do laicyzacji życia społecznego, kwestia odbudowy życia kościelnego i trudności z realizacją postanowień konkordatowych. W ich kontekście należy odczytywać nauczanie kard. Hlonda, któremu na sercu leżało bezpieczeństwo i rozwój ojczyzny. Czuł się za nią odpowiedzialny. Dlatego tak mocno przeciwstawiał się komunizmowi i faszyzmowi oraz bronił autorytetu władzy państwowej.

Za jedno z najważniejszych zadań duszpasterskich uważał odnowę i obronę życia rodzinnego. Z jego inicjatywy Naczelny Instytut Akcji Katolickiej zorganizował w 1935 roku w Poznaniu pierwsze Studium Katolickie poświęcone rodzinie. W przemówieniu inaugurującym jego obrady powiedział: „Wstępujemy na majdan ciężkich rozpraw duchowych, by polskiemu życiu wywalczyć zdrowie, tężyznę, wielkość. Niełatwe to bowiem studium. Któż opisze poniżenie dzisiejszego małżeństwa? Czegóż nie przedsięwzięto, by na sztych wystawić rodzinę? Od sąsiada wschodniego wciskają się doktryny określające rodzinę jako środek kolektywizowania przyrostu ludzkiego na rzecz rewolucji bolszewickiej i w ramach jej planu gospodarczego. $\mathrm{Z}$ za innej granicy idą hasła przeorganizowania rodziny na państwowy instytut hodowli czystych wartości rasowych. A najszerzej reklamowano u nas prymat szczęścia osobistego w małżeństwie i określono zarówno małżeństwo jak rodzinę jako zakład użycia, z którego to zakładu można dowolnie wyłączać to wszystko, co ciąży, krępuje i obowiązki nakłada, a przede wszystkim to, co według tej teorii jest najniewygodniejsze, czyli dziecko. Wszak jutrzenkę życia ludzkiego określono jako równoznaczną z piekłem kobiety. Morze atramentu wypisano dla propagandy tych szaleństw. Spuszczono z łańcucha wszystkie chucie, by zaszczuć obrońców świętości ogniska domowego. $Z$ wszystkiego kuto przeciw rodzinie sofistyczne argumenty. Przez te błędy trzeba krytycznie przebrnąć. Katolicka myśl rodzinna domaga się pełnej rehabilitacji od wiedzy i jej przedstawicieli"5.

Inicjatywa kard. Hlonda była bez wątpienia związana ze sprawą kodyfikacji prawa małżeńskiego, która w II Rzeczypospolitej w stosunkach państwo - Kościół budziła wiele kontrowersji, protestów i burzliwych dyskusji prasowych. Do opracowywania zasad projektu prawa małżeńskiego Komisja Kodyfikacyjna przystąpiła już w 1920 roku. Najwięcej kontrowersji budził zamiar wprowadzenia ślubów i rozwodów cywilnych. Na pytanie Komisji Kodyfikacyjnej skierowane do ówczesnego prymasa Polski kard.

\footnotetext{
5 Na otwarcie Studium, w: Rodzina. Pamiętnik I. Katolickiego Studium o Rodzinie w Poznaniu, w dniach 2-6 września 1935, Poznań 1936, s. XII.
} 
Edmunda Dalbora, czy w przypadku ich wprowadzenia biskupi podniosą protest i na tym poprzestaną, czy też wezwą ludność katolicką do walki przeciwko przygotowywanej ustawie małżeńskiej, Komitet Biskupów odpowiedział, że biskupi, jako stróże prawa Bożego i kościelnego, sięgną po wszystkie możliwe środki, łącznie z publicznym napiętnowaniem projektu prawa i z wezwaniem wiernych do walki z nim w obronie świętości sakramentu małżeństwa. Oświadczenie Komitetu Biskupów zaaprobował Zjazd Episkopatu w Krakowie (28 maja - 3 czerwca 1921), który postanowił rozwinąć akcję propagandową przeciw ślubom i rozwodom cywilnym. W liście pasterskim, opracowanym przez abpa Józefa Bilczewskiego i odczytanym z ambon kościołów w całej Polsce w okresie Wielkiego Postu w 1922 roku, biskupi m.in. zalecali wiernym, aby przed wyborami żądali od kandydatów na posłów przyrzeczenia, że nie dopuszczą do wprowadzenia ślubów cywilnych i rozwodów. Gdyby jednak takie prawo zostało uchwalone, to Kościół katolicki go nie uzna, ponieważ bardziej należy słuchać Pana Boga, aniżeli niegodziwych ustaw ludzkich. Biskupi zapewniali też, że: „Sprzecznych z przykazaniem Bożym ustaw nie wpuścimy w nasze rodziny. Narzucone narodowi wyprzemy z Kodeksu ojczystego. Zawołaniem zostanie na całą przyszłość: Małżeństwo wielkim jest w Chrystusie i w Kościele. Co Bóg złączył, ludziom rozwiązać nie wolno!"6.

W trakcie przygotowywania projektu przez Komisję Kodyfikacyjną do opinii publicznej i do Episkopatu nie docierało na jego temat zbyt wiele informacji, ale biskupi na ogół byli zorientowani w postępie prac legislacyjnych, ponieważ w 1924 roku kard. Aleksander Kakowski, z upoważnienia Zjazdu Biskupów, zobowiązał księży posłów i senatorów do „wspólnego działania w sprawie projektowanych ustaw, dotyczących prawa małżeńskiego"’. W 1926 roku natomiast Episkopat wydał list pasterski, w którym zwrócił uwagę wiernych na niebezpieczeństwa zagrażające małżeństwu katolickiemu. Biskupi wzywali w nim wiernych do pracy nad naprawą rodziny i do obrony praw katolików, a przedstawicieli rządu i stronnictw poselskich prosili o obronę sakramentalnego charakteru małżeństw katolickich ${ }^{8}$.

\footnotetext{
${ }^{6}$ O małżeństwie. List pasterski do duchowieństwa i wiernych, w: J. Bilczewski, Listy pasterskie, odezwy, kazania i mowy okolicznościowe, t. III, Lwów 1924, s. 344.

7 Cyt. za S. Wilk, Episkopat Kościoła katolickiego w Polsce w latach 1918-1939, Wydawnictwo Salezjańskie, Warszawa 1992, s. 146-147.

8 Por. List pasterski biskupów polskich w obronie sakramentu małżeństwa, „Kronika Diecezji Kujawsko-Kaliskiej” 20(1926), s. 105-106.
} 
Projekt Komisji Kodyfikacyjnej dotarł do opinii publicznej w 1931 roku. Jego główne tezy i wybrane artykuły zostały przedstawione w dniu 25 października (w uroczystość Chrystusa Króla), na posiedzeniu Stałej Delegacji Zrzeszeń i Instytucji Prawniczych, w którym uczestniczyli także przedstawiciele władz państwowych. Episkopat, który już wcześniej zapoznał się z projektem, ale nań nie reagował, sądząc, że nie zostanie opublikowany, podjął energiczne przeciwdziałania. W specjalnym orędziu z 10 listopada 1931 roku biskupi ostrzegli duchowieństwo i wiernych przed przygotowywanym prawem małżeńskim i wezwali katolików, ,aby czynili to wszystko, co ten straszliwy i tak szkodliwy zamiar udaremni"9. Niektórzy biskupi wydali ponadto rozporządzenia, w których dokładniej określili zadania dla duszpasterzy, organizacji katolickich i dla prasy. Charakterystycznym tego przykładem może być zarządzenie kard. Hlonda z 13 listopada 1931 roku. Prymas Polski stwierdził, że „Komisja Kodyfikacyjna ośmieliła się jednak zlekceważyć nasze uczucia religijne, ogłaszając swój nieszczęśliwy projekt drukiem. Do tej chwili trafiały się wprawdzie próby osłabienia ducha Chrystusowego w narodzie, ale były to na ogół ukryte, nieraz starannie maskowane podkopy. Tylko tu i ówdzie trafiały się śmielsze otwarte występy zwolenników nowoczesnego pogaństwa. [...] Tym razem atoli spotykamy się po raz pierwszy z występem instancji urzędowej, która proponuje uregulowanie małżeństwa w sposób równający się jego sponiewieraniu i upadkowi. Rozległ się ten fakt złowrogim echem po kraju, niby odgłos sąsiednich sowietów i jakby zapowiedź walki z wiarą narodu i z Kościołem" ${ }^{10}$. Dlatego polecił w nim m.in., aby na intencję odwrócenia od kraju nieszczęścia zagrażającego mu przez projektowaną ustawę po każdej mszy św. w niedziele i święta śpiewano Pod Twoja obronę, by duszpasterze w szczególny sposób podkreślali uroczystość Świętej Rodziny, aby propagowali wśród wiernych poświęcenie rodzin Sercu Bożemu i by wręczali wszystkim nowożeńcom encyklikę Piusa XI O małżenstwie chrześcijańskim z 31 grudnia 1930 roku. Prymas wezwał także wszystkie organizacje katolickie oraz związki i stowarzyszenia niekościelne, aby na swych zebraniach podjęły rezolucję potępiającą projekt ustawy. Podobne uchwały, w których wierni mieli się domagać poszanowania zasad Chrystusowych w życiu rodzinnym, miały zostać podjęte na wiecach i zebraniach zorganizowanych w uroczystość Niepokalanego Poczęcia NMP, tj. w dniu wyznaczonym przez Episkopat na przeprowadzenie w całym kraju specjal-

9 W sprawie projektu ustawy o małżeństwie. Orędzie Episkopatu Polski, „Miesięcznik Kościelny" 46(1931), s. 208.

10 Tamże, s. 209. 
nych nabożeństw błagalnych. Akcja protestacyjna objęła cały kraj. Wzięły w niej udział nie tylko organizacje kościelne, ale także zawodowe, społeczne, kulturalno-oświatowe, a nawet stronnictwa polityczne ${ }^{11}$. W wielu parafiach akcja ta stała się również okazją do lepszego zapoznania wiernych z nauką Kościoła na temat małżeństwa i rodziny. Ostatecznie projekt Komisji Kodyfikacyjnej nie został wniesiony pod obrady sejmu, ale też nie został przez rząd ostatecznie wycofany. W 1936 roku był on jeszcze przedmiotem obrad Komisji Prawnej Episkopatu, podczas których sprawę kodyfikacji prawa małżeńskiego referował kard. Hlond ${ }^{12}$.

\section{Nauczanie kard. Hlonda}

Prymas Hlond w swoich wystąpieniach zwracał uwagę na to, czym jest rodzina chrześcijańska i jakie są jej zasady. Podczas akademii ku czci Świętej Rodziny w Poznaniu (7 stycznia 1934) powiedział: „Dlatego my dzisiaj zebraliśmy się, aby podkreślić zasady rodziny chrześcijańskiej, podkreślić, że rodzina chrześcijańska, zwłaszcza w pojęciu katolickim, jest boską instytucją, która istnieje nie z łaski kogokolwiekbądź, ale istnieje tylko $\mathrm{z}$ ustanowienia boskiego i od Boga samego ma swoje prawa i nakazy. Małżeństwo chrześcijańskie i rodzina chrześcijańska ma swoje cele przez Stwórcę wyznaczone i tych celów zmieniać i przekreślać nie wolno"13. Już w jednym ze swoich pierwszych artykułów: O chrześcijańskim duchu w rodzinie, opublikowanym na łamach „Wiadomości Salezjańskich” w 1905 roku, pisał: „Rodzina to fundament, na którym spoczywa dobro społeczeństwa i Kościoła. [...] Chrystus bowiem przyszedł właśnie po to na ziemię, by rodzinę, która wskutek obyczajów pogańskich stoczyła się w przepaść moralnego upadku, podźwignąć, podnieść, udoskonalić. $\mathrm{W}$ tym celu uświęcił

\footnotetext{
11 W samych tylko archidiecezjach gnieźnieńskiej i poznańskiej protesty przeciw projektowi podpisało 6891 organizacji z terenu 508 parafii i z ogólną liczbą 969115 członków, w tym 1631 stowarzyszeń Akcji Katolickiej, 2260 stowarzyszeń kościelnych, 2000 stowarzyszeń świeckich. Por. „Miesięcznik Kościelny” 47(1932), s. 38.

12 Szerzej na temat kodyfikacji prawa małżeńskiego zob. S. Wilk, Episkopat Kościoła katolickiego w Polsce, dz. cyt., s. 144-150.

13 Przemówienie na akademii ku czci św. Rodziny, w: August kard. Hlond, Dzieła. Nauczanie 1897-1948, t. I, red. J. Konieczny TChr, Oficyna Wydawnicza Kucharski, Toruń 2003, s. 407 [dalej: A. Hlond, Dzieła].
} 
ją przez ustanowienie Sakramentu małżeństwa i pragnie, by rodzina była świętą, by świętymi byli jej członkowie, świętym jej życie"14.

Po drugiej wojnie światowej, apelując o obronę rodziny przed błędnymi systemami filozoficznymi i etyką laicką, stwierdził: „Rodzina należy do tych wartości, których bez świętokradztwa tykać nie wolno. Jak społeczne i polityczne przemiany nie mają pogrązać człowieka, lecz podnosić na wyższe szczeble bytu i kultury, tak reformy życia nie powinny przekreślać rodziny, lecz chronić ją i popierać. Rodziny nie należy spychać na ofiarę przewrotu. To też i w obecnym okresie demokratyzacja form życiowych nie może być pretekstem do ataków na rodzinę. [...] Tak zw. liberalnego ujmowania problemu rodziny przyjąc nie możemy - i wbrew liberalizmowi stoimy niewzruszenie na stanowisku, że nie wolno poniżać rodziny do zakładu przyjemności, stojącego poza etyką i odpowiedzialnością. Rodzina nie jest stadłem faunów leśnych, nie jest beztroską majówką rozbawionych smakoszów zabawy, nie jest spółką rozrywkową obliczoną na maksimum przyjemności, a minimum obowiązków. Rodzina polska musi się utrzymać na poziomie zasad chrześcijańskich, zachować swój honor etyczny i mieć chrześcijańską świadomość swych zadań"15. Przestrzegał także przed nadużywaniem wolności i praw indywidualnych, które „o ile przekreślają rodzinę, są nadużyciem, fikcją, nieporozumieniem; zasada wolności indywiduum musi się skonkretyzować w ramach społeczności, a przede wszystkim w prawie rodziny, która daje osobie rozwój fizyczny i duchowy, a zarazem zakreśla granice prawdziwej wolności ludzkiej. Wolność przeciw rodzinie i jej istocie i dobru jest wywrotem"16.

Prymas Polski podkreślał funkcję wspólnotową rodziny, „która powinna wyrastać z ofiarnej miłości i z determinacji moralnej" ${ }^{17}$. Dom rodzinny powinien być gościnnym, pracowitym, społecznym ośrodkiem ducha, świątynią kultury, a nie miejscem bezczynności, zasypiania w wygodach, spokoju. Rodzina jest społecznością, w której panuje ład wewnętrzny, hierarchia ojcowska i matczyna, „to pierwsza władza, do której się młody Polak musi

\footnotetext{
14 O chrześcijańskim duchu w rodzinie, w: A. Hlond, Dzieła, dz. cyt., s. 22.

15 A. Hlond, Dzieła, dz. cyt., s. 813-814.

16 Z notatnika kardynała Augusta Hlonda, opr. ks. W. Necel TChr, Hlondianum, Poznań 1995, s. 395 .

17 Cyt. za: J. Ozdowski, Rodzina w pismach kardynała Augusta Hlonda, „Chrześcijanin w świecie" 11(1979)10, s. 44.
} 
przyzwyczaić, dom bez hierarchii jest szkodnikiem w państwie"18. Zalecał przezwyciężanie konfliktów wewnętrznych, likwidowanie sporów, ustępstwa, ale jednocześnie zwalczanie egoizmu oraz samolubnej wygody. W liście pasterskim $O$ ducha chrześcijańskiego w Polsce, nawołując do świadomego i odpowiedzialnego rodzicielstwa, pisał m.in.: „Dla nas katolików małżeństwo jest sakramentem i instytucją, będącą na służbie twórczej Opatrzności. Rodzina jest dla nas świętością, której hańbić nie wolno. Rodzina nie jest domem zabawy i uciechy, lecz powołaniem do obowiązku, do wzniosłej misji, do ofiary $i$ trudu. Dziecko nie jest ciężarem i kłopotem, lecz radosnym dopełnieniem sakramentalnej jedności małżeństwa, uwiecznieniem się ojca i matki w obrazie Bożym i dziejowym odradzaniem się narodu i ludzkości"19.

Kard. Hlond często podkreślał, że rodzina powinna być ośrodkiem świętości. W 1924 roku w liście pasterskim O życie katolickie na Śląsku, pisząc o konieczności odrodzenia życia katolickiego, stwierdzał, że to odrodzenie powinno „wnieść pierwiastek nadprzyrodzony, aby się z mieszkania rodzinnego stała rodzinna świątynia, a $\mathrm{z}$ ogniska domowego domowy ołtarz, a z ojca rodziny kapłan, z matki anioł, z dziatwy zaś świeże a silne pędy na drzewie Kościoła i narodu. Odrodzenie odnowi tu wiarę i miłość, wzmocni jedność, ugruntuje święty obyczaj i wychowanie dzieci w bojaźni Bożej. Rodzina katolicka musi odżyć jako zdrowa i pełna życia komórka religijna i społeczna"20. O religijnych podstawach życia rodzinnego mówił także w Poznaniu w 1946 r.: „Mąż nie jest tyranem, lecz miłującą i odpowiedzialną głową rodziny. Ojcostwo jest posłannictwem i nakłada święte obowiązki. Żona nie jest sługą, lecz towarzyszką życia na równych prawach. Macierzyństwo pojęte jako powołanie, pełnia życia i chluba. Dzieci są ośrodkiem zainteresowań rodziców, źrenicą ich oka i przedmiotem wspólnego poświęcenia; będą spadkobiercami imienia, honoru, materialnej i duchowej spuścizny domu. Rodzina chrześcijańska jest przybytkiem wiary, szkołą cnoty, strażnicą obywatelskich uczuć, świątynią miłości i ofiary. A nietykalną zasadą etyczną rodziny chrześcijańskiej jest święte prawo Boże. [...] Przez wyniesienie małżeństwa do godności sakramentu, Zbawiciel otwiera rodzinie dostęp do mistycznych źródeł Łaski i wiąże ją z Kościołem, uświęcając swym błogosławieństwem wspólne pożycie, wspólne zadania, wspólne radości i troski”21.

\footnotetext{
18 Z notatnika, dz. cyt., s. 392.

19 August kard. Hlond, Z Prymasowskiej Stolicy. Listy Pasterskie, Poznań 1936, s. 133.

20 Tenże, Na straży sumienia narodu. Wybór pism i przemówień, przedmowa prof. O. Haleckiego, wyd. ks. A. Słomka SDB, Ramsey 1951, s. 29.
}

${ }^{21}$ A. Hlond, Dzieła, dz. cyt., s. 811, 813. 
W innych licznych wypowiedziach prymas Polski głosił nadrzędną wartość rodziny, odkupionej śmiercią Chrystusa. Istotę rodziny upatrywał we wspólnocie miłości, a w życiu rodzinnym - apostolski charakter. „Rodziny chrześcijańskie utrzymują ducha chrześcijańskiego w parafii, w mieście, w kraju. Rodziny te są niejako placówkami Kościoła, gdzie wzrastają prawdziwe jego dzieci i dobrzy obywatele; one są tą rolą urodzajną, gdzie się rodzą i rozwijają jego wybrańcy, one są szlachetnymi szkółkami, skąd wychodzą kapłani, zakonnicy, zakonnice i dziewice"22. W nauczaniu Hlonda interesujące są również aspekty polityki rodzinnej. „Trzeba ratować rodzinę pod względem gospodarczym. Powojenne warunki nakładają wielu rodzinom ciężary nie do wytrzymania. Dokonujące się reformy ekonomiczne i społeczne nie powinny pomijać rodziny, zwłaszcza, gdy chodzi o politykę płac, o system podatkowy, prawo spadkowe, zagadnienie mieszkaniowe, reformę rolną, osadnictwo"23.

W rodzinie mogą być realizowane cele wychowania chrześcijańskiego: prawidłowy rozwój fizyczny, umysłowy i moralny dzieci, wykształcenie w wierze, usposobienie do życia chrześcijańskiego. „Rodzina wychowuje do ofiary, do sił moralnych, do odpowiedzialności"24. W dziedzinie wychowania młodego pokolenia rodzina, Kościół i państwo winny ze sobą współpracować i uzupełniać się. Już w 1905 r. stwierdzał, że „przyszłość katolicyzmu zależy od wychowania szkolnego", ale dodawał jednocześnie, iż „doświadczenie uczy, że zasady nawet najlepsze, wszczepione w szkole, często nie wydają pomyślnych wyników, bo stają im na przeszkodzie złe wpływy domowe"25. Zwracał też uwagę na atmosferę domu rodzinnego, a przede wszystkim na ważność świadectwa starszego pokolenia: „Źle, gdy dzieci czują w domu moralną próżnię, gdy ich tam tylko konwenans i fason obliguje; gorzej, gdy patrzą na zgorszenie rodziców.... gdy się duszą zatrutą atmosferą moralną"26.

Podawał trafną diagnozę zagrożeń współczesnej rodziny, zwracając uwagę na błędne poglądy dotyczące istoty rodziny, które lekceważyły jej wielką doniosłość społeczno-moralną. Postulował, aby problemów rodziny „nie rozwiązywać w oparciu o mrzonki doktrynalne, lecz w świetle

\footnotetext{
22 Cyt. za: J. Ozdowski, Rodzina..., dz. cyt., s. 47.

23 A. Hlond, Dzieła, dz. cyt., s. 814.

24 Z notatnika, dz. cyt., s. 385

25 A. Hlond, Dzieła, dz. cyt., s. 22.

26 Z notatnika, dz. cyt., s. 393.
} 
realizmu, trzeźwego osądu i sumienia, z uwzględnieniem dobra państwa"27. Ostrzegał przed negatywnymi skutkami rozwodów, które były objawem dekadencji moralnej, osłabiającej naród i państwo. Odwołując się do przykładu Francji, gdzie rozwody wprowadzono w 1884 roku, stwierdzał: „rozwody niczego nie naprawiły; nie umoralniły literatury francuskiej; nie usunęły, a nawet nie zmniejszyły dramatów małżeńskich; nie uzdrowiły życia, lecz pogorszyły i pogarszają do dziś dnia"28. Wśród przyczyn kryzysu rodziny wymieniał także niewierność małżeńską, unikanie potomstwa, zabijanie nienarodzonych, negowanie świętości i posłannictwa rodziny. Ubolewał nad tym, że „uczciwość, prawość i wierność ustępują przed kłamstwem, krętactwem i podłością" ${ }^{29}$. Jego zdaniem, negatywny wpływ na życie rodzinne wywierały trudne warunki mieszkaniowe, nadmierna ruchliwość społeczna i bezrobocie.

Zdaniem kard. Hlonda, polityka rodzinna powinna zabezpieczać warunki prawne, społeczne i zdrowotne rozwoju rodzin. Dla rozwoju rodziny niezwykle ważną sprawą było właściwe ustawodawstwo małżeńskie i rodzinne, zgodne z zasadami moralnymi. Apelował do władz państwowych, aby w polityce społecznej kierowały się szacunkiem dla małżeństwa i czcią dla rodziny, organizując poradnictwo rodzinne i prowadząc właściwą politykę płac. Ostrzegał przed zagrożeniami stwarzanymi rodzinie przez wielkie aglomeracje miejskie i przemysłowe. „Nie dopuścimy, by wielkie miasta i zagłębia przemysłowe rozbijały rodziny. Musi tam być miejsce dla dzieci i dla starców. Musi tam być ciepło rodzinne i rodzinna radość. Bezduszne szeregi domów i ulic, bezduszne maszyny, cement i beton, kamień i asfalt - nie dadzą człowiekowi szczęścia, jeżeli przy ognisku domowym nie znajdzie w atmosferze rodzinnej tchnienia ludzkiego. Technika i sport nie mogą likwidować domu i rodziny" ${ }^{30}$. Dom polski był mu szczególnie drogi. Powinien być najwierniejszym stróżem „zdrowych tradycji, zasad moralnych, cnót rodzinnych, autorytetu rodziców, wiary, patriotyzmu [...] wiele kwiatów, solidny, tynkowany, o pięknych formach, wesoły, wstawiony w zieleń ogrodów, czysty [...], może być biedny, ale musi być czysty"31.

\footnotetext{
${ }^{27}$ Cyt. za: J. Ozdowski, Rodzina..., dz. cyt., s. 43.

28 Z notatnika, dz. cyt., s. 397.

29 Cyt. za J. Ozdowski, Rodzina..., dz. cyt., 44.

${ }^{30} \mathrm{Z}$ notatnika, dz. cyt., s. 386.

31 Tamże, s. 392.
} 
Z tych bardzo skrótowo przedstawionych wypowiedzi kard. Hlonda na temat małżeństwa i rodziny wynika, że koncentrowały się one wokół ich prawno-naturalnych podstaw, zasadniczych funkcji, sakramentalnego i wspólnotowego charakteru oraz ich miejsca i roli w życiu religijnym poszczególnych osób, a także całego społeczeństwa. Odpowiedzią na zagrożenia powinna być większa troska wiernych o świętość małżeństwa, o pogłębienie życia religijnego i o panowanie ducha chrześcijańskiego w rodzinach. Prekursorski niejednokrotnie charakter tych wypowiedzi i wezwania do aktywnej polityki prorodzinnej wskazują, że „Prymas Polski w wielu swoich wypowiedziach wyprzedzał naukę Soboru Watykańskiego II i współczesne nauczanie społeczne Kościoła katolickiego"32.

32 J. Ozdowski, Rodzina..., dz. cyt., s. 50. 